\title{
Academic Labour, Digital Media and Capitalism
}

Special Issue, edited by Thomas Allmer and Ergin Bulut

tripleC: Communication, Capitalism \& Critique 16 (1), 2018, pp. 44-240

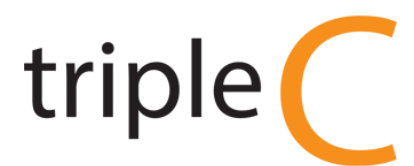

http://www.triple-c.at

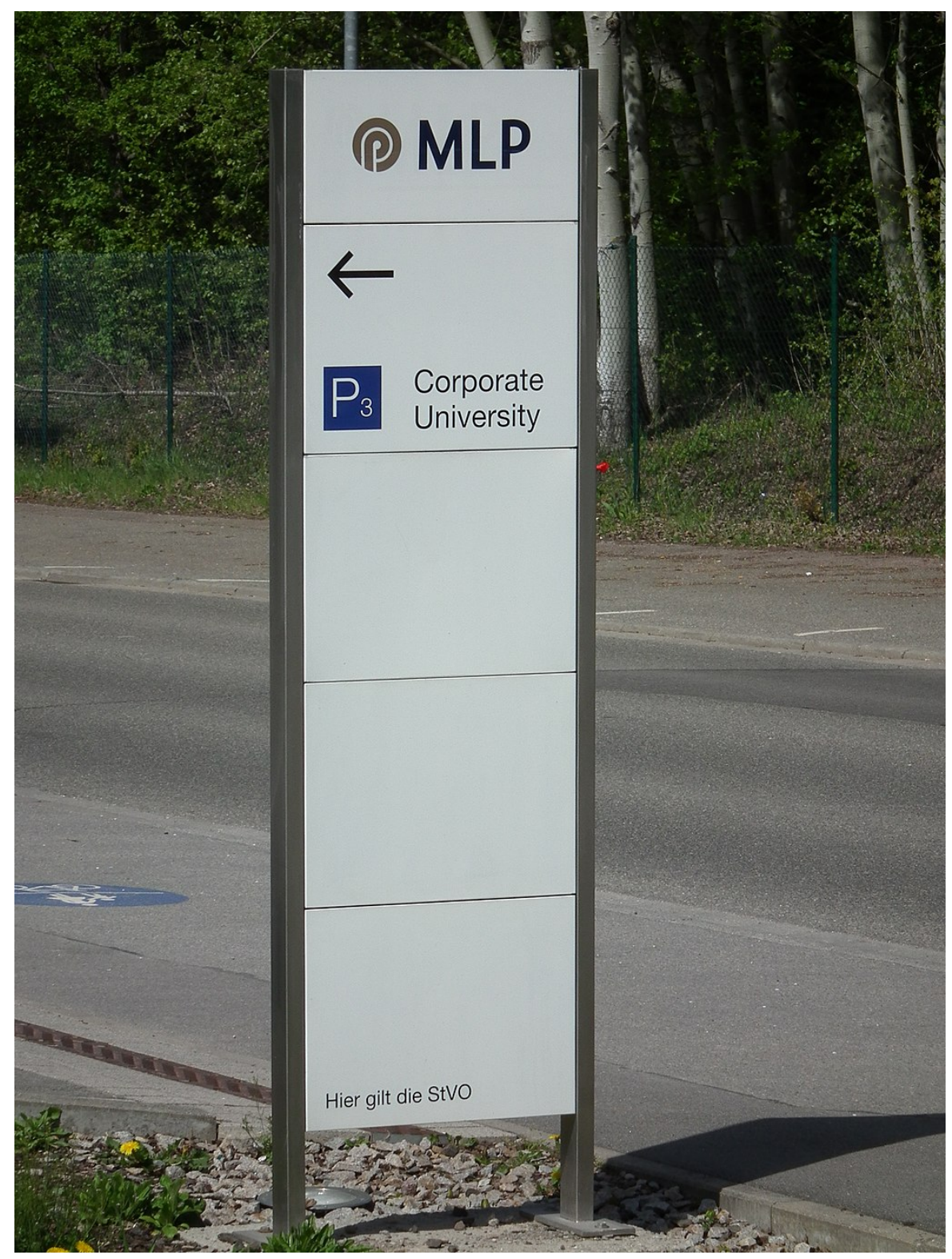





\section{Academic Labour, Digital Media and Capitalism}

Special Issue, edited by Thomas Allmer and Ergin Bulut

tripleC: Communication, Capitalism \& Critique 16 (1), 2018, pp. 44-240

\section{Table of Contents}

Thomas Allmer and Ergin Bulut: Introduction: Academic Labour, Digital Media and Capitalism, pp. 44-48

Thomas Allmer: Theorising and Analysing Academic Labour, pp. 49-77

Maxime Ouellet and Éric Martin: University Transformations and the New Knowledge Production Regime in Informational Capitalism, pp. 78-96

Richard Hall: On the Alienation of Academic Labour and the Possibilities for Mass Intellectuality, pp. 97-113

Marco Briziarelli and Joseph L. Flores: Professing Contradictions:

Knowledge Work and the Neoliberal Condition of Academic Workers, pp. $114-128$

Jamie Woodcock: Digital Labour in the University: Understanding the Transformations of Academic Work in the UK, pp. 129-142

Jan Fernback: Academic/Digital Work: ICTs, Knowledge Capital, and the Question of Educational Quality, pp. 143-158

Christophe Magis: Manual Labour, Intellectual Labour and Digital (Academic) Labour. The Practice/Theory Debate in the Digital Humanities, pp. 159-175

Karen Gregory and sava saheli singh: Anger in Academic Twitter: Sharing, Caring, and Getting Mad Online, pp. 176-193

Andreas Wittel: Higher Education as a Gift and as a Commons, pp. 194-213

Zeena Feldman and Marisol Sandoval: Metric Power and the Academic Self: Neoliberalism, Knowledge and Resistance in the British University, pp. 214-233

Güven Bakırezer, Derya Keskin Demirer and Adem Yeşilyurt: In Pursuit of an Alternative Academy: The Case of Kocaeli Academy for Solidarity (Non-Peer-Reviewed Reflection Article), pp. 234-240 



\title{
Introduction: Academic Labour, Digital Media and Capitalism
}

\author{
Thomas Allmer* and Ergin Bulut**
}

*University of Stirling, Stirling, Scotland, UK, thomas.allmer@stir.ac.uk, http://allmer.uti.at

**Koç University, Istanbul, Turkey, erginb@gmail.com

Modern universities have always been part of and embedded into capitalism in political, economic and cultural terms. In 1971, at the culmination of the Vietnam War, the Chomsky-Foucault debate reminded us of this fact when a student asked: "How can you, with your very courageous attitude towards the war in Vietnam, survive in an institution like MIT, which is known here as one of the great war contractors and intellectual makers of this war?" (Chomsky and Foucault 2006, 63). Chomsky responded dialectically, but also had to admit that the academic institution he is working for is a major organisation of war research and thereby strengthens the political contradictions and inequalities in capitalist societies.

Edward P. Thompson (1970), one of the central figures in the early years of British cultural studies, edited Warwick University Ltd in the 1970s. Thompson was working at the University of Warwick then and published together with colleagues and students a manuscript that discovered, as the title suggests, the close relationship of their university with industrial capitalism. The book also revealed some evidence of secret political surveillance of staff and students by the university, which was uncovered by students occupying the Registry at Warwick at that time.

In a more recent context, the renowned Marxist geographer David Harvey faced an interview question about managerialism and the pressure to raise external funding at his university, City University of New York: "I had a dean saying to me that I wasn't bringing in any money. You're worthless, he said, as far as we're concerned. So I asked what I was supposed to do. Was I supposed to set up an Institute of Marxist Studies funded by General Motors? And the dean said, 'Yes, that's a good idea. I'll support you if you can do that'" (Taylor 2010).

The relationship between state control and global capitalism has intensified in the last decades. With the collapse of the welfare state and the drop of public funds, universities are positioning themselves as active agents of global capital, transforming urban spaces into venues for capital accumulation and competing for profits derived from international student populations. In this environment, students have to pay significant amounts of tuition for precarious futures. Similarly, teaching and research faculty across the globe have to negotiate their roles that are often strictly defined in entrepreneurial terms. Increasingly, the value of academic labour is subject to new forms of control, surveillance and productivity. As the recent cases of Steven Salaita (USA), Academics for Peace (Turkey) and the crackdown against students in India reveal, academic labour and academics in general are also facing immense challenges in terms of state control and freedom of speech.

Situated in this economic and political context, the overall task of this special issue of tripleC: Communication, Capitalism \& Critique is to gather critical contributions examining universities, academic labour, digital media, and capitalism. The articles col- 
lected in this special issue (1) provide the context, history and theoretical concepts underlying academic labour, (2) analyse the relationship between academic work and digital media/new information and communication technologies/the Internet/social media, and (3) discuss the political potentials and challenges within and beyond higher education institutions. The papers cover one or more of the following or related questions.

\section{Contextualising and Theorising Academic Labour}

- What is the historical role of universities and academic labour and how has it changed over time?

- What is the role of universities for capitalist development in the age of neoliberalism and post-Fordism (e.g. employability, market-driven and industrial research)?

- How far can the neoliberal university be considered as medium and outcome of informational capitalism?

- How far can the university expansion be understood as a dialectic development of progress and regress, social achievement and advanced commodification?

- What is meant by concepts such as Warwick University Ltd, McUniversity, academic proletarianisation, edu-factory, Taylorization of higher education, corporate university, academic capitalism, entrepreneurial university, university gamble, digital diploma mills, global university, DIY university, Uberification of the university, gig academia etc. in the context of academic labour? How are these concepts related to the wider social context and the existing capitalist order? How can a systematic typology of the existing literature be constructed?

- What is the role of the concept of value for understanding academic labour?

- What is the role of the concepts of the working class and the proletariat for theorising academic labour?

- How should we define academic labour; who is included/excluded by this understanding? Where does adjunct labour stand?

- What kind of workers are academics and how are they related to knowledge, informational and cultural workers?

- How far can the outcomes of academic labour be considered as part of the information and communication commons?

- To what extent rests informational capitalism on the commons produced at universities?

- What are the important dimensions for constructing a typology of working conditions within higher education (e.g. new managerialism, audit culture, workload, job insecurity)?

- How do different working contexts and conditions in academia shape feelings of autonomy, flexibility and reputation on the one hand and precariousness, overwork and dissatisfaction on the other?

\section{Academic Labour and Digital Media}

- Given that the academic work process is today strongly mediated through digital media, to what extent can academic workers be considered as digital workers, and academic labour as digital labour?

- In what ways can digital education and online distance learning be understood as a new capital accumulation strategy that aims at attracting international students in a commodified and competitive higher education market? 
- In what ways can digital education be regarded as a response to neoliberal conditions within higher education?

- How do digital media/new information and communication technologies/the Internet/social media frame the working conditions of academics?

- How are the working conditions of academics characterised by intensification and extension in the realm of the digital university (e.g. the blurring of working space and other spaces of human life, the blurring of labour and free time, fast academia, always-on cultures, deskilling, casualisation, electronic monitoring, digital surveillance, social media use for self-promotion, new forms of intellectual property rights)?

\section{Politics, Struggles and Alternatives}

- How do the broader political realities and potentials in terms of solidarity, participation and democracy at universities look like?

- What is the relationship between the state and academic labour? What are some of the lessons that we can learn from global crackdowns on academic labour?

- What are the challenges in order to reclaim the university as site of struggle for both academics and students?

- How far can the struggle at universities be connected to the global struggle against capitalism?

- How do the political potentials of alternatives within higher education look like (e.g. informal learning processes, co-operative education, open education, open access, copyleft, creative and digital commons, Wikiversity)?

In his opening piece to the special issue, Thomas Allmer contextualises universities historically within capitalism and analyses academic labour and the deployment of digital media theoretically and critically. Based on a critical social theory approach, he engages with the history and context of universities in informational capitalism, deals with the forms and concepts of academic labour, and provides a systematic analysis of working conditions at higher education institutions. The article outlines the impact of new information and communication technologies on academic labour. Allmer ultimately concludes with a summary, discusses political potentials and provides alternatives.

Based on the critique of value (Wertkritik) and in the context of the structural crisis of capitalism, Maxime Ouellet and Éric Martin scrutinize the transformations at universities and the new knowledge production regime in informational capitalism. In particular, they argue that the post-war expansion of the university should be seen in the context of a capital-labour compromise and the institutionalisation of the American New Deal under Fordist conditions. The authors describe the neoliberal university as an important hub for technological innovation and for the valorisation of capital. In global capitalism, we can now observe a globalised university that remains agile, hyper-reactive and adaptable, transforming academic subjectivity.

Richard Hall's contribution to the special issue asks what alternatives proletarianised universities can produce to counter hopelessness and anxiety derived from academic labour's alienation. For Hall, 'mass intellectuality' and social forms of knowledge can open a path towards "a struggle over the proletarianisation of labour, and its emancipatory implications". As Hall considers various examples of practical responses to the neoliberal reduction of knowledge production to economic value, he especially underlines the significance of community-based solidarity between higher 
education institutions and other social spaces outside the formal boundaries of the university.

With a particular focus on US media and communication departments, Marco Briziarelli and Joseph L. Flores provide an interpretation of the condition of the academic profession and observe a contradictory position of academics in terms of class, value production and subjectivity. The authors reject the idealist notion of academics and place academic work in the context of knowledge work and informational capitalism and thereby provide a general account of the political economy of academic labour. The article offers an analysis of the political economy of academic publishing and teaching and concludes with an argument for initiatives such as Precarious Workers Brigades and Carrot Workers Collective in the UK, Quinto Stato in Italy, and the Cultural Workers Organize in Canada.

Jamie Woodcock investigates the shifts and transformations of the university and the academic labour process in times of neoliberalism and the introduction of new digital technologies. He thereby moves beyond the simple return to a romanticised pre-neoliberal university and studies the subsumption of research and teaching under the imperatives of capital. Based on Marx's idea of the labour process, he analyses the academic labour process and the impact of digitalisation accordingly. With the help of concepts gained from the Operaismo movement, he finally discusses the technical and political composition of academic workers and concludes with political alternatives for a different kind of university.

Jan Fernback takes issue with how the ideology of information society has repurposed universities and professorial labour in the lines of managerialism. Drawing on Michel Foucault's notion of disciplinary power, Fernback demonstrates how practical implementations of ICTs Taylorise and routinise academic work, produce audit cultures, and lead to the virtualisation of higher education institutions through an enterprise ethic. However, Fernback's piece is also invested in resistance. Therefore, she introduces Paolo Freire's work and his notion of 'critical consciousness' in his discussion of various responses to neoliberal logics at work in higher education institutions.

Christophe Magis encourages us to consider how the digital humanities movement can be viewed as offering a critical analysis of the academic system from within the walls of universities, specifically concerning the theory vs. practice debate. Under the fan of "hack" vs. "yack", digital humanists criticise the current academic landscape and its appertaining priority of intellectual labour (yack) over manual work/digital literacy (hack), visible for instance in the reality that digital humanists are seldom offered the tenure track. Ultimately, Magis avers that the academic system should aim at an academic concept of theory and a political concept of practice, a change that would revive the disposition of academia and thus its role in society.

Karen Gregory and sava saheli singh discuss the digital terrain and examine the potentials of 'academic rant' and dissent through two case studies: \#iammargaretmary and the globally contentious case of Steven Salaita. On the one hand, digital media, specifically Twitter, have given us platforms through which academic labour is promoted echoing the media celebrity culture. On the other hand, Gregory and singh make a case for how Twitter as a platform for rant and similar negative emotions can affectively form spaces for collective action and professional support for each other as formal mechanisms for solidarity erode.

Focusing on the educational aspects of academic labour, Andreas Wittel invites us to think about academic labour in relation to gift. For Wittel, despite intense tendencies towards alienation and proletarianisation, gift-giving and social interaction are vital to the practice of education. Wittel ultimately argues that although gift within 
higher education is under attack, a political economy of higher education as commons carries enough potential to rethink the university beyond the neoliberal logics. Despite their relative lack of power, Wittel proposes free and autonomous universities as new spaces for a university system beyond alienated wage labour.

Zeena Feldman and Marisol Sandoval's article is comprised of two parts. The first part explores the metric-driven culture of neoliberal university environment and examines how 'metric power' shapes academic labour. Situating their work within the highly neoliberal higher education system of the UK, the authors then identify a typology of resistance comprised of four pillars: abstention, attack, adaptation and alternatives. The article therefore challenges the accounts regarding lack of resistance against individualised academic labour, but also draws attention to how struggles within the university need to link with struggles within the broader society.

Finally, Güven Bakırezer, Derya Keskin Demirer and Adem Yeşilyurt (reflection, non-peer-reviewed) contribute to the special issue with their concrete experience within and beyond the boundaries of formal university institutions in Turkey. Dismissed from their official positions as dissident academics, Bakirezer, Demirer and Yesilyurt reflect on the pressures of neoliberal authoritarianism on academic labour. In their article, the authors specifically focus on Kocaeli Academy for Solidarity (KODA), founded in September 2016 as a form of resistance to the academic purge in Turkey. As the authors underline almost in a conversational manner with the rest of the special issue, alternative educational spaces have a chance of success only if they are "capable of creating a realistic alternative against the marketized educational system". Through the case study of KODA, this contribution raises important questions about the links between authoritarian politics, freedom of speech, and neoliberalism.

\section{References}

Chomsky, Noam and Michel Foucault. 2006. Human Nature: Justice vs. Power (1971): A Debate between Noam Chomsky and Michel Foucault. In The Chomsky-Foucault Debate: On Human Nature, edited by Noam Chomsky and Michel Foucault, 1-67. New York: New Press.

Taylor, Laurie. 2010. Of Human Greed: Laurie Taylor Interviews David Harvey. New Humanist, June 29. Accessed 26 January 2018. https://newhumanist.org.uk/articles/2325/ofhuman-greed-laurie-taylor-interviews-david-harvey

Thompson, Edward, ed. 1970. Warwick University Ltd. London: Penguin Books.

\section{About the Authors}

\section{Thomas Allmer}

Thomas Allmer is Lecturer in Digital Media at the University of Stirling, Scotland, UK, and a member of the Unified Theory of Information Research Group, Austria. His publications include Towards a Critical Theory of Surveillance in Informational Capitalism (Peter Lang, 2012) and Critical Theory and Social Media: Between Emancipation and Commodification (Routledge, 2015). For further information, please see: http://allmer.uti.at

\section{Ergin Bulut}

Ergin Bulut is Assistant Professor of Media and Visual Arts in Istanbul. His research interests include political economy of media, digital media and politics, and media labor. Together with Michael A. Peters, he edited Cognitive Capitalism, Education and Digital Labor (Peter Lang, 2011). His work has been published in International Journal of Communication, TV \& New Media, Critical Studies in Media Communication, Communication and Critical/Cultural Studies, Media, Culture and Society, and Journal of Communication Inquiry. 


\title{
Theorising and Analysing Academic Labour
}

\author{
Thomas Allmer \\ University of Stirling, Stirling, Scotland, UK, thomas.allmer@stir.ac.uk, \\ http://allmer.uti.at
}

\begin{abstract}
The aim of this article is to contextualise universities historically within capitalism and to analyse academic labour and the deployment of digital media theoretically and critically. It argues that the post-war expansion of the university can be considered as medium and outcome of informational capitalism and as a dialectical development of social achievement and advanced commodification. The article strives to identify the class position of academic workers, introduces the distinction between academic work and labour, discusses the connection between academic, information and cultural work, and suggests a broad definition of university labour. It presents a theoretical model of working conditions that helps to systematically analyse the academic labour process and to provide an overview of working conditions at universities. The paper furthermore argues for the need to consider the development of education technologies as a dialectics of continuity and discontinuity, discusses the changing nature of the forces and relations of production, and the impact on the working conditions of academics in the digital university. Based on Erik Olin Wright's inclusive approach of social transformation, the article concludes with the need to bring together anarchist, social democratic and revolutionary strategies for establishing a socialist university in a commons-based information society.
\end{abstract}

Keywords: Critical Social Theory, Academic Labour, Digital Media, Universities, Knowledge Workers, Digital Labour, Informational Capitalism, Working Conditions, Struggles

Acknowledgement: A shorter version of this article has been published in Critical Sociology: OnlineFirst, 2017. https://doi.org/10.1177/0896920517735669

Universities are often seen as intellectual spaces and communities of scholars, rather than workplaces. At least historically, university lecturers and professors have been considered as being engaged in a higher vocation, similar to writing poetry (Harvie $2006,9)$. The activities of academics have been understood as a high mission, rather than labour, and academics as citizens, rather than workers. This argument is often used to dismiss the political concerns of academic workers (Gulli 2009, 15).

Academic labour studies is an interdisciplinary field in the intersection of subject areas such as education, management, policy studies, cultural studies and sociology. The field is constantly growing, reflected in an expanding literature reporting about the changes in the working conditions of academics. One of the aims of academic labour studies is to bring down university work from its high mission.

However, Winn $(2015,4,10)$ argues that the academic labour studies literature tends to be essayistic in style, hardly engaging on a theoretical level, but criticising neoliberal developments, romanticising the 'golden age' of universities and wanting to restore Fordist configurations. This article strives to move beyond this critique by focusing on a critical social theory approach, contextualising universities historically within capitalism and analysing academic labour theoretically. 
While teaching and research at universities becomes more virtual and digital (for example: online research and digital methods, virtual learning environments, Massive Open Online Courses), several authors (Noble 1998; Gregg 2013; Lupton 2014; Poritz and Rees 2017) have suggested that the deployment of digital media has an impact on the working conditions of academics; to name but a few, the blurring of working space and other spaces of human life, always on cultures, and digital surveillance.

Therefore, this paper focuses on the following areas by moving from the abstract to the concrete level:

- Historical context: universities and academic labour

- Academic labour: theoretical analysis of forms, concepts and conditions

- Digital media: impacts on universities and academic labour

I address these points based on a critical social theory approach. In doing so, I engage with the history and context of universities in the next section. Section two deals with the forms and concepts of academic labour and provides a systematic analysis of working conditions at higher education institutions. The impact of new information and communication technologies on academic labour is outlined in section three. The article concludes with a summary and discusses political potentials and alternatives. While occasional references are made to other areas such as the US and Continental Europe, this article mainly focuses on the UK.

\section{Historical Context: Universities and Academic Labour in Informational Capi- talism}

Older universities such as the ones in Oxford and Cambridge had been founded before the modern British state was created. Considered historically, British universities have been understood as communities of scholars pursuing knowledge and advancing learning. The medieval idea was that academics should organise themselves, where collegiality plays an important role (Callinicos 2006, 21). This idea is still reflected in their current legal form and so most of them are today independent corporate institutions with charitable status. British universities are not state organisations as they are in many other European countries such as Germany and Italy. Nor can their employees be considered as civil servants. Since UK universities were legally never state organisations, but rather independent, care must be taken in using the term 'privatisation', although the UK government has recently implemented new legislations that provides universities the freedom to change their corporate form in order to better access private investment (McGettigan 2013, 128). Outsourcing several tasks and creating joint ventures with the private sector are further strategies of universities to undermine their charity status (for further information on this, see: McGettigan 2013, 128).

The higher education landscape has changed in the last decades. One of the most obvious changes is the expansion in terms of providers, student population and university staff in absolute numbers. Considering Scotland as an example, 232,570 (part- and full-time, under- and postgraduate, national and international) students were enrolled in the academic year 2014/2015. In contrast, 223,530 people studied in Scotland in 2006/2007 and 163,519 people in 1996/1997. This is an increase of 36.7 per cent from 1996 to 2006 and a further increase of 4.0 per cent from 2006 to 2014 . One of the main drivers of this expansion is the internationalisation of the higher education sector. 50,015 international students (other European Union and non- 
European Union students) study at one of the 19 higher education institutions in Scotland. Considering the postgraduates separately, 40.7 per cent of the students come from outside the UK. 19,250 (part- and full-time) academics, 10,515 academic atypical staff and 23,650 non-academic staff are employed at Scottish universities. Almost two-thirds (64.9 per cent) of them work in the major cities Edinburgh and Glasgow (all data for the academic year 2014/2015: Higher Education Statistics Agency 2016).

One of the crucial questions is how to assess the expansion of the universities. According to Callinicos $(2006,5)$, there are two main competing ways of interpretation:

1. One way might be to criticise those developments based on the argument that an expansion of the university necessarily brings down the quality of higher education. The expansion leads to quantity instead of quality, worsened staff-student ratio and a devaluation of the university degree in general. This line of argument is often accompanied with the idea that universities should remain a privilege of a minority being educated at elite universities. This position considers the expansion of universities as a negative development and is traditionally linked to conservative politics.

Indeed, the staff-student ratio has decreased (Higher Education Statistics Agency 2016) and the workload and time pressure for academic staff have increased (University and College Union 2016a, 18-19) in the last decades that might also have a harmful effect on the quality of research and teaching at universities in the UK. But the question remains if these developments are necessarily an outcome of the expansion of universities or rather its political and economic conditions. One could imagine expanding higher education with the provision of the necessary resources and thereby promoting real social inclusion. The critique on the vanishing quality of higher education entails some true elements, but it remains fragile in the analysis of the causes and the suggested solutions. Romanticising the past, arguing for higher education as a privilege for the few and defending elite universities remains a deeply conservative and reactionary ideology.

2. Another position might be that the expansion of the university widens access for people from poorer backgrounds, women and ethnic minorities and thereby provides inclusion, equality of opportunities and social justice. Education is considered as a route out of poverty and disadvantage and to build a more socially just society. Traditionally linked to labour politics, the expansion of the university is rather considered as a positive development.

The expansion of the university and the widening of its access for students and academics from poorer backgrounds, women and ethnic minorities can be considered as an important achievement and social advancement of the last century and was partly the outcome of class struggles, women movements and civil right movements (DyerWitheford 2005, 80). In addition, the expansion of higher education also led to a broader politicisation across social strata and resulted in student movements at several advanced industrialised societies such as Germany and France in the late 1960s. These developments can be considered to be on the subjective level, because human actors, agencies and social groups stood up, raised their voice and 
fought in order to change university structures and society to the better. It is the impact of humans on society.

Capitalism has changed from a Fordist to a post-Fordist accumulation regime and from a Keynesian to a neoliberal mode of regulation (Jessop 2002). Even more than Fordism, informational capitalism requires and rests on trained and skilled workers such as managers, technocrats and scientists being able to plan, manage and operate the sophisticated production process. The expanded university provides such a workforce by being an ideal place for employability and to train workers for the postFordist market (Dyer-Witheford 2005, 71). The neoliberal university provides the workforce for corporations at no costs as higher education is funded by the state and/or paid individually through tuition fees. Capital thereby expropriates the commons.

Besides the tight subordination of teaching to economic needs, research has been changing in the post-Fordist area as well. Much more research is necessary since the spheres of production, circulation and consumption have become more complex. While bigger companies tended to have their own research laboratories, the postFordist accumulation regime requires research at a scale that urges companies to outsource research to universities in order to reduce costs (Callinicos 2006, 13). New joint ventures between universities and the private sector have emerged to the logic of international competition and profit. The costs and risks of research have thereby been socialised, while the benefits of innovation privatised (Dyer-Witheford 2005, 76; Noble 1998). Because of the changing nature of both teaching and research in the neoliberal era, Dyer-Witheford $(2005,76)$ claims that 'capital becomes more intellectual; universities become more industrial'. Academic research has become crucial for post-Fordist accumulation (Dyer-Witheford 2011, 279).

In summary, the post-war expansion of the university can be considered as medium and outcome of the informational capitalism. While research laboratories contributed to bring forward information technologies and techno-scientific innovations that helped to develop a knowledge-based economy (medium), informational capitalism requires a highly trained and skilled workforce being provided by the neoliberal university (outcome).

As part of the neoliberal project, the state has gradually pulled back and a radical privatisation, liberalisation and deregulation of the market have been pushed forward in order to stay internationally competitive. It was primarily the neoliberal ideology of Margaret Thatcher era in the UK and Ronald Reagon epoch in US in the 1980s, starting a process of massive cuts in social services and a reduction in tax for business and simultaneously providing subsidies, which had an enormous impact on working conditions including the introduction of flexible working hours, lowering wage level, increased workloads, less job security, etc. These developments have not only been taken place in the private sector, but also in public institutions such as universities. With the rise of neoliberalism, a 'new manageralism' (Deem, Hillyard and Reed 2007) was implemented in the public sector, affecting both students and staff at higher education institutions. Today's universities have thus to be considered in the context of capitalism's transition from a Fordist to a post-Fordist accumulation regime and a Keynesian to a neoliberal mode of regulation.

As I argued above, the widened access of universities is the historical success of social struggles by humans on a subjective level. Simultaneously, capitalism rests on the expansion of universities as it requires advanced research and a high skilled workforce under neoliberal and post-Fordist conditions. These developments are objective in contrast, because social structures enable and constrain individual actions. 
In order to answer the question if the expansion of the university can be considered as a positive development that promotes social justice, one has to take into account not only the subjective, but also the objective level and the neoliberal and postFordist context. In principal, capital does not mind about the social background of people, as long as they conduct valuable research and can be exploited as trained and skilled workforce. 'The impassable limit of campus identity politics is marked by its recuperation to cognitive capital's drive for a wider recruitment of social intelligence. An official academic credo of multiculturalism and gender-equity opens the way to more comprehensive and efficient commodification of intellectual labourpower.' (Dyer-Witheford 2005, 80) The expansion of the university is neither positive, nor negative, but a contradictory development by widening access for both subordinate groups and capital's interests. In analogy to Horkheimer and Adorno's (1969) understanding of the enlightenment as a dialectic process of progress and regress, liberty and barbarism, the university expansion can also be understood as a dialectic development of progress and regress, social achievement and advanced commodification.

Because the two main competing ways of interpreting the expansion of the university are flawed, a third option is introduced here:

3. Terranova (2004) argues that 'the debate seems to be stuck in the false opposition between the static, sheltered ivory tower and the dynamic, democratic market'. As a result, we need a socialist expansion of the university that provides the necessary material resources in order to ensure teaching and research at a high quality on the one hand and a political and economic context in order to widen access to education in general and higher education in particular for all social groups without interferences of capital's interests of cheap labour power and industrial research on the other. 'Our understanding of the mode of knowledge production in higher education and its conceived role and purpose in public life over the last century must start from a categorical understanding of capitalism and the historical mode of production that reproduces the university'. (Winn 2015, 11) The struggle for better universities can thus not be separated from the struggles against capitalism (Callinicos 2006, 7; Gulli 2009).

\section{Academic Labour}

In the following, I deal with the forms and concepts of academic labour, before a systematic analysis of the working conditions at universities is provided.

\subsection{Forms and Concepts of Academic Labour}

The discussion about academic labour brings up the question if academic workers are part of the proletariat, create value and are exploited in capitalist societies. These questions are important theoretical ones in order to be able to situate academics in a class concept appropriately. Identifying the class position of academic workers is important for political reasons: to create relationships and solidarities and to understand class struggles.

In the introduction to the English version of 'Capital: Volume Two', Mandel argues that Marx used a broad concept of the proletariat that includes all workers who have to sell their labour power. 'The defining structural characteristic of the proletariat in Marx's analysis of capitalism is the socio-economic compulsion to sell one's labourpower. Included in the proletariat, then, are not only manual industrial workers, but all unproductive wage-labourers who are subject to the same fundamental constraints: 
non-ownership of means of production; lack of direct access to the means of livelihood [...]; insufficient money to purchase the means of livelihood without more or less continuous sale of labour-power.' (Mandel 1992, 47) If we accept such a broad understanding and reject the narrow definition of the proletariat as constituted only of productive workers, academics can be considered as part of the proletariat, independently if they create value and are productive or unproductive labourers.

In order to answer the question of value creation and exploitation of academics, it makes sense to have a look at how state theorists analyse the role of public organisations and civil service employees in general. In reference to Yaffe and Offe, Wright $(1978,155-156)$ argues that 'state production is itself not production for the market and thus the state does not accumulate capital out of any realized profits from its own production. Most state expenditure therefore do not directly produce surplus value'. In 'Class Counts', he furthermore claims that state employees' 'wages are largely paid out of taxes, and thus they have a different relationship to private profits and public taxation than employees of capitalist firms' (Wright 1997, 462). If we follow this line of reasoning, one can say that in comparison to workers in other sectors such as engineers in a private company, academics are normally not employed and therefore not directly exploited by capitalists. Many academics are employed by the state or a charity not producing profit and thus cannot be regarded as capitalist enterprises. For schools, which are in this context comparable to universities, Harris $(1982,57)$ argues that teachers 'are employed by the State and they are paid out of revenue they are therefore unproductive labourers'. Teachers are 'outside of the valorisation process, and they do not directly produce surplus value' (Ibid., 128). At universities, there is no such a relationship between workers on the one hand and an owner of productive forces (i.e. capitalist) on the other. Operations such as investing in the stock market, creating joint ventures with the private sector, outsourcing several tasks, minimizing democratic structures, implementing new management methods, etc. let appear higher education institutions very similar to private companies, but the main difference is that universities are owned by the public and not individuals. The property relations between private companies and universities differ.

Marx describes land and nature as the objects of labour, but one can argue that information and knowledge might also serve as objects of labour in the mode of production. Marx himself draws this possibility in the 'Grundrisse'. The technological development of the productive forces causes a rising importance of science, information and general social knowledge in the capitalist process of production. Knowledge becomes a direct force of production. In this context, Marx (1997) has raised the notion of the 'general intellect'.

It can be stated that capitalism has now reached a stage that Marx only claimed as a possibility, a knowledge-based economy depending on the brains of human beings and the social intellect (Dyer-Witheford 2005, 73; Bulut 2011, 161). The brain has become an important productive force in informational capitalism (Fuchs 2008, 200). The last decades of capitalist production have been characterised by an intensification and extension of informational commodities being based on knowledge, ideas, communication, relationships, emotional artefacts, cultural content etc. That is to say, labour is not only based on information, but information and communication are now direct forms of labour. Different types of work include agricultural, industrial and informational labour (Fuchs and Sevignani 2013, 257). Part of this information and knowledge is created and shared by academics at higher education institutions. Universities thus play an important role in informational capitalism. 
Autonomist Marxism has raised the concept of the 'common'. The germ form (Keimform) of capitalism is the commodity and the germ form of communism is the common (Dyer-Witheford 2007, 81; Hardt and Negri 2009, 273). A commodity is a good produced for exchange and a common is a good produced by collectivities to be shared with all. The common is the dialectical sublation of private property and public goods.

The capitalist logic has a very contradictory relationship to the common, because it needs and opposes it at the same time (Sandoval 2014, 234). Capital rests on the common and cannot survive without it as well as permanently tries to expropriate and commodify the commons. The commons are produced and reproduced by all, but only appropriated by capital in order to achieve profit. Capitalist accumulation and development paradoxically require and even make possible the expansion of the common and simultaneously tend to destroy it (Hardt and Negri 2009, 153). The capitalist logic is based on collective production and productive subjectivities and depends ever more on the common due to an increased importance of information, communication, knowledge, and creativity for capitalist production. The capitalist command again and again privatises economic, political, cultural, natural, and technological commons and strives to transform them into private properties. Hence, current capitalist accumulation expropriates and destroys the commons.

One can argue that knowledge and skills that are created and shared at universities are part of the commons. Academic knowledge creation can be considered as a social process. Academics create knowledge that is based on preceding knowledge of society, share this outcomes with society so that further knowledge can be created in society, and so on. Academic knowledge creation is the result of a common social process and an infinite social cycle. Students are also involved in producing the knowledge commons, since teaching is not a one-way process. The interaction between lecturer und students can be considered as production and reproduction of educational knowledge. Informational capitalism rests on the knowledge commons that are partly created at universities. On the one hand, capital needs the knowledge as outcome of academic research for pushing innovation forward, on the other hand, capital requires a highly skilled workforce that has been trained in higher education institutions.

Because universities are primarily funded by the state and through tuition fees, capital receives the knowledge commons at no costs. Capital appropriates the commons and thereby exploits the results of the societal production process at universities. Capital exploits the commons and society. The implementation of patents and intellectual property rights are attempts to transform scientific knowledge and academic commons into private properties. Although academic workers and students are not under direct command of capital, they are part of the knowledge workforce producing the commons that are consumed by capital. Academic labour is thus indirectly producing surplus value and exploited by capital. Academic workers and students can be considered as part of what Hardt and Negri (2004) call the 'multitude'. The multitude is an expanded class concept going beyond manual wage labour and taking into account that labour is increasingly based on the commons.

Capital's consumption of the education commons is not an automatic, allencompassing process. It also leaves space for niches of critical, counter-hegemonic teaching and learning that does not serve capital's interests and cannot be subsumed under capitalism. This form of academic labour is unproductive and does not create surplus value. Although critical research and teaching is tolerated to a certain extent (and tends to be higher at environments where the idea of the neoliberal idea 
is less advanced), it reaches limitations and constraints since students need vocational training and employability skills for the job market. In addition, institutions and departments being in the tradition of critical, non-valuable education are often confronted with financial problems, redundancies or even closures. Taken globally, this form of education tends to be marginalised and (higher) education clearly serves the interests of capital (Harris 1982, 70). Besides the dimension of commodity critique and academic labour, there is also an ideological level of higher education and universities.

The labour process is a human activity where, with the help of the instruments of labour, and alteration of material is effected. Marx understands the labour process as a relationship of human activity with its physical and intellectual capabilities and the means of production with its instruments and subjects of labour. The productive forces are a system of living labour forces and facts and factors of the process of production that cause and influence labour (Leisewitz 1990, 939). There is a relationship between labouring human actors (subject) and means of production (object) that changes historically and is based on a concrete formation of society such as capitalism. On the one hand, subjective productive forces are the unity of physical and spiritual labour forces of an individual (Marx 1997); that is, physical ability, qualification, knowledge, abilities, experiences, etc. On the other hand, objective productive forces are factors of the process of labour and production that are not related to an individual; that is, objects of labour such as resources and raw materials and instruments of labour including technology.

Similarly, academic work is an activity where academics transform and organise with the help of instruments an object in order to produce an academic outcome. The productive forces are a system of academic workers and facts and factors of the process of production that cause and influence academic labour. The relationship between academics (subject) and means of production (object) forms the productive forces of universities. On the one hand, subjective productive forces are the unity of physical and intellectual abilities of academics. On the other hand, objective productive forces are factors of the process of academic labour; that is, objects of academic labour such as knowledge, skills and practices and instruments of academic labour including libraries, computers, laboratories and equipment. Academics make use of libraries, computers, laboratories and equipment in order to produce knowledge, skills and practices and pass it on to society and students. These are 'the general productive forces of the social brain' (Marx 1997). The process is extinguished in the product and includes research outcomes such as publications and technical innovations and teaching degrees hold by bachelor, master and $\mathrm{PhD}$ graduates.

Fuchs and Sevignani $(2013,239-249)$ remind us of the importance of making a semantic differentiation between work and labour in the English language. Work is a creative and productive activity that produces use values in order to satisfy human needs. Work is a general and anthropological concept common to all societies. Labour in contrast is a concrete form of work that produces value. Labour is a historical form of the organisation of work in class societies. It is a specific historical characteristic of work embedded into class relations. Work is essential and takes place in all societies, labour only takes place in capitalism. Because universities are part of capitalism and academics are embedded into class relations, it thus makes sense to speak about academic labour, instead of academic work (Winn 2015, 1). Academic labour is a specific historical form of academic work.

According to Giddens $(1981,64)$ and Bourdieu $(1977,4)$, social phenomena are characterised by a mutual relationship of social structures and social actors. Social 
structures can be understood as institutionalised relationships that enable and constrain the individual. Social actors can be understood as human individuals that act within and might react on social structures. Social phenomena consist of social structures enabling and constraining social actors that react upon social structures. Academic work is also characterised by a mutual relationship of social structures and social actors; or speaking more specifically, of form and content. The social structure and form of academic work can be understood as the political, economic and cultural context of universities. This includes political power relations, the economic structure and cultural hegemony of academic labour and to see universities as institutions within capitalism. These structures do have an enabling and constraining effect on academics. Structures enable academics in the sense that they make possible work in the first place. For example, universities provide employment contracts and material resources and thereby making possible academic work conducted by individuals. But contracts and resources are limited in many ways and thus also constrain individuals and academic work. The social actors can be understood as human individuals conducting academic work resulting in academic content. This includes the academic as subject creating a certain outcome of academic knowledge, skills and practices, the analysis and assurance of the quality and values of this outcome and the pedagogical impact. Social actors might react on social structures within universities. Social structures are the historical outcome of struggles and thus changeable to a certain extent. For example, salary bargaining, reduced workloads, additional resources, new staff etc. are possible reactions of academics to the social structure within universities. These new social structures again have an effect on individuals. Academic work is thus a permanent process of social structures enabling and constraining individuals that react upon social structures.

Yet, Winn $(2015,1-2)$ argues that there is a tendency within the existing literature to focus on the content of academic practice, values of as well as teaching and assessment in higher education, concerns with identity and what it subjectively means to be an academic. Such a focus is one-sided, undialectical, leaves out the political economy of higher education and critical engagement of capitalism. Bringing back the relationship between the political-economic context and the academic as worker within academic labour studies is the focus of this paper and my on-going research. The distinction between form and content of academic labour is related to the distinction between relations and forces of production. Both the content of academic work and productive forces consider the particular production process and the form of academic work and relations of production take into account the social context of this process. Talking about the content and omitting the form of academic work is similarly as problematic as talking about specific forms of the organisation of the productive forces, cumulated in terms such as 'information society' or 'network society', and omitting questions of the relations of production with regard to ownership, power and division of labour.

As outlined in the previous section, although the university as a place of academic knowledge creation has a long tradition, its development from an intellectual circle of elites to a broader institution of higher education can be considered as medium and outcome of informational capitalism. The realm of academia is a specific subsystem of the information and knowledge sector. Academic work is a specific form of information work that has to do with the production and distribution (reproduction) of academic knowledge, skills and practices. Because culture entails information work creating content and communication, academics can be considered as cultural workers (Gill 2014). In sum, academic work is part of informational work that is part of cultural 
work. 'Artistic and academic traditions extol sacrificial concepts of mental or cultural labour that are increasingly vital to newly important sectors of the knowledge industries' (Ross 2000, 2). The strong relationship between universities and neoliberalism indicates how the spheres of culture and economy are interrelated.

Academic work is linked to other forms of work such as clerical, technical and manual work. Many different forms of work are directly and indirectly involved in the creation and sharing of information and knowledge at universities beyond the academic activities of scholars. Think for example of the secretary who organises the administration behind teaching, the librarian who arranges books and journals, the IT technologist who maintains the websites and servers at universities, the manual worker who services the equipment in classrooms, the cleaner and janitor who keep the university building running, etc. Academic activities would hardly be possible without all these different forms of labour at universities. This just indicates that work tends to be a social process where many individuals are involved and what Marx termed 'Gesamtarbeiter' (collective worker). Marx argues that work tends to be a combination of workers, a combined labour force, resulting in a combined product. 'In order to work productively, it is no longer necessary for the individual himself to put his hand to the object; it is sufficient for him to be an organ of the collective labourer, and to perform any one of its subordinate functions' (Marx 1976, 643-644). If we take a look at the higher education landscape in Scotland, one can see how many other forms of work are involved beyond academic work at universities. 19,250 academics, 10,515 academic atypical staff and 23,650 non-academic staff worked at Scottish universities in 2014/2015 (Higher Education Statistics Agency 2016). That means 44.3 per cent are non-academic workers such as administrators, technologists, manual workers etc. at universities. If we talk about labour at universities, one should not oversee this form of work and workforce that comprises almost half of the workers in absolute numbers at least in the Scottish context. To be precise, one could make the distinction between academic work of research and teaching and academic work of administration and technological assistance at universities. However, these tasks are overlapping to a certain extent; for example, academic workers also have to conduct administrative tasks such as keeping registers of their student cohort. Similar to a broad definition of cultural labour (Fuchs and Sandoval 2014, 488), taking into account all different forms of work that are directly and indirectly involved in the creation and sharing of academic knowledge (1) avoids an idealistic understanding of academic work that ignores its materiality, (2) considers the connectedness of technology and content and (3) can inform political solidarities between different groups within universities.

\subsection{Conditions of Academic Labour}

The neoliberal restructuring of universities led to transformations such as reducing public expenditure, squeezing costs, allocating resources based on competition and quasi-market disciplines. These structural transformations have an effect on the working conditions, practices and relations of subjects within universities. This is also reflected in a growing academic literature reporting about the changes in the working conditions, especially at places where the neoliberal restructuring can be considered as relatively advanced and has been going on for some decades such as the UK, Netherlands, US and Australia (Lorenz 2012, 600).

Sandoval $(2013,323-325)$ provides a systematic model of working conditions based on Marx' circuit of capital accumulation that can be applied to different sectors. The model identifies dimensions that shape working conditions in the capital accumu- 
lation process. In addition, the model includes the impact of the state's labour legislation on working conditions.

- Means of production: objects (resources) and instruments (technology) of labour

- Labour power: workforce characteristics, mental and physical health, work experiences

- Relations of production: labour contract, wages and benefits, labour struggles

- Process of production: labour space, labour time, work activity, control mechanism

- Commodity: labour product

- The state: labour legislation

The model helps to systematically analyse the labour process and can also be applied to academic labour. The overall aim of this section is to introduce an overview of working conditions at universities.

- Means of production: objects (resources) and instruments (technology) of labour

Resources: Resources in the academic labour process consist of knowledge, skills and practices of the human brain and hands.

Technology: Technologies that are used in the academic labour process include for example libraries, computers, laboratories and equipment.

- Labour power: workforce characteristics, mental and physical health, work experiences; we can also add unemployment

Workforce characteristics: Important characteristics of the workforce are class, gender, ethnicity, age and disability. Altogether, there are 273,895 academics (partand full-time academic staff and academic atypical staff) in UK higher education. 37.0 per cent of full-time academic staff have contract salaries between $£ 43,325$ and $£ 58,172$. Higher proportions of male full-time academic staff ( 25.3 per cent) have contract salaries of $£ 58,172$ or over than female full-time academic staff (13.9 per cent). The proportion of academic females is 45.0 per cent. For full-time academic staff the proportion of females is 40.0 per cent and for part-time 55.1 per cent. 47.2 per cent of the academic atypical staff population are women. 13.9 per cent of academic staff and 17.2 per cent of academic atypical staff are ethnic minorities with a background such as Black, Asian, Chinese and mixed. 4.1 per cent of academic staff and 2.4 per cent of academic atypical staff declared a disability. The average age of full-time academic staff is 43 years and of part-time academic staff 46 years. The average age of academic atypical staff is 40 years. Among other characteristics, young women with a minority background are most likely to work precariously in UK higher education (Bryson and Barnes 2000, 209). In addition, the higher the hierarchy, the fewer women one can find in higher education. For example, 56.2 per cent of students in the UK are female, but only 23.1 per cent of the professors are women (all data for the academic year 2014/2015: Higher Education Statistics Agency 2016).

Mental and physical health: Different empirical studies have reported about mental and physical health issues at higher education institutions. In a survey of the University and College Union $(2014,2), 60$ per cent of the respondents showed evidence of some level of psychological distress. According to Watts and Robertson (2011), the burnout level amongst teaching staff at universities is comparable with 'at risk' groups such as healthcare professionals. The psychological distress of academ- 
ics exceeds many other professional groups and is caused by factors such as high level of conflict between work and private life (Kinman and Wray 2013,6). Academic and academic-related work tends to 'spill over into the home domain both physically (e.g. working at home during evenings and weekends), and psychologically (e.g. preoccupation with work problems, difficulties in sleeping, and irritability with family and friends)' (Ibid., 7).

Work experiences: The question of how academics experience their working conditions is an empirical one. Several authors have already conducted empirical work in this context. For example, Prichard and Willmott (1997, 313-314) ran 36 interviews with senior post holders such as chancellors, heads and deans at 4 pre- and post-1992 universities in the UK about their experiences, consequences and changes of work. Archer $(2008,269)$ conducted eight semi-structured interviews with earlycareer academics at different universities in England about their identities and experiences in higher education. Deem et al. $(2007,33)$ realised a large-scale project about managerialism, management practices and organisational forms at universities in the UK between 1998 and 2000. The authors carried out in phase one 12 focus group discussions with academics, managers and administrators, in phase two 137 qualitative interviews with manager-academics and 29 senior administrators in 16 pre- and post-1992 universities and in phase three interviews with employees from manual workers to staff at four universities. I conducted 10 semi-structured, face-toface, qualitative interviews with academics. Focus was given to people who are employed 'atypically' such as on a fixed-term contract, casual contract, hourly paid basis, zero-hour contract, etc. at higher education institutions in Scotland. The scripts were analysed in order to find answers to my questions about how academics perceive the existing working conditions that are shaped by political and economic contexts (Allmer 2018).

Unemployment: For Marx (1976, 790), the working class consists of an active army of workers and a reserve army of unemployed. The unemployed are not a social group outside, but rather part of class relations fulfilling certain functions in and therefore necessary for capitalist societies as they 'become a condition for the existence of the capitalist mode of production' (Ibid., 784). Firstly, the unemployed play an important role as reserve being available if needed. Secondly, the unemployed are also important ideologically in order to keep pressure on those within the production process (lbid., 785). The employed and unemployed condition, but simultaneously exclude each other in capitalism. The vast expansion of higher education in the last decades has also led to a massive increase in graduates and doctoral students and thereby automatically contributed to the expansion of the academic reserve army; or at least, to an expansion of a social group willing to accept precarious working conditions for a certain period in their lives, before reaching a more secure post. Universities are nowadays able to choose from a pool of mainly early-career academics if needed in times of high demand (Shumar 1995, 94). The unemployed and precariously employed academics compete with each other and try to perform well for the sake and prospect of employment and a more secure post. An ideological pressure and disciplinary mechanism on employed academics is in place as they could be easily downgraded or even replaced by some from the surplus labour pool. 'One of the consequences of the vast expansion of post-secondary education in North America and Europe has been the gradual establishment of a huge pool of surplus researchers, instructors and laboratory assistants, drawn from the ranks of graduate students, whose prospects for permanent academic employment are scandalously low' (Dyer-Witheford 2011, 281). 
- Relations of production: labour contract, wages and benefits, labour struggles

Labour contract: One important aspect of an academic employment contract is its permanent/open-ended or temporary character. Many different forms of temporalities exist, including fixed-term, hourly paid and zero hour contracts. A tendency of casualisation and temporality of employment characterises higher education in the UK. According to the Higher Education Statistics Agency (2016), 128,300 permanent/openended and 70,035 fixed-term academic staff worked at universities in the UK in the academic year 2014/2015. On top of that, there were 75,560 academic atypical staff in the same year. Summing up those on a fixed-term contract and the academic atypical staff means that the majority (53.2 per cent) work on a temporary basis in UK higher education. Casualisation allows the university to test the performance of the academic, strengthens Darwinian selection, reduces labour costs and gives the opportunity to respond quickly to changes on the education market in order to deal with low and high peaks of demand (Bryson and Barnes 2000,193). The amount of staff needed also depends on how successful a university is in terms of marketing and attracting students for the upcoming academic year. Universities compete with each other on a market of potential new students. Casualisation of academic staff can thus be considered as an outcome of applying quasi-market, neoliberal rules at higher education institutions. 'The university could never be sure about enrolments size or profitability; it had to remain forever poised to take action, to stimulate enrolment, to cut costs, to keep growing. The permanent flexibility this required meant that the staff had to be proletarianized and stratified into temporary part-time workers, permanent teachers and permanent researchers' (Shumar 1995, 94). Pratt (1997) highlights that employing part-time and fixed-term staff at universities has become a management strategy. Those working at a pre-92 university, are on research only contracts, work part-time, have up to five years work experience, are female and under the age of 40 as well as non-white and non-UK are most likely to be on temporary contracts (Bryson and Barnes 2000, 209). Temporary contracts tend to have an impact on the employee's economic security and control, exclusion from the department, relationships with other colleagues, and a lack of opportunity for career development and promotion (Ibid., 217). Gulli $(2009,5)$ highlights that the expansion of temporary staff is typical for the neoliberal discourse as it brings flexibility to the university at the cost of individual insecurity that can lead to anxiety, disruption, stigmatisation and loss of dignity. A contradiction between inclusion and exclusion characterises the employment of temporary staff as it is much needed and included in economic terms, but tends to be invisible and exposed and therefore excluded in social and political terms. Tirelli (1999) therefore stresses that casual contracts trigger labour segmentations within the academic workforce leading to increased hierarchies and potentials of conflict. Neoliberal universities tend to decrease the number of established and respected permanent staff and increase the number of relatively powerless temporary staff. From a trade union point of view, casualisation brings also political changes that advantages the management and weakens the academic workforce. 'Faced with a restive mass of immaterial labour, university administrator's best strategy backed by centuries of academic hierarchy - is to ensure that regular and contingent faculty remains divided' (Dyer-Witheford 2005, 78).

Van Dyk and Reitz (2016) argue that universities are becoming what Boltanski and Chiapello call the 'projective city'. The projective city signifies the idea of the new spirit of capitalism that is based on projects sparking temporary compression of net- 
works, competition of project teams on the market and new work ethics and forms of employees' motivation. 'This refers to a firm whose structure comprises a multiplicity of projects associating a variety of people, some of whom participate in several projects. Since the very nature of this type of project is to have a beginning and an end, projects succeed and take over from one another, reconstructing work groups or teams in accordance with priorities or needs' (Boltanski and Chiapello 2007, 105). Statistics confirm this trend for the Scottish higher education landscape: 72.9 per cent of the total annual research income for Scottish universities is gained from research grants and contracts such as research councils, societies, charities, corporations, EU sources (for the time being) etc. In comparison, only 27.1 per cent go directly to the universities in form of recurrent research income as result of the $\mathrm{Re}-$ search Excellence Framework (all data for the academic year 2014/2015: Higher Education Statistics Agency 2016). Most of these funds are project-based and competitive. Academics employed in such projects mainly work on a temporary basis.

Wages and benefits: The question of wages and benefits is a relational one. Considered historically, academics have been a relatively privileged group of employees (Callinicos 2006, 24). If one compares the salary and social advantages like annual leave entitlement or pension benefits to other groups such as social and health workers, one has to admit that academics still enjoy benefits that are not or not any more available in other sectors. But there is a contingent struggle in terms of academic salaries and benefits. Callinicos $(2006,25)$ stresses that academics have seen their pay stagnated in real terms and declined relatively in the last century. The University and College Union (2016c) highlights a $14.5 \%$ loss in real terms of salaries in higher education measured against inflation since 2009. Pay scales are also highly stratified in the higher education sector. For example, the vice chancellor (or equivalent) at the University of Strathclyde, Glasgow, receives an annual salary of $£ 343,000$. In contrast, a FTE (full-time equivalent) annual salary of an hourly paid academic at the same university is $£ 17,995$ (with an assumed hourly rate of $£ 23$ ) (all data for the academic year 2014/2015: University and College Union 2016b). This means the vice chancellor earns 19 times more than an hourly paid academic at the University of Strathclyde. Similar calculations can be worked out for other universities.

Labour struggles: As already mentioned, academics have traditionally been a relatively privileged group of employees and universities were historically considered as communities with shared values and interests in the UK. This was also reflected in absorbed labour struggles and a weak union of higher education. Consequently, the Association of University Teachers (AUT) did not see itself as a trade union, but rather as a professional association (Callinicos 2006, 24). In contrast, academic staff in the post-1992 universities and college teachers enjoyed less privileged conditions in the past. Their union, the National Association of Teachers in Further and Higher Education (NATFHE), has 'developed a much more militant tradition of trade unionism, and has tended to be led from the left' (Ibid., 25). Supported by the fact that this union also represented college teachers, who were already confronted with a rather brutal neoliberal reorganisation. The two organisations merged in 2006 to the University and College Union (UCU). Callinicos $(2006,36)$ notices that the material conditions of neoliberal restructuring in higher education in the last decades have resulted in a more active trade unionism among academics in general. The University and College Union has today more than 100,00 members and its policies include the fight against the privatisation of education, casualisation, workload and stress as well as organising the collective pay bargaining for academic staff. According to Harvie 
$(2006,21)$, the opposition of academic unionism is nowadays more or less opposition to neoliberalism.

- Process of production: labour space, labour time, work activity, control mechanism

Labour space and time: In analogy to the idea of the factory without walls from Autonomist Marxism, Gill (2010) argues that the neoliberal university can be considered as academia without walls. Autonomist Marxism claims that capital tends to subsume the whole society into the production process and the logic of the factory is extended to society (Wright 2002, 37-38). Society functions as a moment of production, where the boarder between working and spare time becomes more and more blurred (Gorz $2010,22)$ both spatially and temporally. The social factory is therefore a 'factory without walls' (Dyer-Witheford 1999, 80). Likewise, neoliberal universities have intensified work in terms of time and extended in terms of space with the help of digital technologies. Academics tend to have fluid boundaries between their working space and other spaces of human life and their labour and free time (Ross 2000, 23). Always-on cultures have transformed the university to a fast academia. 'Ever speededup mobile technologies intermesh seamlessly with the psychic habitus and dispositions of the neoliberal academic subject: checking, monitoring, downloading whether from BL (British Library), beach or bed, trying desperately to keep up and "stay on top"' (Gill 2010, 237). This indicates how a technological change of the productive forces can have an effect on the working conditions within the production process.

This theoretical assumption can be underpinned with empirical data. The University and College Union has conducted several online surveys about workload and work-related stress in the UK (Court and Kinman 2009; Kinman and Wray 2013; University and College Union 2014; 2016a). In 2014 (n=6,439), 79 per cent of the participants agreed or strongly agreed that they find their job stressful. 53 per cent indicated that their general or average level of stress was high or very high. Almost half (48 per cent) responded that they experience often or always unacceptable levels of stress (University and College Union 2014, 1-2). According to the 2016 survey $(n=12,113)$, academic staff works an average of more than 50 hours FTE per week. Especially amongst early career academics exists a culture of long working hours (University and College Union 2016a, 18). Factors contributing to stress in higher education include among others the lack of time to undertake research, excessive workloads, problems in obtaining funding, lack of promotion opportunities and job insecurity (Court and Kinman 2009, 61). Academics tend to regularly work evenings and weekends in order to cope with the high demands of their job (Gill 2010, 235) and not taking their full entitlement of annual leave (Crang 2007, 510).

Work activity: A tendency of narrow specialisation, routine tasks, division and standardisation of work characterises academia. Teaching and research are becoming increasingly separated (Liesner 2006, 484). Especially casualised staff is confronted with a lack of autonomy in teaching, break down of teaching into isolable units, decreasing authority of the individual educator and predefined and predesigned modules and programmes that potentially lead to frustration and dissatisfaction. In analogy to the assembly line worker, Hanley $(2002,30)$ describes this process as 'Taylorization of academic labor'. Harvie argues that school and university teachers become alienated from their work activity, an activity that does not belong to them. 'The very separation of knowledge into more-or-less well-defined and discrete "disciplines" or "subject's" constraints the majority of teachers within "their" subject's boundaries' (Harvie 2006, 10-11). Similar, research is becoming gradually homoge- 
nised due to 'hot topics' and increasing difficulties in obtaining funding. Lorenz (2012, 613) states that intrinsic satisfaction has been replaced by externally driven rewards.

Control mechanism: Although procedures of surveillance, monitoring and audit cultures are no new control mechanisms within universities (for example: the Research Assessment Exercise has been in place since the 1980s), nor is the university by far the only place of surveillance (see: Allmer 2012), they have been taking hold significantly at higher education institutions in the UK for some years now (Burrows 2012, 357). Metrics operate at different stages such as the institutional, national and international level, but all of them confront the individual academic (Burrows 2012, 359). New information and communication technologies have helped to intensify and extend these procedures, which indicates the link to the means of production. An elaborate set of monitoring procedures and metrics exists at universities, including grant income, citation scores, workload models, transparent costing data, research 'excellence', student evaluation, employability scores, impact factors and commercial university league tables (De Angelis and Harvie 2009, 11-14). Burrows (2012, 359) identifies that British academics are now subject to more than 100 different scales and indices. Academics are measured individually against other colleagues as well as grouped and measured against other groups in order to assess and rank academic values. Gill (2014, 22-24) argues that surveillance culture and audit regimes lead to a new psyche and structures of feeling at universities that includes individual pressure, anxiety and threats. The proliferation of league tables triggered a culture of naming and shaming that results into self-surveillance. 'Being hard-working, selfmotivating and enterprising subjects is what constitutes academics as so perfectly emblematic of this neoliberal moment, but is also part of a psychic landscape in which not being successful [...] is misrecognised [...] in terms of individual (moral) failure' (Gill 2010, 240).

'New managerialism' is another control mechanism that has been implemented at higher education institutions in the last decades. New managerialism can be understood as the adoption of organisational forms, technologies, managerial control practices and ideologies from the private business to the public sector such as universities (Deem, Hillyard and Reed 2007, 24-28). As response to the post-Fordist conditions, UK universities are becoming increasingly corporately managed. Academic professions are thereby broken up into controllable processes (Lorenz 2012, 610). The private sector style of management includes the realisation of a hierarchical organisation structure, division and standardisation of work, narrow specialisation and routine tasks in order to increase accountability and measurement by management. Prichard and Willmott (1997) highlight that universities implemented many elements of 'soft managerialism' urging academics to meet performance targets and thereby encouraging self-discipline without the need of 'hard management'. As a result of the pressure to meet performance objectives, individual resources for actively participating in the decision-making process on the institutional and school level are becoming scarce. 'Yet, in effect, increased managerialism implies that the input of staff into decision-making is degraded from collegial participation to, at best, a consultative role in which staff willingly accept and support their heads of department who then managerialize the process through which resources are won and allocated' (Willmott 1995, 996). Tancred-Sheriff $(1985,384)$ compares the decision-making process at universities with a 'kiddie steering wheel in daddy's car' with heaps of relatively powerless committees and panels, despite formal decision-making powers. Prichard and Willmott (1997) conducted 36 interviews with senior post holders such as vicechancellor, dean, head of school and head of department at four UK universities 
about their understanding of managerialism. The authors report that their interviewees 'talked of the implementation of strategic initiatives, of managing staff, of taking responsibility and even of being a small-businessman' (Prichard and Willmott 1997, 313). Miller $(1991,111)$ argues that vice-chancellors tend to act like chief executives.

- Commodity: labour product

Labour product: The work of academics results into research outputs such as publications and technical innovations and teaching degrees hold by bachelor, master and $\mathrm{PhD}$ graduates. Many research outputs are published by for-profit academic publishing companies such as RELX (former Reed Elsevier), Springer, Taylor \& Francis and Wiley-Blackwell and appear in corporate databases such as the Thomson Reuters' Science and Social Science Citation Indexes. These industries are highly monopolised, commodify and thereby restrict access to academic knowledge, have the power to decide who is 'in' and 'out', and privatise knowledge being produced in publicly funded research institutions (Hall 2008). Harvie $(2006,12)$ mentions that the work of school and university teachers' results into graduates who are supposed to be bearers of a range of knowledge, skills and attributes. But those skills tend to correspond to valuable labour power skills, increasingly determined by the needs of capital. Teachers produce labour power for capital and are thus alienated from the product of their labour.

- The state: labour legislation

Labour legislation: McGettigan (2013) argues that the broader vision of higher education in the UK is that the state rolls back gradually through processes of privatisation and the remaining public areas are characterised by quasi-market regulations. Different processes, policy considerations and initiatives have been brought forward in this context (Ibid., 9):

1. 'Marketisation or external privatisation, whereby new operations with different corporate forms are allowed to enter the state system to increase competition. This might be seen as dissolving the distinction between separate public and private sectors.'

2. 'Commodification - the presentation of higher education as solely a private benefit to the individual consumer; even as a financial asset where the return on investment is seen in higher earnings upon graduation.'

3. 'Independence from regulation - private providers accessing the student loan book are not bound by numbers controls and do not have to comply with reporting or monitoring requirements nor widen participation initiatives.'

4. 'Internal privatisation - the changes to revenue streams within institutions so that for example, direct public funding is replaced by private tuition fee income.'

5. 'The outsourcing of jobs and activities to the private sector and management consultants, which has become widespread in England.'

6. 'Changes to the corporate form and governance structures of universities.'

7. 'The entry of private capital and investment into the sector through buyout and joint ventures with established institutions.'

Table 1 summarises the conditions of academic labour with the key elements of each of the dimensions in the capital accumulation process and the impact of the state. 


\begin{tabular}{|c|c|c|}
\hline $\begin{array}{l}\text { Capital Accumulation } \\
\text { Process and the State }\end{array}$ & Dimension & Elements \\
\hline \multirow[t]{2}{*}{ Means of production } & Resources & $\begin{array}{l}\text { Knowledge, skills and prac- } \\
\text { tices of the human brain and } \\
\text { hands }\end{array}$ \\
\hline & Technology & $\begin{array}{l}\text { Libraries, computers, la- } \\
\text { boratories and equipment }\end{array}$ \\
\hline \multirow[t]{4}{*}{ Labour power } & Workforce characteristics & $\begin{array}{l}\text { Class, gender, ethnicity, age } \\
\text { and disability }\end{array}$ \\
\hline & Mental and physical health & $\begin{array}{l}\text { Psychological distress and } \\
\text { burnout }\end{array}$ \\
\hline & Work experiences & $\begin{array}{l}\text { Prichard (1997), Archer } \\
\text { (2008), Deem (2007) and } \\
\text { Allmer (2018) }\end{array}$ \\
\hline & Unemployment & $\begin{array}{l}\text { Academic reserve army: } \\
\text { material reserve and ideo- } \\
\text { logical pressure }\end{array}$ \\
\hline \multirow[t]{3}{*}{ Relations of production } & Labour contract & $\begin{array}{l}\text { Casualisation and temporali- } \\
\text { ty }\end{array}$ \\
\hline & Wages and benefits & $\begin{array}{l}\text { Stagnation, decline and un- } \\
\text { equal distribution }\end{array}$ \\
\hline & Labour struggles & $\begin{array}{l}\text { Academic unionism and op- } \\
\text { position to neoliberalism }\end{array}$ \\
\hline \multirow[t]{3}{*}{ Process of production } & Labour space and time & $\begin{array}{l}\text { Academia without walls: } \\
\text { intensification and extension } \\
\text { of work, always-on culture } \\
\text { and fast academia }\end{array}$ \\
\hline & Work activity & $\begin{array}{l}\text { Taylorisation: narrow spe- } \\
\text { cialisation, routine tasks, } \\
\text { division, standardisation and } \\
\text { homogenisation of work }\end{array}$ \\
\hline & Control mechanism & $\begin{array}{l}\text { Surveillance, monitoring, } \\
\text { audit culture, metrics and } \\
\text { new managerialism }\end{array}$ \\
\hline Commodity & Labour product & $\begin{array}{l}\text { Research outputs: publica- } \\
\text { tions and technical innova- } \\
\text { tions; teaching degrees: } \\
\text { bachelor, master and PhD } \\
\text { graduates }\end{array}$ \\
\hline The state & Labour legislation & $\begin{array}{l}\text { Privatisation (internal and } \\
\text { external), commodification, } \\
\text { deregulation and outsourc- } \\
\text { ing }\end{array}$ \\
\hline
\end{tabular}

Table 1: Conditions of Academic Labour

All of these dimensions shape the working conditions at higher education institutions to a certain extent. Based on these insights, I now move on to the impact of new information and communication technologies on universities and academic labour. 


\section{Digital Academic Labour}

The academic work process is today strongly linked to the use of new information and communication technologies such as email communication, online education and digital registers for research, teaching and administration purposes. The use of technologies is not a new phenomenon at universities and one can argue that academics have always used some sort of technology as means for their work. For example, the chalk and blackboard served for many decades as an important tool in order to share knowledge in the classroom and was later accompanied by the overhead projector. The communication between university teachers and distance learning students used to take place via traditional letters sent by snail mail (Noble 2001, chapter 1) and is today fully replaced by digital communication. One can argue that educational technologies have been developed in analogy with the progress of the productive forces and reflects the historical development from agricultural to industrial to informational eras in capitalist societies. Although the application of technologies at universities is not new, the use of digital technologies is a relatively new phenomenon and has generated a rapid quantitative expansion that simultaneously raises questions of a qualitative shift. A gradual expansion of educational technologies (quantity) led to a new digital realm at universities (quality). The application of education technologies can thus be considered as a new and at the same time old development. A dialectics of continuity and discontinuity characterises the development of educational technologies.

Digital media are used for different research and teaching purposes. Here is an indicative list of different possibilities in using digital media for research:

- Online libraries

- Digital books and journals

- Online database

- Online research and digital methods

- Digital communication

- Virtual networks and conferences

Here is an indicative list of possibilities how new information and communication technologies are used for teaching and learning:

- Virtual learning environments such as Moodle and Blackboard

- Digital classroom

- Online lecture

- Wikis, Blogs and online discussion boards and forums

- Online video chats and voice calls

- Online tutorial, supervision and marking

- Massive Open Online Courses (MOOCs)

Digital academic labour is a specific form of academic labour that is mediated through digital media. Digital and non-digital media and resources often co-exist in the work experience of academics. One might think of someone, who uses Blackboard for teaching in order to upload documents for students and supervises students via email, but teaches in a physical classroom. Another example might be that researchers browse the library catalogue online, but still prefer to read the hard copy of a book. Digital technologies and resources have neither displaced non-digital ones 
fully, nor are non-digital technologies and resources completely independent of digital ones. It is as hard to imagine an academic who is able to manage his work without the use of digital media, as it is an academic without the use of non-digital media. Different people have different degrees in blending digital and non-digital media at their work.

While the pedagogical impact of digital media is not the focus of this paper, I would like to draw your attention to the economic aspect, especially in the context of teaching. According to McGettigan $(2013,115)$, the total annual income of UK universities is around $£ 30$ billion and more than 50 per cent come through teaching via tuition fees and public grants. Overseas tuition fees, i.e. fees from students from outside the EU such as China, play a crucial role in income for universities in the UK (McGettigan 2013, 117). Higher education institutions today compete on a global market for international students. Recruiting oversea students is particularly appealing in the UK, because institutions are not bound by the same restrictions as they are with Home and EU students (for the time being) - there is no cap in terms of fees and in terms of numbers. Generally speaking, there are at least three different possibilities to reach international students.

1. Foreign students come to the UK for studying at one of the universities

2. British universities install a branch campus abroad

3. Both remain in their home country and teaching is facilitated via digital media

The first option seems to be the most obvious one. If we take a look at Scotland, there are almost 30,000 non-EU students. Considered the full-time students separately (overseas students are not eligible to study part-time), 15.1 per cent of the student population in Scotland comes from non-EU countries. At the University of Edinburgh, there are more full-time postgraduate students coming from outside the EU $(3,100)$ than from the UK $(2,435)$ (all data for the academic year 2014/2015: Higher Education Statistics Agency 2016). There are political restrictions in recruiting nonEU students. Partly because the government has declared a target to reduce migration, which should also apply to students (McGettigan 2013,121) and brings some uncertainty in terms of economic planning for universities. Partly because the recruitment of overseas students and the accompanied sponsorship of visas brings up immigration rules and an onerous and cost-intensive administrative system for higher education institutions (Ibid.). This includes the proof of language skills and record keeping of attendance and study progress. 'Alternatively, if the students have difficulties coming into the country, then let's take the universities to them' (Ibid.).

The second option is to establish satellite campuses abroad for local students being appealed to receive a degree from a (prestigious) British university. While the official claim is to strengthen international research relationships, it can be considered as a further strategy to access the population of countries such as India, China and Indonesia (Ross 2009, 202). For example, the University of Nottingham has opened up campuses in Malaysia in 2000 and in Ningbo (China) in 2004, now with some thousands students. While there are today more than 200 oversea branch campuses mainly (co-)operated by US, UK and Australian universities, the success is rather limited and the business strategy can be considered as highly risky (McGettigan 2013, 122-123).

The third option is to offer courses and programmes being delivered by means of digital media (online distance learning). From a technical point of view, online teaching requires teachers and students with some hardware (computer and headset), 
software (as listed above) and an Internet access, the university mediates this relationship. Online distance learning is technically independent of space and time for both teachers and students as they can theoretically work from anywhere. Those programmes have been primarily brought forward by major higher education institutions such as the Open University and the University of Edinburgh in the UK and Stanford University, Harvard University and the Massachusetts Institute of Technology in the US. Because neither the student has to come to the foreign country, avoids being confronted with immigration regulations and saves money for travelling and relocation, nor has the university to invest in new campuses abroad, digital teaching can be considered as a very promising business strategy in recruiting more overseas students, although it also attracts UK and EU students.

The three different possibilities are not a linear historical development, where one attempt replaced the other, but rather a complex and contradictory field of changing strategies and economic ups and downs in the higher education market. These practices co-exist simultaneously, but digital education seems to be the most promising at the moment. The Higher Education Funding Council for England (HEFCE) $(2009,7)$ is quite clear on this matter: 'Effective use of technology [...] can also help institutions in $[\ldots]$ attracting overseas students [...] Distance learning [...] will [...] assist with the recruitment and retention of (international) learners'.

For Marx, the mode of production is based on productive forces (means of production and labour power) and relations of production (property relations). The productive forces are a system of living labour forces and facts and factors of the process of production that cause and influence labour (Leisewitz 1990, 939). The relations of production constitute social relations between human beings and specify who produces and who owns property (Krysmanski 1990). If we take a look at the mode of production at universities, one can see that the productive forces and relations are changing in the realm of digital education.

Productive forces: Although digital education causes new costs (for example for licence fees of digital software), universities are able to reduce the means of production such as buildings, equipment and facilities as they are outsourced to individuals and the private sphere. While students visit lecture halls, seminar rooms, laboratories, libraries etc. operated by the university for brick and mortar campus teaching, students visit a virtual space, but are physically at a private or other space of human life with an electronic device in the age of digital education (van Mourik Broekman et al. 2015, 22-23). In addition, the university has to invest in technologists who establish and maintain digital learning environments, but digital education potentially reduces labour costs in the long term due to reproducibility. One can imagine an online module conceptualised to watch recorded lectures by research-intensive professors and receive tutorials and supervision by cheap labour power such as teaching fellows and hourly-paid lecturers (Noble 1998). Different universities have different digital practices, but online distance learning can reduce labour power as lectures can be easily recorded and replayed, accompanied with some individuality. 'The marriage of corporate culture, higher education, and the new high-speed technologies also offers universities big opportunities to cut back on maintenance expenses, eliminate entire buildings such as libraries and classrooms, and trim labor costs' (Giroux 2002, 447). Due to the reduction of the productive forces, digital education can both provide a cost-efficient alternative and bring flexibility for universities in order to be able to respond quickly to changes in the higher education market in terms of demand (Massy and Zemsky 1995). An online module can be theoretically provided very quickly due 
to reduced material necessities and thus makes it likely to react appropriately to economic ups and downs on the student market.

Relations of production: Digital education poses new questions of intellectual property rights. Because ownership tends to follow authorship in copyright law, teaching staff traditionally owned their course material (Noble 2001, 38). This has been a long-established tradition and right at universities. If an academic left university, s/he had the right to take teaching material with him/her and was able use it for other purposes, because it belonged to the creator of educational content. As argued above, digital education can only reduce labour power and costs, if content can be recorded and reused (reproducibility). One could imagine a situation where a university aims to use recorded lectures and stored communication for an online module being originally developed by teaching staff, not working for this institution anymore. In case the university is not licensed to use this content, it could end up in either legal or economic problems. Higher education institutions thus have a strong interest in getting the intellectual property rights and licences of the developed teaching material. Universities must control the copyright. Different countries do have different practices, but it seems as the US higher education market is the most advanced in this context at the moment (Noble 2001, chapter 3). 'Ivy League schools have, in fact, developed some of the most aggressive and sophisticated examples of commercial online education' (Werry 2002, 35). Noble $(2001,38)$ argues that research has already been commodified, but with digital education, course material follows a similar pattern. For research tasks, employees are contractually required to assign the patent rights to the university as routine condition of employment. Similarly, employees might be forced to assign the copyright and licence of course material stored on PCs, websites and courseware as routine condition of employment in the realm of online teaching. This transforms the nature of teaching and the relationship between higher education institutions and their employees. 'Like the commercialization of research, the commercialization of instruction entails a fundamental change in the relationship between the universities and their faculty employees. Here faculty who develop and teach face-to-face courses as their primary responsibility as educators are transformed into mere producers of marketable instructional commodities that they may or may not themselves "deliver"' (Ibid.).

Digital education and technologies have an impact on the working conditions of academics. If we reconsider the different stages of the capital accumulation process as outlined in the previous section, one can see the risk that conditions of labour are being intensified and extended in the realm of digital media; to name but a few, the blurring of working space and other spaces of human life, the blurring of labour and free time, fast academia, always on cultures, deskilling, casualisation, electronic monitoring, digital surveillance, social media use for self-promotion, and new forms of intellectual property rights (Noble 1998; Gregg 2013; Lupton 2014, 79-83; Poritz and Rees 2017, 68-82).

One could argue that digital education and technologies widen access for people from poorer backgrounds, women, ethnic minorities and disabled and thereby provide inclusion, equality of opportunities and social justice. For example, HEFCE (2009, 7-8) promotes that technologies enhance learning and teaching that open access and opportunity and bring equality of access, inclusion, flexible lifelong learning and international mobility. The argument that new technologies in education automatically bring enhancement can be considered as a techno-optimistic and technodeterministic view that tends to ignore the social sphere and sees technology as being independent of its social context (Bayne 2015,5). For example, it is difficult to 
imagine how digital education should widen access for people from poorer backgrounds, if such programmes tend to be rather expensive with similar fees as their offline companions. Digital education can bring advantages for disabled people, being able to study at their own pace, but might involve the risk of new forms of social exclusion. Noble (1998) draws a possible future where digital education will become the second-class education, while traditional on-campus teaching will become the exclusive privilege of the rich and the powerful - the poor get a computer, the rich get a computer and a teacher. 'In the case of distance education, however, the digital divide is turned on its head, with the have-nots being compelled to take their courses online while the haves get to do it in person' (Noble 2001, 90). In similar vein, Giroux (2002, 448-449) argues that 'a class-specific divide begins to appear in which poor and marginalized students will get low-cost, low-skilled knowledge and second rate degrees from online sources, while those students being educated for leadership positions in the elite schools will be versed in personal and socially interactive pedagogies in which high-powered knowledge, critical thinking, and problem-solving will be a priority, coupled with a high-status degree'.

Universities are keen on promoting that their offered online programmes are internationally recognised degrees and of equal value to on-campus programmes (for example: University of Edinburgh 2016), but the risk still exists that employers tend to favour on-campus degrees when it comes to the recruitment process (Linardopoulos 2012; Fogle and Elliott 2013). Given the fact that digital technologies in higher education are still in a relatively early stage, the development of the cohort in terms of social background is difficult to predict and remains an empirical question. But it gets clear that online education fits neatly within the neoliberal agenda. An increasing need of a highly qualified, skilled and trained workforce characterises contemporary capitalism that leads to higher pressure of further education and lifelong learning processes. People tend to live under stressed and tightened circumstances, fulfilling several tasks and commitments such as full-time jobs and family and social relations at the same time (Rosa 2013). Digital education helps to compensate this dichotomy by offering a higher education qualification in a very flexible route as it tends to be independent of time and space. Digital education can thus be considered as a response to neoliberal conditions.

\section{Conclusion and Alternatives}

Based on a critical social theory approach and moving from the abstract to the contract level, this article has engaged with the history and context of universities, dealt with the forms and concepts of academic labour and provided a systematic analysis of working conditions at higher education institutions. It has furthermore discussed the impact of new information and communication technologies on academic labour.

According to Winn $(2015,4,10)$, the academic labour studies literature tends to deal with historical, theoretical and critical questions inadequately. The aim of this article has thus been to contextualise universities historically within capitalism and to analyse academic labour and the deployment of digital media theoretically and critically. The key arguments can be summarised as follows:

- Historical context: The post-war expansion of the university can be considered as medium and outcome of informational capitalism and as a dialectical development of social achievement and advanced commodification.

- Academic labour: Academic workers and students are part of the knowledge workforce producing the commons, indirectly creating surplus value and exploited by 
capital. Academic labour is a specific historical form of academic work. Academic work is part of informational work that is part of cultural work. A broad definition of university labour, taking into account all different forms of work that are directly and indirectly involved in the creation and sharing of academic knowledge, can inform political solidarities between different groups within universities.

- A theoretical model of working conditions helps to systematically analyse the academic labour process and to provide an overview of working conditions at universities. The following dimensions shape the working conditions at universities: resources, technology, workforce characteristics, mental and physical health, work experiences, labour contract, wages and benefits, labour struggles, labour space and time, work activity, control mechanism, labour product, and labour legislation.

- Digital media: The academic work process is today strongly linked to the usage of new information and communication technologies. A dialectics of continuity and discontinuity characterises the development of educational technologies. Digital academic labour is a specific form of academic labour that is mediated through digital media. The deployment of digital media has an impact on the working conditions of academics, including the blurring of labour and free time, fast academia, and electronic monitoring.

I recently conducted interviews with precariously employed academics in Scotland (see Allmer 2018). One of the results indicates that people value and see the importance of solidarity, participation and democracy. A young researcher tells me that speaking to other precariously employed academics helps to understand patterns of anxieties. She feels it might be better to organise those who are in similar situations and take some agency, instead of feeling alone and powerless:

'There is an awareness that there is loads of us in the same position which is the only comfort about it. I think it does get to the point where you just have to take some agency [...] Maybe we should try and use that, the people who are in a similar position to me, we should actually [...] rather than just feeling like we are alone, we should do something about that, instead of just waiting about.' (Participant 8)

This advances the question about political potentials, challenges and strategies. Wright $(2010,304)$ distinguishes between three visions of social transformation that correspond broadly to the anarchist, social democratic and revolutionary tradition. The anarchist tradition revolves around social movements, aiming to build alternatives outside of the state; typically the labour movement plays a particular central role in the social democratic tradition, struggling on the terrain of the state; the revolutionary tradition is connected to the Marxist tradition, attacking the state and confronting the bourgeoisie. These strategies should be brought together not only to 'envision real utopias, but contribute to making utopias real' (Wright 2010, 373). In order to avoid pitfalls of co-option and marginalisation on a political level, Wright's vision of the anarchist, social democratic and revolutionary tradition can be connected to the three sections of this article: digital media, academic labour and historical context. Although the deployment of digital media at universities entails the risk that conditions of labour are being intensified and extended, new information and communication technologies can also help to create critical, counter-hegemonic education alternatives outside of the university (anarchist tradition). A broad definition of university labour and a systematic analysis of working conditions point to the need of struggling on the terrain of the university (social democratic tradition). A historical contextualisation of the university within capitalism indicates that the struggle for better universities 
should aim beyond criticising neoliberal developments and restoring Fordist configurations (revolutionary tradition).

- Digital media - anarchist tradition: Managing the progressive potentials of digital media, we need to establish and engage in critical education alternatives outside the university campus. This could involve open education movements (Winn 2012), open access and copyleft resources (Hall 2008), creative and digital commons, and the Wikiversity (van Mourik Broekman et al. 2015).

- Academic labour - social democratic tradition: We need to reclaim the university as site of struggle for all university workers, including academics, students, clerical, technical and manual workers. This requires solidarity, collectivity, participation, democratisation, resistance, opposition, unionisation (Bailey and Freedman 2011) and can inform political solidarities between different groups within universities (and to find for example commonalities between outsourced cleaners fighting for sick pay, leave entitlement and pension scheme and hourly-paid academic staff at University of London's School of Oriental and African Studies ${ }^{1}$ ).

- Historical context - revolutionary tradition: We need to connect the struggle at universities with the global struggle against capitalism. As stated in the introduction, modern universities have always been part of and embedded into capitalism in political, economic and cultural terms. 'The struggle for better universities can't be separated from the movement against global capitalism itself' (Callinicos 2006, 7).

These various directions and strategies should be brought together in order to find commonalities of different struggles and contribute to making utopias real.

\section{References}

Allmer, Thomas. 2018. Precarious, Always-on and Flexible: A Case Study of Academic Working Conditions. European Journal of Communication: forthcoming.

Allmer, Thomas. 2012. Towards a Critical Theory of Surveillance in Informational Capitalism. Frankfurt am Main: Peter Lang.

Archer, Louise. 2008. The New Neoliberal Subjects? Young/er Academics' Constructions of Professional Identity. Journal of Education Policy 23 (3): 265-285.

Bailey, Michael and Des Freedman. 2011. The Assault on Universities: A Manifesto for Resistance. London: Pluto Press.

Bayne, Siân. 2015. What's the Matter with 'Technology-Enhanced Learning'? Learning, Media and Technology 40 (1): 5-20.

Boltanski, Luc and Ėve Chiapello. 2007. The New Spirit of Capitalism. 2nd ed. London: Verso Books.

Bourdieu, Pierre. 1977. Outline of a Theory of Practice. Cambridge: Cambridge University Press.

Bryson, Colin and Nikki Barnes. 2000. The Casualisation of Employment in Higher Education in the United Kingdom. Academic Work and Life 1: 187-241.

Bulut, Ergin. 2011. Creative Economy: Seeds of Social Collaboration or Capital's Hunt for General Intellect and Imagination? In Cognitive Capitalism, Education and Digital Labor, edited by Michael Peters and Ergin Bulut, 151-168. New York: Peter Lang.

Burrows, Roger. 2012. Living with the H-Index? Metric Assemblages in the Contemporary Academy. Sociological Review 60 (2): 355-372.

Callinicos, Alex. 2006. Universities in a Neoliberal World. London: Bookmarks Publications.

1 As shown in the documentary 'Limpiadores' (2015) by Fernando González Mitjáns, see: https://www.youtube.com/watch?v=Upb3OK-jclM 
Court, Stephen and Gail Kinman. 2009. Tackling Stress in Higher Education. London: University and College Union. Accessed 11 January 2018. https://www.ucu.org.uk/media/3021/Tackling-stress-in-higher-education-UCU-surveyfindings-Dec-08/pdf/ucu hestress dec08.pdf

Crang, Mike. 2007. Flexible and Fixed Times Working in the Academy. Environment and Planning A 39 (3): 509-514.

De Angelis, Massimo and David Harvie. 2009. 'Cognitive Capitalism' and the Rat Race: How Capital Measures Immaterial Labour in British Universities. Historical Materialism 17: 330.

Deem, Rosemary, Sam Hillyard and Mike Reed. 2007. Knowledge, Higher Education, and the New Managerialism: The Changing Management of UK Universities. Oxford: Oxford University Press.

Dyer-Witheford, Nick. 2011. In the Ruined Laboratory of Futuristic Accumulation: Immaterial Labour and the University Crisis. In Cognitive Capitalism, Education and Digital Labor, edited by Michael Peters and Ergin Bulut, 275-286. New York: Peter Lang.

Dyer-Witheford, Nick. 2007. Commonism. Turbulence 1: 81-87. Accessed 11 January 2018. http://turbulence.org.uk/wp-content/uploads/2008/07/turbulence jirnl.pdf

Dyer-Witheford, Nick. 2005. Cognitive Capitalism and the Contested Campus. In Engineering Culture: On the Author as (Digital) Producer, edited by Geoff Cox and Joasia Krysa, 7193. New York: Autonomedia.

Dyer-Witheford, Nick. 1999. Cyber-Marx: Cycles and Circuits of Struggle in High-Technology Capitalism. Urbana: University of Illinois Press.

Fogle, Calvin and Devonda Elliott. 2013. The Market Value of Online Degrees as a Credible Credential. Global Education Journal (3): 1-25.

Fuchs, Christian. 2008. Internet and Society: Social Theory in the Information Age. New York: Routledge.

Fuchs, Christian and Marisol Sandoval. 2014. Digital Workers of the World Unite! A Framework for Critically Theorising and Analysing Digital Labour. tripleC: Communication, Capitalism \& Critique 12 (2): 486-563. Accessed 11 January 2018. http://www.triplec.at/index.php/tripleC/article/view/549

Fuchs, Christian and Sebastian Sevignani. 2013. What Is Digital Labour? What Is Digital Work? What's Their Difference? And Why Do These Questions Matter for Understanding Social Media? tripleC: Communication, Capitalism \& Critique 11 (2): 237-293. Accessed 11 January 2018. http://triple-c.at/index.php/tripleC/article/view/461

Giddens, Anthony. 1981. A Contemporary Critique of Historical Materialism: Volume 1: Power, Property and the State. Berkeley: University of California Press.

Gill, Rosalind. 2014. Academics, Cultural Workers and Critical Labour Studies. Journal of Cultural Economy 7 (1): 12-30.

Gill, Rosalind. 2010. Breaking the Silence: The Hidden Injuries of the Neoliberal University. In Secrecy and Silence in the Research Process: Feminist Reflections, edited by Róisín Ryan-Flood and Rosalind Gill, 228-244. London: Routledge.

Giroux, Henry. 2002. Neoliberalism, Corporate Culture, and the Promise of Higher Education: The University as a Democratic Public Sphere. Harvard Educational Review 72 (4): 425-463.

Gorz, André. 2010. The Immaterial: Knowledge, Value and Capital. London: Seagull Books.

Gregg, Melissa. 2013. Presence Bleed: Performing Professionalism Online. In Theorizing Cultural Work: Labour, Continuity and Change in the Creative Industries, edited by Mark Banks, Rosalind Gill and Stephanie Taylor, 122-134. London: Routledge.

Gulli, Bruno. 2009. Knowledge Production and the Superexploitation of Contingent Academic Labor. Workplace: A Journal for Academic Labor 16: 1-30. Accessed 11 January 2018. http://ices.library.ubc.ca/index.php/workplace/article/view/182232

Hall, Gary. 2008. Digitize This Book! The Politics of New Media, or Why We Need Open Access Now. Minneapolis: University of Minnesota Press. 
Hanley, Larry. 2002. Educational Technology and Academic Labour. Workplace: A Journal for Academic Labor 9: 28-33. Accessed 11 January 2018. http://ices.library.ubc.ca/index.php/workplace/article/view/184044

Hardt, Michael and Antonio Negri. 2009. Commonwealth. Cambridge: Harvard University Press.

Hardt, Michael and Antonio Negri. 2004. Multitude: War and Democracy in the Age of Empire. New York: Penguin Books.

Harris, Kevin. 1982. Teachers and Classes: A Marxist Analysis. London: Routledge.

Harvie, David. 2006. Value Production and Struggle in the Classroom: Teachers within, against and Beyond Capital. Capital \& Class 30 (1): 1-32.

Higher Education Funding Council for England. 2009. Enhancing Learning and Teaching through the Use of Technology. Bristol: Higher Education Funding Council for England. Accessed 11 January 2018.

http://webarchive.nationalarchives.gov.uk/20120716090505/http://www.hefce.ac.uk/pubs/y ear/2009/200912/

Higher Education Statistics Agency. 2016. Data and Analysis. Accessed April 6, 2017. Accessed 11 January 2018. https://www.hesa.ac.uk/data-and-analysis

Horkheimer, Max and Theodor Adorno. 1969. Dialektik der Aufklärung: Philosophische Fragmente. Frankfurt am Main: Fischer Verlag.

Jessop, Bob. 2002. The Future of the Capitalist State. Cambridge: Polity Press.

Kinman, Gail and Siobhan Wray. 2013. Higher Stress: A Survey of Stress and Well-Being among Staff in Higher Education. London: University and College Union. Accessed 11 January 2018. https://www.ucu.org.uk/media/5911/Higher-stress-a-survey-of-stress-andwell-being-among-staff-in-higher-education-Jul-13/pdf/HE stress report July 2013.pdf

Krysmanski, Hans-Jürgen. 1990. Produktionsverhältnisse. In Europäische Enzyklopädie zu Philosophie und Wissenschaften. Band 3, edited by Hans Jörg Sandkühler, 894-906. Hamburg: Felix Meiner.

Leisewitz, André. 1990. Produktivkräfte. In Europäische Enzyklopädie zu Philosophie und Wissenschaften: Band 3, edited by Hans Jörg Sandkühler, 914-945. Hamburg: Felix Meiner.

Liesner, Andrea. 2006. Education or Service? Remarks on Teaching and Learning in the Entrepreneurial University. Educational Philosophy and Theory 38 (4): 483-495.

Linardopoulos, Nikolaos. 2012. Employers' Perspectives of Online Education. Campus-Wide Information Systems 29 (3): 189-194.

Lorenz, Chris. 2012. If You're So Smart, Why Are You under Surveillance? Universities, Neoliberalism, and New Public Management. Critical Inquiry 38 (3): 599-629.

Lupton, Deborah. 2014. Digital Sociology. London: Routledge.

Mandel, Ernest. 1992. Introduction. In Capital: A Critique of Political Economy: Volume Two, edited by Karl Marx, 11-79. London: Penguin Books.

Marx, Karl. 1997. Grundrisse: Foundations of the Critique of Political Economy. Accessed April 26, 2013. http://www.marxists.org/archive/marx/works/1857/grundrisse/index.htm

Marx, Karl. 1976. Capital: A Critique of Political Economy: Volume One. London: Penguin Books.

Massy, William and Robert Zemsky. 1995. Using Information Technology to Enhance Academic Productivity. Accessed February 20, 2016. https://net.educause.edu/ir/library/html/nli0004.html

McGettigan, Andrew. 2013. The Great University Gamble: Money, Markets and the Future of Higher Education. London: Pluto Press.

Miller, Henry. 1991. Academics and Their Labour Process. In White-Collar Work: The NonManual Labour Process, edited by Chris Smith, David Knights and Hugh Willmott, 109137. Basingstoke: Macmillan Publishers.

Noble, David. 2001. Digital Diploma Mills: The Automation of Higher Education. New York: Monthly Review Press. 
Noble, David. 1998. Digital Diploma Mills: The Automation of Higher Education. First Monday 3 (1). Accessed 11 January 2018. http://journals.uic.edu/ojs/index.php/fm/article/view/569/490

Poritz, Jonathan and Jonathan Rees. 2017. Education Is Not an App: The Future of University Teaching in the Internet Age. London: Routledge.

Pratt, Linda Ray. 1997. Disposable Faculty: Part-Time Exploitation as Management Strategy. In Will Teach for Food: Academic Labor in Crisis, edited by Cary Nelson, 264-277. Minneapolis: University of Minnesota Press.

Prichard, Craig and Hugh Willmott. 1997. Just How Managed Is the Mcuniversity? Organization Studies 18 (2): 287-316.

Rosa, Hartmut. 2013. Social Acceleration: A New Theory of Modernity. New York: Columbia University Press.

Ross, Andrew. 2009. Nice Work If You Can Get It: Life and Labor in Precarious Times. New York: New York University Press.

Ross, Andrew. 2000. The Mental Labor Problem. Social Text 18 (2): 1-31.

Sandoval, Marisol. 2014. From Corporate to Social Media: Critical Perspectives on Corporate Social Responsibility in Media and Communication Industries. London: Routledge.

Sandoval, Marisol. 2013. Foxconned Labour as the Dark Side of the Information Age: Working Conditions at Apple's Contract Manufacturers in China. tripleC: Communication, Capitalism \& Critique 11 (2): 318-347. Accessed 11 January 2018. http://triplec.at/index.php/tripleC/article/view/481

Shumar, Wesley. 1995. Higher Education and the State: The Irony of Fordism in American Universities. In Academic Work: The Changing Labour Process in Higher Education, edited by John Smyth, 84-98. Buckingham: Society for Research in Higher Education \& Open University Press.

Tancred-Sheriff, Peta. 1985. Craft, Hierarchy and Bureaucracy: Modes of Control of the Academic Labour Process. Canadian Journal of Sociology 10 (4): 369-390.

Terranova, Tiziana and Marc Bousquet. 2004. Recomposing the University. Mute, July 13. Accessed 11 January 2018. http://www.metamute.org/editorial/articles/recomposinguniversity

Tirelli, Vincent. 1999. Adjuncts and More Adjuncts: Labor Segmentation and the Transformation of Higher Education. In Chalk Lines: The Politics of Work in the Managed University, edited by Randy Martin, 181-201. Durham: Duke University Press.

University and College Union. 2016a. Workload Is an Education Issue: UCU Workload Survey Report 2016. London: University and College Union. Accessed 11 January 2018. https://www.ucu.org.uk/media/8195/Workload-is-an-education-issue-UCU-workloadsurvey-report-2016/pdf/ucu workloadsurvey fullreport jun16.pdf

University and College Union. 2016b. HE Rate for the Job. Accessed April 21, 2016. https://www.ucu.org.uk/article/8087/HE-rate-for-the-job

University and College Union. 2016c. When Is a Pay Rise Not a Pay Rise? Accessed April 21, 2016. https://www.ucu.org.uk/when-is-a-pay-rise-not-a-payrise?utm source=campaignupdate. allmembers\&utm medium=email\&utm campaign=lyrUCU+campaigns+update:+18+March+2016\&utm term=SC004

University and College Union. 2014. UCU Survey of Work-Related Stress. London: University and College Union. Accessed 11 January 2018. https://www.ucu.org.uk/media/6908/UCU-survey-of-work-related-stress-2014---summaryof-findings-Nov-14/pdf/ucu stresssurvey14 summary.pdf

University of Edinburgh. 2016. What Is Online Learning? Accessed July 19, 2017. http://www.ed.ac.uk/studying/postgraduate/degree-guide/online-learning/about

van Dyk, Silke and Tilman Reitz. 2016. Projektförmige Polis und akademische Prekarität im universitären Feudalsystem (Teil 1). SozBlog. Blog der Deutschen Gesellschaft für 
Soziologie, June 9. Accessed 11 January 2018. http://soziologie.de/blog/2016/06/projektfoermige-polis-und-refeudalisierung

van Mourik Broekman, Pauline, Gary Hall, Ted Byfield, Shaun Hides and Simon Worthington. 2015. Open Education: A Study in Disruption. London: Rowman \& Littlefield Publishers.

Watts, Jenny and Noelle Robertson. 2011. Burnout in University Teaching Staff: A Systematic Literature Review. Educational Research 53 (1): 33-50.

Werry, Chris. 2002. The Rhetoric of Commercial Online Education. Workplace: A Journal for Academic Labor 9: 34-44. Accessed 11 January 2018. http://ices.library.ubc.ca/index.php/workplace/article/view/184045

Willmott, Hugh. 1995. Managing the Academics: Commodification and Control in the Development of University Education in the UK. Human Relations 48 (9): 993-1027.

Winn, Joss. 2015. Writing About Academic Labour. Workplace: A Journal for Academic Labor 25: 1-15. Accessed 11 January 2018. http://ices.library.ubc.ca/index.php/workplace/article/view/185095

Winn, Joss. 2012. Open Education: From the Freedom of Things to the Freedom of People. In Towards Teaching in Public: Reshaping the Modern University, edited by Mike Neary, Howard Stevenson and Les Bell, 133-147. London: Continuum.

Wright, Erik Olin. 2010. Envisioning Real Utopias. London: Verso Books.

Wright, Erik Olin. 1997. Class Counts: Comparative Studies in Class Analysis. Cambridge: Cambridge University Press.

Wright, Erik Olin. 1978. Class, Crisis and the State. London: Verso Books.

Wright, Steve. 2002. Storming Heaven: Class Composition and Struggle in Italian Autonomist Marxism. London: Pluto Press.

\section{About the Author}

Thomas Allmer

Thomas Allmer is Lecturer in Digital Media at the University of Stirling, Scotland, UK, and a member of the Unified Theory of Information Research Group, Austria. His publications include Towards a Critical Theory of Surveillance in Informational Capitalism (Peter Lang, 2012) and Critical Theory and Social Media: Between Emancipation and Commodification (Routledge, 2015). For further information, please see: http://allmer.uti.at 


\title{
University Transformations and the New Knowledge Produc- tion Regime in Informational Capitalism
}

\author{
Maxime Ouellet* and Éric Martin** \\ *École des médias, Université du Québec à Montréal, Montreal, Canada, ouel- \\ let.maxime@uqam.ca
}

**Department of Philosophy, Cégep Édouard-Montpetit, Longueuil, Canada, eric.martin@cegepmontpetit.ca

\begin{abstract}
This article examines undergoing transformations in universities in the context of the structural crisis of capitalism, which began more than 40 years ago. This crisis is at the heart of one of the main contradictions of capitalism: while capital needs living labour to produce value, the dynamic of accumulation requires the replacement of human labour by machines. We will show how capital attempts to overcome this contradiction by modifying the nature of knowledge, learning institutions and human beings to turn them into productive investments, whose profitability can be measured. The contemporary mutations of universities are linked to the globalization, financialization and commodification of knowledge. We also observe transformations in universities' institutional arrangements and in individual human consciousness. Our perspective combines institutionalist political economy and Marxian critique of value, showing how material, institutional and cultural transformations are dialectically articulated in a new form of social regulation. We will show how there is a complementarity between the transformations of political, economic and learning institutions and their linkage with a new mode of knowledge production. The general goal being that advanced mastery of knowledge and information will increase the efficiency of the technological and economic system and its endless acceleration.
\end{abstract}

Keywords: Informational Capitalism, Value Theory, University, Globalization, Financialization, Commodification of Knowledge

The purpose of this article is to analyse ongoing transformations within higher learning institutions in the context of the structural crisis that has plagued capitalism in the last 40 years. This crisis is at the heart of one of the main contradictions of capitalism: while capital needs living labour to produce value, the dynamic of accumulation requires the replacement of human labour by machines (Postone 1999; McChesney and Nichols 2016). We will show how capital seeks to overcome this contradiction by altering the nature of knowledge and human beings to transform them into productive investments whose profitability can be measured. We will show how the mutations of contemporary capitalism, described by some as informational (Castells 1996) or as cognitive capitalism (Hardt and Negri 2000), characterised by globalization, financialisation and the commodification of knowledge, are linked to institutional transformations within universities and changes in human consciousness. From a perspective combining both the institutionalist political economy (Mirowski 2011) and the Marxist critique of value (Postone 1993), we will see how material, institutional and cultural transformations are dialectically articulated within a new mode of social regulation. It is important to describe the complementarity between transformations of political, economic and educational institutions, as well as their common belonging to a 
new mode of production of knowledge. It is therefore essential to understand the political nature of these institutional transformations to grasp their ideological basis, which originated in the neoliberal cultural revolution. This 'revolution' consists in conceptualizing economic agents as information processors and the market as a cybernetic mechanism of transmission of information (Ouellet 2016).

First, we will develop a dialectical approach (of Hegelian-Marxian inspiration) to understand the contemporary university, as to avoid the pitfalls of previous critical theories, namely traditional Marxism or postmodern thinking. The second step is to grasp the university's becoming in the context of the structural transformations of late capitalism. Thirdly, we will present the epistemological groundings of the new neoliberal regime of knowledge production, and finally see how it is dialectically articulated with cultural and institutional transformations of universities within informational and globalized capitalism.

\section{Towards a Dialectical and Critical Theory of the University}

Traditional critical theories in the sociology of education field have generally emphasized the role of academic institutions as a mechanism bent on the reproduction of social inequalities. For example, according to Baudelot and Establet, who can be classified as Althusserian-inspired structural-Marxism, it is necessary to criticize the "capitalist school" as an ideological state apparatus responsible for the reproduction of dominant classes (Baudelot and Establet 1971) ${ }^{1}$. Similarly, for Bourdieu and Passeron, education produces symbolic violence and assigns each individual a place in the social field, thus reproducing class habitus (Bourdieu and Passeron 1990). Although relevant, these theories are insufficient in that they are ahistorical and do not account for the systemic transformations, linked to the contemporary mutations of capitalism, that now affect the university. Indeed, they are mainly interested in thinking of schools as an instrument of reproduction of class division. This prevents them from thinking positively of the university ${ }^{2}$ as being initially thought of as a central institution or mediation in the emancipatory project of modernity, grounded in reason. This means thinking of the university as a public sphere ${ }^{3}$, that is, as an institution whose ideal entails the critical discussion between reflective subjects (Giroux 2011). This is why a dialectical approach to the changes of the university, with regard to the

${ }^{1}$ A similar approach can be found in Bowles and Gintis 1976.

2 We refer not to the empirical university, but to the ideal-type of this institution and how it was thought in the modern project. See Freitag (1998).

${ }^{3}$ In saying this, we are not taking a Habermasian stance. We recognise that there are inherent contradictions in the bourgeois subjectivity (which, as Marx pointed out in On the Jewish Question (1844), is ripped apart by an abstract universal ideal of the autonomous citizen and the concrete selfish homo economicus of capitalist social relations). The modern university is also contradictory. It thinks of itself as an ideal public sphere, but it is plagued with contradictions which tend to submit academic freedom to capitalist demands. The problem with the neoliberal university is that it tends to suppress this inner contradiction by openly destroying the traditional ideal mission of the university in the name of immediate adaptation to the organisations of globalized informational capitalism. With Boltanski and Chiapello (1999), we could talk of a new spirit of academic capitalism. In 1968, the artistic critique of the radical students demanded a more horizontal university. As we well show below, post1968 universities integrated this critique by suppressing any vertical reference to their constitutive ideal and adapting horizontally to anything that surrounded them, that is, customers and, especially, economic organisations. 
structural transformations of capitalism, proves necessary today. As Ernest Mandel stressed in the 1970s:

The main task of the university is no longer to produce 'educated' men of judgment and property - an ideal which corresponded to the needs of freely competitive capitalism - but to produce intellectually skilled wage earners for the production and circulation of commodities (Mandel 1975, 262).

The Hegelian Idea, in which reason was to be the motor of historical development, has been subverted: the valorisation of capital replaced reason and became the new Geist, the new substance-as-subject (Postone 1993). Similarly, the modern university of reason ${ }^{4}$ has now become the university of capitalist unreason. After the crisis of Marxism, in the late 1970s and early 1980s, postmodern thought emerged (Lyotard 1984). This new, non-dialectical approach does take note of the colonization of the university by the system, but considers it as inevitable in the era of the 'end of grand narratives'.

Since the institution - initially dedicated to seeking universality and truth - has been absorbed by the system, critical people can only, according to a postmodern perspective, rely on defending particularity or seek refuge in transgressive language games to resist or try to outfox capitalism, without any hope of ever actually transforming it (Readings 1997). These approaches abandon any reference to reason and truth, which then become synonymous with capitalism, and fall back upon the defense of the infinite plurality of discourses.

Moreover, the postmodern left has provided the privatization of knowledge with academic legitimacy by deconstructing the idea of science as a public good. Indeed, according to economic historian Philip Mirowski, the actor-network theory developed by Michel Callon and Bruno Latour (Callon 1988) played a role in the legitimation for the privatization of knowledge in American universities. According to Callon and Latour, nothing in science prevents it from being transformed into a commodity, as Philip Mirowski notes, quoting Michel Callon:

"[...] there is nothing in science that prevents it from being transformed into a merchandise". Because nonexclusion was reportedly not proving to be such a problem, and nonrivalry did not really exist in science, "scientific knowledge does not constitute a public good as defined by economic theory". Far from economists politically displacing sociologists, it seems neoliberalism had taken root in the most avant-garde precincts of science studies, gussied up with

\footnotetext{
${ }^{4}$ This does not mean that we should only seek to save modern reason from the unreason of capital. Indeed, as Adorno and Horkheimer (2002) well understood, we must develop a critique of the bourgeois and instrumental understanding of reason that dominated modernity, in that it is linked to the market form of social relations. This critique, as we shall argue, must not be carried out in the name of postmodern irrationalism or anti-foundationalism, but in order to save reason from its own pitfalls, relying not only on its negative critical moment, but also and as an essential means of thinking the need for roots in the positivity of the concrete world.
} 
the seemingly non economic terminology of actants, rhizomes, networks and parliament of things (Mirowski 2011, 66).

Anti-universalism, anti-humanism and anti-essentialism, which are the foundations of postmodern relativistic epistemology, are part of a new social ontology that expresses itself as much in dominant neo-liberalism as in the theoretical discourse of the postmodern left (Mirowski 2013). Current "critical" research that insists on the subjective resistance of actors or identities while rejecting any possibility of analysing society as totality, reproduces the ontological foundations of neoliberal practice in the field of pseudo-critical theory. This is a good illustration of the hegemony of neoliberalism: the inability to 'think outside the box' or frame of dominating forms of representation. This is why it is necessary to re-articulate a Hegelian-Marxian critique of the university, which should, following Adorno and Horkheimer (2002), think of itself as a dialectic of reason.

Traditional Marxist ${ }^{5}$ approaches understand knowledge in predominantly instrumental terms. Capitalism no longer treats knowledge as a means of access to truth, but merely as a factor of production and valorisation. Pseudo-critical approaches are incapable of considering the dialectical relationship between forms of social relations and forms of knowledge. They are mainly interested in criticizing class relations, and thus mainly consider the distribution of knowledge as a variable one can use to explain social differentiation or the distribution of "symbolic capital" (Bourdieu and Passeron 1990). Postmodern approaches go even further by separating knowledge and truth, and reducing all discourses to moves in a power game. Rather, we believe that forms of subjectivity, knowledge, culture and social relations should be considered as being part of a "relation of objectification"6 (Freitag 2002). That is, a type of society has a given moment in history, is structured, as a whole, by specific forms of culturalsymbolic and political-institutional mediations. These mediations shape the form of subjectivities, the type of knowledge or culture, the type of institution, and the type of social relationship that will prevail in that given form of society. According to Lukàcs (1975), one cannot understand the reified relation to knowledge, reduced to instrumental reason, and to the institution that is university without developing a theoretical understanding of the social mediations that are specific to the capitalist form of society.

Our approach (Martin and Ouellet 2014), based on the "radical critique of value" (Wertkritik) (Larsen et al. 2014), undertakes a categorial critique of capitalist domination in order to go beyond the limits of postmodern approaches, which merely pit the particular against the universal, but also the limits of traditional Marxist approaches whose analysis of capitalism is mainly centred on class relations. According to our approach, categories of thought are also categories of social practice and are determined by forms of mediation specific to a given type of society. Knowledge, institutions and the forms of social objectivity and subjectivity are all mediated by the social totality. In the same way, in order to criticize the contemporary university - the conception of knowledge which prevails inside it, and the subjectivities who inhabit it more attention must be paid to the manner in which these subjects and objects are

${ }^{5}$ On the distinction between traditional and critical Marxism, see Postone (1993).

${ }^{6}$ According to Freitag (2002), the objectification relation is understood in Hegelian terms as (S-m-O), where both the subject and the object are shaped by the mediation, itself understood as a moment of social totality. 
determined by the form of social mediation, and the relation between this form of mediation and late capitalism understood as a whole or totality.

This is why the capitalist university and the instrumental or utilitarian knowledge it produces cannot be understood outside of a historical sociology which seeks to explain the failure of the modern project and the advent of a society dominated by commodity fetishism, whose triumph means the entry into postmodernity, an era dominated by informational capitalism. The modern university was conceived in ideal terms as an institution dedicated to Bildung, allowing society to reflect critically on itself, as part of a wider democratic, public and political sphere. Our work shows how this institution is gradually becoming an organisation ${ }^{7}$, serving the reproduction of the advanced capitalist system, dominated by techno-science and cybernetic thought. The university no longer ${ }^{8}$ serves the democratic project or the "self-institution of society" (Castoriadis 1997); it is now thought of only as a hub for technological innovation useful for the valorisation of capital.

In this perspective, we can understand how certain forms of subjectivity, conceptions of knowledge or institutions (in particular universities), as well as theoretical trends, may emerge or disappear according to changes in the dominant or overarching forms of social mediation. Following critical neo-Gramscian theorists (Cox 1987), it is possible to argue that there is a dialectical interrelation between the predominant modes of economic production, institutions, forms of human consciousness or dominant theories in academia, and the type of subjectivity that is hegemonic at a given time. As we will argue below, it is therefore necessary to historicize theoretical production itself insofar as it expresses a specific social form and a specific historical moment.

\section{The Transformations of the University in Late Capitalism}

In order to grasp the transformations of the university in the context of informational capitalism, it is first necessary to grasp the fundamental changes that have taken place within economic institutions in the era of late capitalism. The corporation, which is characterised by the separation of control and ownership, replaces the classical figure of the bourgeois who owns the means of production, and becomes the main institution within the capitalist mode of production (Berle and Means 1968). According to Baran and Sweezy, this institutional transformation was insufficiently taken into account by Marxist economists. This requires a reformulation of Marx's original framework of analysis, designed in the context of liberal capitalism where the market was the main form of central mediation (Baran and Sweezy 1966). The rising of the

\footnotetext{
${ }^{7}$ An institution is governed by a reflective purpose that aims for an ideal (a university should transmit culture, for example) whereas an organisation is merely an aggregate of individuals who aim to maximize efficiency in order to reproduce and extend the reign of this same organisation (for example, a capitalist corporation). See Freitag (1998).

8 This doesn't imply the empirical university actually ever did serve such a purpose. We are here comparing the modern ideal of the university with its current ruin. We are not therefore suggesting the Fordist university is the model we should go back to. Indeed, the Fordist university, although it had in some cases a relative autonomy from the market, was in fact, in general terms, already seen by large economic institutions like the OECD as a means to increase national production (see Papadopoulos 1994). The relative autonomy we are referring to disappears in the neoliberal university. For example, STEM (Science, technology, engineering and management) sectors were already well embedded in the capitalist accumulation process in the capitalist era. Now, humanities are also being integrated in the socalled 'creative economy'. See Jessop (2017).
} 
organic composition of capital, which leads to the tendency of the rate of profit to fall, was replaced by the more perilous problem of overproduction induced by intercapitalist competition. Planned obsolescence, advertising and marketing then all appear as necessary mechanisms to absorb the excess of surplus-value within a deeply irrational mode of development. The development of the financial, insurance and real estate sectors, as well as the mass media (Smythe 1977), also became important industrial sectors employing an increasing mass of workers to compensate the contradictions of capital.

The discourse on 'knowledge-based economy', the very basis for contemporary theses on informational capitalism, finds some of its origins in the "managerial revolution" (Burnham 1960), although the exact expression was not yet used at that time. The rise of the managerial class is made possible by dispossessing workers of their know-how, and the latter recodification of this knowledge by the bureaucratic apparatus of the capitalist enterprise, under the aegis of the scientific management of labour initiated by Taylor (Braverman 1974). The role of this techno-structure was to put a maximum quantity of information in circulation, so as to make the most efficient decisions (Galbraith 1967).

In the Fordist context, the university and the education system occupy a central place (Noble 1977). Contrary to what the strictly negative critics claim (Althusser 1976; Bourdieu and Passeron 1990), schools are not merely an instance of reproduction of class domination. The relationship between the state, university and corporation, far from corresponding to their current fusion in the neoliberal regime, still depended on a relative autonomy being granted to educational institutions.

From a political point of view, the massive entry of students into universities in the post-war era occurs in the context of a capital-labour compromise and its institutionalization in the American New Deal (Cohen 2003). The democratization/massification of higher education is part of the extension of certain social rights which form the basis of the welfare state (Marshall 1963). Indeed, the democratization of higher education can be understood as the result of a struggle for wider access to education. But this reform, from the point of view of capital, was also necessary to maintain the dynamics of value-production and to produce a type of individual adapted to the logic of overconsumption/overproduction of the Fordist era. This mode of regulation was also characterised by the explosion of the services sector, which was dependent on the advances of the welfare state and the bureaucratization of public and private organisations.

It also allowed for the formation of a middle class made up of professional managers (Bell 1973). In addition to the technical sectors directly related to capitalist accumulation, such as industrial engineering, social sciences developed at that time in American universities, notably thanks to the philanthropic funding of private foundations (for example, the Rockefeller, Carnegie and Ford foundations). The philanthropic funding of social sciences was more specifically aimed at depoliticizing their subversive potential by promoting the use of empiricist methods. Administrative 'sciences', especially marketing and management, formed the basis of a technocratic science that could increase the possibilities of social control (Noble 1977).

The Fordist era mass university was producing technocrats who would orchestrate national development, relying in particular on the positivist scientific ideas of the time. Still, the university enjoyed a relative autonomy based on a conception of knowledge as a public good. This maintained a certain type of distance between academic research and the corporation. As Mirowski points out, during the Cold War, the academic research was thought of as being performed in a nationalized system by self- 
less professors valuing integrity, taking pride in academic freedom and displaying somewhat of a disdain for the market:

It was only within the Cold War regime that "academic freedom" became invested with sufficient gravitas to actually be deployed in an effective defense of the system of academic tenure - something we can now appreciate in the era of its disappearance. The researcher was said to have only to answer to his disciplinary peers, or in the last instance, to his individual conscience, and to feel an enlightened disdain for the hurly-burly of the marketplace at least until the DARPA grants officer came to call (Mirowski 2011, 114).

This understanding of knowledge, shared at the time by the majority of economists, can explain the hegemony of the Keynesian paradigm and its synthesis with the neoclassical school, as formulated by economist Paul Samuelson (Dostaler and Beaud 1995). In fact, the positivist Marxist conception of labour-value and the developmental paradigm belong to the same social imaginary as the social engineering promulgated by the synthesis between Keynesianism and neo-classical doctrine. Looking at ideas and thinking, hegemony is to be found in the common aim shared by all these doctrines: to stimulate effective demand through the recognition of the value of work and the increase in the purchasing power of consumers.

\section{The Commodification of Information and the New Knowledge Production Re- gime in Globalized Informational Capitalism}

The crisis of Fordism on the global scale at the turn of the 1970s resulted in a restructuring of the dialectical articulation between the productive forces, institutions and subjective forms of human consciousness (Cox 1987). The traditional explanation of this period finds the reason for the restructuring of the capitalist world order in the new hegemony of neoliberal ideas (Rupert 2000). This analysis does not, in our view, adequately explain the nature of the neoliberal project. In this section, we will outline the constitutive dialectic of the neoliberal university, that is, the mediation between its particular conception of knowledge and its general institutionalization in the new globalized system of privatized knowledge.

The traditional critique of neoliberalism describes this philosophy as a return to a certain form of classical liberalism and its doctrine of laissez-faire. This superficial reading does not allow a real understanding of the essence of neoliberalism, which institutes a paradigmatic revolution transforming the classical liberal conception of the market. Indeed, neoliberalism re-defines the market as a cybernetic system that transmits information to economic agents, who are themselves thought of as information processors (Mirowski 2013). According to neoliberals, it is impossible for a subject to know all the information held by other particular individuals. That is why the market is considered superior to planning. In the neoliberal conception, knowledge cannot be assimilated to a public good. It is rather a commodity like any other, whose value comes from the fact that it makes it possible to reduce the uncertainties coming from a hyper-complex world, whose totality cannot be known or understood by any subject.

The paradigmatic market revolution understood as a cybernetic system of information transmission was first outlined by Hayek in an article entitled, "The Use of 
Knowledge in Society" (Hayek 1945). This text, a sort of manifesto for knowledge economy, prefigures postmodernity, in so far as it already announces the fall of reason and its inability to synthetically grasp reality (for example, the crisis of grand narratives in Lyotard). The neo-liberal epistemological revolution then went on to be an inspiration for public policies in the majority of industrialized countries, notably pertaining to research financing. These policies were particularly inspired by a World Bank consultant, Michael Gibbons, who argues that in the knowledge-based economy, the "mode of production" of knowledge must be transformed. Traditional knowledge was produced in universities according to a model called "hierarchical", based on a debate within the scientific community to evaluate the validity of knowledge on the basis of a truth criterion. The new "mode of production of knowledge" (or 'Mode 2') advocates de-hierarchizing the production of knowledge insofar as it is no longer the scientific community that must judge the validity of knowledge. It is rather the ability of knowledge to find a practical application in the external environment (i.e. the economy) that becomes the criterion determining their validation (Gibbons et al. 1994).

From the 1970s onwards, the cybernetic conception of the market, picked up by most neoclassical economists, became the dominant paradigm in "economic science" (Mirowski 2000). The subjectivist theory of value understood as liquidity, which is at the basis of the speculative mechanisms of price formation in the market sphere in the present financialized capitalism, corresponds, from an epistemological point of view, with the equally subjectivist and post-modern theories marked by antifoundationalism, anti-essentialism, and anti-universalism. Indeed, the marketefficiency theory (Bryan and Rafferty 2013), the basis for the evaluation of derivative products in financial markets, argues that the value of a security on the stock exchange reflects the information possessed by economic actors. In this sense, contemporary theories on "digital labor" (Fuchs 2013) must be related to the current system of financial accumulation (Ouellet 2015). In a context of increased economic risks associated with uncertainty in a global financial universe, new, more complex and abstract financial products such as derivatives have been created. In financialized capitalism, risk in fact becomes a new form of social mediation. Based on information and digitized financial data (Manzerolle and Kjøsen 2012), risk is linked to the mediation of social relations by abstract labour. In the same way that the exchange of any commodity is based on the abstraction of labour, the possibility of exchanging derived products stems from the abstraction of the specificity of a multitude of particular risks, which, in their very essence, are in fact immeasurable. The abstracted risk is subsequently taken to be measurable and decomposable into homogeneous units that can thereafter be traded on financial markets (Lipuma and Lee 2005).

Thus, in advanced capitalist societies, there is a profound change in the way in which social reproduction takes place, a transformation, which also affects the subjectivity of the actors operating within universities. In the context of so-called informational capitalism, social reproduction no longer relies solely on the relationship of wage domination, but rests largely on the existence of credit. This does not mean that work as a central form of social mediation and domination has disappeared, but rather that its role is transformed. Employment now has the primary function of obtaining a minimum wage to acquire sufficient financial credibility in order to access credit and repay a portion of one's debt. Reproduction of the labour force thus becomes itself a source of surplus value, since this surplus value is now captured before entering the relationship of wage domination (Bryan et al. 2009). This surplusvalue takes the form of an annuity capital manages to skim from the monthly repay- 
ment of the debt of employees and students. In this context, the individual is forced to act as an entrepreneur-of-himself who manages his risk level in a context of widespread financial insecurity. This imposed management of financial risk ensures that human beings themselves become and act as a form of capital, as in the theory of human capital (Becker 1964). This ideology serves as justification for the neoliberal conception of the entrepreneurial subject. Moreover, the concept of the individual, who manages her/his risks as a business, standardizes the use of student debt under the false pretence that students will be able to reap larger future income streams by investing more in their human "capital" (Martin and Ouellet 2011). This institutional complementarity between knowledge and finance risks, according to some economists, is creating a new speculative bubble threatening to burst: the "student debt bubble" (The Economist 2011).

The hegemony of the neo-liberal conceptualization of knowledge must be understood in the context of the crisis of the predominant institutional form in late capitalism, that is, the corporation. In addition to being characterised by the separation of ownership and control, it is based on a new conception of property which is defined by its intangibility (Bichler and Nitzan 2009). Intangible assets are the immaterial assets of businesses that allow them to harvest future revenue streams through a monopoly market control strategy (patents, trademarks, agreements with other corporations, or with governments). In a failing Fordist accumulation regime, the strategy for reviving American corporations was, on the one hand, to redeploy its activities by developing their intangible capital and, on the other hand, to subcontract industrial production to developing countries.

In a context where financial markets demand rapid returns, firms have adopted a range of management techniques such as competitive engineering, subcontracting, downsizing, teamwork, decentralization, and so on. The pyramidal and hierarchical business has been replaced by the networked firm, whose components are constantly reinventing themselves in response to market demands. The strategy chosen to overcome the crisis of the Fordist mode of regulation was thus to transform the firm into a cybernetic organisation. This transformation has enabled the company to grow its image-capital by aiming communication flows towards its shareholders (projecting a financial image), employees (internal image), consumers (brand image) and citizens (the civic image) (Mattelart 1991). This communication strategy was also a response to criticism of the hierarchical structure in the Fordist mode of regulation, seen as an obstacle to the liberation of individual capacities (Boltanski and Chiapello 1999).

This major restructuring within corporations coincides with a crisis in the education sector characterised by a decrease in student enrolment and a withdrawal of public funding from universities. To mitigate this decline in public funding, the solution advocated by many universities will be to link them more closely with businesses (Slaughter and Leslie 1999). In the context of rising demands for shareholder value, companies asked to generate short-term returns will see universities as a privileged place to outsource their research and development departments. As R \& D investments are deemed too risky, the new strategy lies in offloading financial risk on public research and privatizing profits in the form of patents. These patents in turn make it possible to generate value from intangible capital in the stock market (Mouhoud and Plihon 2009).

The new global knowledge production regime is intimately linked to the restructuring of the corporation and the university following the crisis of the Fordist regime. 
Based on the open science ${ }^{9}$ principle of the Fordist regime, the intellectual property rights regime was radically transformed in the United States when the Bay-Dohle Act was passed in 1980 (Mirowski 2011). This law allowed the granting of patents and the commercialization of publicly funded research developed in American universities. The Bay-Dohle act also made possible an extension of intellectual property rights in new fields where commercial monopoly was traditionally forbidden in the name of open science, for example information technology or the study of living beings (Zeller 2008).

Moreover, intellectual property rights are closely linked to the knowledge economy and to the financialization of capitalism. Financial capital extracts value from social activity in general, for example in digital labour. The norm of shareholder value which requires a steady increase in profitability - imposes its rentier logic on knowledge, which becomes a key sector of capitalist accumulation (Vercelonne 2004). High-tech firms, whose profits rarely match their market capitalization, accumulate capital in the form of intangible assets generated by intellectual property rights. This monopolization of knowledge is at the heart of the privatized intellectual property rights regime and allows financial capital to extend the appropriation of social production in a renewed form of primitive accumulation (Harvey 2003).

As noted by Orsi and Coriat, the predominantly financial accumulation regime stems from an institutional complementarity between deregulation in the fields of knowledge and finance (Orsi and Coriat 2006). In the 1980s, financial deregulation allowed loss-making firms that had revenues from their intangible assets - primarily generated by intellectual property rights - to enter the stock market. In addition, the deregulation of the rules governing pension funds allowed them to invest in high risk markets, a practice previously prohibited by Prudent Man Law. The introduction of the liquidity of these pension funds in risky markets has thus contributed to the expansion of the financial bubble of the "new economy", in which new firms (Oracle, Google and Yahoo) then appeared (Orsi and Coriat 2006). The new globalized production regime has spread globally and has become institutionalized with the ratification of trade-related intellectual property rights (TRIPS) at the WTO in 1994. This is the first general agreement that deals with communication, information, finance and knowledge sectors as global trade issues (May 2000). This agreement has institutionalized the logic of exploitation specific to "digital labour" on a global scale, as it legalizes the separation between the producer of information and the holder of the means of production.

\section{The Neoliberal Restructuration of the University and the Transformation of the Academic Subjectivity}

The objective changes we identify in the academic sector stem from a change in the overarching social mediations, which organise society understood as a totality. This also implies a change in the subjective form that will be produced socially as well as by the university. The modern university participated in a politico-institutional mode of reproduction of society (Freitag 1998; 2002). Since then, societies have mutated in the direction of a new mode of reproduction dominated by self-reproducing systems. To make things short, we can call this mode "postmodernity", understood as Jameson says, as the "cultural logic of late capitalism" (Jameson 1991).

${ }^{9}$ According to science sociologist Robert K. Merton (1942) the ethos of open science has the following characteristics: communalism (management of science as a public good), universalism, moral integrity, selflessness, organised sceptical thinking. 
Each mode of production and social reproduction is characterised by a specific form of social mediation and by a specific type of technical mediation (Innis 1950). It is therefore problematic to purport technology could be neutral. Just as Marx understood machinery as the specifically capitalist type of technology, we argue that digital technology is the specific form of globalized neoliberal informational capitalism (Ouellet 2016). Initial observers of this transformation, like Lyotard (1984), failed to see the dramatic implications of this change and naively celebrated the democratic potential of computers and free access to databases ${ }^{10}$. Alas, they were blinded to the fact that the new digital (Hassan 2017) and virtual university (Robins and Webster 2003) were in fact specific institutional expressions of the neoliberal transformation of society and were also producing new entrepreneur-subjects adapted to this dynamic (Bissonnette and Laval 2017). Postmodern enthusiasts such as Lyotard failed to see that the new technology itself was an expression of capitalist alienation and thus participated in the propagation of the new ideology of legitimation of capitalism by entertaining false hopes that this technology could be used to build a new domination-free world (Barbrook and Cameron 1996).

Reality was much less romantic. In an attempt to respond to the crisis of Fordism and the ensuing "great devaluation" (Lohoff and Trenkle 2014), the transnational capitalist class (Sklair 1991) tried to use knowledge to catalyse and stimulate technological innovation and the valuation of capital. The link between university and corporations is institutionalized with the introduction of new governance measures inspired by the business sector (Martin and Ouellet 2012), although with a notable difference: in the corporation, managers sought to establish pseudo-horizontal forms of decisionmaking, whereas in the university, traditional collegiality between teachers is replaced by vertical, hierarchical and authoritarian forms which concentrate the executive power at the pyramid's summit. In globalized capitalism, the classical, or even Fordist, institutional model of the university, considered too sluggish to adapt to the new economy, is to be replaced by new "agile" universities (Gillies 2011) who are expected to be hyper-reactive, capable of adapting and anticipating changes in the systemic technical and economic environment. In return, commodified knowledge is called upon to lubricate the process of valuation, to create new technologies in the 'edge' sectors (biotechnology, communication, artificial intelligence, nanotechnology, etc.). These institutional transformations, linked to capitalist globalization, lead to the creation of a similarly "globalized university" (Martin 2016). They also imply changes in the very definition of knowledge, as well as the production of subjectivities (professors, students, etc.) that are now expected to act in the university as entrepreneurs managing their own human capital or as consumers of skills. This transformation of the status of knowledge is clearly illustrated in the new dynamics of Big Data, which leads to the alienation of all know-how, skills and theoretical knowledge, and therefore to generalized proletarianization (Stiegler 2012). According to Chris Andersen (2008):

This is a world where massive amounts of data and applied mathematics replace every other tool that might be brought to bear. Out with every theory of human behavior, from linguistics to sociology. Forget taxonomy, ontology, and psychology. Who knows why people do what they

${ }^{10}$ Even now, some contemporary critics such as Gary Hall (2016) seek to use these technologies to invent new economic models through 'affirmative disruption'. 
do? The point is they do it, and we can track and measure it with unprecedented fidelity. With enough data, the numbers speak for themselves.

In the same way as it profoundly modifies the role of the former welfare state of Fordism, educational neoliberalism transforms the internal "DNA" of the university (Christensen and Eyring 2011). This new system of normativity and its ideological discourse of justification is disseminated by the World Bank and the Organization for Economic Cooperation and Development (OECD). The aim of these transformations is to take the institutional model of the university, understood as a public service geared (at least in principle) towards the idea of the "common good" within a collectivity, and replace it by a new "university-organization" (Freitag 1995). The new University Inc. is post-national, connected to other corporate organisations and dominated by private interests: interests of industry actors, student-consumers, professorsentrepreneurs, families wanting to reproduce their class position, etc. The concept of "internationalization" seems to refer to international cooperation (i.e. helping third world children). Indeed, it rather signifies that the criteria for what is considered a relevant production of knowledge will now be dictated by the new "higher education global market" which is being set up. As Michael Gibbons points out: "Relevance is going to become something that will need to be demonstrated, not just once but on an ongoing basis. Economic imperatives will sweep all before it and "if the universities do not adapt, they will be by-passed" (Gibbons 1997, 2). This could lead to complete university privatization (market model), publicly financed institutions functioning with market mechanisms (quasi-market model) or a mix of both private and public "providers" in interplay, as currently projected in the UK.

\subsection{The World-Class University}

University rankings are pushing universities around the world towards a conformist behaviour, in favour of imitating what the World Bank calls the "world-class university" (Salmi 2009). Everywhere, universities are forced to abandon their traditional form to copy British or American elite universities, known as 'research-intensive', which are always peculiarly positioned at the top of said rankings.

The new globalized universities are thought of as sluggish organisations in need of a major internal restructuring in order to concentrate their resources on excellence niches, enabling them to succeed in the new cross-border (denationalized) and commodified education market, where non-profit actors will compete with new forprofit providers, all thanks to free trade agreements on the commercialization of services (OECD and World Bank 2007). The university is no longer understood as a national public institution, but as a transnational bureaucratic organisation (Readings 1997).

The denationalization (Friedman 2002) of the universities is also based on the promotion of computerized and virtualized "disruption technology" (Christensen and Eyring 2011), that is Massive Open Online Courses (MOOCs), in what could be named a movement of Uberization of the university ${ }^{11}$. Competition in a new borderless market means that smaller institutions and/or those located on the outskirts of major centres will be disadvantaged in favour of major research universities in a given country, which will concentrate most of the funding (for example, the Russell

\footnotetext{
${ }^{11}$ See Robert Hassan (2016).
} 
Group in the UK), unless, as we see in France with the COMUE ${ }^{12}$, we engage in mergers between institutions. The myth of the class-blind republican school (already debunked by Baudelot and Establet (1971), who showed how schooling served to reproduce class divisions and capitalist social relations) now leaves room for a transparent and shameless two-tiered education system separating elite and peripheral schools.

\subsection{The Student Customer and the Entrepreneur-Teacher}

Foreign students are now seen as an export sector of the economy. For example, a British ${ }^{13}$ report estimates the "value of UK education exports" at $£ 14,1$ billion (Department for Business, Innovation and Skills 2011). The Minister of Education in 2013, David Willetts, said: "There are few sectors of the UK economy with the capacity to grow and generate earnings as impressive as education" (UK Government 2013). Competition among institutions at the national level is also encouraged, notably through the introduction of the new Teaching Excellence Framework (TEF) and the introduction of private "new providers" into the academic "market" (Cruickshank 2016). Teachers are transformed into providers of skills leading to employment, and student-customers are surveyed to determine their satisfaction. Subsequently, committees, including industry players, will assign a rank (bronze, silver, gold) to each university, which will serve to rank low-cost and elite universities that will then obtain permission to increase their (already high) tuition of $£ 9,000$ (Adams 2015), since they will be able to claim that they produce the best suited "human capital" to please the needs of the economic environment. This implies a higher level of student debt, which also contributes to the redefinition of the student as a customer, since s/he can now argue that s/he pays and gets into debt to be in the classroom, which entitles her/him to demand a certain return on her/his investment in terms of value-formoney. Isn't the customer always right?

Research professors/entrepreneurs are increasingly recruited according to their ability to be international stars, attract clientele and, mainly, research grants. The duration of probation is increased, and in some cases tenure is now even being abolished in order to stimulate research productivity. Shanghai Jai Tong University (Zhang 2014), China, seeks to emulate the North American model and become part of the world-class research universities club. It has introduced new recruitment procedures for professors: one can reach a permanent position after six years under supervision and two evaluations by an international committee. Promotions and salaries are re-evaluated every three years using performance indicators. Some researchers must make up part of their own salary with research grants. By 2018, faculty members who do not fit the new model (for example, those who 'only' teach and do no subsidised research) will have to leave the university or will be reassigned to non-teaching jobs (Martin 2016).

12 The French Communauté d'université et établissements (COMUE) designates a regrouping of several institutions under one common organisational body. Universities can also go further and merge to create larger bodies in order to obtain world-class proportions and secure research grants.

${ }^{13}$ We recognise, with Jessop (2017), the varieties of academic capitalism, we identify a general trend towards the imposition of a unique globalized university model (Laval et al. 2011), inspired by American academic capitalism. This tendency entails projects to increase tuition fees in many localities: Quebec (Martin and Ouellet 2011), Chile (Martin 2011), France (Collectif ACIDES 2015), UK (Cruickshank 2016) etc. It also leads to changes in governance, quality evaluation, pedagogy and to the commodification of research. 
The relevance of a professor's knowledge is no longer measured in terms of scholarly knowledge of a given field, but by its ability to enter in 'partnerships' with the industry in order to transfer knowledge or patents towards businesses (alternatively, the researcher can create his own spinoff company). Changes in governance reduce the power of teachers and increase the power of industry 'partners' in administrative bodies. Teachers are increasingly subject to evaluation and quality assurance mechanisms, new forms of control that value professor-entrepreneur behaviour and marginalize those who 'only' teach. What was once the main function of a university professor is now thought of as inefficient and outdated. Some 'professors' no longer teach at all, as they are too wrapped up in managing their own little research start-up. This, of course, raises concerns about academic freedom, since the professor who fails to be recognised as productive (generating research valued by the system or skills directly connected with employability) eventually risks being ejected from the "organization". Otherwise a university with poor performance ratings could itself be deemed non-efficient and could see its accreditation withdrawn, as is projected in the UK. Uberization, in general, means that previously relatively stable jobs will be technologically disrupted and workers will be thrown into job insecurity. The education sector reproduces this scenario: devaluation of academic work, automation of this work and general alienation of the relation to knowledge (Noble 1997). In the end, academic workers, just like all other workers, will end up as precarious waged slaves for the great tech corporations who are taking over the classroom (Singer 2017).

\section{Conclusion: The Contradictions of Informational Capitalism}

As we have shown in this article, the mutations of informational capitalism have led to the modification of the nature of knowledge and of human beings in order to transform them into productive investments or capital. The transformations of knowledge, academic institutions and academic subjectivities must be analysed dialectically by linking them to material transformations. Without such an articulation, it is difficult to understand how the new mode of social regulation deployed by neoliberalism and financialized informational capitalism. These transformations are insufficiently explained by the traditional critical approaches in the sociology of education, which mainly study schools as a mechanism reproducing class divisions. Postmodern theoretical approaches (Lyotard 1984; Readings 1997) rely on the transgressive fluidity of individual language games (or sheer irrationality) to resist an institution conceived as irremediably colonised by the instrumental rationality of the system.

These theories are insufficient and unsatisfactory. This is why we have argued here in favour of a dialectical and critical theory of the transformations of knowledge and universities, a theory that is capable of linking these transformations to the mutations of late capitalism, the extension of neoliberal rationality and the general tendency of subsuming society (understood as totality) to the mediation of abstract value, commodities, abstract labour and money, criticising these alienated categories of social practice without abandoning the aim of modern reason and the "university principle" (Prado 2009) . As Herbert Marcuse said: "if the abstract character of the refusal is the result of total reification, then the concrete ground for refusal must still exist, for reification is an illusion" (Marcuse 1964, 260). Therefore, alienation must be negated and refused, but the critique of fetishized mediations does not imply a retreat into some irrational subjectivism; it rather stems desire to institute unalienated mediations grounded in what can be salvaged in what Hegel calls the "concrete universal".

Moreover, the most recent economic crisis has shown the limits of the neoliberal accumulation strategy based on mass indebtedness, financial speculation and the 
commodification of knowledge. Capital in crisis desperately seeks new sectors to expand into. According to the transnational elites, the solution to the crisis would be to intensify the ties between universities and corporations in order to accomplish the "fourth industrial revolution" based on the convergence between the physical sciences, digital technology and biology (Schwab 2016). This will further accelerate the contradictions of informational capitalism, which are based on the dialectical interrelationship between the mediations of labour, wealth and value in an economy that is now knowledge-based. Indeed, from a cultural point of view, the neoliberal university rests on fundamentally contradictory reasoning. It is based on a discourse that considers the market as the most effective mechanism for transmitting information, yet it ultimately leads to ignorance (Mirowski 2013, 81). The privatization of knowledge within the neoliberal university thus leads to the dissolution of its founding ideal: educating knowledgeable citizen with sound judgement.

In economic terms, as Marx emphasized in the Grundrisse, increasing technological progress implies that the production of material wealth requires less and less human labour throughout. At the same time, capitalism needs to produce value by mobilizing living labour (Marx 1969, 342). According to a report published by the World Economic Forum, the Fourth Industrial Revolution, propelled by Big Data and the "Internet of Things", will lead to the loss of 5 million jobs within five years (World Economic Forum 2016). According to several experts, the automation of intellectual labour is on the way to create an irresolvable dynamic of technical unemployment if radical political and economic changes are not made in the near future (Smith and Anderson 2014). These radical changes will only be possible if the struggle against the neoliberal shipwrecking of universities within information capitalism is articulated, at the same time, against both "a jobless economy and a citizenless democracy" (McChesney and Nichols 2016).

\section{References}

Adams, Richard. 2015. Government Plan to Allow 'Better' Universities to Raise Fees. The Guardian, November 6. Accessed 13 January 2018. www.theguardian.com/education/2015/nov/06/government-plan-to-allow-betteruniversities-to-raise-fees

Adorno, Theodor W. and Max Horkheimer. 2002. Dialectic of Enlightenment. Stanford: Stanford University Press.

Althusser, Louis. 1976. Positions 1964-1975. Paris: Éditions sociales.

Andersen, Chris. 2008. The End of Theory: The Data Deluge Makes the Scientific Method Obsolete. Wired, August 23. Accessed 13 January 2018. https://www.wired.com/2008/06/pb-theory

Baran, Paul A. and Paul M. Sweezy. 1966. Monopoly Capital: An Essay on the American Economic and Social Order. New York: Monthly Review Press.

Barbrook, Richard and Andy Cameron. 1996. The Californian Ideology. Science as Culture 26 (1): 44-72.

Baudelot, Christian and Roger Establet. 1971. L'école capitaliste en France. Paris: Éditions Maspero.

Becker, Gary. 1964. Human Capital: A Theoretical and Empirical Analysis. Chicago: University of Chicago Press.

Bell, Daniel. 1973. The Coming of Post-Industrial Society: A Venture in Social Forecasting. New York: Basic Books.

Berle, Adolf and Gardner C. Means. 1968. The Modern Corporation and Private Property. New York: Brace \& World. 
Bichler, Shimson and Jonathan Nitzan. 2009. Capital as Power: A Study of Order and Creorder. London: Routledge.

Bissonnette, Jean François and Christian Laval. 2017. Gambling with "Human Capital": On the Speculative Logic of the "Knowledge Economy". World Social and Economic Review of Contemporary Policy Issues 8: 6-17.

Boltanski, Luc and Ėve Chiapello. 1999. Le nouvel esprit du capitalism. Paris: Gallimard.

Bourdieu, Pierre and Jean-Claude Passeron. 1990. Reproduction in Education: Society and Culture. Thousand Oaks: SAGE.

Bowles, Samuel and Herbert Gintis. 1976. Schooling in Capitalist America: Educational Reform and the Contradictions of Economic Life. New York: Basic Books.

Braverman, Harry. 1974. Labor and Monopoly Capital: The Degradation of Work in the Twentieth Century. New York: Monthly Review Press.

Bryan, Dick and Michael Rafferty. 2013. Fundamental Value: A Category in Transformation. Economy and Society 42 (1): 130-153.

Bryan, Dick, Randy Martin, Mike Rafferty. 2009. Financialization and Marx: Giving Labor and Capital a Financial Makeover. Review of Radical Political Economics 41 (4): 458-472.

Burnham, James. 1960. The Managerial Revolution. Bloomington: Indiana University Press.

Callon, Michel. 1988. La Science et ses réseaux. Genèse et circulation des faits scientifiques. Paris: La Découverte.

Castells, Manuel. 1996. The Rise of the Network Society. The Information Age: Economy, Society and Culture, Vol. I. Oxford: Blackwell.

Castoriadis, Cornelius. 1997. The Imaginary Institution of Society. Cambridge: MIT Press.

Christensen, Clayton and Henry Eyring. 2011. The Innovative University: Changing the DNA of Higher Education from the Inside Out. San Francisco: Jossey-Bass.

Cohen, Lizabeth. 2003. A Consumer's Republic: The Politics of Mass Consumption in Postwar America. New York: Knopf.

Collectif ACIDES. 2015. Arrêtons les frais! Pour un enseignement supérieur gratuit et émancipateur. Paris: Raisons d'agir.

Cox, Robert W. 1987. Production, Power and World Order. Social Forces in the Making of History. New York: Columbia University Press.

Cruickshank, Justin. 2016. Putting Business at the Heart of Higher Education: On Neoliberal Interventionism and Audit Culture in UK Universities. Open Library of Humanities 2 (1).

Accessed July 28, 2017. https://olh.openlibhums.org/article/10.16995/olh.77

Department for Business, Innovation and Skills. 2011. Estimating the Value to the UK of Education Exports. London: BIS Research Paper. Accessed July 28, 2017. https://www.gov.uk/government/uploads/system/uploads/attachment data/file/32395/11980-estimating-value-of-education-exports.pdf

Dostaler, Gilles and Michel Beaud. 1995. Economic Thought Since Keynes: A History and Dictionary of Major Economists. Aldershot: Edward Elgar.

Freitag, Michel. 2002. The Dissolution of Society within the 'Social'. European Journal of Social Theory 5 (2): 175-198.

Freitag, Michel. 1998. Le naufrage de l'université et autres essais d'épistémologie politique. Montreal: Éditions Nota Bene.

Friedman, Milton. 2002/1962. Capitalism and Freedom. Chicago: University of Chicago Press.

Fuchs, Christian. 2013. Digital Labour and Karl Marx. New York: Routledge.

Galbraith, John Kenneth. 1967. The New Industrial State. Boston: Houghton Mifflin.

Gibbons, Michael. 1997. Higher Education Relevance in the $21^{\text {st }}$ Century. Washington: World Bank.

Gibbons, Michael, Camille Limoges, Helga Nowotny, Simon Schwartzman, Peter Scott and Martin Trow. 1994. The New Production of Knowledge: The Dynamics of Science and Research in Contemporary Societies. Thousand Oaks: SAGE. 
Gillies, Donald. 2011. Agile Bodies: A New Imperative in Neoliberal Governance. Journal of Education Policy 26 (2): 207-223.

Giroux, Henry A. 2011. Once More, with Conviction: Defending Higher Education as a Public Good. Qui Parle: Critical Humanities and Social Sciences 20 (1): 117-135.

Hall, Gary. 2016. The Uberification of the University. Minneapolis: University of Minnesota Press.

Hardt, Michael and Antonio Negri. 2000. Empire. Cambridge: Harvard University Press.

Harvey, David. 2003. The New Imperialism. New York: Oxford University Press.

Hassan, Robert. 2017. The Worldly Space: The Digital University in Network Time. British Journal of Sociology of Education 38 (1): 72-82.

Hayek, Friedrich. 1945. The Use of Knowledge in Society. American Economic Review 35: 519-530.

Innis, Harold. 1950. Empire and Communications. Oxford: Clarendon Press.

Jameson, Frederic. 1991. Postmodernism, Or, the Cultural Logic of Late Capitalism. Durham: Duke University Press.

Jessop, Bob. 2017. Varieties of Academic Capitalism and Entrepreneurial Universities. Higher Education 73 (6): 853-870.

Larsen, Neil, Mathias Nilges, Josh Robinson and Nicholas Brown, eds. 2014. Marxism and the Critique of Value. Chicago: MCM' Books.

Laval, Christian, Francis Vergne, Pierre Clément and Guy Dreux. 2011. La nouvelle école capitaliste. Paris: La Découverte.

Lipuma, Edward and Benjamin Lee. 2005. Financial Derivatives and the Rise of Circulation. Economy and Society 34 (3): 404-427.

Lohoff, Ernst and Norbert Trenkle. 2014. La grande dévalorisation. Fécamp: Post-éditions.

Lukàcs, György. 1975. History and Class Consciousness. London: Merlin.

Lyotard, Jean-François. 1984. The Postmodern Condition: A Report on Knowledge. Minneapolis: University of Minnesota Press.

Mandel, Ernest. 1975. Late Capitalism. London: Humanities Press.

Manzerolle, Vincent and Atle Mikkola Kjøsen. 2012. The Communication of Capital: Digital Media and the Logic of Acceleration. tripleC 10 (2): 214-229.

Marcuse, Herbert. 1964. One-Dimensional Man: Studies in the Ideology of Advanced Industrial Society. Boston: Beacon Press.

Marshall, T.H. 1963. Class, Citizenship and Social Development. Chicago: Chicago University Press.

Martin, Éric. 2016. L'université globalisée. Transformations institutionnelles et internationalisation de l'enseignement supérieur. Montreal: Institut de recherche et d'informations socio-économiques. Accessed July 28, 2017. http://iris-recherche.qc.ca/publications/udem

Martin, Éric. 2011. La jeunesse chilienne contre l'éducation privée. Montreal: Institut de recherche et d'informations socio-économiques. Accessed July 28, 2017. http://irisrecherche.qc.ca/blogue/la-jeunesse-chilienne-contre-leducation-privee

Martin, Éric and Maxime Ouellet. 2014. La tyrannie de la valeur. Débats pour le renouvellement de la théorie critique. Montreal: Écosociété.

Martin, Éric and Maxime Ouellet. 2012. La gouvernance des universités dans l'économie du savoir: Entre marchandisation et financiarisation. In Leurres de la qualité? edited by Bruno Leclercq, 169-194. Paris: L'Harmattan.

Martin, Éric and Maxime Ouellet. 2011. Université Inc. Mythes à déconstruire sur la hausse des frais de scolarité et l'économie du savoir. Montreal: Lux.

Marx, Karl. 1969. Grundrisse: Fondements de la critique de la critique de l'économie politique, Vol. 3. Paris: Éditions Anthropos.

Marx, Karl. 1844. On the Jewish Question. Accessed July 28, 2017. https://www.marxists.org/archive/marx/works/1844/jewish-question

Mattelart, Armand. 1991. Advertising International: The Privatization of Public Space. New York: Routledge. 
May, Christopher. 2000. A Global Political Economy of Intellectual Property Right: The New Enclosures. London: Routledge.

McChesney, Robert and John Nichols. 2016. People Get Ready: The Fight Against a Jobless Economy and a Citizenless Democracy. New York: Nation Books.

Merton, Robert K. 1942. The Normative Structure of Science. In The Sociology of Science, edited by Robert K. Merton, 267-278. Chicago: The University of Chicago Press.

Mirowski, Philip. 2013. Never Let a Serious Crisis Go to Waste: How Neoliberalism Survived the Financial Meltdown. London: Verso.

Mirowski, Philip. 2011. Science Mart: Privatizing American Science. Cambridge: Harvard University Press.

Mirowski, Philip. 2000. Machine Dreams: How Economics Becomes a Cyborg Science. Cambridge: Cambridge University Press.

Mouhoud, El Mouhoub and Dominique Plihon. 2009. Le savoir et la finance. Paris: La Découverte.

Noble, David. 1998. Digital Diploma Mills. The Automation of Higher Education. First Monday 3 (1). Accessed July 28, 2017. http://journals.uic.edu/ojs/index.php/fm/article/view/569/490

Noble, David. 1977. America By Design: Science, Technology and the Rise of Corporate Capitalism. New York: Alfred A. Knopf.

OECD and World Bank. 2007. Cross-Border Tertiary Education: A Way Towards Capacity Development. Paris: OECD Publications. Accessed July 28, 2017. https://openknowledge.worldbank.org/handle/10986/6865

Orsi, Fabienne and Benjamin Coriat. 2006. The New Role and Status of Intellectual Property Rights in Contemporary Capitalism. Competition \& Change 10(2): 162-179.

Ouellet, Maxime. 2016. La révolution culturelle du capital. Le Capitalisme cybernétique dans la société globale de l'information. Montreal: Écosociété.

Ouellet, Maxime. 2015. Revisiting Marx's Value Theory: Elements of a Critical Theory of Immaterial Labor in Informational Capitalism. The Information Society 31 (1): 20-27.

Papadopoulos, George S. 1994. Education 1960-1990: The OECD Perspective. Paris: OECD.

Postone, Moishe. 1999. Contemporary Historical Transformations: Beyond Postindustrial Theory and Neo-Marxism. Current Perspectives in Social Theory 19: 3-53.

Postone, Moishe. 1993. Time, Labor and Social Domination: A Reinterpretation of Marx's Critical Theory. Cambridge: Cambridge University Press.

Prado, Plinio. 2009. Le principe université. Paris: Éditions Lignes.

Readings, Bill. 1997. The University in Ruins. Cambridge: Harvard University Press.

Robins, Kevin and Frank Webster, eds. 2003. The Virtual University? Knowledge, Markets, and Management. Oxford: Oxford University Press.

Rupert, Mark. 2000. Ideologies of Globalization: Contending Visions of a New World Order. London: Routledge.

Salmi, Jamil. 2009. Le défi d'établir des universités de rang mondial. Washington: World Bank. Accessed July 28, 2017. http://siteresources.worldbank.org/EDUCATION/Resources/2782001099079877269/547664-1099079956815/547670-1237305262556/WorldClass Universities French.pdf

Schwab, Klaus. 2016. The Fourth Industrial Revolution. Geneva: World Economic Forum.

Singer, Natasha. 2017. How Google Took Over the Classroom. New York Times, May 13. Accessed 13 January 2018. https://www.nytimes.com/2017/05/13/technology/googleeducation-chromebooks-schools.html

Sklair, Leslie. 1991. Sociology of the Global System. Hertfordshire: Harvester Wheatsheaf.

Slaughter, Sheila and Larry L. Leslie. 1999. Academic Capitalism: Politics, Policies, and the Entrepreneurial University. Baltimore: Johns Hopkins University Press. 
Smith, Aaron and Janna Anderson. 2014. Al, Robotics, and the Future of Jobs. Pew Research Center, August 6. Accessed 13 January 2018. http://www.pewinternet.org/2014/08/06/future-of-jobs

Smythe, Dallas W. 1977. Communications: Blindspot of Western Marxism. Canadian Journal of Political and Social Theory 1 (3): 1-28.

Stiegler, Bernard. 2012. États de choc. Bêtise et savoir au XXle siècle. Paris: Mille et une nuits.

The Economist. 2011. Higher Education: The Latest Bubble? The Economist, April 13. Accessed 13 January 2018. http://www.economist.com/blogs/schumpeter/2011/04/higher education

UK Government. 2013. Press Release: New Push to Grow UK's £17.5 Billion Education Exports Industry. Accessed July 28, 2017. https://www.gov.uk/government/news/new-pushto-grow-uks-175-billion-education-exports-industry

Vercellone, Carlos. 2004. Division internationale du travail, propriété intellectuelle et développement à l'heure du capitalisme cognitive. Géographie Économie Société 6 (4): 359381.

World Economic Forum. 2016. The Future of Jobs: Employment, Skills and Workforce Strategy for the Fourth Industrial Revolution. Geneva: World Economic Forum. Accessed July 28, 2017. http://www3. weforum.org/docs/WEF Future of Jobs.pdf

Zeller, Christian. 2008. From the Gene to the Globe: Extracting Rents Based on Intellectual Property. Review of International Political Economy 15 (1): 86-115.

Zhang, Jie. 2014. Developing Excellence: Chinese University Reform in Three Steps. Nature, October 15. Accessed 13 January 2018. www.nature.com/news/developing-excellencechinese-university-reform-in-three-steps-1.16128

\section{About the Authors}

\section{Maxime Ouellet}

Maxime Ouellet is a professor at the Media School of the Université du Québec à Montréal (UQAM). He co-wrote and directed, with Éric Martin, University Inc. Myths About Rising Tuition Fees and the Knowledge Economy (Lux 2011) and The Tyranny of Value. Debates for the Renewal of Critical Theory (Ecosociété 2014). His most recent essay is entitled The Cultural Revolution of Capital. Cybernetic Capitalism in the Global Information Society (Ecosociété 2016).

\section{Éric Martin}

Éric Martin is a philosophy professor in Cégep Édouard-Montpetit (Longueuil, QC). He cowrote and directed, with Maxime Ouellet, University Inc. Myths About Rising Tuition Fees and the Knowledge Economy (Lux 2011) and The Tyranny of Value. Debates for the Renewal of Critical Theory (Ecosociété 2014). 


\title{
On the Alienation of Academic Labour and the Possibilities for Mass Intellectuality
}

\author{
Richard Hall
}

De Montfort University, Leicester, UK, rhall1@dmu.ac.uk, http://richard-hall.org

\begin{abstract}
As one response to the secular crisis of capitalism, higher education is being proletarianised. Its academics and students, increasingly encumbered by precarious employment, debt, and new levels of performance management, are shorn of autonomy beyond the sale of their labour-power. Incrementally, the labour of those academics and students is subsumed and re-engineered for value production, and is prey to the twin processes of financialisation and marketisation. At the core of understanding the impact of these processes and their relationships to the reproduction of higher education is the alienated labour of the academic. The article examines the role of alienated labour in academic work in its relationship to the proletarianisation of the University, and relates this to feelings of hopelessness, in order to ask what might be done differently. The argument centres on the role of mass intellectuality, or socially-useful knowledge and knowing, as a potential moment for overcoming alienated labour.
\end{abstract}

Keywords: Academic Labour, Alienation, Higher Education, Mass Intellectuality, Proletarianisation

\section{Introduction: Academic Labour in Crisis}

Academic labour is globally being restructured in response to the secular crisis of capitalism (Bellamy Foster and Yates 2014; Hall 2015). Such restructuring emerges through a desperate need to expand the generation of surplus-value, which has catalysed the subsumption of previously socialised goods like healthcare, welfare and education under the dictates of financialisation and marketisation (Davies 2014). In spite of this subsumption, capital has been unable to reinstate stable forms of accumulation (Jappe 2014). As a result, this inability questions both the subordination of policy to economic determinism and the legitimacy of neoliberal regimes of governance.

The subsumption of higher education (HE) under the structuring logic of value has highlighted the weakening of autonomy for the academic labourer beyond the temporary amelioration of her labour relations with those who direct the University. This applies across the terrain of HE in terms of teaching, learning, research and administration, for both academics and students. Moreover, it plays out through a policy narrative with two functions. First, it fetishises specific capabilities related to the generation of human capital, and in particular entrepreneurialism and employability. Second, it increases the proletarianisation of academic labour through organisational development and technological rationalisation (Dyer-Witheford 2015, 19-38). One result is the internalisation of performativity and an increasing number of published narratives of academic and student ill-health or of their quitting the academy, and in particular of a rise in anxiety (Ball 2015; Hall and Bowles 2016).

These narratives signal a rupture in the academic psyche, as the processes through which the academic labour of staff and students is subsumed and reengineered are increasingly defined by "the social tyranny of exchange-value" 
(Wendling 2009, 52). Such ruptures are an outcome of the alienation of the academic labourer from: first, her labour-power, which is made precarious as it is sold in the market; second, the products of her labour, which are financialised and marketised for their exchange-value rather than their social utility; third, herself as she becomes a self-exploiting entrepreneur; and fourth, her humanity as a species-being, reinforced through global competition (Marx and Engels 1998/1846).

In understanding and then addressing the ways in which academics are reproduced as competing human capitals, it is necessary to reconnect the academic project to its genesis in alienated labour. In order to understand how processes of financialisation and marketisation are affecting the academic ego, by reshaping scholarship and research as knowledge transfer, through spillover activity and impact, and in redefining teaching as excellence (Newfield 2016), it is necessary to reconnect the categorical labour of academics to the site of its alienation. As Clarke $(1991,52)$ notes:

In alienated labour a social relation between people appears in the form of the subordination of a person to a thing. This social relation is the relation of private property, in which the capitalist appropriates the means of production as his private property, so permitting him to subordinate the labourer to his own will.

A discussion of the relationship between alienated labour, competition and the production/circulation/consumption of academic products is central to how we might reimagine the purposes of academic work. For Clarke (1991), this discussion pivots around alienated labour as the key to understanding the ways in which capitalist society mediates our activity, with a focus on their overcoming.

In revealing alienated labour as a site of the proletarianisation of academic labour, it is possible to ask: against this structural, secular alienation, might academic labour be re-evaluated for its social use? Against these stresses, is it possible to reclaim the university as site of struggle for both academics and students? This paper situates such a re-evaluation or reclamation against the idea of "mass intellectuality," or the possibility that academics and students might imagine that their skills, practices and knowledges can be shared and put to another use, in common and in co-operation (Hall 2014). This focuses on recovering the subjectivity of the student or academic as part of a social struggle focused upon pre-figurative and co-operative alternatives (Marx 1866; 1875; Marx and Engels 1998/1846). By engaging with concrete examples of how academics and students are working to overturn the conditions of their alienated labour, this responds to Clarke's $(1991,255)$ call "to resume the project which Marx initiated of linking an emancipatory social theory to an emancipatory social practice." Such a project situates the exploitation of academic labour against the wider exploitation of paid and unpaid labour in the social factory. Not only must the academic labourer overcome her own competition with other academics to reduce her exploitation, but she must situate this cognitively and emotionally against the abolition of wage-labour more generally.

\section{The Proletarianisation of Higher Education}

Dyer-Witheford (2015) argues that capitalism can be represented as an unstable, self-expanding and dynamic force field, or vortex. For Dyer-Witheford, one of the 
drivers of the energy flows inside the vortex is the ongoing proletarianisation of global labour, driven in-part cybernetically through the integration of humans and digital technologies. This integration occurs in the interstices between consumption, production and financialisation. Such a cybernetic re-imagination of work situates the labourer as part of a global machine of value production, whilst decomposing the technical composition of that labour.

$\mathrm{HE}$ is also caught up in these cyclonic processes of production, consumption and financialisation. In England this has been amplified through the rapid increase in student fees, the implementation of metrics like the National Student Survey and Longitudinal Education Outcomes, and institutional audits like the Research Excellence Framework and the Teaching Excellence Framework. Sitting inside a policy framework that includes the HM Treasury Productivity Plan (2015), the Small Business, Enterprise and Employability Act (Department for Business, Innovation \& Skills (DBIS) 2015), and the HE and Research Act (Department for Education (DfE) 2017a), these tactics have focused competition for student numbers and research funding at both the institutional and subject-level. As a result, competition instantiated through metrics and league tables dominates academic labour time, such that academics have increasingly little control over the surplus time that the University demands from them.

Competition is the completest expression of the battle of all against all which rules in modern civil society. This battle, a battle for life, for existence, for everything, in case of need a battle of life and death, is fought not between the different classes of society only, but also between the individual members of these classes. Each is in the way of the other, and each seeks to crowd out all who are in his way, and to put himself in their place (Engels 2009/1845, 111).

A driver for the proletarianisation of $\mathrm{HE}$ is the re-engineering of academic work, so that the focus becomes less the concrete labour that produces teaching materials, a journal article, or a report for public engagement. Instead, the focus shifts to the exchange-value that can be extracted from those products through research funding, knowledge transfer, impact or the fees that accompany student retention. Moreover, given the competitive framing for global HE, generating efficiencies in time through technological and organisational innovations enables academic labour to be stripped of its intellectual content. The critical mediation becomes abstract academic labour, measured by the time it takes to produce research outputs and impact, feedback on assessments, and so on. Such innovations are predicated upon the development of the productive power of academic labour and an attrition on its costs. As a result, there is a flow between the following:

- the need for universities to compete and to remain productive through technological and organisational innovation, and new services, such as the implementation of Research Management Systems and learning analytics. This is enabled through a range of corporate partnerships, including those with software retailers, publishers, management consultants and venture capitalists (Carnegie Associates 2013; McKinsey and Company 2017; Pearson 2017); 
- the ability of universities to drive down the labour-time for assessing/teaching/publishing compared to rival institutions, so that it can maintain competitive advantage. Across the United Kingdom, this has led to the implementation of new forms of academic staff workload planning and performance management (Ball 2015);

- rises in casual precarious employment, because by driving down labour costs university senior managers can buy a greater mass of labour power or progressively replace skilled labourers by those who are less skilled. Globally, this affects precariously-employed academics (CASA 2017), precariously-indentured students (CUPE3903 2017), and those professional services staff with poor labour rights (United Voices of the Whole World Union 2017);

- changes in the technical conditions of the process of academic production, which enable new accumulations of academic products to become additional means of production. For instance, the enforcement of lecture capture or of digital learning strategies enables new academic commodities to open-up new markets, especially in the global South (Harris et al. 2012). This was one of the key drivers behind the Massive Open Online Course initiatives (Rizvi et al. 2013), and the rise of the for-profit sector (McMillan Cottom 2017; Newfield 2016);

- the need to sustain and grow surpluses that can be invested in estates and infrastructure projects. In part, this happens as academics set in motion more means of production, for instance by increasing student recruitment, undertaking innovative teaching and research in new markets, and investing more labour in producing digital learning environments (Winn 2015); and

- the drive to centralise and monopolise the production, circulation and accumulation of academic value through comparative national and international league tables, as well as via policy that enables new providers to enter existing HE markets alongside market exit for existing providers (DfE 2017a).

Through these interrelated processes a surplus, precarious population of academics emerges, in the form of postgraduates who teach, adjuncts, casual teachers, associate/full professors, and crucially students, who lack control over the means of production. Following Marx and Engels (2002/1848), we might argue that in order to overcome their surplus, precarious identities, these academic labourers have two options. First, to sell themselves piecemeal, in their teaching, assessment, feedback, research, scholarship, knowledge exchange and impact. Second, to take on increased levels of debt in the hope of generating innovative human capital.

Thus, globally there are: first, reports of adjunct professors who "don't even earn the federal minimum wage" (Saccaro 2014); second, struggles led by postgraduate researcher-led committees that push the University to honour the essential role of teaching assistants in the form of fair pay and labour rights (CUPE3903 2017); third, quitlit reports of academics leaving the profession (Morris 2015); fourth, individuals who witness self-imposed overwork as a form of self-harm; fifth, reports of the suicides of those who are classified as precarious, or for whom status is being removed; and sixth, networks reporting on casualisation (CASA 2017). These realities of proletarianisation form filaments that enable us to trace its roots in alienated labour.

\section{Alienated Labour}

In working towards an alternative to proletarianisation, a critical, negative starting point is to uncover the alienated genesis of academic labour. This, then enables a focus on its overcoming or abolition, as an emancipatory social practice that prefig- 
ures a reimagining of the relationship between higher education and society. In reaching below the surface effects of the reengineering of $\mathrm{HE}$ through competition and value production, we need to address how this appears both as a process of dispossession of time, agency and autonomy for academics and students, and as the appropriation of concrete labour from the standpoint of capital (Marx 1993/1857, 831). A pivot for this analysis is a focus on subjectivity.

Marx's critique of liberalism sought to recover, both in theory and in practice, the constitutive role of human subjectivity behind the immediacy of objective and constraining social relations within which our social identity confronts us in the form of an external thing (Clarke 1991, viii-ix).

Here, the social relationships that define capitalist reality are constructed through historically-specific relations of production, which are themselves rooted in the dispossession and appropriation of everyday, practical and sensuous activity (Marx 2014/1844; Marx and Engels 1998/1846). As Clarke (1991) argues, at the root of Marx's critique of capital was the analysis of how such activity was alienated under capitalism. Here, the apparent starting point is commodity production: "The wealth of societies in which the capitalist mode of production prevails appears as an "immense collection of commodities"; the individual commodity appears as its elementary form" (Marx 2004/1867, 125). In a system of commodity production:

The worker becomes poorer the more wealth he produces and the more his production increases in power and extent. The worker becomes an ever cheaper commodity the more goods he creates. The devaluation of the human world increases in direct relation with the increase in value of the world of things. Labor does not only create goods; it also produces itself and the work as a commodity, and indeed in the same proportion as it produces goods. (Marx 2014/1844, 82)

Moreover, flowing from the sale of labour-power as a commodity, and underpinning alienated labour, is the objectification of labour as it is embodied in the production of physical things, which then come to dominate life:

[...] the object produced by labor, its products, now stands opposed to it as an alien being, as a power independent of the producer. The product of labor is labor which has been embodied in an object and turned into a physical thing; this product is an objectification of labor. The performance of work is at the same time its objectification, the performance of work appears in the sphere of political economy as a vitiation of the worker, objectification is a loss and a servitude to the object, and appropriation is alienation (Marx 2014/1844, 83). 
The labourer's activity is alienated from her precisely because it cannot satisfy her intrinsic needs. At best, it provides means of subsistence. At worst it requires increasing amounts of cognitive dissonance in order both to re-enter the market to resell her labour-power, and to believe that she loves/likes what she does. This takes the form of further self-alienation. Whilst the arguments for entrepreneurialism, employability and the development of human capital inside HE are situated superficially in the development of the individual and her capabilities, as wants that emerge from inside her, they are a function of the desire to expand value production. This is witnessed in the ongoing disciplining of that academic labour-power through performance management and metric-based monitoring (Ball 2015; Pearson 2017). In the process, alienated labour forms the basis of competition, and through it the separation of the individual from her wider communities (Marx, 2014/1844).

From the starting point of alienated labour, private property and thus the domination of capital over the worker emerges. The social necessity of the sale of labourpower for the reproduction both of the labourer and her society, creates an asymmetrical relation of labour to the capital. Thus, the mediation of private property emerges from alienated labour (Marx 2014/1844). For Clarke (1991, 54), it is important to base an analysis of alienation on the relations of production inside capitalism, and to "penetrate beneath the alienated form of labour to see the fundamental contradiction between labour, as the active agent of production, and its alienated (commodity) form which explains both its foundation and the possibility of its overcoming."

Here one of the most important outcomes for academic labour is that a critique of its political economy demonstrates how the focus on status underpins liberal society's preoccupation with private property (including intellectual property and intellectual/social capital). Through such a critique, the foundation of private property (in this case the ownership of academic labour-power) is shown to be social and historical, rather than natural and trans-historical. This opens-up possibilities for challenging the neoliberal obsession with competition, performance management, data-driven risk management, and the generation of abstract human capital. Instead it enables us to challenge the historical, relations of production that characterise academic work, and to generate alternatives. As Clarke argues $(1991,55)$, "If alienated labour is the basis of property, the abolition of property can only take the form of the abolition of alienated labour."

Thus the emancipation of society from private property, etc., from servitude, is expressed in the political form of the emancipation of the workers; not that their emancipation alone is at stake, but because the emancipation of the workers contains universal human emancipation (Marx 2014/1844, 91).

Across the social terrain, the process of overcoming does not depend upon responses to the mediations of performance management. Rather, it depends upon revealing the relationships between alienated labour, the ownership of labour-power and its products, and structures of commodity exchange that are predicated upon the division of labour and private property (Mészáros 2005).

These processes of alienation are amplified because commodity exchange, and in particular the exchange of labour-power, is mediated by money. As Marx noted $(2014 / 1844,175)$, "The need for money [...] the true need produced by the modern economic system, and it is the only need which the latter produces." In part, this ex- 
plains the increasing focus across HE on data and metrics, as a way through which financialisation can be mediated (DfE 2017b; McGettigan 2015). The ability to test research, teaching quality, learning environment, and student outcomes across individual institutions, and then to compare them across national and international educational terrains, becomes a way in which the functions of universities can become locked into the capitalist vortex.

Increasingly money replaces the real object and dominates the subject. In it needs and powers coincide in an abstract way: only those needs are recognized as real needs by an alienated society which can be bought by money i.e. which are within the reach and power of money (Mészáros 2005, 179).

What is hidden or revealed, depending on the level of analysis of financialisation, is the idea/purpose and content of the university as it is structured through academic labour. However, one result is to uncover how the mediations of private property commodity exchange - division of labour infect the university just as they do any other firm, and education as they do any sector of the economy. However, it is only possible to understand the role of financialisation and marketisation, as highly developed forms of private property, through an analysis of the commodification of education, with alienated labour as its point of origin. As Marx argued (2014/1844, 129), "The division of labour is the economic expression of the social character of labour within alienation [...] The division of labour is nothing but the alienated establishment of human activity as real species-activity or the activity of man as a species-being." For Clarke $(1991,59)$, the starting point for a re-imagination of the society is uncovering "the alienated power of social labour."

Such social powers accelerate the processes of proletarianisation noted above, and which are made visible through metrics and performance data, outsourcing and precarious employment, a focus on knowledge transfer and impact, and so on. What is revealed is academic alienation: "Hence the rule of the capitalist over the worker is the rule of things over man, of dead labour over living, of the product over the producer" (Marx 2004/1867, 990). In overcoming such alienation, academics enter into internal and external conflicts. On the one hand, they see their work as contributing to student satisfaction or perceptions of student freedom or autonomy as economic actors possessing new forms of human capital. Here, they also see their own work in terms of its wider societal use, and this is predicated upon abstract ideals of academic freedom and institutional autonomy. On the other hand, such work is increasingly disciplined for exchange-value, and the surplus time given to the production of academic commodities amplifies overwork. The cognitive dissonance between, first, the perceptions of academics that their work has use-value, and, second, the reality that it is subsumed under exchange-value, is increasingly revealed as world-weariness or weltschmerz.

\section{Weltschmerz}

For some academics, weltschmerz, or a world weariness that lies beyond anxiety, anguish or ennui, reflects a deeper sense of hopelessness about the academic project. This is a recognition that the world once hoped for may never be, and that the concrete world now abstracted for value may never embody our deeper humanity. In 
fact, in our abstracted world such hopelessness is connected to a loss of autono$\mathrm{my} /$ freedom that is itself rooted in the inability to escape from capital's domination. Much worse is the fact that the cultural terrain upon which capital works reinforces within us a sense that we are not productive enough, and that this is a sin (Jappe 2014).

As one response, new ideas of good/public and bad/private are projected onto the University (Campaign for the Public University (CPU) n.d., Council for the Defence of British Universities (CDBU) n.d.). However, as the politics of austerity restricts academic autonomy, alternative responses include either incorporating performativity or internalising the loss of what the university might become. Either position risks the development of a new depressive position through which the overwhelming feeling is one of hopelessness. Overcoming such a depressive position requires a different level of grief and mourning to be internalised, so that academics can address their alienation in an authentic manner, and in relation to wider society.

Hopelessness is rooted in the academic's apparent loss of her labour, as it is brought into the service of value. Marx (1844) argued that this is the logic of capitalism as it defenestrates labour, in order that it can accumulate autonomy:

Is then only the semblance of an activity, only a forced activity, imposed upon me only by an external and accidental necessity and not by an internal and determined necessity [...] My labour, therefore, is manifested as the objective, sensuous, perceptible, and indubitable expression of my self-loss and my powerlessness.

Such powerlessness is a reflection of how social or communal spaces, places, identities, and relationships become means of extracting value or hoarding private wealth. Moreover, with the formal subsumption of HE under capitalist social relations, a sense of hopelessness is reinforced as we witness just how far the limits to our alienation from space, society and nature can be pushed. As Berardi $(2009,73)$ argues:

To be recognized in the networked universe one must become compatible with the generative logic of the matrix. What does not belong to a codified domain is not socially recognizable or relevant, although it still exists in the domain of irrelevance, of residuality. It then reacts with rage and despair, in order to violently reassert its existence.

At issue is how agency, or the reassertion of academic autonomy, might be enacted in the face of a technological system that co-opts and reproduces social relationships for the production of value. As academics are torn between ideas of social/public good and individual entrepreneurial activity, cultures of omertà emerge. This is the silence of those in the know, who must co-operate even as they compete, and thereby generate complex inter-relationships rooted in uncertainty and anxiety (Hall and Bowles 2016). In moving beyond this negative critique, the question is how to negate rather than accommodate the basis of domination? Is it possible to imagine a new form of sociability? For Marx $(2014 / 1844,82)$, this reveals the contradictions at the heart of a marketised, economised existence that is predicated on the "increasing 
value of the world of things" at the expense of the "devaluation of the world of men." The question is whether that world can be superseded across the social factory (Federici, 2012), and the role of the university in that overcoming? Here the concept of "mass intellectuality" is a useful heuristic.

\section{The Possibilities for Mass Intellectuality}

The idea of "mass intellectuality" erupts from within the Autonomist Marxist tradition, tracing its lineage to Marx's notion of the "general intellect" (Dyer-Witheford 1999; Virno 1996). Marx $(1993 / 1857,694)$ argued that the dynamics of capitalism meant "the accumulation of knowledge and of skill, of the general productive forces of the social brain, is thus absorbed into capital, as opposed to labour, and hence appears as an attribute of capital, and more specifically of fixed capital [machinery]." The drive to subsume labour formally under the structuring dynamics of value production, underpins organisational development and technological innovation, which themselves emerged through competition over the accumulation of relative surplus value. As a result, the craft and technical skills, capabilities, and knowledge of the social individual are continually absorbed into the things she produces. Therefore, the "general intellect" of society, i.e. its general capacity for natural science fused with philosophy in the broadest sense, is absorbed into capitalised technologies and techniques. Whilst the focus for this is to reduce labour costs and to increase productivity, it corrupts the ability to think critically about the human experience and to solve problems at the level of society (Marx 2014/1844). Instead the focus is on marketised or outsourced solutions to crises.

Starting from an Autonomist position it is important to understand the mechanisms through which the general intellect is co-opted for value production (Virno 2004), so that it might be reclaimed. Thus, the relationship between general intellect and mass intellectuality points beyond the fetishised myth of technology and entrepreneurial activity as the origins of value. Whilst mass intellectuality refers to knowledge and forms of knowing that capital seeks to valorise, it also points towards the immanent (negative) and pre-figurative (positive) potential of new forms of sociability. Mass intellectuality implies a struggle over the proletarianisation of labour, and its emancipatory implications, as the embodiment of the cumulative history of natural science and philosophy. From the standpoint of mass intellectuality, an analysis of the ways in which 'immaterial' production or affective labour and cognitive capital emerge from within structures that are predicated upon alienated labour, enables a critique of the relations of production and a critical understanding of the constant drive to innovate using technology (Manzerolle 2010).

A critique that is based upon alienated labour points towards a focus on alternative educational practices that develop socialised knowledge, or 'mass intellectuality', as a direct, social force of production. This is an attempt to reclaim the concept of living knowledge as useful work, and to reimagine sociability or to define activities that reproduce society against-and-beyond value production. It forms a critique of subjectivity in its relationship to the prevalent mode of (knowledge) production. The potential is for the liberation: first, of those craft and technical skills, capabilities, and knowledge of the social individual that have been absorbed into the things the academic produces; and second, of the academic from the process of production and ultimately from her academic labour and the sale of her academic labour-power. As a form of sociability that it is not restricted by capitalist time, these activities might structure and determine that time for other, autonomous ends (Postone 1996). 
As the University of Utopia (n.d.) argued, a reconsideration of the relationship between general intellect and mass intellectuality, in order to recover the former in the form of the latter, points towards the abolition of alienated labour.

In the society of abundance the university as an institutional form is dissolved, and becomes a social form or knowledge at the level of society (i.e. The General Intellect). It is only on this basis that we can knowingly address the global emergencies with which we are all confronted (University of Utopia n.d.).

In this process new forms of subjectivity emerge that the point beyond labour, and therefore refuse the creation of status divisions inside a reinvigorated capitalist hierarchy. This work is predicated upon co-operation (Marx 1866, 1875; Neary and Winn 2017).

\begin{abstract}
Mass intellectuality is based on our common ability to do, based on our needs and capacities and what needs to be done. What needs to be done raises doing from the level of the individual to the level of society (University of Utopia n.d.).
\end{abstract}

Thus, struggles both inside and outside of the university, to build counter-hegemonic positions rooted in solidarity and sharing, and related to the social and co-operative use of the knowledge, skills and practices that are created by labour, might be analysed in terms of mass intellectuality (Hall and Winn 2017).

One such example is the Social Science Centre (2017) in Lincoln, UK, which can be characterised as a laboratory for co-operative production, consumption and distribution of higher learning. The space is rooted in democratic organising principles (governance) for both the Centre and its activities, and its content (for instance, childcare arrangements, curricula, events). The Centre's pedagogical underpinnings are grounded in democracy, co-operation and solidarity, enriched through a critique of critical pedagogy (Neary $2011 ; 2017$ ). Such a radical re-conceptualisation of the relationship between higher learning and society has also informed the Dismantling the Master's House project (DTMH 2015), which emerged at University College London. This work has emerged deliberately as a collective, student and staff process of questioning the colonial legacies reproduced in the governance, design, delivery and assessment of the curriculum. It questions whether a canonical curriculum, rooted in a specific, abstracted cultural view of the world, can be anything other than 'monstrous'? Indeed, can it enable societies to confront global emergencies that have emerged from the dominance of that very cultural view of the world? The end point for the project is to enact forms of educational repair that are themselves forms of societal repair, because they use the curriculum as a point of departure for delegitimising specific forms of alienation rooted in ongoing historical and material racism (Rhodes Must Fall Oxford 2017).

This work aligns with Neary's (2011, n. pag.) focus on 'the possibility and necessity of progressive social transformation through practical action', with the curriculum forming a space for praxis, rooted in the legitimisation of a counter-narrative. Such counter-narratives have a historical and material basis, which demonstrate the ability 
to organise higher learning inside-and-beyond the Academy with the purpose of solving concrete problems or mitigating/adapting to moments of crisis. For some, this involves forms of resistance and occupation inside the University (After the Fall 2009; Harney and Moten 2013). Elsewhere such reorganisation occurs within formal cooperatives (Mondragon University 2017; Neary and Winn 2017), or in the educational work of social movements (Friends of the Movimento dos Trabalhadores Rurais Sem Terra (MST) 2017; Occupy London 2012; Zibechi 2013). In these more radical spaces, mass intellectuality as a form of reclamation and renewal involves exploring the relationship between affirmative self-actualisation (hooks 1994) and the negative critique of established positions. In the process of reclamation and renewal, a politics of educational autonomy (Dinerstein, 2015) emerges as a form of collective, potential pedagogic energy. For hooks (1994), this is a capacity to live more fully and deeply, and to share in the intellectual and spiritual growth of students and teachers.

These alternative conceptualisations point towards co-operative $\mathrm{HE}$ as offering the possibility to critique the purposes for which the general intellect is commodified rather than made socially-useful. Crucially, relating academic labour to its moment of alienation might act as one critical site in the social struggle to recuperate the general intellect. However, this demands that the products and processes of labour generated at the edges of capitalist work, for instance in education commons, co-operative centres or social movements, are explicitly related to the struggle against alienated labour. The value of mass intellectuality lies in its potential to reveal, critique and overcome alienated labour.

In terms of academia, such an abolition cannot occur in isolation and needs to be connected to the multitudinous refusals of labour inside-and-against the capitalist vortex. Here there must be a refocusing of the academic as a socialised worker, in her relationship to the social factory and to social reproduction. As a result, situating the reproduction of the University and of academic labour against intersectional resistances, in particular the gendered and racialised nature of the relationship between HE and society, forms a moment in the development of co-operative counternarratives (Marx 1866).

In this framing, mass intellectuality offers the potential for the democratic or cooperative reproduction of higher learning at the level of society and rooted in multiple ways of knowing the world. This rejects the mediations of private property, commodity exchange and the division of labour, which are themselves rooted in alienated labour and which define the capitalist university. In considering the possibility for dissolving their labour into the fabric of society, academics might prefigure new forms of productive, scientific and social knowledges, and ways of knowing.

Central to Marx's conception of the overcoming of capitalism is his notion of people's reappropriation of the socially general knowledge and capacities that had been constituted historically as capital. We have seen that, according to Marx, such knowledge and capacities, as capital, dominate people; such re-appropriation, then, entails overcoming the mode of domination characteristic of capitalist society, which ultimately is grounded in labor's historically specific role as a socially mediating activity. Thus, at the core of his vision of a postcapitalist society is the historically generated possibility that people might begin to con- 
trol what they create rather than being controlled by it (Postone 1996, 373).

\section{What Is to Be Done?}

Scott (1987) argues for generating currents of resistance that: are collective and organised; are principled and selfless; have revolutionary consequences; and negate rather than accept the basis of domination. However, the generation of such resistances, across an intersectional set of terrains that acknowledge issues of privilege and apparent powerlessness, require us to recognise how the triptych of private property, commodity exchange and division of labour mask the realities of alienated labour. Given emerging stories of distress across the terrain of HE, which mirror those that emerge in other seams of the social factory, the pandemic of ill-health and overwork cannot be overcome by liberating labour. Instead, resistances that are collective, selfless, revolutionary, and imminent, must be developed pre-figuratively against labour (Amsler 2015; Motta and Cole 2014).

For academics, one way in which such prefigurative activity might be developed is by resisting the compartmentalisation and fragmentation of ourselves so that we are simply seen as academics, teachers, researchers or students, who are impactful. As Marx (2004/1867, 799) notes, this tends to 'mutilate the labourer into a fragment of a man'. Here, mass intellectuality offers a means to re-conceptualise and re-purpose our shared abilities, needs and capacities. One strategy has been to find 'space for casual, adjunct and sessional staff and their allies in Australian higher education to share resources and experiences, and to learn from each other' to support 'long-term casuals in universities whose experience is not reflected in the way that universities plan' (CASA 2017). A second strategy has been to consider where it is possible to say 'no' collectively inside the University, through solidarity actions between students, precariously-employed or untenured academics, professors, and professional services staff. For instance, the 3 cosas campaign (2015) for sick pay, holiday, and pension rights for contract staff at the University of London has now been connected to the International Workers Union of Great Britain. A third strategy has been to focus on immediate, strategic actions like resistance to the Research and Innovation Performance Expectations at Newcastle University (University and College Union at Newcastle 2016). This successfully refused the drive to commodify academic labour time through performance management, workload planning and on-going technological innovation, as means of exploitation. However, these strategies also highlight the importance of working deliberatively against intersectional oppressions, and to carry that deliberative work beyond the University into the fabric of society.

Here the terrain of personal narratives grounded in alienation, which have yet to reveal their root in alienated labour, open-up the possibility that we might discuss an overcoming of academic competition and overwork. O'Dwyer notes how such an abolition or overcoming requires that we start from narratives that highlight how uncertainty generates forms of academic post-traumatic stress.

Twelve years of uncertainty and instability has taken its toll. Multiple moves have taught me never to get too comfortable; to not recycle the packing boxes but instead keep them at the back of the closet. As a result of the unpredictable mix of fellowship successes and rejections, I have internalised the message that I am not good enough. Too many 'down to the wire' moments - in which 
I was forced to wait until just a few weeks before a contract ended to find out if I would have another - have made me question my worth. And so I keep waiting for the other shoe to drop. I keep wondering why they hired me. (O’Dwyer 2016)

However, developing a counter-hegemonic solidarity requires that such narratives are connected to both a critique of academic labour, and the development of social solidarity and the social strike. This situates the exploitation of academic labour against the wider exploitation of paid and unpaid labour in the social factory (Federici 2012). Of course, this must be attempted in association, so that an alternative intellectual, physical and humane existence might offer new forms of sociability that are grounded in autonomy.

A crucial element of this is control over time, and the struggle to make time for practical, material activities, rather than ruthlessly reducing the time available for those activities based on value-for-money and efficiency.

[I]n the communist future, which is not subject to the calculus of value, time must diminish in importance. When we extrapolate Marx's visions of free time, therefore, we must not only envision the lengthening of the disposable hours the worker marks between short stints of productive labor. We must instead imagine a modern life freed from time, or at least modern life freed from time's abstract and alienating dominations (Wendling 2009, 199).

Following Marx (2014/1844), this presupposes that the knowledges, skills and capacities of the academic can be reintegrated across society, rather than controlled by clock-time inside HE. Such repurposed social and communal activity, emerging from a new appreciation of knowledge and knowing, enables a different, concrete set of associations as direct expressions of sociability. This requires praxis in the form of mass intellectuality at the level of society, rather than being corralled as mass education within specific institutions like universities or inside specific, commodified curricula. This is best represented by community-based experiments outside the university (Lazarus 2017; Social Science Centre 2017), or inside social movements (MST 2017; Thorburn 2012). As Marx $(2014 / 1844,115)$ argues, 'The resolution of the theoretical contradictions possible only through practical means, only through the practical energy of man.'

In working to overcome alienated labour, praxis demands sitting with and then teaching hopelessness, in order to develop an authentic negative critique. It is then fundamental to use such a critique prefiguratively to think through the potential for waves of struggle, which demonstrate solidarity between various groups of workers and others across society impacted by austerity. Points of solidarity between HE and the social factory include: the embodied toll that neoliberal restructuring and austerity takes on mental and physical health, including across families; the control of lifeactivity through debt, precarious employment and performance management; the reduction of life to entrepreneurship and employability; the assault on social justice, and labour and human rights; and, the inability of the curriculum to manage issues of crisis concerning poverty, climate change, on-going colonialism and so on. 
Here there is a need to redefine the terms of resistance as cross-sectoral, acting communally or socially, precisely because those communal or social aspects of our identities are being marginalised or reduced, as work and productivity becomes totalising. There is a need to see this work as educational, rooted in a governance framework and organisation that prefigures what we desire. Such forms of resistance question the very nature of our academic labour, and ask how the work of students and academics can dismantle that labour as the starting point of alienation, in order to liberate what is socially-useful (DTMH 2015). This is an active becoming, and demands that academics refuse to be indifferent to their alienated labour, and their selfalienation. Here, our weltschmerz offers a starting-point for uncovering the relationship between proletarianisation and alienation, which in turn offers hope for reimagining higher learning through mass intellectuality. This is our socially-useful, pedagogic task.

\section{References}

After The Fall. 2010. Communiqués from Occupied California. Accessed July 29, 2017. http://libcom.org/files/afterthefall communiques.pdf

Amsler, Sarah. 2015. The Education of Radical Democracy. London: Routledge.

Ball, Stephen. 2015. Accounting for a Sociological Life: Influences and Experiences on the Road from Welfarism to Neoliberalism. British Journal of Sociology of Education 36 (6): 817-831.

Bellamy Foster, John and Michael Yates. 2014. Piketty and the Crisis of Neoclassical Economics. Monthly Review. Accessed July 29, 2017. http://monthlyreview.org/2014/11/01/piketty-and-the-crisis-of-neoclassical-economics

Berardi, Franco. 2009. The Soul at Work: From Alienation to Autonomy. Los Angeles: Semiotext(e).

Carnegie Associates. 2014. MOOCs: Opportunities for Their Use in Compulsory-Age Education. DfE Research Report. Accessed July 29, 2017. https://www.gov.uk/government/uploads/system/uploads/attachment data/file/315591/DfE RR355 - Opportunities for MOOCs in schools FINAL.pdf

Clarke, Simon. 1991. Marx, Marginalism and Modern Sociology: From Adam Smith to Max Weber. London: Palgrave.

CASA. 2017. A Home Online for Casual, Adjunct, Sessional Staff and Their Allies in Australian Higher Education. Accessed July 29, 2017. http://actualcasuals.wordpress.com

CDBU. 2017. Council for the Defence of British Universities. Accessed July 29, 2017. http://cdbu.org.uk

CPU. 2017. Campaign for the Public University. Accessed July 29, 2017. http://publicuniversity.org.uk

CUPE3903. 2017. Representing, Organizing and Activating the Contract Faculty, Teaching Assistants, Graduate Assistants, and Research Assistants @ York University, Toronto, Canada. Accessed July 29, 2017. http://3903.cupe.ca

Davies, Will. 2014. The Limits of Neoliberalism: Authority, Sovereignty and the Logic of Competition. London: SAGE.

DBIS. 2015. The Small Business, Enterprise and Employment Act. London: HM Stationery Office. Accessed July 29, 2017. http://www.legislation.gov.uk/ukpga/2015/26/pdfs/ukpga 20150026 en.pdf

DfE. 2017a. The Higher Education and Research Act. London: HM Stationery Office. Accessed July 29, 2017. http://www.legislation.gov.uk/ukpga/2017/29/pdfs/ukpga 20170029 en.pdf

DfE. 2017b. Graduate Outcomes for All Subjects by University. London: DfE. Accessed July 29, 2017. https://www.gov.uk/government/statistics/graduate-outcomes-for-all-subjectsby-university 
Dinerstein, Ana. 2015. The Politics of Autonomy in Latin America: The Art of Organising Hope. London: Palgrave Macmillan.

DTMH. 2015. Dismantling the Master's House. Accessed July 29, 2017. http://www.dtmh.ucl.ac.uk

Dyer-Witheford, Nick. 2015. Cyber-Proletariat: Global Labour in the Digital Vortex. London: Pluto Press.

Dyer-Witheford, Nick. 1999. Cyber-Marx: Cycles and Circuits of Struggle in High Technology Capitalism. Urbana: University of Illinois Press.

Engels, Friedrich. 2009/1845. The Condition of the Working Class in England. London: Penguin.

Federici, Sylvia. 2012. Revolution at Point Zero: Housework, Reproduction and Feminist Struggle. Oakland: PM Press.

Hall, Richard. 2015. The University and the Secular Crisis. Open Library of Humanities. Accessed July 29, 2017. http://doi.org/10.16995/olh.15

Hall, Richard. 2014. On the Abolition of Academic Labour: The Relationship Between Intellectual Workers and Mass Intellectuality. tripleC: Communication, Capitalism \& Critique 12 (2): 822-837. Accessed July 29, 2017. http://triple-C.at/index.php/tripleC/article/view/597

Hall, Richard and Kate Bowles. 2016. Re-engineering Higher Education: The Subsumption of Academic Labour and the Exploitation of Anxiety. Workplace: A Journal for Academic Labor 28: 30-47. Accessed July 29, 2017. http://bit.ly/2dQMx8X

Hall, Richard and Joss Winn, eds. 2017. Mass Intellectuality and Democratic Leadership in Higher Education. London: Bloomsbury Academic.

Harney, Stefano and Fred Moten. 2013. The Undercommons: Fugitive Planning \& Black Study. Brooklyn: Minor Compositions.

Harris, Karen, Andrew Schwedel and Austin Kim. 2012. A World Awash in Money. Accessed July 29, 2017. http://www.bain.com/publications/articles/a-world-awash-in-money.aspx

HM Treasury. 2015. Fixing the Foundations: Creating a More Prosperous Nation. London: HM Treasury. Accessed July 29, 2017.

https://www.gov.uk/government/uploads/system/uploads/attachment data/file/443898/Pro ductivity Plan web.pdf

hooks, bell. 1994. Teaching to Transgress: Education as the Practice of Freedom. London: Routledge.

Jappe, Anselm. 2014. Towards a History of the Critique of Value. Capitalism, Nature, Socialism 25 (2): 25-37.

Lazarus, Joel. 2017. Reconciling mass Intellectuality and higher Education: Lessons from the PPE Experience. In Mass Intellectuality and Democratic Leadership in Higher Education, edited by Richard Hall and Joss Winn, 141-55. London: Bloomsbury Academic.

Manzerolle, Vincent. 2010. The Virtual Debt Factory: Towards an Analysis of Debt and Abstraction in the American Credit Crisis. tripleC 10 (2): 221-36. Accessed July 29, 2017. http://www.triple-c.at/index.php/tripleC/article/view/149

Marx, Karl. 2014/1844. Economic and Philosophical Manuscripts. London: Bloomsbury.

Marx, Karl. 2004/1867. Capital, Volume 1: A Critique of Political Economy. London: Penguin.

Marx, Karl. 1993/1857. Grundrisse: Outline of the Critique of Political Economy. London: Penguin.

Marx, Karl. 1875. Critique of the Gotha Program. Accessed July 29, 2017. https://www.marxists.org/archive/marx/works/1875/gotha

Marx, Karl. 1866. Instructions for the Delegates of the Provisional General Council: The Different Questions. Accessed July 29, 2017. http://www.marxists.org/archive/marx/works/1866/08/instructions.htm

Marx, Karl. 1844. Comments on James Mill. Accessed July 29, 2017. http://www.marxists.org/archive/marx/works/1844/james-mill

Marx, Karl and Friedrich Engels. 2002/1848. The Communist Manifesto. London: Penguin. 
Marx, Karl and Friedrich Engels. 1998/1846. The German Ideology: Including Theses on Feuerbach and Introduction to the Critique of Political Economy. New York: Prometheus.

McGettigan, Andrew. 2015. The Treasury View of HE: Variable Human Capital Investment. Political Economy Research Centre Papers Series 6. Accessed July 29, 2017. http://www.perc.org.uk/perc/wp-content/uploads/2015/04/PERC-6-McGettigan-and-HEand-Human-Capital-FINAL-1.pdf

McKinsey and Company. 2017. Education. Accessed July 29, 2017. http://mckinsey.com/industries/social-sector/how-we-help-clients/education

McMillan Cottom, Tressie. 2016. Lower Ed: The Troubling Rise of For-Profit Colleges in the New Economy. New York: The New Press.

Mészáros, István. 2005. Marx's Theory of Alienation. London: Merlin Press.

Mondragon University. 2017. What is Mondragon University? Accessed July 29, 2017. http://www.mondragon.edu/en/about-us/what-is-mu

Morris, Amanda. 2015. The Rise of 'Quit Lit': What It Is and Why It Matters [Opinion]. Noodle.com. Accessed July 29, 2017. http://bit.ly/2dAimp9

Motta, Sara and Mike Cole. 2014. Constructing $21^{\text {st }}$ Century Socialism in Latin America: The Role of Radical Education. New York: Palgrave Macmillan.

MST. 2017. What is the MST? Accessed July 29, 2017. http://www.mstbrazil.org/content/what-mst

Neary, Mike. 2017. Pedagogy of Hate. Policy Futures in Education. Accessed July 29, 2017. https://doi.org/10.1177/1478210317705742

Neary, Mike. 2011. Student as Producer: A Pedagogy for the Avant-Garde; Or, How Do Revolutionary Teachers Teach? Learning Exchange 1 (1). Accessed July 29, 2017. http://eprints.lincoln.ac.uk/4186/

Neary, Mike and Joss Winn. 2017. There is an Alternative: A Report on an Action Research Project to Develop a Framework for Co-operative Higher Education. Learning and Teaching: The International Journal of Higher Education in the Social Sciences 10 (1): 87-101.

Newfield, Christopher. 2016. The Great Mistake: How We Wrecked Public Universities and How We Can Fix Them. Baltimore: Johns Hopkins University Press.

Occupy London. 2012. Tent City University. Accessed July 29, 2017. http://occupylondon.org.uk/category/working-groups/tent-city-university

O'Dwyer, Siobhan. 2016. This (Un)certain Life. Accessed July 29, 2017. https://researchthatcares/2016/03/13/this-uncertain-life

Pearson. 2017. Efficacy and Research. Accessed July 29, 2017. http://www.pearson.com/corporate/efficacy-and-research.html

Postone, Moishe. 1996. Time, Labor and Social Domination: A Reinterpretation of Marx's Critical Theory. Cambridge: Cambridge University Press.

Rhodes Must Fall Oxford. 2017. Accessed July 29, 2017. https://rmfoxford.wordpress.com

Rizvi, Saad, Katelyn Donnelly and Michael Barber. 2013. An Avalanche is Coming: Higher Education and the Revolution Ahead. Institute for Public Policy Research. Accessed July 29, 2017. http://www.ippr.org/publications/an-avalanche-is-coming-higher-education-andthe-revolution-ahead

Saccaro, Matt. 2014. Professors on Food Stamps: The Shocking True Story of Academic in 2014. Salon. Accessed July 29, 2017.

http://www.salon.com/2014/09/21/professors on food stamps the shocking true story of academia in 2014/

Scott, James. 1987. Weapons of the Weak: Everyday Forms of Peasant Resistance. Yale: Yale University Press.

The Social Science Centre. 2017. Accessed July 29, 2017. http://socialsciencecentre.org.uk

Thorburn, Elise. 2012. Actually Existing Autonomy and the Brave New World of Higher Education. Occupied Studies. Accessed July 29, 2017. http://bit.ly/xzcPRO

Universities and Colleges Union at Newcastle. 2016. A Local Victory of National Significance: Branch Secretary's Report, 2015-2016. Accessed July 29, 2017. 
http://newcastle.web.ucu.org.uk/a-local-victory-of-national-significance-branch-secretarysreport-2015-6

The University of Utopia. 2014. Anti-Curricula: A Course of Action. Accessed July 29, 2017. http://www.universityofutopia.org/sharing

United Voices of the Whole World Union. 2017. Justice for LSE Cleaners. Accessed July 29, 2017. https://www.uvwunion.org.uk/uvwnews?category=Justice+for+LSE+Cleaners

Virno, Paolo. 2004. A Grammar of the Multitude. Los Angeles: Semiotext(e).

Virno, Paolo. 1996. Virtuosity and Revolution. In Radical Thought in Italy: A Potential Politics, edited by Michael Hardt and Paolo Virno, 190-201. Minneapolis: University of Minnesota Press.

Wendling, Amy. 2009. Karl Marx on Technology and Alienation. London: Palgrave Macmillan.

Winn, Joss. 2015. Writing About Academic Labour. Workplace: A Journal for Academic Labor 25: 1-15. Accessed July 29, 2017. http://ices.library.ubc.ca/index.php/workplace/article/view/185095.

Zibechi, Raúl. 2013. Autonomous Zapatista Education: The Little Schools of Below. Accessed July 29, 2017. http://upsidedownworld.org/archives/mexico/autonomous-zapatistaeducation-the-little-schools-of-below

3 cosas campaign. 2014. Accessed July 29, 2017. http://3cosascampaign.wordpress.com

\section{About the Author}

Richard Hall

Richard Hall is Professor of Education and Technology at De Montfort University, Leicester, UK. At DMU he is Co-Director of the Institute for Education Futures (http://ief.our.dmu.ac.uk). Richard is a UK National Teaching Fellow, a co-operator at the Social Science Centre in Lincoln, UK, and a Trustee of the Open Library of Humanities. He writes about life in higher education at: http://richard-hall.org. 


\title{
Professing Contradictions: Knowledge Work and the Neolib- eral Condition of Academic Workers
}

\author{
Marco Briziarelli* and Joseph L. Flores** \\ *University of New Mexico, Albuquerque, US, mbriziarelli@unm.edu \\ **University of New Mexico, Albuquerque, US, jlflores2@unm.edu
}

\begin{abstract}
In this paper, we will provide an interpretation of the condition of academic labour, which is understood as a particular kind of knowledge work and labour. Our objective is to explore the contradictory condition of academics in terms of class position, production of value and subjectivity, showing both its idiosyncrasies as well as its alignment with the broader experience of working in current post-Fordist capitalism. First, paying particular attention to the US media and communication departments that develop critical cultural scholarship, we reflect on the unresolved impasse deriving from the distinction of mental and manual labour. Second, we describe this profession as being characterized by a contradictory class location and a valorization that relies on a continuous negotiation for better exchange rate between intellectual and financial capital. Third, we consider how such a context subjectively translates in an ever-resolved condition of 'employability,' which comprises vocational aspects and the necessity dictated by the hope to reach stability and recognition.
\end{abstract}

Keywords: Knowledge Work, Knowledge Labour, Mental and Manual Labour, Gramsci, Bourdieu, Terranova, Free Labour, Employability

Throughout recent history, intellectuals integrated in academia have consistently inhabited a liminal position in the social organisation, which has uncomfortably placed them in between intellectual and manual labour, and in a contradictory class position between subalternity and dominance. Scholars of humanities and social sciences, especially, are rarely perceived as workers contributing to the material production in a given society.

In the specific cultural and political context considered in this paper, i.e. US humanities departments, scholars are caught in the cross fire between the neo-liberal restructuration of higher education (Radder 2010) and Trump's overt populist antiintellectualism. While the two tendencies are clearly connected, they exert pressure at different levels: on the one hand, the neoliberal model of higher education pushes to increasingly commodify and privatize universities by asserting economic efficiency, high productivity, anti-unionism, the extraction of value from both students and instructors, and pursue a 'divide and conquer' strategy against any kind of collective resistance by the powerful means of meritocratic ideology; on the other, Trumpism professes the value of personal authenticity, genuine vernacularity and healthy American pragmatism, trading 'book smartness' and abstract knowledge for 'street smartness' and immediate concrete results. As a consequence, academic labour progressively enters a condition of precarity and lack of recognition.

In relation to such context, in this paper we will provide an interpretation of the condition of the academic profession, which is understood as a particular kind of knowledge work and labour. Explicitly, we consider the diverse venue and institutional frameworks that higher education has historically taken in different regions while 
being mindful of the limits in the generalization of our analysis. In a country that has consistently been at the forefront of the neoliberalization process, tenured positions in US research institutions appear to the populist right-wing as the exemplification of status quo, a remanence of 'pre-modern' privilege unfairly granted to 'progressive' intellectuals.

Thus, in relation to such depiction, our objective is to explore its contradictory condition in terms of class position, production of value and subjectivity, by showing both its idiosyncrasies as well as its alignment with the broader experience of working in current post-Fordist capitalism. First, by paying particular attention to the media and communication departments that develop critical cultural scholarship, we reflect on the unresolved impasse deriving from the distinction of mental and manual labour. Second, we contextualize this profession as knowledge work and labour, being characterized by a contradictory class location and a valorization that relies on a continuous negotiation for better exchange rate between intellectual and financial capital (Bourdieu 1988).

Academic subjectivities are shaped by a variety of tendencies conflicting with each other: living in debt for many years; a condition of existential and material precarity while aspiring to a privileged job security, i.e. tenure; experiencing authorship both as a potential rejection of modern alienation and losing control of their own production by giving up intellectual property rights; and finally attending in the classroom the perplexing liberalization of the student/instructor relationship. We consider such a subjective condition to be synthetized in the condition of 'employability,' which comprises vocational aspects and the necessity dictated by the hope to reach stability and recognition.

\section{The Need to Materialize and Historicize Intellectual Labour}

Said (1993) synthetizes quite eloquently the contradictory position in which intellectuals in the university seem to find themselves: having access to a superior understanding of reality, but also being either out of touch with reality or wrongly invested in it. In this paper, we claim that part of such representation derives from their location in the productive organisation of Western societies. In fact, as suggested elsewhere (Briziarelli 2013), defining the activity of academicians in terms of academic labour that produces value though socially necessary labour time (Marx 1990) does not only serve to push against idealist conceptualizations of the 'intellectual,' but also helps explain the contradictions that inhabit and significantly constrain such fields of action.

Part of the issue is the false distinction between mental and manual labour, which, based on Cartesian ontology, traditionally relegates the former at the margin of material social production. As Gramsci says in a well-known passage of Quaderni (1975):

All men are intellectuals, one could therefore say: but not all men have in society the function of intellectuals [...] When one distinguishes between intellectuals and nonintellectuals, one is referring in reality only to the immediate social function of the professional category of the intellectuals, that is, one has in mind the direction in which their specific professional activity is weighted, whether towards intellectual elaboration or towards muscularnervous effort. This means that, although one can speak of intellectuals, one cannot speak of non-intellectuals, be- 
cause non-intellectuals do not exist. But even the relationship between efforts of intellectual-cerebral elaboration and muscular-nervous effort is not always the same, so that there are varying degrees of specific intellectual activity. There is no human activity from which every form of intellectual participation can be excluded: homo faber cannot be separated from homo sapiens. Each man, finally, outside his professional activity, carries on some form of intellectual activity, that is, he is a "philosopher", an artist, a man of taste, he participates in a particular conception of the world, has a conscious line of moral conduct, and therefore contributes to sustain a conception of the world or to modify it, that is, to bring into being new modes of thought.

Gramsci's materialist reflection enters into conversation with debates that have consistently concerned traditional epistemology and the equally traditional distinction between 'dispositional-knowledge-that' (episteme) on the one hand, and 'propositional knowledge-how' (technê) on the other. Accordingly, for instance, by the statement "she knows how to ride a bicycle" we could alternatively mean that she only knows the theory of riding a bicycle or she only practices riding, but not, for instance, the physics behind it.

Conversely, the implication of the unity of homo faber and homo sapiens is for Gramsci twofold. On the one hand, he intends to go beyond the distinction between intellectual and practical knowledge by the means of a materialist anthropology. Thus, in the same way as Marx (1990) compares the worst architect with the spider and the bee, Gramsci maintains that the creation and interpretation of meaning consistently happen in social practical situations in which thinking and acting become an indissoluble unity. On the other, still linked to the historicity of unity of theory and action, such a materialist perspective suggests that, even when performing as detached agents and omniscient observers of the world, i.e. as "traditional intellectuals" (Gramsci 1975, 474), academic's agency is always historically and socially situated, actively participating in the process of production and reproduction of a given social order.

In our view, Gramsci's culturally materialist reflections on intellectuals help us to understand the ambiguity that historically concerned critical scholarship in humanities departments of US academia. In this sense, we identify two main aspects to be considered. First of all, we claim that the dominance of a selective tradition of cultural studies that has abandoned the "doubleness of culture [... as both] material reality and lived experience" (Eagleton 2000,36) moved the object of study and the agency of scholars to an idealist terrain. That is because all relevant knowledge becomes 'culture,' and culture in turn becomes the ideological product of articulation (Hall 1992) of a discursive hegemony thus tied to a reductive view of power as a symbolic category. Consequently, in the university programs in which critical and cultural studies have shaped scholarship, the work of academicians has been more frequently associated to a deconstructive cultural critique activity rather than productive material labour.

Especially in our field of communication and media studies, talking about academic production of value in the context of informational capitalism seems almost paradoxical because as Discenna (2011) notes, the field of communication has historically failed to consider labour (especially, academic labour) as a possible research per- 
spective. For Discenna, centring academic labour means "calling for a reorientation of the field to the material conditions of our own work," which forces the field of communication to correct the "neglect of labor issues" while conducting research (1844).

In respect to that, willing to push against such tendencies, our intervention intends to highlight the fetishized aspects of the material production of our labour. We intend to correct what for Fuchs (2016) are the competing fetishisms of labourism and culturalism, where the former dissolves culture into a manufactured reflective production, and the latter dissolves economy into signifying symbols. As Denning (2004) notes "work and culture seem to be opposite in a number of ways," suggesting researchers need to understand that, "culture is seen as the equivalent of leisure, not labor; the symbolic, not the material" (93).

The second important aspect to take into account in order to understand academic labour has to do with the fact that current conditions of production in many Western countries have historically emphasized the valorization of knowledge production, circulation and reproduction. Thus, in order to provide a general account of the political economy of academic labour, we place it in the context of knowledge work and informational capitalism.

\subsection{Knowledge Work as the Political Economy of Academic Labour}

The current capitalist context of many Western societies has placed communication and information technologies at the centre of the capitalist production, as platforms for production of goods and employment of labour linked to knowledge production and circulation. Not by accident, the vision of a media driven capitalism as it was foreseen by Horkheimer and Adorno with their 'culture industry' thesis (1974) seems to be confirmed by current dictions such as 'informational capitalism', 'cognitive capitalism,' 'digital capitalism' (Fuchs 2009). As a result, academic labourers, then, are increasingly subject to a post-Fordist, intellectual capitalism that involves the integration of "science, information, linguistic communication, and knowledge in general" (Virno 1996, 267).

The informational disposition of current capitalism develops as the result of the intersection of several factors such as the development of a new mode of production centred around information and communication technology, the emergence of the media using internet platforms, and the overall transition to the logic of production that we could define as industrial - regulated from above by control, managers and a legal framework of contract - to a post-industrial one based on self-regulation, selfenactment and developed communicational and relational capabilities of the worker (Beck 2000).

Not accidentally, the re-organisation of an ample sector of production around ICTs also created a category of skilled workers that manage different levels of knowledge and intellectual activity. Specifically, Bratich (2008) notes that "labor has increasingly become intellectualized in three ways: a) the contents produced (information, symbols, affect); b) the technologization and industrial forms (computer skills now required to run many factory lines) and; c) the collaborative informational networks implemented to produce new and old commodities" (30). In this context, "the brain and its bodily mediations are enabled to engage in organic practices of economic production, surplus-value generation, coproduction, communicative circulation, and productive consumption by new media" (Fuchs 2010, 191).

Appropriately, when considering academic knowledge, it is important to note that, according to a Marxian perspective "any laboring activity, material or immaterial, is productive labor so long as it produces surplus value for a capitalist" (Koloğlugil 
$2015,127)$. Hence, "exploitation today is also the exploitation of human creative capacities" and the "expropriation of the common" (Fuchs 2010, 188). Along the same line, according to Hardt and Negri (2004), "relationships, communication, and knowledge are goods that are produced in common, but are appropriated by capital for economic ends" (150). Noticeably, skills that are acquired from the general intellect (Marx 1973), and skills that are acquired through work specifically in academic knowledge, are centred as the "power of knowledge, objectified" (706). In this way, academic knowledge exists as surplus value in which human intellectual and cognitive abilities are positioned as skills optimal for survival (Koloğlugil 2015).

However, despite its increasing weight in the overall social organisation of production of value, academic knowledge work remains scarcely visible because of its alleged 'immateriality' (Lazzarato 1996), but also, as we will discuss in the next section, by an ambiguous class location.

\subsection{A Contradictory Class Location}

Academic labourers make up a part of the multitude in the way Fuchs understands it (2010) as an inter-class precariat "who produces material or knowledge goods and services directly or indirectly for capital and are deprived and expropriated of resources by capital" (186). By defining class this way, academic knowledge becomes an increasingly permeated layer of exploitation in the academy. As defined by Fuchs, knowledge workers "are wage labourers and produce knowledge goods and services in wage relationships or self-employed labour relations" (187). Perpetually precarious, academic knowledge workers are often in constant flux in class positions, and under the pressure of continued intellectualization (Bratich 2008). As Gorz (2010) notes, capital in its post-industrial age goes beyond coercing all time outside the factory to consuming all mental, social, and cultural factories that exist outside the working hours.

The absence of class definition may be in part caused by the ambiguous class location of academicians. In this sense, a recurrent problem in Marxist class analysis consists of making sense of intermediate class positions that resist localization within the primordial confrontation between 'capitalist' and working class. That is indeed the case of intellectuals integrated in the academic system, who, applying here Wright's taxonomy (1997), occupy a "contradictory class location" (23). In this sense, within the political economy of higher education, like managers in Wright's analysis, academicians hold contradictory interests as a class, similar to the managerial class, as both employed and exerting control. In fact, while they are exploited as employed labourers, especially in the case of graduate students and non-tenure track instructors, yet their highly specialized formation and twofold authority - i.e. status and social visibility as well as recognition and authority in the sense of producer of content also controls graduate and undergraduate students' unpaid labour; in other words, the uncompensated production of knowledge such as voluntary participation in studies, and credited and un-credited work towards the writing of articles. Moreover, their position is also ambiguous as salaried semi-autonomous professionals who do not completely own all the means of production but still exercise extensive control over such production as in teaching and the writing process. According to such a view, academicians move within those interstitial positions, between prerogative and coercion, privileged and oppressive power, another layer of the increasingly growing cultural and 'creative industries' (Hesmondhalgh and Baker 2011), and another facet that contributes to explain how capitalism is capable of reproducing consent in the midst of oppression and injustice. 
In his critical research on higher education, Bourdieu (1988) provides more insights to make sense of such a contradictory class location. He describes the universities as a structured field in which its agents compete for scarce resources and for the "legitimation of particular definitions and classifications of the social world" (23). Bourdieu considers academic labour as producing intellectual and cultural wealth that allows them to shape the way dominant ideology is communicated and recognized in a given society, which, for instance, manifests in the fact that higher education institutions administer a monopoly of certifications, making higher education an important reproductive apparatus of the given social order. Such intellectual and cultural capital is not automatically monetized, thus it requires continuous negotiations in terms of exchange rate with economic capital.

In relation to our argument, Bourdieu's interpretation of academic labour in the political economy of knowledge becomes particularly illuminating. For Bourdieu, academicians experience an important tension between the transformative and reproductive tendencies of knowledge production, exemplified by the tension between heterodoxa and hortodoxa:

It is only when the dominated have the material and symbolic means of rejecting the definition of the real that is imposed on them through logical structures reproducing the social structures (i.e. the state of the power relations) and to lift the (institutionalized or internalized) censorships which it implies [...] that the arbitrary principles of classification can appear as such and it therefore becomes necessary to undertake the work of conscious systematization and express rationalization which marks the passage from doxa to orthodoxy. Orthodoxy [...] opinion, which aims, without ever entirely succeeding, at restoring the primal state of doxa, exists only in the objective relationship which opposes it to heterodoxy $(1977,169)$.

While the contradiction between conservative and transformative knowledge can be attributed to different ideological understandings of academic knowledge production, it also frequently mirrors a stratification between senior established academic workers who try to conserve their position and junior professors who try to challenge those conservative positions via alternative and innovative knowledge. We will explore more in detail how the systemic pressures and the productive practices of the political economy of intellectual labour shape its workers. Thus, by providing an account of both the objective and subjective conditions of academic labour, we assert a materialist analysis of this specific kind of productive activity, by examining the intersection of individual agency and self-understanding within a framework of structural limitations.

\section{Subjective Academic Labourer and Consumptive Production}

In order to conceptualize how academic (knowledge) work furthers precarious positionalities and subjectivities, we need to take into account how this kind of labour frequently operates and enacts a state of class flux, according to which class positions are "not fixed, but dynamic, meaning that in informational capitalism, people have a fluid and transient class status" (Fuchs 2010, 189). Such a fluidity, we believe, signals a general condition of working impermanence that shapes the producing subject 
as well because the worker producing also produces its own consciousness (Marx 1857).

Because of this particular kind of knowledge work, together with the normal features of waged labour as a significant aspect of such creative and meaningful activity, the consciousness of academic labourers is likely to be constituted by the combination of the alienating implications of Marxian 'labour' and the more rewarding Marxian 'work' (Marx 1973). Through free work/labour, people organise their lives around 'creativity' and self-activation (Armano and Murgia 2017) and technology of self-hood (Gill 2014) where the external-direction logic - typical of the Fordist model - is replaced by a new sphere of participation, self-promotion of subjective resources, and self-responsabilization (Salecl 2010). As the concept pioneered by Terranova (2000) suggests, the very ironic multiple sense of being "free" allows our understanding of academicians to navigate in between both Marxian labour and work. We try to make sense of such a compound subjectivity by using the notion of free labour and how it translates into a subjective struggle for employability in which vocation and voluntary work push against debt and precarity.

The vocational aspect is key to understand the dialectics between important degrees of flexibility and freedom, and equally preponderant degrees of subordination and exploitation (Clarke et al. 2012). As Davies and Petersen (2005) observe, it is the voluntary vocation and the promise of a more stable future that makes the double process of subjectification - i.e. as acting subject and exploited 'object' - particularly insidious. Along the same line of argument, Berlant (2011) describes such a dynamic as cruel optimism that maintains professional expectations of recognition, career and work stability that the present academic cannot really guarantee. In those circumstances, the academic worker joins the general tendency of knowledge workers of investing in the construction and maintenance of instrumental social relations.

The dimension of the promise constitutes the persuasive optimistic narrative of the typical US academic career that starts with a lingering condition of debt. First of all, paying off student loans accumulated in the process of financing undergraduate education and for sustaining extra expenses not covered by the exiguous teaching and research assistantship salary; self-financing of most traveling expenses for conferences. Then, once earning a PhD, moving expenses due to temporary visiting appointments to hopefully land a tenure track position, and even more hopefully, being promoted to tenure. In such condition, the promise of a futurible stable position is what allegedly compensates for a perennial condition of debt. In this sense, Lazzarato, in Governing by Debt (2015), argues that under current capitalism, especially in the aftermath of 2008 economic crisis, debt is no longer primarily a question of budget and balance sheets, but a political relation of subjection and enslavement. Debt has gone beyond the numerical to almost approach ad-infinitum, thus implying the impossibility of its pay back. Debt becomes a political economic tool to discipline populations, classes and labour categories, and in this case, intellectual workers.

Academic subjectivities also experience a steady expansion of labour that develops through intensification and de-intensification moments (Gallino 2001). Furthermore, the colonization of previously considered disposable leisure time leads academicians to unpaid work based on such vocational passion of one's own work (Gill 2010; Clarke et al. 2012). Court and Kinman (2008) confirm such a tendency, reporting on a 2005 study corroborating that academics are the one professional category that experience unpaid overtime. As such, because precarious labourers often rely on an increase of labour time to tend to a loss a growing job security, class positionalities are formed based on who capitalizes on general knowledge while working the 
longest for the best available contract. Hence, "the emergence of this class is a characteristic expression of capital's movement under neoliberal conditions to outsource labour to reduce variable capital" (Fuchs 2010, 186).

Thus, the vocational aspect becomes a means of self-exploitation, which links meaningful jobs with partially de-waged value production (Hesmondhalgh and Baker 2011). While both academicians, in particular, and knowledge workers, in general, seem to be aware of the self-managing aspect (Gill 2010), there is indeed an aspect of false consciousness that leads academic workers to idealize work (McRobbie 2015) while carrying out practices of self-exploitation (Lorenz 2012). Again, we stress the previously mentioned need to 'rematerialize' mental labour, because it is such an idealization that allows its concealed (because self-enacted) exploitation (Huws 2014, 102).

However, self-exploitation and the vocational aspects are not simply due to false consciousness, but also to a system that re-signifies knowledge work in terms of employability. In this sense, academic work, from the subjective point of view, is a powerful exemplification of the promise of employability understood as the worker's capability to gain initial employment, maintain it, and continuously produce potential for recycling (Hillage and Pollard 1998).

Employability, then, becomes the subjective way in which the neoliberal restructuration of the job market, defined by flexibility, insecurity, and individualization, manifests (Finn 2000). Employability thus implies the shift of labour control and labour formation to individuals who become self-responsibilized and self-enacted (Giustiniano and Brunetta 2015), ergo, self-exploited: longings to subjectively take control and materially profit from their own life, individuals paradoxically strive to overcome their subjective alienation through mastering their accepted material alienation as a capitalist subject (Bloom 2013, 786). As a result, academic labourers act like reprogrammable workers (Castells 1996), which are continuously in need of updating and reskilling.

In our view, those concepts clustered around employability synthetize the peculiar dialectical combination between the vocational, creative and flexibility aspects, and the level of pressure that the political economy of intellectual labour exerts on its agents that is internalized in terms of self-responsabilization, self-motivation and both exploitation and self-exploitation, which Terranova (2000) powerfully synthetizes in the twofold mode of performing free labour: voluntary as free and unpaid (or underpaid) as for free. Here below, we examine one specific aspect that, in our view, is particularly telling of such conditions: academic publishing.

\subsection{Political Economy of Academic Publishing}

The academic 'free' worker is the one who can assert himself/herself in the world by the privilege of authorship, possibly understood as one evidence of capability of people making history, an apparent victory over alienated labour. That is because authorship, in its broadest sense, expresses a humanist sense of history centred around voluntarism and individual agency summarized by philosopher Pico della Mirandola's concept "homo faber sui" $(1942,192)$. However, as in the well-known Marxian principle on history making (Marx 1907, 5), on the one hand, when they can publish, they do not publish under the condition of their own making because they often forfeit their own property rights and their own argument to the particular politics of publication of a given journal; on the other when they fail to publish, they must frequently cope with violent rejection reviews that can perturb the spirit of the fiercest, stoic virtuoso. 
In the current political economy of journal publishing and knowledge work, especially in our field of communication and media studies, authors also lose control of their own production, thereby giving up intellectual property rights and having their words instrumentalized and decontextualized. As Striphas (2010) notes, "the political economy of academic journal publishing has impinged on cultural studies' capacity to transmit the knowledge it produces" (3) because of how it is constrained by necessities of capitalist accumulation in academia (Peekhaus 2012). As a result, as Wright Mills (1951) already denounced more than six decades ago, "the means of effective communication are being expropriated from the intellectual worker" (159).

The continued corporatization of academic journals resituates perpetual precarity by alienating knowledge workers who are attempting to solidify positions in academia while giving up the rights to their work. By transforming intellectual labour into economically viable property, intellectual workers are not only subject to publishing practices and mandates of their departments and tenure, but their work allows publishers to "compete with one another in the marketplace" (Striphas 2010, 6). As academic journals continue to be subject to a growing neo-liberal regime, academic knowledge workers are not only continuously constrained to a capitalist controlled industry, but their work continues to be viewed as a characteristic of the utility of science as measured according to a market criteria (Etzkowitz, Webster and Healey 1998). By being forced to participate in producing knowledge that is not only marketable to the political economy of publication but also profitable, academic knowledge workers have continued to be plagued by the growing fragmentation of academic departments and a continued niche approach to scholarly publication (Readings 1996; Brown, Griffiths and Rascoff 2007).

Striphas (2010) situates academic publishing into five major trends, namely alienation, proliferation, consolidation, pricing, and digitization. For academic knowledge workers who need the publishing industry as a means to justify their positions in the academy, the continuation of knowledge accumulation has allowed capital to permeate the industry of publishing in commercial logic. The continued neo-liberal practices of academic publishing are crucial in highlighting the tensions that exist for knowledge workers because they demonstrate contemporary processes of accumulation and the expanding capitalist control of social production that move to include new strata of producers beyond the "orthodox Marxist emphasis on the industrial proletariat and waged labor" (Peekhaus 2012, 587).

Furthermore, the critical relationship mentioned earlier between orthodoxa and heterodoxa kinds of knowledge also provides a politico-economic explanation related to our considerations on the conditional position of critique. In fact, un-established intellectuals in the field experience a fundamental tension between differentiation and legitimation that reveals the contradictory nature of cultural capital: cultural capital needs to both negate existing knowledge to become desirable (because novelty relates to the progress of knowledge, and because academia lives the enlightenment myth that the best idea will prevail through struggle, so 'novelty' sometimes uncritically translates into 'good'), but also needs validation vis-à-vis established knowledge.

Compared to the task of teaching and serving at various levels of academic institutions (e.g. department, college and university), it is in the context of publishing that academic work reveals the most insidious sides of knowledge work: as a work that becomes boundless, as it becomes the kind of production that relocates in the interstitial space between work place and home, public and private sphere, and maintains academic workers always in 'on-line' status. 


\subsection{The Political Economy of Teaching}

While the production and publication of new knowledge represents a distinctive characteristic of them, most academicians work in institutions who employ them for the most part as teachers thus prevalently engaged in re-production rather than production of knowledge. Their task as instructors reflect once again a contradictory class location worth to be considered. On the one hand, academicians may consider themselves as inhabiting a managerial position of control and leadership. First of all, in the sense of directing the pedagogic projects/objectives linked to a university course, which manifest in the shaping of syllabi activities. Second, through a constant system of evaluation and disciplinization, teachers shape and 'subject' individuals, thus contributing to the societal apparatus that make people 'docile bodies' (Foucault 1977). Thirdly, the process of reproduction of knowledge through attending courses and credits gaining, and the various technique of evaluation is productive as cultural capital, thus placing academicians in key managerial positions in the political economy of certification which allow students to gain access to better paid occupations.

On the other hand, teaching in a neoliberal environment, especially pronounced in the US, reveals how the subjection process previously mentioned also concerns academicians as well. In fact, the commodification of higher education produces an interesting process that alienates teachers from the just mentioned power/control over knowledge production and 'emancipates' students by significantly reconfiguring the relations of production. Teachers tend to increasingly lose control over the pedagogy and academic freedom because they become retailers of educational commodities, thus turning syllabi into de facto contracts with quasi legal binding. Students become demanding customers who definitively enjoy the progressive side that capitalism, with eternal revolutionizing conveys. Thus, paradoxically enough, the neoliberalization of education carries a twisted and partial emancipation of students from the power-relations based on the principle of authority of the traditional teacherstudents rapport that Freire (1970) so strongly denounced.

\section{Conclusions: A Dialectical Narrative}

According to Nancy Fraser, progressive forces supportive of the mainstream trends of new social movements dedicated to the defence of identity politics - i.e. feminism, anti-racism, multiculturalism, and LGBTQ rights - have allied themselves with financial and cognitive capital. The outcome, as Fraser (2017) puts it, shows that "unwittingly, the former lends their charisma to the latter. Ideals like diversity and empowerment, which could in principle serve different ends, now gloss policies that have devastated manufacturing and what were once middle-class lives." Liberalindividualist understandings of "progress", so well represented in the highly contradictory California ideology (Barbrook and Cameron 1996) and the Clinton's saga, gradually replaced the more expansive, anti-hierarchical, egalitarian, class-sensitive, anticapitalist understandings of emancipation that had flourished in the 1960s and 1970s. In this sense, while concentrating on the US humanities for this analysis, and with rapprochements coming from both the radical right and radical left, humanities academicians are considered not only as hypocritical due to a preaching of social reform out a position of privilege, but also as an important representative of the so called "progressive neoliberalism" that Fraser (2017) contends therefore, aware and, most importantly, unaware artificers of neoliberal hegemony.

As we mentioned earlier, the dialectics of intellectual labour seems to be a distinctive feature of this profession, which has been also aggravated by recent drastic changes in the economic and social experience of the academic worker. The contra- 
dictory class positionality of academic knowledge workers has led to growing instability in finding permanent work while the knowledge labour produced continues to necessarily function as commodity exchange for financial capital and stability. At the same time, with a growing sentiment of rejection of this profession armed by antiintellectualist rhetoric, scholars continue to push through the pressures of academic departments operating in staunch neoliberal conditions. Hence, while academic labour experiences higher and higher level of capital subsumption - thus in many ways more integrated with dominant dynamics of cognitive/knowledge/informational capital accumulation, its liminal position still cannot find a comfortable place in the social organisation of production.

We claimed that those 'objective' conditions contribute to shape subjectivities that are impacted by import forces such as a continuous condition of debt; the constant struggle to maintain 'employability,' a considerable degree of intellectual property rights and intellectual freedom, a drastic re-configuration of the teacher-student relationship and loss of academic freedom. Thus, academic production, intellectual labour and work, the political economy of publishing and teaching, and the goal of obtaining 'employability' are all factors that continue to add to the precarious nature of workers in academia.

We tried to point out both 'objective' and 'subjective' levels of intellectual labour by centring our focus on material production in the academy. We tried to illuminate how the historical valorization of knowledge production and reproduction continues to push a post-Fordist intellectual capitalism that forces academic workers to capitalize on all available intellectual and cognitive abilities. Further, the influence of such an 'intellectualized' capitalism not only allows for the colonization of disposable leisure time, but becomes the driving force behind the need for self-exploitation in a political economy of publishing that continues to centralize itself around increased subjective alienation. The contradictory nature of academic validation and economic security in the continuously exploited academy are sites of contention that not only drive the precarious positionality of the intellectual worker, but also force the academic worker to experience increasingly unstable academic departments.

More specifically related to our field of study, while capitalism is consistently inhabited by profound contradictions that create crises and rupture points, we also tried to incorporate communication and media studies both as a discipline as well as labour into a dialectical understanding of the social whole. We think that such a communicative perspective is necessary in a moment in which a new spirit of capitalism (Boltanski and Chiappello 2007) so effectively subsumes its own contradictions as extending the process of value creation to the entirety of social life (Dyer-Witheford 1999). Such permeation flattens the world into a one-dimensional playground in which commodified culture tends to lose its function as a positive estrangement moment (Marcuse 1964).

Finally, by defining academicians as specialized representatives of knowledge work, thus as labourers, means to push back against two idealist notions. The first one conveyed by the figure of the "traditional intellectual" in a Gramscian sense $(1975,474)$ which assumes to be outside history, beyond ideological dispute, and, in doing so, reifies the existing hegemony. The second one conveyed by a distortion of Gramsci's "organic intellectual" $(1975,476)$, which materializes in the socially responsible progressive public intellectual, who intervenes in the world based on an abstract notion of social justice, equality and 'power,' and who, out of vocation, ideals, and ideology, needs to find a normative justification of his/her occupation outside of it. Such a conceptualization represents, in our view, the opposite of what an organ- 
ic intellectual should aspire to, and in the end turns out to be another version of the traditional intellectual. That is because such a notion assumes academicians to behave as intellectual archangels coming down to earth to save the world instead of being subjects completely embedded in the whole social process as workers.

While for Gramsci we are all involved in some intellectual activity, we cannot all function as organic intellectuals, and this is true for academic workers as well. The automatic identification of our intellectual labour, with the political function attributed by Gramsci to intellectuals, should not be considered as a given. Clearly, we are not saying that academicians should not get involved in political projects, but rather, that we believe that mobilization should have a degree of organicity with the class they belong to, and therefore, starting from the particular location in the material production of a given society. It is in fact in the material terrain of working that one becomes aware of the larger social contradictions based on class specific condition of exploitation and precarization of work (Archer 2008). In this sense, Autonomist Marxism literature (e.g. Hardt and Negri 2000; Berardi 2009) points out how specific the postFordist conditions of production, together with the specific subjectivities of workers valorizing knowledge, culture and relational skills, possesses an emancipatory potential to develop a critical consciousness that can challenge present capitalism.

In the academic world, this is exemplified by the kind of mobilization enacted by initiatives such as Precarious Workers Brigades and Carrot Workers Collective (2014) in the UK, Quinto Stato in Italy, or the Cultural Workers Organize in Canada and their effort to produce a number of practical tools to survive as knowledge workers, while denouncing how higher education is normalizing precarity.

\section{References}

Archer, Louise. 2008. The New Neoliberal Subjects? Young/er Academics' Constructions of Professional Identity. Journal of Education Policy 23 (3): 265-285.

Armano, Emiliana and Annalisa Murgia. 2017. Hybrid Areas of Work in Italy. Hypotheses to Interpret the Transformations of Precariousness and Subjectivity. In Mapping Precariousness, Labour Insecurity and Uncertain Livelihoods: Subjectivities and Resistance, edited by Emiliana Armano, Arianna Bove and Annalisa Murgia, 47-59. London: Routledge.

Barbrook, Richard and Andy Cameron. 1996. The Californian Ideology. Science as Culture 6 (1): 44-72.

Beck, Ulrich. 2000. What is Globalization? Hoboken: Wiley Publishing.

Berardi, Franco. 2009. Precarious Rhapsody, Semiocapitalism and the Pathologies of the Post-Alpha Generation. London: Minor Compositions.

Berlant, Lauren. 2011. Cruel Optimism. Durham: Duke University Press.

Bloom, Peter. 2013. Fight for Your Alienation: The Fantasy of Employability and the Ironic Struggle for Self-Exploitation. ephemera: theory \& politics in organization 13 (4): 785-807.

Boltanski, Luc and Eve Chiapello. 2007. The New Spirit of Capitalism. London: Verso.

Bourdieu, Pierre. 1988. Homo Academicus. Stanford: Stanford University Press.

Bourdieu, Pierre. 1977. Outline of a Theory of Practice. Cambridge: Cambridge University Press.

Bratich, Jack Z. 2008. From Embedded to Machinic Intellectuals: Communication Studies and General Intellect. Communication and Critical/Cultural Studies 5 (1): 24-45.

Briziarelli, Marco. 2013. (Re-)Occupy Critique! The Condition of Theory and Praxis in Contemporary American Academia. Graduate Journal of Social Science 10 (3): 54-79.

Brown, Laura, Rebecca Griffiths and Matthew Rascoff. 2007. University Publishing in a Digital Age. Journal of Electronic Publishing 10 (3). Accessed September 27, 2017. https://doi.org/10.3998/3336451.0010.301 
Castells, Manuel. 1996. The Rise of the Network Society: The Information Age: Economy, Society, and Culture. Hoboken: Wiley Publishing.

Clarke, Caroline, David Knights and Carol Jarvis. 2012. A Labour of Love? Academics in Business Schools. Scandinavian Journal of Management 28 (1): 5-15.

Court, Stephen and Gall Kinman. 2008. Tackling Stress in Higher Education. London: University and College Union. Accessed September 27, 2017. https://www.ucu.org.uk/media/3021/Tackling-stress-in-higher-education-UCU-surveyfindings-Dec-08/pdf/ucu hestress dec08.pdf

Davies, Bronwyn and Eva B. Petersen. 2005. Intellectual Workers (Un)Doing Neoliberal Discourse. Critical Psychology 13: 32-54.

Denning, Michael. 2004. Culture in the Age of Three Worlds. New York: Verso.

Discenna, Thomas. 2011. Academic Labor and the Literature of Discontent in Communication. International Journal of Communication 5: 1843-1852. Accessed September 27, 2017. http://ijoc.org/index.php/ijoc/article/view/1301/661

Dyer-Witheford, Nick. 1999. Cyber-Marx. Cycles and Circuits of Struggle in High Technology Capitalism. Urbana: University of Illinois Press.

Eagleton, Terry. 2000. The Idea of Culture. London: Wiley.

Etzkowitz, Henry, Andrew Webster and Peter Healey, ed. 1998. Capitalizing Knowledge: New Intersections of Industry and Academia. Albany: State University of New York Press.

Finn, Dann. 2000. From Full Employment to Employability: A New Deal for Britain's Unemployed? International Journal of Manpower 21 (5): 384-399.

Foucault, Michel. 1977. Discipline and Punish. The Birth of the Prison. Harmondsworth: Penguin Books.

Fraser, Nancy. 2017. Against Progressive Neoliberalism, A New Progressive Populism. Dissent, January 28. https://www.dissentmagazine.org/online articles/nancy-fraser-againstprogressive-neoliberalism-progressive-populism

Freire, Paulo. 1970. Pedagogy of the Oppressed. New York: Continuum.

Fuchs, Christian. 2016. Critical Theory of Communication: New Readings of Lukács, Adorno, Marcuse, Honneth and Habermas in the Age of the Internet. London: University of Westminster Press.

Fuchs, Christian. 2010. Labour in Informational Capitalism and on the Internet. The Information Society 26 (3): 179-196.

Fuchs, Christian. 2009. Information and Communication Technologies and Society: A Contribution to the Critique of the Political Economy of the Internet. European Journal of Communication 24 (1): 69-87.

Gallino, Luciano. 2001. The Human Cost of Flexibility. Rome: Editori Laterza.

Gill, Rosalind. 2014. Academics, Cultural Workers and Critical Labour Studies. Journal of Cultural Economy 7 (1): 12-30.

Gill, Rosalind. 2010. Breaking the Silence: The Hidden Injuries of the Neoliberal University. In Secrecy and Silence in the Research Process: Feminist Reflections, edited by Róisín Ryan-Flood and Rosalind Gill, 228-244. London: Routledge.

Giustiniano, Luca and Federica Brunetta. 2015. Rethinking Employability: New Managerial Competencies in a Global Labour Market. Sociologia del lavoro 137: 17-35.

Gorz, Andre. 2010. The Immaterial. Chicago: University of Chicago Press.

Gramsci, Antonio. 1975. Quaderni dal Carcere. Turin: Einaudi.

Hall, Stuart. 1992. The Question of Cultural Identity. In Modernity and its Futures, edited by Stuart Hall, David Held and Anthony McGrew, 274-316. Cambridge: Polity Press.

Hardt, Michael and Antonio Negri. 2004. Multitude. New York: Penguin.

Hardt, Michael and Antonio Negri. 2000. Empire. Cambridge: Harvard University Press.

Hesmondhalgh, David and Sarah Baker. 2011. Creative Labour: Media Work in Three Cultural Industries. London: Routledge.

Hillage, Jim and Emma Pollard. 1998. Employability: Developing a Framework for Policy Analysis. Suffolk: Department for Education and Employment. 
Horkheimer, Max and Theodor Adorno. 1974. The Dialectics of Enlightenment. London: Verso.

Huws, Ursula. 2014. Labor in the Global Digital Economy: The Cybertariat Comes of Age. New York: Monthly Review Press.

Koloğlugil, Serhat. 2015. Digitizing Karl Marx: The New Political Economy of General Intellect and Immaterial Labor. Rethinking Marxism 27 (1): 123-137.

Lazzarato, Maurizio. 2015. Governing by Debt. Los Angeles: Semiotext(e).

Lazzarato, Maurizio. 1996. Immaterial Labor. In Radical Thought in Italy: A Potential Politics, edited by Paolo Virno and Michael Hardt, 133-146. Minneapolis: University of Minnesota Press.

Lorenz, Chris. 2012. If You're So Smart, Why Are You Under Surveillance? Universities, Neoliberalism, and New Public Management. Critical Inquiry 38 (3): 599-629.

Marcuse, Herbert. 1964. One Dimensional Man: Studies in the Ideology of Advanced Societies. New York: Beacon Press.

Marx, Karl. 1990. Capital: A Critique of Political Economy, Volume 1. New York: Penguin.

Marx, Karl. 1973. Grundrisse. London: Penguin.

Marx, Karl. 1907. The Eighteenth Brumaire of Lois Bonaparte. New York: Charles H. Kerr \& Co.

McRobbie, Angela. 2015. Be Creative: Making a Living in the New Culture Industries. London: Polity.

Peekhaus, Wilhelm. 2012. The Enclosure and Alienation of Academic Publishing: Lessons for the Professoriate. tripleC: Communication, Capitalism \& Critique 10 (2): 577-599. Accessed September 27, 2017. http://www.triple-c.at/index.php/tripleC/article/view/395

Pico della Mirandola, Giovanni. 1942. De hominis dignitate, Heptaplus, De ente et uno e scritti vari. Florence: Vallechi.

Precarious Workers Brigade and Carrot Workers Collective. 2014. Free Labour Syndrome. Volunteer Work and Unpaid Overtime in the Creative and Cultural Sector. In Joy Forever: The Political Economy of Social Creativity, edited by Michał Kozłowski, Angieszka Kurant, Jan Sowa, Krystian Szadkowski and Jakub Szreder, 211-226. London: MayFlyBooks.

Radder, Hans. 2010. The Commodification of Academic Research: Science and the Modern University. Pittsburgh: University of Pittsburgh Press.

Readings, Bill. 1996. The University in Ruins. Cambridge: Harvard University Press.

Said, Edward. 1993. Culture and Imperialism. London: Chatto and Windus.

Salecl, Renata. 2010. The Tiranny Choice. London: Profile Books.

Striphas, Ted. 2010. Acknowledged Goods: Cultural Studies and the Politics of Academic Journal Publishing. Communication and Critical/Cultural Studies 7 (1): 3-25.

Terranova, Tiziana. 2000. Free Labour: Producing Culture for the Digital Economy. Social Text 18 (2): 33-57.

Virno, Paolo. 1996. Notes on the "General Intellect". In Marxism beyond Marxism, edited by Saree Makdisi, Cesare Casarino and Rebecca Karl, 265-272. London: Routledge.

Wright, Erik Olin. 1997. Class Counts. Comparative Studies in Class Analysis. Cambridge: Cambridge University Press.

Wright Mills, Charles. 1951. White Collar: The American Middle Classes. Oxford: Oxford University Press.

\section{About the Authors}

\section{Marco Briziarelli}

Marco Briziarelli studies critical approaches to media and communication theory, especially as these fields intersect with broader issues in political and social theory, intellectual and cultural history. The work he has published in the last years has consistently tried to articulate the link between two united but distinct research interests, namely political economy of (digital) media and media and social movements. 
Joseph L. Flores

Joseph L. Flores received his BA (2011) and MA (2015) degrees from the University of Texas at El Paso. With a broad interest in political, cultural and social theory, Joseph takes a critical approach to understanding how communication impacts social media use, social movements and digital labour. Specifically, he is interested in political and social discourse through mediated forms of communication that carry social, political and cultural consequences. 


\title{
Digital Labour in the University: Understanding the Trans- formations of Academic Work in the UK
}

\author{
Jamie Woodcock
}

London School of Economics and Political Science, London, UK, j.woodcock@lse.ac.uk, www.jamiewoodcock.net

\begin{abstract}
Universities have been the site of a variety of shifts and transformations in the previous few decades. Both the composition of students and academics are changing (to a lesser or greater extent), along with the ways in which teaching and research is supported, conducted, and delivered. The effects of neoliberalism, privatisation, precarious employment, debt, and digitalisation have been highlighted as important factors in understanding these changes. However, the ways in which these tendencies are expressed in universities - both in specific and general ways - remain fragmented and under-analysed. In particular, the role of academic labour processes, increasingly mediated through digital technology, remains in the background. There is a risk of viewing these transformations as abstracted, far removed from the day-to-day activities of academic labour on which universities rely. This article will therefore focus on connecting the broader changes in funding, organisation, and digital technology to the labour processes of academics. Rather than seeking a return to a romanticised pre-neoliberal university, this article explores the possibilities of resistance and alternatives to the university as it is now.
\end{abstract}

Keywords: Digital Labour, Academia, Autonomism, Work, Labour Process

\section{Introduction}

The university has been the site of a variety of shifts and transformations in the previous few decades. Both the composition of students and academics are changing (to a lesser or greater extent), along with the ways in which teaching and research is supported, conducted, and delivered. There are two key dynamics that will be examined in this paper: the neoliberalisation of the university with new management techniques and strategies, and the introduction of new digital technologies. These two dynamics are closely bound up with each other and are transforming not only the university, but also the forms of academic work.

The university has been a space from which much research on digital labour has originated, yet as a research site it remains comparatively understudied in this context. The focus of much research has been on the neoliberalisation of the university, in the sense of the political economy of higher education, with less on the effects of technology that are also bound up with these processes. As Morgan and Baert (2015) note, too often universities are considered through 'tired clichés' as "ivory towers"' and "dreaming spires"', leading to an 'unhelpful black-boxing of these zones of social life from attentive sociological enquiry, usually on the odd assumption that the "real world" is somehow always going on elsewhere.' For example, labour process theory originated in universities, seeking to uncover what Marx $(1990 / 1867,280)$ called the 'hidden abode' of exploitation at work, yet the site from which the research takes place remains obscured to this analytical lens.

There is a deep irony in the lack of application of the conceptual tools of labour process analysis and other ways of studying work to the academic environment itself. 
Furthermore, this irony continues with the overwork of academics who write not only about work, but increasingly about anti-work politics. The patterns of work may be accelerating, but the way in which the work is carried out is also transforming through the application of digital technologies.

The aim of this article, therefore, is to analyse academic work and its transformation within the university. This begins with discussion on how technology is transforming work, the role of knowledge, and universities under capitalism. The next part situates academic work, particularly in the UK, within the broader dynamics of neoliberalism. After discussing this context, the article moves on to specifically discussing the contemporary academic labour process. The final section analyses these changes through the lens of class composition, suggesting future directions for research.

\section{Knowledge at Work}

For Marx (1991/1894, 1017), the labour process was an important starting point for analysis, because 'its simple elements remain common to all social forms of development.' Thus, even when examining the complex digital technologies found today, the labour process remains a key way to understand how capitalism has developed in various ways. When addressing questions of work in the university, the analysis is concerned with processes of knowledge construction. However, with Marx, there was 'no detailed discussion of the institution of the university, higher education, or academic research', and only a 'mention of scientists employed by capitalists in privately organized institutions' (Szadkowski 2016b, 12). Despite the application of terms 'knowledge work' or 'knowledge economy' (Nonaka 1998), it is important not to exceptionalise academic labour as though knowledge and information is not used in other forms of work. For example, the role of information in the factory was identified as key by Romano Alquati $(1975,113$; quoted in Wright 2016, 4), who argued that:

Information is the most important thing [l'essenziale] about labour-power: it is what the worker, by means of constant capital, transmits to the means of production upon the basis of evaluations, measures, elaborations, in order to work [operare] upon the object of labour all those changes in form that give it the use value required. The 'disposability' of the worker leads him to be a qualitative indice of socially necessary labour time, by which the 'product' is valued as the 'recipient' of a certain quantity of 'information'.

This takes a very different approach to many of the studies of the labour process in the factory, often focusing on the physical labour process and methods of discipline and control. Similarly, the importance of information has been argued for by Castells $(2000$, 17 ), stating that 'knowledge and information are critical elements in all modes of development, since the process of production is always based on some level of knowledge in the processing of information.' However, as Pasquinelli $(2011,4)$ has noted, what Alquati introduces is the "concept of valorising information [...] as the "flow" running along and feeding those circuits' in the factory.

The importance of information in the production process was also noted by Frederick Taylor, albeit from the perspective of capital. As part of the preparation of scientific management, Taylor $(1967,36)$ argued for the 'gathering together all of the traditional knowledge which in the past has been possessed by the workmen.' This process of knowledge theft from workers by managers was carried out in practice by Taylor during 
his experiments at the Midvale Steel Company, in which he worked on machine lathes trying to understand the labour process from the shop floor. Clearly, the importance of information therefore pre-dates the rise of contemporary digital technology. For Alquati, the importance of information was twofold. First as 'control information', analogous to the knowledge theft of Taylorism outlined above. The second is information 'that constitutes the collective legacy of the working class [...] productive information tout court' (Alquati 1975, 114; quoted in Wright 2016, 5), that which capital attempts to subsume and transform into the former. Alquati's prescient analysis focuses on the way in which this valorised information 'enters the cybernetic machine and it is transformed into a sort of machinic knowledge' (Pasquinelli 2011, 5). This involves the ability to 'encode workers' knowledge into bits and consequently transform bits into numbers for economic planning', or as Pasquinelli $(2011,5)$ puts it: 'cybernetic code transforms information into value.'

The development of digital technology has been driven by a combination of the military, research intensive universities, and the defence industries, while being 'mediated, ironically, by hacking and homebrew computing cultures that believed "information wants to be free"' and 'Silicon Valley culture' (Dyer-Witheford 2010, 488). This belief in the freedom of information ties into Marx's (1976/1857, 690-712) discussion of the 'general intellect' found in the 'fragment on the machines.' Virno (2001) argues that the idea of the 'general intellect' entails the claim that 'due to its autonomy from it, abstract knowledge [...] is in the process of becoming no less than the main force of production and will soon relegate the repetitious labour of the assembly line to the fringes.' This is a potential of automation: to increase the autonomy of workers, freeing them from the kinds of work that have previously been dominant. However, as Virno (2001) continues, the realisation of this tendency arrives with 'no revolutionary or even conflictual implication.' Tronti (1965) argued that the 'political history of capital' can be read as a 'history of the successive attempts of the capitalist class to emancipate itself from the working class.' This is expressed in the long-term tendency towards the increase in the ratio between constant capital (raw material and machines) and variable capital (or living labour), discussed by Marx $(1977,762)$ as the organic composition of capital. Although in the contemporary context, Dyer-Witheford $(2010,494)$ suggests it would perhaps be better to term this the 'inorganic composition of capital', given the rise of automated and automating machines. This is especially pertinent when considering the claim that robots or algorithms are coming to replace workers, for example found in the recent claim that $47 \%$ of jobs are at risk of being automated (Frey and Osborne 2013).

The contemporary transformation of work has involved the introduction of new types of technology and management practices. In this context, the application of technology involves the augmentation of the labour process in various ways, and can clearly be seen with office work. As Huws $(2001,7)$ has noted, office work (despite the challenges of clearly delineated it) has been subjected to a range of transformations, from the 'impact of the restructuring of markets', 'the ideological triumph of neoliberalism', to the 'impact of technological change.' For Handy (1984), the application of digital technology was claimed to be the start of a positive transformation of work. However, the reality has become closer to that identified by Braverman (1999): the degradation and deskilling of work under managerial control. New technologies have reduced paperwork and increased the pace of tasks, in effect augmenting the labour process by automating parts of it, and there have been increasing applications of technology for supervision and control. For example, Bain et al. $(2002,3)$ previously noted that it is now "feasible to attain total knowledge, in "real time", of how every employee's time was 
being deployed, through the application of electronic monitoring equipment.' In the example of call centres, the possibilities of these new surveillance technologies have been captured by Fernie and Metcalf $(1997,3)$ as being like an 'electronic panopticon.'

The role of knowledge and information - and attempts at control and surveillance are clearly important in the context of a university. These institutions of higher education have historically served two functions: the construction of knowledge through research and the provision of teaching and training. Broadly speaking, universities began as elite institutions, training the next generation of the ruling class and providing ideological resources. From the 1960s onwards, universities in the UK shifted to the provision of mass education, with greatly increasing numbers of students. Universities have therefore been considered public institutions, separate from the market, and in the UK, formally separate from the state itself. However, the widespread changes that are captured with the often-clumsy designation of neoliberalism, has involved widespread changes to the university. Roggero $(2011,3)$ identified three key trends: the first is a blurring or collapsing of the public/private distinction in universities, with the integration of market forces and private interests. The second is the failure of the university as 'an elevator for social mobility', with a university degree no longer able to offer better employment prospects, becoming 'necessary to access even a precarious job.' With this change students are much less likely to conform to stereotypes of being lazy and living off government grants, with many no longer 'the classic figure of worker-in-training' but a precarious worker already. Thirdly, there is a crisis in the production of knowledge itself in the university, something seen most clearly with the failure of economics to predict, understand, or respond to the most recent economic crisis. This is part of a broader intellectual 'crisis of the modern disciplines' (Ibid.).

There is a long history of universities in the UK and a risk in over emphasising a romanticised notion what they involve. The existence of universities under capitalism has involved attempts to subsume research and teaching under the imperatives of capital. At first this involved elite training, but now universities play an increasingly larger role. In the current global higher education environment, UK universities remain public sector organisations and charities, but increasingly compete or collaborate with the private sector. The shift towards a knowledge based economy has involved pressure to 'reorient university teaching and research from alleged ivory-towered intellectual isolation towards closer and more continuous contact with the economy', however the 'university-corporate ties' in the USA go back until the eighteenth century (Jessop $2017,855)$. For example, Cooke (1910) at the turn of the twentieth century, sought to apply Taylors scientific management techniques to the university. As Szadkowski (2016a) argues, control over and improving the effectiveness of academic labor are two long-term objectives in academia. What began with Cooke's research, was part of a larger trend to move academic institutions out of the crisis caused by both their overall financial decline and their lack of credibility where the general public was concerned (lbid.).

The application of Taylorist methods faces problems in terms of the measurability of academic work. The ability to take accurate measurements is a key part of Taylorism, often associated with the white-coated technicians standing over workers with stopwatches. As Beer $(2016,45)$ argues, 'measurement has the dual role of both capturing and setting standards, it records and produces.' The indeterminacy of labour power has been the key challenge of management since the first time a worker sold their time to a capitalist. The problem stems from buying labour-power from workers, but on trying to extract the maximum value from these purchases, discovering that it remains embodied in actual workers for whom working that hard is not in their interest. 
Often this is discussed in terms of motivation, but the 'inevitability of soldiering' - that workers are always trying to find a way to slow down - was a primary concern for Taylor (1967). The history of management has involved further attempts to solve this problem, but the first step is one of knowledge: needing to measure to be able to compare and attempt to speed up work. The same is true in universities: how can the use of academic labour be maximised without understanding what that labour is actually doing?

The use of digital technologies has greatly eased the possibilities of collecting, collating, and comparing statistics and metrics. In universities, a key rating has been citations - how many times articles have referenced a piece of research. As Pasquinelli (2009) has showed, experiments with methods to count citations provided the basis for Google's PageRank algorithm. It is therefore not enough to simply produce an academic output - for example, a journal article - but that output itself has to be measured along a variety of metrics: the quality of the journal in which it was published, the number of times it has been cited (in where the citing paper was published), and so on. This produces individual rankings for academics but also league tables between universities on a global level. As Szadkowski (2016a) points out, rankings by Thomson Reuters databases 'create a template for the measurement of the value of social relations in global academia, at the same time, they are used as a strict point of reference during national and institutional processes of evaluation of higher education systems, institutions and individual academics.' The measurement of academic output is generating vast amounts of metadata, something which allows for the 'measure of the value of social relations and a mechanism of social control' (Pasquinelli 2015, 63).

The use of these kinds of publication metrics have created 'publish or perish' pressures, leaving 'an indelible mark on contemporary academic life' (Fatsis 2016). This has been furthered by the 'interconnection between the academic journal publishing market and the global rankings' (Szadkowksi 2016a). The control over this aspect of measuring academic labour, along with enclosing much publicly funded research behind paywalls accessible only with extortionate fees, has proven a successful model for academic publishing. For example, Beverungen et al. $(2012,931)$ found that academic publishers could achieve as high as $40 \%$ margins. This is achieved by drawing on unpaid academic labour, exploiting the writing, editing, reviewing, and other activities without directly paying these vital parts, other than allowing access to metric rankings. For Szadkowski (2016a), this enclosure of academic research is part of a broader attempt by capital to first 'measure' and then 'appropriate the common.'

\section{The UK Context}

The contemporary landscape of universities in the UK has gone through a series of seismic shifts, the long-term impact of which is far from clear at this present moment. In this context, it is important to remember the primary concerns of universities: teaching, learning, and research. As Andrew McGettigan (2013) has highlighted, there is a long history of managerial audit culture in universities. This intensified with the introduction of the RAE (Research Assessment Exercise) and later the REF (Research Excellence Framework) that measures and compares academic research outputs across the UK. This is now going to be followed up with a teaching version: the TEF (Teaching Excellence Framework). This proliferation of numerical measurements, key performance indicators, and exit surveys has shifted the emphasis in universities towards quantitative outputs. This has been greatly facilitated by the proliferation of digital technologies, creating more opportunities for the generation, capture, and analysis of data. Across different disciplines there are increasing pressures to instrumentalise 
teaching and learning to cater to more employment focused elements as opposed to analysis and critique.

The risk of relying on statistics analysis is twofold, it fragments perspectives on university education, but there is also a question of whether statistics are actually measuring what they are intended to. At this point it is worth briefly considering the NSS (National Student Survey), the exit survey for final year undergraduate students used in the UK. Lee Harvey (2003) - the former director of research and evaluation of the Higher Education Academy - argued that when the NSS was being considered, 'the proposed national satisfaction poll would be a costly and pointless exercise [...] an unacceptable intrusion into university life that will damage existing improvement processes based on internal explorations of student satisfaction.' After the NSS had become a dominant indicator in the sector, Harvey (2008) again responded that the NSS was 'rapidly descending into a farce.' London Metropolitan University and Kingston University became embroiled in scandals of institutional manipulation and it is likely that many more have attempted subtler ways to influence their students. This is not an argument against consulting students about their opinions on education - far from it rather the effects of doing it in this way. Furedi and Attwood (2012) point out that the NSS 'possesses a corrosive immediacy that encourages the subordination of education and scholarship to the arbitrary imperative of student satisfaction.' Indeed, Bailey $(2013,143)$ has confirmed that 'the student experience' has become a 'leitmotif in pedagogical research.'

The problem with satisfaction is that it emphasises the consumption of education. Students are positioned as relatively passively consumers of an education that is packaged and delivered by academics. The comparison between institutions has a homogenising effect; experimentation is a risk and it is much safer to only make smaller modifications. This closes down potential alternative ways of organising teaching and learning, and in the process is narrowing the horizons of higher education. As Collini (2012, 17) has argued, universities are now struck by an 'obsession with global "league table" of universities' driven by 'subjective and inadequate opinion surveys' which 'provide little information that is both reliable and useful.' Furthermore, Collini $(2012,185)$ suggests that the notion of 'student satisfaction' is itself highly problematic, reducing the experience of teaching and learning to 'a set of "preferences" as reported on a tick-box questionnaire' aligned with the idea of satisfaction. This is a strange notion in education, as Collini (lbid.) points out, 'a "satisfied" student is nigh-on ineducable.' This reduces teaching to an exchange, a purchase, as if you can buy something as indeterminable as a learning experience.

The REF and the TEF are the clearest examples of metrics that have been introduced in the UK and play an important role in measuring the outputs of academics. As Burrows (2012) has argued, the metrics have combined with markets and affects in universities in the UK to form a kind of 'quantified control.' This includes the use of multiple metrics, citations of papers, regular assessment from outside the university and by students, modelling workloads, distribution of research funding, costing models, league tables, and so on to introduce market pressures into universities in the UK.

The success in measuring and comparing academics and universities in the UK has provided the basis for planning future changes. 'Success' in this context is considered as the ability to boil down the complexity of teaching and research to single digit measurements, allowing easy comparisons to be made without prior knowledge of the institutions or disciplines (Collini 2012, 37). The real success of these metrics has not been to provide meaningful comparisons between diverse subject areas or institutions, but to create competition which, as McGettigan $(2013,12)$ argues, 'will lead to upheaval: 
transforming institutions from within but also from without.' In other words, through these policies, 'the government is taking a huge gamble with England's universities, introducing uncertainty into a stable and productive system, though one not without faults' (McGettigan 2013, 22). For academic working in universities it has also introduced pressures that allow the interests of capital and management to become deeply written into their activities.

\section{The Academic Labour Process}

After looking at the broader context of what is happening in universities in the UK, the next part of this paper focuses down on the labour process of academics and its transformation through the application of digital technology. As Szadkowski (2016b, 9) points out, a critical project in a university needs to begin 'primarily' with 'the categories of academic living labour/knowledge, as both the source of social wealth, as well as the source of capital'. Furthermore, Winn $(2014,2)$ notes that on the subject of academic work, 'there is relatively little critical engagement with labour itself as the object of critique.' By returning the analysis to the labour process, and seeking to understand how this is changed by the dynamics discussed above, along with the introduction of new technology, this section seeks to discuss academic work in a new light. For Marx $(1990,284)$, the labour process involved three simple elements: first, the 'purposeful activity, that is work itself'; second, the 'objects on which that work is performed'; and third, the 'instruments of that work.'

The 'purposeful activity' of academic work is broadly divided into three parts: research, teaching, and administration. Due in part to digitalisation, each of these activities have been 'accelerated' with increasing time pressure (Vostal 2016), increasing the volume and speed of work that academics are expected to complete. The creative dimensions of academic work (the need to produce new and meaningful ideas, or to provide up to date and relevant teaching), along with the classic problem of the indeterminacy of labour, make straightforward forms of managerial control difficult. Instead of the dictatorial and electronically enabled forms of control and surveillance found, for example, in call centres (Woodcock 2017), there is the pressure of the abstracted metrics discussed previously. Like with other forms of digital and creative labour, there is the need for capital (or its managerial representatives) to 'balance' the 'insatiable need for a stream of innovative ideas with the equally strong imperative to gain control over intellectual property' and workers (Huws 2010, 504). Thus, the work itself is often removed from direct forms of managerial control, with academic workers left to motivate themselves to reach targets on research or teaching. The application of digital technologies 'have fundamentally transformed knowledge production', applying 'not only to how we create, disseminate, and consume knowledge, but also who, in this case, counts as "we"' in universities (Bacevic 2017). In this way, digital technologies have become increasingly bound up with the actual processes of knowledge construction itself, not only changing how this happens but also opening up the processes to a broader range of actors

The 'objects on which that work is performed' is complicated by the differences in the purposeful activities of academic work. The first 'object' is that of published knowledge, the creation of journal articles and books, subjected as they are to detailed metrics and comparison, and enclosed by publishers. The publication of this kind of research has become a key concern for academics in order to achieve particular rankings, although the critique of academia has usually aimed for a broader audience than only other academics in their discipline - or just the editor and peer-reviewers of a journal. As Bacevic (2017) points out, from the 'petitions and pamphlets in the Dreyfus 
affair' to more contemporary discussion on social media, 'there is no critique without an audience, and digital technologies are essential in how we imagine them.' The public sphere - mediated in various ways by different technologies - is a terrain of debate that academics can intervene in, successfully or otherwise. Social media, in this vein, becomes one of the 'main vehicles for dissemination' of critique (Bacevic 2017). For example, Hall (2016) poses the question (in the context of rankings faced by many precarious workers) about whether 'in the future, are academics going to have to manage their reputations too?' then follows it up with: 'are we going to have to put a lot of work into performing sociality with our colleagues, students, peers, and friends on Facebook, Twitter, and Academia.edu to ensure that we maintain a good reputation score?' However, the need to actively maintain and effectively utilise social media (Carrigan 2016) is already a major concern for precarious academics.

In the context of teaching, the relationship between students and teachers is increasingly being mediated by digital technologies. The most obvious example of this is the ubiquity of email communication. Teachers in university are expected to be constantly available by email, with the smartphone notification becoming a near-constant reminder of the pressures of academic work. Teaching materials are made available on virtual learning environments, with the expectation of additional resources. While this is a good way to increase the accessibility of materials, it is being furthered with electronic lecture capture. The use of technology to extend the learning experience, particularly for those with access issues or different learning requirements, is potentially positive, however the capture of lectures creates other tensions. Anecdotally, lecture attendance falls when the lecture is available for replay later, missing out on the importance of contact between lecturer and students - something that is already limited in the contemporary university. Additionally, the record of 'e-learning and of distance education technologies [...] have cost cutting (above those associated with the labor force) as their primary objective', seen with the attempts by the University of Phoenix which is premised on the complete technological substitution of the class experience (Roggero 2011, 115). Thus, the suggestion of lecture capture also comes with the risk of academic labour being expelled from the teaching process. These elements form part of the broader tendency that is 'rapidly drawing the halls of academe into the age of automation' as outlined previously by David Noble (1998).

The third key change to the labour process relates to the 'instruments of that work.' The historical image of the academic working in dusty offices or libraries is increasingly giving way to that of a person typing away on a laptop, whether at home, an office (possibly shared), or a coffee shop with wifi. These shifts are also related to teaching. For example, when Bourdieu $(2008,175)$ discussed the 'whole series of techniques' that are 'tacitly required by all teaching', he listed the: use of dictionaries and abbreviations, rhetoric of communication, establishment of files, creation of an index, use of records and data banks, preparation of a manuscript, documentary research, use of computerised instruments, interpretation of tables and graphs, etc.' It would be easy to imagine a whole range of new digitally enabled techniques in the modern university: online searching, navigating proprietary journal databases to find access to articles, effective use of social media, maintaining online resources, and so on.

One of the interesting dynamics that this introduces, as opposed to the analogue resources of the physical library, is a physical decoupling of the instruments of academic work from a geography of the university. In this sense, the university becomes more like a platform - allowing access to institutional subscriptions, email accounts, and other online resources, that do not require a worker to physically be present within 
the university itself. Hall (2016) imagines a near dystopian future that can take advantage of this transformation of the university, in which academic workers 'have little choice but to sell their cheap and easy-to-access courses to whoever is prepared to pay for them in the "alternative" sharing economy education market created by platform capitalism.' The relative freedom of being able to use digital tools to engage with teaching, research, and administration to engage with the university from wherever workers choose also creates the possibility of greater precarisation and outsourcing via a platform mode of organisation. The changes that the digitalisation of the academic labour process creates are summarised in the table below.

\begin{tabular}{|l|l|l|}
\hline \multicolumn{1}{|c|}{ The Labour Process } & \multicolumn{1}{|c|}{ Academic work } & Impact of Digitalisation \\
\hline $\begin{array}{l}\text { The 'purposeful activity, } \\
\text { that is work itself' }\end{array}$ & $\begin{array}{l}\text { Research, teaching, } \\
\text { Administration }\end{array}$ & $\begin{array}{l}\text { Acceleration of activities, } \\
\text { linked to managerial strat- } \\
\text { egies of control }\end{array}$ \\
\hline $\begin{array}{l}\text { The 'objects on which that } \\
\text { work is performed' }\end{array}$ & $\begin{array}{l}\text { Research outputs (journal } \\
\text { articles, books, publicity), } \\
\text { teaching materials }\end{array}$ & $\begin{array}{l}\text { Online media outputs and } \\
\text { new metrics for research } \\
\text { success. Email, online } \\
\text { materials and lecture cap- } \\
\text { ture for teaching. New } \\
\text { methods of control. }\end{array}$ \\
\hline $\begin{array}{l}\text { The 'instruments of that } \\
\text { work' }\end{array}$ & $\begin{array}{l}\text { Tools for researching, } \\
\text { writing, and teaching }\end{array}$ & $\begin{array}{l}\text { New skill requirements } \\
\text { and the university becom- } \\
\text { ing more like a platform. }\end{array}$ \\
\hline
\end{tabular}

Table 1: The digitalisation of the academic labour process

These three component points are key to the analysis here. However, across each of these dimensions is another factor that is greatly transforming the labour process of academics: precarity. As Montoya and Pérez (2016) note, 'in conversation, scholars cannot help but constantly raise the subject of their increasingly precarious working conditions and the anxieties that derive from them.' Precarity has become a prominent feature of working in a UK university - or universities if multiple part time contracts are entered into simultaneously. For example, Weber $(1946,129)$ wrote about how an academic career in Germany was 'generally based on plutocratic premises' and that 'it is extremely risky for a young scholar without private means to expose himself to the conditions of an academic career. He must be able to survive at least for a number of years without knowing whether he has any prospects of obtaining a position that will enable him to support himself.' The contemporary precarity in academia is 'deepened and exacerbated by other processes attuned with neoliberal logics' (Montoya and Pérez 2016) that have started with the introduction of detailed metrics, greatly improved and accelerated in a digital context. 


\section{Towards an Alternative}

The previous sections have sketched out the role of the university and knowledge under capitalism, examined the particular UK context, and analysed the changes of the academic labour process through digitalisation. However, what is missing so far is the resistance of workers in the university to these changes, both for academics and the other forms of work upon which the university relies (Woodcock 2014a). However, since the disastrous pensions dispute, the University and College Union (UCU) has been particularly absent. There have been a number of campaigns by casualised academic workers, for example at Goldsmiths ${ }^{1}$ and SOAS ${ }^{2}$, but nothing has been organised in a sustained way on a national level. There are lessons that can be learnt from the Operaismo (or Italian Workerism) to guide analysis of the contemporary problems of academic work, resistance, and what kinds of organisation could be effective. Although this article has focused on tracing the changes from-above (as it were) that are transforming universities, this only provides a partial account of how knowledge is being produced. The core of this kind of analysis begins, as Tronti $(1971,89)$ argued, by 'invert[ing] the problem', to 'change direction, and start from the beginning - and the beginning is working-class struggle.' The problem with this approach in the university is that there is not a wide range of open struggles from which this analysis can begin.

An important contribution of Operaismo is the idea of class composition, which is particularly useful here. This considers the analysis of work along two dimensions. The first is the technical composition; including: the labour process, the application of technology, management strategies, and the conditions of the reproduction of labour power. The second, and related although not determined by the former, is the political composition: the practices, traditions, and forms of struggle, something that is itself continually in a process of re-composition. The stringent pressures of rankings and metrics combine to create conditions within the technical composition that lead to what Roggero $(2011,23)$ has called 'blockages' within the struggles of precarious academic workers. As he has argued 'to use operaismo's classic terms, the political composition of the class is crushed within the sociological mold of its technical composition' (Ibid.).

The result of the 'blockages' is that sustained struggle within the university has become limited, giving the impression that not much is currently happening on the terrain of workplace struggle. One important limitation is that trade union demand remain at the level of wages or pensions, not taking on question of control. By failing to contest control over the organisation of work by management, workers themselves are left in a difficult structural position. The drastic shift in the frontier of control in the workplace means that it no longer appears as something that can even be contested, leaving significant power in the hands of management. This represents the further 'subsumption' of capital over labour within the university (Szadkowski 2016b, 10). The push for intensifying work through metrics and digital technologies, particularly through what Dardot and Laval $(2013,261)$ have termed 'entrepreneurial self-government' limits the scope further. The precariousness of academic work also contains an element of 'autoprecarization', and Montoya and Pérez (2016) warn that academics need to consider 'our contribution to dragging others into precarity (as a condition of vulnerability not restricted to labour) within and beyond the walls of universities'.

\footnotetext{
${ }^{1}$ See: http://www.newleftproject.org/index.php/site/article comments/the postgraduate workers association

2 See: http://fractionalsforfairplay.webs.com
} 
In previous years, particularly during the wave of student protests in 2010, questions around the role of the university and its future were vigorously debated. Following the decline of that movement, along with the failure of a number of trade union campaigns, the horizons of struggle in the university have significantly narrowed. However, the university remains an important site for research, particularly as it can combine both the objects and subjects of research. The combination of education and technology 'offers mechanisms through which one might challenge, resist and push-back against the marketization of public education, indentured study and the hidden curriculum that asserts the primacy of value-for-money, impact metrics, productivity and efficiency' (Hall 2015, 121).

An important way forward here is the notion over 'conricera' that Roggero (2011, 136) discusses as a key innovation of Operaismo. This idea of co-research builds on the traditions of workers' inquiry, starting with Marx's (1880) call for a survey of working conditions. This inspired a critical Marxist approach that sought to combine the construction of knowledge about workplaces with new experiments in organising (Woodcock, 2014b). It involves the blurring of the traditional barriers between researcher and subject, seeking to go beyond the organisational and disciplinary (in both senses of the term) bounds of the university. Roggero $(2011,141)$ argues that when:

\begin{abstract}
Knowledge becomes the central resource and means of production, the intellectual function is completely absorbed within the new class composition, and in cognitive labor are traced the coordinates and cooperation and exploitation, conricerca can become a directly constituent practice. Reconfiguring its location from spatial continuity towards the preeminence of the temporal, conricerca is potentially an instrument for the exercise of the autonomy of living labor and the method for the construction of the institutions of the common.
\end{abstract}

This is an important reminder for contemporary academic work. The university is a site in which research tools are developed, research is undertaken, and new analysis proposed. However, too often these are not applied to the academic work within the boundaries of the university. Co-research provides an important way to refresh the analysis of academic work, not only to propose new ideas, but also to experiment with new forms of organisation that can go beyond the blockages of the neoliberal university. Rather than watching the new digital tools being used to further the precariousness and alienation of academic work, they can be adapted and modified to fit a project for a very different kind of university.

In practice, this means re-thinking what kinds of research should be undertaken and how it can be carried out. If the university is becoming increasingly digitalised and precarious, there are many other examples of work beyond the campus that are being transformed in this way too. Through initiating collaborative research projects (forms of co-research) with other groups of workers, the existing methods and digital tools can be repurposed for projects that not only seek to generate knowledge about these conditions, but also aim to change them. In particular, the so-called gig-economy has become a testing ground for both new managerial techniques and forms of workplace struggle. By engaging in critical projects in these areas research can play a role in supporting other workers, but within this reflexive process the university too can begin to be changed. 


\section{References}

Bacevic, Jana. 2017. @Grand Hotel Abyss: Digital University and the Future of Critique. Discover Society, January 3. Accessed 22 January 2018. http://discoversociety.org/2017/01/03/grand-hotel-abyss-digital-university-and-the-future-of-critique

Bailey, Richard. 2013. Exploring the Engagement of Lecturers with Learning and Teaching Agendas Through a Focus on Their Beliefs About, and Experience with, Student Support. Studies in Higher Education 38 (1): 143-155.

Bain, Peter, Aileen Watson, Gareth Mulvey, Phil Taylor and Gregor Gall. 2002. Taylorism, Targets and the Pursuit of Quantity and Quality by Call Centre Management. New Technology, Work and Employment 17 (3): 170-185.

Beer, David. 2016. Metrics Power. Basingstoke: Palgrave MacMillan.

Beverungen, Armin, Steffan Böhm and Chris Land. 2012. Poverty of Journal Publishing. Organization 19 (6): 929-938.

Bourdieu, Pierre. 2008. Political Interventions: Social Science and Political Action. London: Verso.

Braverman, Harry. 1999. Labor and Monopoly Capitalism: The Degradation of Work in the Twentieth Century. London: Monthly Review.

Burrows, Roger. 2012. Living with the H-Index? Metric Assemblages in the Contemporary Academy. The Sociological Review 60 (2): 355-372.

Carrigan, Mark 2016. Social Media for Academics. London: Sage.

Castells, Manuel. 2000. The Rise of the Network Society. Oxford: Blackwell.

Collini, Stefan. 2012. What Are Universities For? London: Penguin Books.

Cooke, Morris Llewellyn. 1910. Academic and Industrial Efficiency. A Report to the Carnegie Foundation for the Advancement of Teaching. New York.

Dardot, Pierre and Christian Laval. 2013. The New Way of the World: On Neo-Liberal Society. London: Verso.

Dyer-Witheford, Nick. 2010. Digital Labour, Species-Becoming and the Global Worker. ephemera: theory \& politics in organization 10 (3/4): 484-503.

Fatsis, Lambros. 2016. The New Rules of Sociological Labour. The Sociological Review Blog, September 19. Accessed 22 January 2018. https://www.thesociologicalreview.com/blog/the-new-rules-of-sociological-labour.html

Fernie, Sue and David Metcalf. 1997. (Not) Hanging on the Telephone: Payment Systems in the New Sweatshops. London: Centre for Economic Performance at the London School of Economics and Political Science.

Frey, Carl Benedikt and Michael A. Osborne. 2013. The Future of Employment: How Susceptible are Jobs to Computerisation. Accessed 27 July, 2017. http://www.oxfordmartin.ox.ac.uk/downloads/academic/The Future of Employment.pdf

Furedi, Frank and Rebecca Attwood. 2012. Satisfaction and Its Discontents. Times Higher Education, March 8. Accessed 22 January 2018. http://www.timeshighereducation.co.uk/419238.article

Hall, Gary. 2016. The Uberfication of the University. Minneapolis: University of Minnesota Press.

Hall, Richard. 2015. The Implications of Autonomist Marxism for Research and Practice in Education and Technology. Learning, Media and Technology 40 (1): 106-122.

Handy, Charles. 1984. The Future of Work: A Guide to a Changing Society. Oxford: Blackwell.

Harvey, Lee. 2008. Jumping Through Hoops on a White Elephant: A Survey Signifying Nothing. Times Higher Education, June 12. Accessed 22 January 2018. http://www.timeshighereducation.co.uk/402335.article

Harvey, Lee. 2003. Scrap That Student Survey Now. Times Higher Education, December 12. Accessed 22 January 2018. http://www.timeshighereducation.co.uk/185492.article 
Huws, Ursula. 2010. Expression and eExpropriation: The Dialectics of Autonomy and Control in Creative Labour. ephemera: theory \& politics in organization 10 (3/4): 504-521.

Huws, Ursula. 2001. The Making of a Cybertariat? Virtual Work in a Real World. Socialist Register 37: 1-23.

Jessop, Bob. 2017. Varieties of Academic Capitalism and Entrepreneurial Universities. Higher Education. 73: 853-870.

Marx, Karl. 1880. A Workers' Inquiry. Accessed July 27, 2017. https://www.marxists.org/archive/marx/works/1880/04/20.htm

Marx, Karl. 1976/1857. Grundrisse. London: Penguin.

Marx, Karl. 1990/1867. Capital, Volume 1: A Critique of Political Economy. London: Penguin. Marx, Karl. 1991/1894. Capital, Volume 3: A Critique of Political Economy. London: Penguin.

McGettigan, Andrew. 2013. The Great University Gamble: Money, Markets and the Future of Higher Education. London: Pluto.

Montoya, Ainhoa and Marta Pérez. 2016. Unravelling Academic Precarity \#UniversityCrisis. Allegra Lab, December 8. Accessed 22 January 2018. http://allegralaboratory. net/unravelling-academic-precarity-universitycrisis

Morgan, Marcus and Patrick Baert. 2015. Conflict in the Academy: A Study in the Sociology of Intellectuals. London: Palgrave Macmillan.

Noble, David. 1998. Digital Diploma Mills: The Automation of Higher Education. First Monday 3 (1). Accessed July 27, 2017. http://journals.uic.edu/ojs/index.php/fm/article/view/569/490

Nonaka, Ikujiro. 1998. The Knowledge-Creating Company. Harvard Business Review on Knowledge Management. Boston: Harvard Business School Press.

Pasquinelli, Matteo. 2015. Italian Operaismo and the Information Machine. Theory, Culture \& Society 32 (3): 49-68.

Pasquinelli, Matteo. 2011. Machinic Capitalism and Network Surplus Value: Notes on the Political Economy of the Turing Machine. Accessed July 27, 2017. http://ge.tt/40VrLRa/v/0

Pasquinelli, Matteo. 2009. Google's PageRank Algorithm: A Diagram of Cognitive Capitalism and the Rentier of the Common Intellect. In Deep Search: The Politics of Search Beyond Google, edited by Konrad Becker and Felix Stalder, 152-163. London: Transaction Publishers.

Roggero, Gigi. 2011. The Production of Living Knowledge: The Crisis of the University and the Transformation of Labor in Europe and North America. Philadelphia: Temple University Press.

Szadkowski, Krystian. 2016a. Socially Necessary Impact/Time: Notes on the Acceleration of Academic Labor, Metrics and the Transnational Association of Capitals. Teorie vědy (Theory of Science) 38 (1): 53-85.

Szadkowski, Krystian. 2016b. Towards an Orthodox Marxian Reading of Subsumption(s) of Academic Labour under Capital. Workplace 28: 9-29.

Taylor, Frederick Winslow. 1967. The Principles of Scientific Management. New York: Norton.

Tronti, Mario. 1971. Operai e Capitale. Turin: Einaudi.

Tronti, Mario. 1965. The Strategy of the Refusal, Operai e Capitale ("Workers and Capital"). Accessed July 27, 2017. https://libcom.org/book/export/html/439

Virno, Paolo. 2001. General Intellect. Translated by Arianna Bove. Accessed July 27, 2017. http://www.generation-online.org/p/fpvirno10.htm

Vostal, Filip. 2016. Accelerating Academia: The Changing Structure of Academic Time. Basingstoke: Palgrave Macmillan.

Weber, Max. 1946. Science as Vocation. In Max Weber: Essays in Sociology, edited and translated by Hans H. Gerth and C. Wright Mills. New York: Oxford University Press: 129156.

Winn, Joss. 2014. Writing About Academic Labour. Workplace: A Journal for Academic Labour 25: 1-15. 
Woodcock, Jamie. 2017. Working the Phones: Control and Resistance in Call Centres. London: Pluto.

Woodcock, Jamie. 2014a. Precarious Work in London: New Forms of Organisation and the City. City: analysis of urban trends, culture, theory, policy, action 18 (6): 776-788.

Woodcock, Jamie. 2014b. The Workers' Inquiry from Trotskyism to Operaismo: A Political Methodology for Investigating the Workplace. ephemera: theory \& politics in organization 14 (3): 493-513.

Wright, Steve. 2016. Working with Information: Some Initial Enquiries. In Class and Librarianship: Essays at the Intersection of Information, Labor and Capital, edited by Erik Estep and Nathaniel Enright, 73-102. Sacramento: Library Juice Press.

\section{About the Author}

\section{Jamie Woodcock}

Jamie Woodcock is a fellow at the LSE and author of Working The Phones. His current research focuses on digital labour, the sociology of work, the gig economy, resistance, and videogames. He has previously worked as a postdoc on a research project about videogames, as well as another on the crowdsourcing of citizen science. Jamie completed his PhD in sociology at Goldsmiths, University of London and has held positions at Goldsmiths, University of Leeds, University of Manchester, Queen Mary, NYU London, and Cass Business School. 


\title{
Academic/Digital Work: ICTs, Knowledge Capital, and the Question of Educational Quality
}

\author{
Jan Fernback
}

\author{
Temple University, Philadelphia, United States, fernback@temple.edu
}

\begin{abstract}
The ideology of the information society has transformed the performance of academic duties within higher education through the permeation of information and communication technologies (ICTs) into all aspects of the university. These technologies provide a common ground upon which teaching, research, and administration fuse; but how have such arrangements affected the quality of academic work? This ideology functions through values, hierarchies, rewards and punishments, and surveillance that influence routine work. Using a critical orientation, this paper examines the transformation of the quality of the intellectual products and work processes of higher education in a North American context. It examines how the educational technology industry fosters a type of control over academic workers, inhibiting the individual labourer's pursuit of educational quality. Grounded in Foucault's concept of "disciplinary power" and in Freire's notions of critical consciousness, it suggests a community-centred approach toward building knowledge capital in higher education.
\end{abstract}

Keywords: ICTs, Higher Education, Academic Work

\section{Introduction}

The academic enterprise is undergoing a transformation - from open access journals to distance learning collaboratives to course management technologies - brought about by information and communication technologies (ICTs) and the ideology of the information society. This ideology proclaims a set of technologically-centric values epitomizing the power of capitalist logic to commodify all aspects of cultural and economic existence. It has its roots in information infrastructure investment policies in the Global North ${ }^{1}$ that prioritized technological developments centred on economic productivity rather than the public good. According to the ideology of the information society, market transactions satisfy needs for information and thus, any differences between knowledge, information or data are subsumed into "information" as a commodity. This ideology connects ICTs with the commodification of information and marketization, affecting institutional governance and culture, and informing the performance of academic duties within higher education. The process of scholarly review, the content of scholarly publication, and the educational enterprise have been transformed in light of new institutional relationships, global information flows, and capital structures enabled by new communication technologies. These new technologies provide a common and necessary ground upon which teaching, research, and administration all coalesce; but how have these new arrangements impacted the quality of each separate venture? How is educational quality shaped when the emphasis on information capital (as material goods to be leveraged in the marketplace) rather than knowledge "capital" (human experience, wisdom, and individual talent in

${ }^{1}$ For example, the National Information Infrastructure (NII) in the U.S. and the European In- 
the Freirean (1985) sense defines the contemporary higher educational mission? What are the implications of such arrangements for academic workers? Using a critical orientation, this paper examines the transformation of the quality of the intellectual products and work processes of higher education in a North American context: academic scholarship, instructional activities, and administrative arrangements. By examining the ways that ICTs have transformed the actual work carried out by academics, it suggests a grounded, community-centred approach to addressing issues of knowledge capital in contemporary higher educational environments. Of particular use is Foucault's concept of "disciplinary power" in which institutional arrangements dictate control through the normalization of a host of procedures with a minimum exercise of force (Foucault 1977). In educational institutions, social arrangements regarding the exchange of knowledge, information, work, and evaluation are nurtured through values, established hierarchies, rewards and punishments, and surveillance. These social arrangements in the academy are enabled by ICTs. Gradually, the performance of academic labour (defined here as the work product of the university) is not only informed by ICTs but is dependent upon them as they become intrinsic to the operation of higher education. This paper also uses Freire's (1985; 2005/1974) ideas about education as a reproduction of dominant power structures that may be challenged by the valuing of local, experiential knowledge and wisdom as a democratizing force. The argument is that the espousal of ICTs in higher education has created an ideology that exalts information capital in ways that discipline academic workers and de-value knowledge capital and the quality of teaching, research, and administration.

According to Garnham (2002), the ideology of the information society shapes educational policy debates by asserting that ICTs enhance traditional learning modalities. Yet, the reality proves the only enhancements are financial ones to the elites with vested interests in propping up that technocratic ideology. In full embrace of this ideology, course learningware, administrative support software, and online journal submission/review processes are labour-saving ICTs adopted in order to save money over time by ostensibly increasing productivity (Gruner et al. 2015; Garnham 2002). Following Garnham (2002), the ideology of the information society stresses the technologically novel and innovative within the educational sector. This stance is revealed within the parameters of a corporatized university governance system that seeks to exploit ICTs for increased worker productivity and to respond to neoliberal pressures to appear competitive in the "information society" (Jarvis 2001). Such governing practices value information capital (marketized information products) rather than knowledge capital (individually developed learning and wisdom). For example, globally branded courseware and database providers have created what might be considered a hegemonic need among colleges and universities to maintain, for their various constituencies, a basic appearance of capability in the contemporary information environment. They also create a need to maintain contracts with ICT providers and to hire IT workers to troubleshoot courseware or database problems.

The global economy has embraced the ideology of the information society, and the academy apparently cannot be left behind. That hegemonic assumption means that scholarship, teaching, and administration are all transformed, in terms of quality, by the ICT revolution. The educational mission becomes indivisible from the ideology of the information society when ICTs are relied upon in the institutional arrangements, processes, and management of higher education. Within higher education, quality (following Cheng 2016) is not about managerial control, compliance, and bureaucracy. In teaching, research, and administration, quality is a "virtue of professional prac- 
tice" wherein the self-motivation to learn, teach, and work is the objective and noninstrumental pursuit of the excellence worthy of higher education (Cheng 2016, x-xi). Through a critical stance toward the marketization of ICTs, this paper explores how the educational technology industry operates to promote a disciplinary power over academic workers, thus impeding the individual labourer's pursuit of educational quality or Freirean (1985) transformation.

\section{ICTs and the Purpose of the University}

As ICTs became integrated into the higher educational landscape during the late 20th century, utopian and dystopian discourses began characterizing the new environment. Among the critical voices were those wary of the imposition of technologies onto what was assumed to be semi-autonomous ventures in teaching, research, and creative work. Notably, David Noble (1998) outlined the corporate takeover of universities through online education and other "automated" technologies in a regressive movement toward mass production. Others (Hamilton 2016; Jarvis 2001; Robertson 2003) argue that commercial interests are corporatizing the university so that knowledge is commodified, societal and individual interests in higher learning are subjugated, and managerialization increasingly typifies academic values.

These trends are evident in contemporary approaches to scholarship, teaching, and administration. New journals and corporate, transnational scholarly databases offer masses of information about which active scholars must stay informed. Students expect ICTs in the learning environment, but is there a coercive element to the use of these technologies? Do they enhance learning at the expense of validity or wisdom? Administrative ICTs may (or may not) increase organizational efficiencies, but compliance with them is enforced through hierarchical means, including resource allocation or expense reimbursement. What might be the individual and institutional costs for these imperatives?

Traditionally, and ideally for the Global North, the purpose of university education, is to develop, build upon, and transmit reasoned intelligence to future generations and to society at large. This involves helping students to foster critical judgment and analytical aptitude in order to provide education for professional careers, citizenship, and stewardship of human knowledge. For Freire (1985), education is about realizing human potential. There is a purity of purpose - education for the public spirit, according to Bowles and Gintis (2011) - that was not to be sullied by the discourse of free enterprise. The purpose of education shifts with time and space, but capitalist imperatives consign universities to the logic of the public sector rather than the public good (Bowles and Gintis 2011). While the ideology of the information society informs the performance of academic duties within higher education, the performance of academic work itself becomes dependent upon ICTs. This means that work undertaken in the academy - the tangible actions by faculty to produce outcomes (the performance of teaching, research, and service) - is enmeshed with the imperatives of the ideology of the information society. ICTs are now fundamental to the operation of higher education. Foucault's (1977) concept of disciplinary power is useful in understanding how.

\section{Disciplinary Power and Educational ICTs}

Foucault argued that discipline, as a mechanism of power, grew from 17th and 18th century practices which increased the scale of domination enacted on individual bodies to include "a subtle coercion, of obtaining holds upon it at the level of the mechanism itself - movements, gestures, attitudes, rapidity; an infinitesimal power over the 
active body" (Foucault 1977, 137). Discipline expanded the political body through institutional requirements that individual bodies be observed, trained, or otherwise manipulated in order to function in new economic, political, or institutional arrangements (Foucault 1977). The ideology of the information society mandates that capitalist cultures are conserved through technological means which commodify products or services in the market economy. Structures of educational governance which respond to market imperatives therefore require the implementation of educational ICTs to satisfy such imperatives to maintain legitimacy as purveyors of education as a product. Such institutional arrangements discipline faculty through accountability regimes (which Strathern (2000) refers to as "audit culture") that erode autonomy and compound workload. Information technologies are disciplinary in that they are a modality of power enacted on individual bodies for the purposes of expediency. They embody, consistent with Foucault (1977), a rationality giving rise to new norms of worker conduct and professional performance which conjoins faculty to the audit culture. The exercise of power is evident in the surveillance, training, and examination capabilities of information technology, and in the inevitability of its use. The disciplinary power inherent in academic technologies serves to regulate the behaviour of the faculty through the organization of space (the rigid, proscribed architecture of ICT systems) and through behavioural requirements (the mandatory use of universitybranded ICTs).

Disciplinary behaviour is enforced through surveillance mechanisms within the structure of university ICTs, such as accreditation, time logs and "effort reporting" systems. Based on Bentham's conception of the panopticon, a prison architecture allowing all subjects to be monitored by a single, unseen entity, Foucault (1977) notes that prisoners discipline themselves since they are unsure exactly when they are being watched. Supervisors are subject to surveillance from the outside as well (from governments, trustees, donors) and ultimately regulate themselves. Because disciplinary power operates diffusely and opaquely and impacts virtually every aspect of life, it is an efficient form of power that is nearly impossible to defy. Thus, ICTs perform surveillance activities both inside and outside the university; they monitor individuals working at jobs, and they monitor themselves via system logs or selfmonitoring, reporting and analysis (SMART) ${ }^{2}$ technologies.

Here is a link between Foucault's disciplinary power as it applies to academic ICTs and Taylor's theories of labour efficiency. Similar to disciplinary power's reliance on hierarchical observation, surveillance, and normalization, Taylorist principles stressed "scientific management" of the workplace through time/effort measurements, rigid divisions of labour, and hierarchical management techniques (Taylor 1911). Although Taylor's principles were geared toward improved productivity through worker efficiency, control over the workforce became centralized. Taylor describes "soldiering" $(1911,13)$ as a phenomenon whereby workers labour in accordance with the slowest among them - a practice that decreases efficiency while disincentivizing employees to work any harder. According to Braverman (1974), Taylorism deems technology to be a means toward productivity in that it facilitates control of the capitalist labour force by redistributing the sum of worker knowledge toward management. Technology, for Taylor, allowed work to become automated, thus "freeing" workers for unemployment or for non-skilled labour.

2 See: http://www.pcguide.com/ref/hdd/perf/qual/featuresSMART-c.html and "Hard Disk SMART Drives," https://www.pctechquide.com/hard-disks/hard-disk-smart-drives for an explanation of SMART. 
Globally branded courseware is an ICT meant to liberate academics for other types of labour (or to become irrelevant) as courses become automated. These forms of ICTs are valued not as knowledge capital but as time/labour-saving devices. For example, universities provide tutorials on creating video lectures - how to create them and how to make them "engaging." 3 The creation of these engaging video lectures is a form of uncompensated work for the university when the effort expands beyond contractual work obligations. For instance, the Idaho State University workload document ${ }^{4}$ states that faculty receive extra monetary compensation (up to $\$ 1,000$ ) or "workload credit" "if time is available" when teaching courses with "internet-based" components. This policy is an acknowledgment that the effort is not within the normal scope of work but that the faculty member's asset of "time" may not be available for remuneration. In-person lectures cannot be commodified or marketized to the extent that video lectures can (in MOOCs or expensive "great courses" online). This type of profit maximization creates possible additional revenue streams for universities on the back of uncompensated faculty effort. Additionally, Conceição and Lehman (2010) found that faculty overwhelmed by increased institutional demands on time when teaching online resorted to using strategies that I argue diminished the quality of their work, such as grading shortcuts, reliance on test banks, and assigning group work.

In Foucauldian terms, these supplementary video lectures are a normalized type of discipline that measures "the constraint of a conformity that must be achieved" (Foucault 1977, 183) and can be used "in the standardization of industrial processes and products" (184). The university community, in general, does not question the routinized practices emanating from the implementation of these technologies without being perceived as Luddites. The process of routinization and normalization is achieved in part through the claim that ICTs are essential for contemporary work in higher education - and, indeed, for the functioning of the university and its educational mission (see Glen 2008). For example, U.S. universities require the use of ICTs for course enrolment, grade reporting, budgeting, research grant submissions, "effort" reporting, and other functions. Thus, Taylorist notions of efficiency and standardization in service of financialization epitomize disciplinary power over faculty bodies by normalizing the technocratic ideology of the information society - ICTs save time and money, enhance learning, and reassure external constituencies (parents, governing bodies, regulators/accreditors) that universities are technologically savvy and leading-edge.

This ideology is exhibited in the discourses of 1990s higher education reform in the U.S. (Twigg 1996). In a roundtable of higher education policymakers and experts (Ibid.), American higher education was cited for needing to provide more research, training, and teaching - more "productivity" - in the face of dwindling resources. The assumption that instructional software is necessary to increase faculty productivity undergirds the roundtable's claims that this "productivity problem" exists and that it affects educational quality and, more importantly, cost:

Controlling costs means reducing the direct, personal intervention of faculty where possible in the teaching and

\footnotetext{
${ }^{3}$ See, for example: https://www.rit.edu/academicaffairs/tls/course-development/creatingvideos, https://cft.vanderbilt.edu/guides-sub-pages/effective-educational-videos/\#engage, http://teaching.temple.edu/edvice-exchange/2016/03/6-tips-creating-engaging-videolectures-students-will-actually-watch

${ }_{4}^{4}$ See: http://www2.isu.edu/ctech/faculty staff/Workload-Policy.pdf (Page 4)
} 
learning process. [...] One should expect that additional students could be accommodated at lower cost with technology than with traditional teaching methods. [...] In today's academic culture, responsibility for content rests with the faculty. But a shift is occurring in higher education where increasingly the institution is, in a sense, buying content which it can control. (Twigg 1996)

In this roundtable, educational quality is conceptualized in terms of efficiencies of cost and course delivery. A Foucauldian consideration of the faculty member's position in Twigg's scheme indicates a disciplining of the individual through standardization of knowledge production ("content") that the university purchases, further excluding faculty from defining quality within their own teaching. Faculty become purveyors of information capital (in Twigg's scheme by controlling costs through the purchase of content) at the expense of knowledge capital (wherein faculty are coerced into diminishing their pursuit of human knowledge and wisdom).

Similarly, Massy and Zemsky (1995) address the "productivity problem" by imposing onto higher education an economic model of "activity-based costing," which is the parsing of faculty labour into discrete modules in order to improve the ratio of capital cost to labour cost. The modules of faculty labour include classroom instruction, assessment, preparation, and meetings. Such activities can be performed by courseware that grades student work, presents video lectures, and monitors student progress. Unbundling these activities purportedly supports independent learning among students. Here faculty are conceived as an "unproductive" hindrance to student learning and are thus disciplined via ICTs through not only the standardization of faculty work efforts but through the exclusion of faculty creativity and input in the learning process. Massy and Zemsky further assert:

[T]echnology provides more flexibility than traditional teaching methods once one moves beyond minor changes that can be instituted by individual professors. The "career" of a workstation may well be less than five years, whereas that of a professor often exceeds 30 years. Workstations don't get tenure, and delegations are less likely to wait on the provost when particular equipment items are "laid off." The "retraining" of IT equipment, [...] is easier and more predictable than retraining a tenured professor. Within limits, departments will gain a larger zone of flexibility as the capital-labour ratio grows. (1995)

Such "piece labour" echoes Taylorist notions of ceding control to management. Furthermore, faculty are disciplined by homogenizing the faculty body and comparing them to IT equipment. The implication for educational quality is that "workstations" can provide an equally valuable, more "predictable" product at a lower cost. The recommendations put forth by Twigg (1996) and Massy and Zemsky (1995) not only became ingrained into higher education over the past two decades, but they also signalled the exponential rise in the educational technology market. Moreover, the assumption that ICTs will alleviate higher education's "productivity problem" has bur- 
geoned into a larger discourse of markets, knowledge capital, and technological efficiency. This discourse is normalized across higher education in the Global North.

Far from merely influencing the pedagogical mission of the university, the infiltration of ICTs as cost and labour-saving devices has spread to every function of the academy. Course management software, administrative software, and online journal submission/review processes have been adopted to save money with little evidence of effectiveness. Workloads of faculty and administrators have increased as a result of the technological standardization of procedures; what was the domain of support staff has now become the domain of faculty and administrators at the expense of support staff jobs (Gruner et al. 2015). Massy and Zemsky (1995) admit that "faculty might take over duties now performed by staff" (e.g. filling out forms). Hall $(2013,59)$ argues that such surplus academic work is often enacted online, not counting as classroom hours but rather as administrative effort. The normalization of this process eases the surveillance of academic staff, particularly through the use of effortreporting software (the technological version of "time logs"). Part of the innovative potential of Foucault's discipline as a device of power is the classification of individuals into organized categories - types of prisoners, patients, or students - to develop refined subdivisions of space and time (Foucault 1977, 144-149). Massy and Zemsky's (1995) technological schema serves to discipline the faculty member in Foucault's terms: "[S]pread out in a perfectly legible way over the whole series of individual bodies, the work force may be analysed in individual units. At the emergence of large-scale industry, one finds, beneath the division of the production process, the individualizing fragmentation of labour power; the distributions of the disciplinary space often assured both" (Foucault 1977, 145). The assumption that time/labour saving ICTs operate as a means of faculty empowerment is suspect; academic workers often have no choice but to operate within the confines of the arena set up by the technologies themselves. This means that power is not equally distributed; rather, power tends to be concentrated in the hands of the ICT companies and with those entities that support, own, and administer them (e.g., courseware companies). No individual academic can mimic the efficiency, focus, or speed of ICTs. Yet, the costs of labour-saving ICTs have been amplified by an entire ecosystem that has grown around the development, sale, training, and support of such ICTs.

Some academic work activities that are outside the commercial sector, such as reading student work, personal interactions with students and colleagues, peer review, and even administrative meetings, become commercialized when undertaken within the sphere of educational ICTs. In part, this is due to the exercise of disciplinary power through a naturalized conceptualization of these technologies as necessary, useful, and desirable. The idea that the institutional changes enabled by these ICTs serve the interests of individual faculty, administrators and students is ultimately hegemonic, and it is supported by capitalistic discourses accompanying the spread of academic ICTs. These discourses are examined next, within the context of the ideology of the information society and in terms of Freirean notions of quality and Foucauldian notions of disciplinary power.

\section{Discourses of Capital, Technology, and Profit}

In their discussion of "cognitive capitalism" and its significance for educational policy analysis, Peters and Bulut (2011, xxV-xxxiii) claim that knowledge production (amid other forms of immaterial production) is an enmeshment between humans and machines that result in a new form of capitalism and human subjectivity. This new formulation is flexible and "informationalized" in that the reliance on web technologies 
for the growth of global capitalism has heralded digital labour practices and the production of symbolic capital. What this means in the educational sector is that knowledge production becomes centred around distributed, open knowledge and learning structures that are supported by market mechanisms. These include networked knowledge portals and databases "where notions of individual performance have become global networks of labour governance where the traditional divisions between capital and labor are blurred" (Ibid., xxxiii). Based on Peters' and Bulut's claims as well as Foucault's conceptualization of disciplinary power, I argue that the activities, processes, and products of academic work are constrained by, dictated by, and shaped by globally branded software products. As a result, educators' efforts to enact a Freirean (2005) "critical consciousness" - wherein students recognize sociopolitical incongruities and gain knowledge and wisdom from this recognition - suffer.

The corporatization of academic labour is reflected in the discourses of industries and organizations designed to support contemporary higher educational activities involving ICTs. Some examples of these discourses are included here from two major sources. First, EDUCAUSE, a non-profit organization that manages the edu internet domain, has a mission to "advance higher education through the use of information technology." 5 Second, Blackboard, an educational technology company owned by the private equity firm Providence Equity Partners, bills itself as "education's partner in change" with a mission to "to partner with the global education community to enable student and institutional success, by leveraging innovative technologies and services."6

Current policy initiatives for EDUCAUSE focus in part on accountability through university credentialing so that the U.S. might "maintain and advance its status as an economic world leader [...] with technology assuming center stage." In partnership with EDUCAUSE, corporate members serving the higher education IT market can "maximize brand awareness" and earn "value" for companies "through interaction with higher education decision makers [...] and the opportunity to take advantage of an expanding array of marketing options designed to maximize customer reach and visibility."7 These rhetorical exhortations make clear the agency of universities and their political advocates within the flows of global capitalism. Seeking partnership with corporate entities, U.S. higher education is positioned within global markets to compete, in entrepreneurial roles, for profit through the creation of new revenue streams. EDUCAUSE's policy position on intellectual property, for example, is that universities should be empowered to "more easily and more competitively transfer research innovations into the commercial sector." 8 As noted earlier, distance learning initiatives are another area of monetization of the information capital accumulated and stored in the university sector through the use of an array of IT products marketed as time/laboursaving devices while actually increasing academic work since automation suggests the possibility of higher teaching loads. Nowhere in these policy statements is a recognition of educational mission or quality. Who are the "customers" that EDUCAUSE and its partners serve? Is the purpose of a university to provide "research

${ }^{5}$ Educause Mission and Organization. https://www.educause.edu/about/mission-andorganization. Accessed February 26, 2017.

6 "About Blackboard." http://www.blackboard.com/about-us/index.aspx. Accessed March 10, 2017.

${ }^{7}$ https://www.educause.edu/about/corporate-participation/membership. Accessed February 23, 2017.

${ }^{8}$ https://www.educause.edu/focus-areas-and-initiatives/policy-and-security/educausepolicy/issues-and-positions/intellectual-property. Accessed March 25, 2017. 
innovations" for the commercial sector? The centrality of capitalist rhetoric in EDUCAUSE's policy position indicates the Foucauldian normalization of such discourses within higher education. The historical conditions (increasing consumerist, technocratic orientation toward higher education), the power relations (university governance structures that mimic corporate ones), and assumptions (including the sanctioning of Taylorist notions of worker efficiency and technological solutions) have converged to promote the hegemony of the ideology of the information society within higher education.

Blackboard learningware has become part of the higher educational landscape in many universities in North America and Europe. Purchasing Blackboard's products are justified in part by administrative rhetoric of cost containment and value extraction. According to a report, Big Data Has Arrived, produced by Blackboard in conjunction with survey data from The Chronicle of Higher Education (Rubley 2016, 5), administrators report a "substantial" return on investment in learning management systems. But, they claim, "institutional analytics, which seek to improve business practices" have been prioritized over learning analytics, "which seek to improve student success" (Ibid., 7). The Taylorist logic inherent in this report illustrates the technological dictates under which most higher educational institutions function. To appease external constituencies steeped in the discourses of ICTs as eradicators of higher educational bloat, a growing sector of university administrators with monopolies of knowledge manage the systems upon which institutions have become dependent to function pedagogically. Administrative positions conceived around these monopolies of technological knowledge conforming to specific systems have flourished (Tuchman 2009). Entire industries have emerged around courseware application development (add-ons), material sales (webinars, custom training), and staff hires for newly created learningware management positions. One of Blackboard's ${ }^{9}$ webinars highlights what have become hegemonic discourses of educational capitalism:

The Skills to Performance program at Bellevue is a unique model focused on higher order skills that translate to success in industry. The program is designed to drive learning outcomes based on the performance expectations defined by industry while recognizing the varying skill levels of students and architecting paths for them to achieve success. Through a unique public-private partnership with Blackboard, Bellevue has differentiated the learning experience in a way that is intended to attract more students looking for a competitive edge and connects more tightly with the skills that the workforce partners value.

The webinar itself is a product of the drive to monetize various educational products, and simultaneously, the rhetoric of technological capitalism is infused into the webinar's content. The learning goals of the Skills to Performance program are "defined by industry" rather than any goals for individual enrichment or knowledge capital. The program seeks students looking for a "competitive edge" within the strictures of company-defined skill-sets. Such discourses are normalized throughout higher education as a form of disciplinary power. Foucault $(1971,19)$ argued that education "follows

\footnotetext{
${ }_{9}^{9}$ Planning a Workforce Needs Program. http://bit.ly/2srWCDH. Accessed February 23, 2017.
} 
the well-trodden battle-lines of social conflict. Every educational system is a political means of maintaining or of modifying the appropriation of discourse, with the knowledge and the powers it carries with it." By acknowledging the place of the educational institution within a nexus of socio-political discourses of power, it seems that webinars such as these are a response to the market conditions and external pressures to which higher educational administrators are compelled to conform. Finally, the ideology of the information society is upheld through the alterations in knowledge and practices emerging from the normalization of discourse artefacts which previously seemed unrelated - such as ICTs and higher education into market-driven webinars.

Three tendencies, following Cantor and Courant (2003) and McCarthy (2011), characterize the "enterprise ethic" that epitomizes contemporary universities: virtualization (operating the university as an online entity), vocationalization (expecting an industrial return on educational investment), and fiscalization (departmental viability as measured by budgetary means). Together, these tendencies, according to McCarthy (2011) create configurations that erode community, privilege an instrumental rationality underlying discourses of market logic in universities, and favour profit motives that govern university operations (including the investment in time/labour-saving technologies) and influence faculty research agendas toward collaborative efforts with industry. In such configurations, skills and information replace knowledge and wisdom as educational products. Disciplinary power and imperatives toward efficiency that are evident in these technological discourses demonstrate the ascendancy of global market capitalism in universities that may repurpose the overall quality of education, research, and administration itself away from professional excellence and toward managerialization. The emphasis on using ICTs for strategic planning, information acquisition, and market-friendly assessment (what Freire (1985) warns against) results in the de-emphasis on curricula that cultivate the public good - humanistic inquiry, philosophy, civic engagement, critical inquiry - in favour of vocational education. Content management is emphasized through bureaucratic requirements that don't serve the ideal, democratic purposes of the university. According to Cheng (2016), the prominence of bureaucratic, managerial ideas about "quality" in higher education minimize the true concept of quality as a "virtue of professional practice" (Ibid., $x$ ) that advances academics' values and commitment to excellence in teaching, research, and administration.

The use of ICTs in service of capitalistic rationality means that more work effort is offloaded onto faculty. Administrative services once performed by office managers are now performed by the faculty labour force, aided by all manner of software products designed to create "efficiencies" in expense reimbursement, budget management, travel arrangement, time/effort logs, scheduling, grant application submission, and ancillary course preparation (e.g., interaction with library personnel or "recycling" materials in courseware applications). The logic of such processes and standards goes unchallenged. For Hall $(2014,828)$, the technological, capitalistic orthodoxy dominating higher education means that "the productivity of the academic can be measured against her peers through the socially-necessary labour time that determines what her productivity should be" so that collaborative efforts within the academy become discouraged in favour of competition dictated by marketization. According to Cantor and Courant $(2003,6)$, "excessive concentration on profitability and businesslike behavior may lead to the underproduction of the public goods that make [universities] different from and more than a collection of smart folks each doing his or her own thing." As a result, they argue that universities forget to create a diverse 
campus community, preserve and rely upon past wisdom, sustain campus cultural groups (museums, gardens), and encourage interdisciplinarity and non-profitable endeavours. These arguments ground my claims that the ideology of the information society may be critically challenged by community-centred academic work strategies that value knowledge capital.

The ideology of the information society has created capitalist discourses of educational technology that devalue quality in the face of Taylorist efficiencies and Foucauldian surveillance and discipline. The academy is a community which is fragmented by the pursuit of information capital in accordance with the ideology of the information society, and the forces of global capitalism have prioritized discourses about the value of technical and scientific rationality. The language of learning and teaching has changed to resemble the language of business. "Content management" supplants well-theorized and communicated scholarship. The wisdom of past experience, critical ability, and context are underplayed. The mechanisms of Foucault's disciplinary power succeed in making these realities seem normal. But more than 20 years beyond the predictions of Massy and Zemsky (1995), machine grading is still suspect, and the analytical writing portion of the GRE exams is scored by human labour. ${ }^{10}$

Foucault's explication of disciplinary power and normalization of routine practices shows that the technologies of higher education's "audit culture" (Strathern 2000) are vehicles for a type of rationality that sanctions governance based on a subjectivity of individuals who have no choice but to become "auditable." Although Foucault is sometimes criticized for a lack of solutions in praxis and the belief that educational institutions merely reinforce structures of power and dominance, his understanding of disciplinary power provides a starting point, with Freire, toward some concrete strategies of resistance among academic workers. According to Foucault (1972/1980, 133), the role of the intellectual is to act within the community to produce change - to use ideas to spur action - thus "detaching the power of truth from the forms of hegemony, social, economic and cultural, within which it operates". Freire's (1985) critique of education stems from the hierarchical and authoritarian characteristics of schooling that both learners and teachers can resist through "critical consciousness" (Freire 2005/1974). This process liberates them from oppression through community discourses of reflection on lived experiences. Foucault's diagnoses of power arrangements can combine with Freire's mission of critical consciousness to support community-centred resistance to the power relations manifested in higher education's embrace of the ideology of the information society.

\section{Responses to the Inevitability of ICTs in Higher Education}

Responses to the technological challenges to higher education can focus on building knowledge capital with the aid of existing ICT-centred arrangements. This paper suggests models for reconstituting academic ventures in ways that acknowledge the naturalized assumptions regarding the necessity of ICTs while simultaneously pursuing knowledge capital. We have seen how the discursive practices surrounding ICTs in higher education construct a milieu of knowledge/power that has become hegemonic. However, recalling that Foucault's concept of disciplinary power theorizes its enactment over docile bodies, the following models suggest a type of control over one's body as an academic worker. These models are offered as ways to assert freedom within an oppressive configuration of mandated technologies. Within aca-

\footnotetext{
${ }^{10}$ See: http://www.ets.org/gre/institutions/scores/how
} 
demic communities, new practices can emerge that emphasize quality as a "virtue of professional practice" (Cheng 2016) by using ICTs strategically and intelligently rather than conveniently. They include:

1. creating more open (visible) peer review systems that are communally based;

2. building collaborative teaching environments;

3. producing knowledge bases as a way of integrating teaching, scholarship, and administrative responsibilities.

These models are a means to provide academic workers, primarily full-time faculty, a measure of control within the scope of the ideology of the information society through community-based resistance. For Freire, resistance starts when faculty and students work together toward critical consciousness. He recognized power as a form of domination, silencing people through a dynamic of institutional power, ideology, and technology that demands critical consciousness for self-emancipation (Freire 1985). For Foucault $(2003,6)$, the power structures inherent in the educational system can be resisted through a critique at the local level. Foucault argues that institutional power is enacted in every interaction and can thus be challenged through interventions (Foucault 1997) of the type Freire advocates. He argues for the possibility of resistance, claiming "The idea that power is a system of domination that controls everything and leaves no room for freedom cannot be attributed to me" (Ibid., 293). In educational settings, resistance includes "ēthos, practices of the self and of freedom" (Ibid., 299). Ideas of resistance espoused by Freire and Foucault combine to create a framework for the models below.

\subsection{Community-Based Scholarly Peer Review}

Scholarly texts are produced and consumed by disciplinary communities, and ICTs are used to oversee submission and review and to control access to the products of scholarship. To take advantage of the repositories of knowledge within disciplines, scholarly peer review could use ICTs to add a new component to the traditional use of two or three anonymous reviews. This model would involve the embargoed draft article being posted to a communal review web site, organized by journal editors, for a limited time period during which pre-approved, anonymous "reviewers" would comment on the draft and the author could weigh in with responses. The burden on individual reviewers would be lessened by the efforts of the community, and the community gains a preview of new scholarship. Scholars would appropriate the technologies to emphasize knowledge capital, the scholarly exchange of ideas, and the progressive enrichment of documents. This process could occur on cooperative platforms designed outside the architecture of existing commercial ICTs in order to put the communal ethos of scholarly collaboration above corporate control of knowledge production. Digital platforms for communities of interest/practice can enable worker ownership, collective knowledge production, and democratic governance. ${ }^{11}$

Community-based peer review as a form of document enhancement allows for the discussion of ideas within the community as a social practice. This form of review permits a rich context for the document arising from greater understanding of relationships between disciplinary community structures and attendant intellectual products. The gradual refinement of the draft article becomes useful for knowledge capital

\footnotetext{
${ }^{11}$ For an explanation of platform cooperativism, see: http://platformcoop.net/about\#
} 
over the long term since it promotes the wisdom of communal knowledge building over the informationalization of scholarly products.

\subsection{Collaborative Teaching Environments}

A similar model can be developed for teaching in which ICTs are used to develop communal knowledge bases set up at individual universities for the faculty community to talk across and within disciplines about pedagogical strategies, theories, ideas, assessments, and curricula. Components can include knowledge banks enabled by courseware; virtual meetings at designated times within or external to the courseware; FAQs that are disciplinary in nature; and face-to-face meetings. The rewards of this arrangement are: intellectual exchange within a disciplinary community; new/multiple perspectives from interdisciplinary collaboration and conversation; an emphasis on knowledge capital; and potential time savings from not having to "reinvent the wheel" with new course preparations or testing new pedagogical strategies. Freire (1985) argues that pedagogy can challenge the hegemony of naturalized assumptions about the world through communities of practice that seek social change. For Freire, knowledge itself is a social process leading to transformative action, so knowledge bases can be a form of resistance through the above-mentioned rewards. In an educational environment where ICTs have become ingrained into all aspects of the academic venture, faculty can attempt to use those technologies to enact Freire's ethos in transformative ways.

\subsection{Community-Resourced Administration}

Economic conditions and regulatory oversight in universities have resulted in staff cutbacks that have created extra labour for faculty who lack the expertise and proficiency that staff trained in myriad technologies had developed (Gruner 2015). For faculty, this can mean incurring "considerable mental overhead in task-switching" (lbid., 4). But there are possibilities for communal knowledge bases to alleviate some of the administrative burden. In the absence of larger institutional change, groups of faculty and administrators can work collectively to develop repositories of instructions, examples, and shortcuts that empower the community to abate some of the most frustrating, alienating aspects of administrative requirements. As a means of resistance to the disciplinary power exerted within the sphere of institutional ICTs, Hall $(2013,73)$ suggests that academic labourers work toward "developing collective forms of work or doing that enables the development of discretionary power and autonomy beyond the rate of profit [...] to overcome the mechanisms that co-opt how that labour inside capitalism overcomes all of human sociability, to the point where all activity appears to be determined by economic growth." Knowledge bases are a form of collective knowledge capital that can offset the overburdening of academic labour at the expense of educational quality. Workload burdens on faculty are well documented (Ginsberg 2011; Conceição and Lehman 2010), and university governance structures add to that burden, but communal knowledge bases address Hall's (2013) invitation to faculty to work collectively toward a measure of autonomy.

These models are aimed at counteracting, within the boundaries of the possible, the corporatization and informationalization of the university at the expense of academic workers and students who are disciplined as docile bodies within an environment of global capitalist accumulation. Discord arises when compliance with institutional mandates to use specific ICTs interferes with the academic mission, and technological competency requirements siphon time from teaching and scholarly/creative activity. The worth of academic work shifts when capitalistic discourses, Taylorist 
principles, and Foucauldian discipline create new literacies of productivity, new modes of surveillance, and new politics of control.

\section{Conclusion}

Using a critical lens, this paper used a Foucauldian perspective to examine how ICTs, in service of the ideology of the information society, discipline academic workers, thus interfering with work quality or Freirean (1985) transformation. Tuchman (2009) argues in her examination of the marketization of higher education, that universities have become "auditable" - capable of being measured and disciplined. Such "coercive accountability associated with both an audit society and its culture helps to constitute an accountability regime; a politics of surveillance, control, and market management disguising itself as the value-neutral and scientific administration of individuals and organizations" (Tuchman 2009, 12). The accountability regime fostered by widespread institutional use of ICTs establishes faculty as objects of surveillance rather than as co-communicators. Audit culture (Strathern 2000) reveals a relationship of power between scrutinizer (administrative governance) and observed (faculty working within the configuration of educational ICTs). Because educational ICTs conform to the political systems under which they are instituted (the ideology of the information society) they promote the values of informationalization and marketization. Those values filter through the university culture at large, exerting a disciplinary control over faculty workers. Quality is diminished as a result, as faculty are overburdened by technocratic demands (Gruner et al. 2015) that encourage teaching shortcuts (Conceição and Lehman 2010) or inattention to research or creative agendas (Ginsberg 2011).

Acknowledging that faculty must work within the technological structures instituted by universities - and also acknowledging that some of those structures do enhance academic work - this paper suggests means of resisting the political-ideological realities of domination engendered in such environments. Recalling the ideal purpose of the university to build reasoned intelligence and to realize human potential (Freire 1985), a progressive environment for the advancement of knowledge capital must be prioritized. In part, this means valuing wisdom, thinking, communicating, and acting within the academic community to contest the informationalization of the university. Freire argued that education must consider the political and socio-economic context in which it occurs in order to implement critical consciousness. Within the ideology of the information society, Freire's mission to liberate and empower the politically marginalized must account for technocratic realities and respect community-centred models for resistance of disciplinary power.

Foucault $(2003 ; 1997)$ admonished his readers to consider the manifold qualities of power: that power may be constructive as well as exploitive; that power as well as resistance are everywhere; that resistance is power exercised under different conditions; and that freedom provides terrain for both power and resistance. Although neither Freire nor Foucault offered specific directives for resistance, both sought to problematize links between knowledge and power within institutional contexts. With this grounding, citizens of the academy can investigate ways to use information technologies to enrich non-informationalized and non-marketized scholarly exchange. Academic workers can collectively resist the oppressiveness of ICTs employed by educational institutions and use them to make universities into spaces for socially-useful knowledge and for enlightened politics. Educational ICTs do not have to be impediments to free, open inquiry in the university. They do not have to be impediments to knowledge capital as a public good. 


\section{References}

Bowles, Samuel and Herbert Gintis. 2011. Schooling in Capitalist America: Educational Reform and the Contradictions of Economic Life. Chicago: Haymarket.

Braverman, Harry. 1974. Labor and Monopoly Capital: The Degradation of Work in the Twentieth Century. New York: Monthly Review Press.

Cantor, Nancy and Paul N. Courant. 2003. Scrounging for Resources: Reflections on the Whys and Wherefores of Higher Education Finance. New Directions for Institutional Research 119: 3-12.

Cheng, Ming. 2016. Quality in Higher Education. Rotterdam: Sense Publishers.

Conceição, Simone C.O. and Rosemary M. Lehman. 2010. Faculty Strategies for Balancing Workload When Teaching Online. Presented at the Midwest Research-to-Practice Conference in Adult, Continuing, \& Community Education, Michigan State University, Lansing, Michigan, September 26-28.

Foucault, Michel. 2003. Society Must Be Defended: Lectures at the Collège de France, 19741975. New York: Picador.

Foucault, Michel. 1997. The Ethics of the Concern for Self as a Practice of Freedom. In Ethics: Subjectivity and Truth, edited by Paul Rabinow, 281-301. New York: The New Press.

Foucault, Michel. 1980/1972. Power/Knowledge. New York: Pantheon.

Foucault, Michel. 1977. Discipline and Punish: The Birth of the Prison. New York: Pantheon.

Foucault, Michel. 1971. Orders of Discourse. Social Science Information 10 (2): 7-30.

Freire, Paulo. 2005/1974. Education for Critical Consciousness. London: Continuum.

Freire, Paulo. 1985. The Politics of Education: Culture, Power, and Liberation. South Hadley: Bergin \& Garvey.

Garnham, Nicholas. 2002. 'Information Society' as Theory or Ideology: A Critical Perspective on Technology, Education and Employment in the Information Age. In Digital Academe: The New Media and Institutions of Higher Education and Learning, edited by William $\mathrm{H}$. Dutton and Brian D. Loader, 253-267. London: Routledge.

Ginsberg, Benjamin. 2011. The Fall of the Faculty: The Rise of the All-Administrative University and Why It Matters. New York: Oxford University Press.

Glen, Marie. 2008. The Future of Higher Education: How Technology Will Shape Learning. A report by the Economist Intelligence Unit, sponsored by the New Media Consortium. Accessed June 10, 2017. https://www.nmc.org/pdf/Future-of-Higher-Ed-(NMC).pdf

Gruner, Sol M., David Easley, Eric Giese, Tim Healey, Hening Lin, Michael Lenetsky and Paul McEuen. 2015. Report of the College of Arts and Sciences Committee on Streamlining Research Administration. Accessed April 1, 2017. https://blogs.cornell.edu/deanoffaculty/files/2016/11/Streamlining-Administration$1 \times 4 \mathrm{k} 5 \mathrm{pj} . \mathrm{pdf}$

Hall, Richard. 2014. On the Abolition of Academic Labour: The Relationship between Intellectual Workers and Mass Intellectuality. tripleC: Communication, Capitalism \& Critique 12 (2): 822-837. http://www.triple-c.at/index.php/tripleC/article/view/597

Hall, Richard. 2013. Educational Technology and the Enclosure of Academic Labour inside Public Higher Education. Journal for Critical Education Policy Studies 11 (3): 52-82.

Hamilton, Edward C. 2016. Technology and the Politics of University Reform: The Social Shaping of Online Education. Basingstoke: Palgrave Macmillan.

Hanley, Larry. 2002. Educational Technology and Academic Labor. The Radical Teacher 63: 25-28.

Jarvis, Peter. 2001. Universities and Corporate Universities: The Higher Learning Industry in Global Society. London: Kogan Page.

Massy, William F. and Robert Zemsky. 1995. Using Information Technology to Enhance Academic Productivity. Educomreg, Interuniversity Communications Council, Inc. Accessed March 15, 2017. https://net.educause.edu/ir/library/html/nli0004.html 
McCarthy, Cameron. 2011. Afterword: The Unmaking of Education in the Age of Globalization, Neoliberalism and Information. In Cognitive Capitalism, Education and Digital Labor, edited by Michael A. Peters and Ergin Bulut, 301-321. New York: Peter Lang.

Noble, David. 1998. Digital Diploma Mills: The Automation of Higher Education. First Monday 3 (1). Accessed March 3, 2017. http://www.firstmonday.org/ojs/index.php/fm/article/view/569

Peters, Michael A. and Ergin Bulut. 2011. Introduction. In Cognitive Capitalism, Education and Digital Labor, edited by Michael A. Peters and Ergin Bulut, xxv-xl. New York: Peter Lang.

Robertson, Heather-Jane. 2003. Toward the Theory of Negativity: Teacher Education and Information and Communication Technology. Journal of Teacher Education 54 (4): 280296.

Rubley, Julie Nicklin. 2016. Big Data Has Arrived: Using Technology to Measure Student Performance. Accessed January 14, 2017. http://www.blackboard.com/educationanalytics/resource/chronicle-survey-report.aspx

Strathern, Marilyn. 2000. Audit Cultures: Anthropological Studies in Accountability, Ethics and the Academy. London: Routledge.

Taylor, Frederick Winslow. 1911. The Principles of Scientific Management. New York: Harper and Brothers.

Tuchman, Gaye. 2009. Wannabe U: Inside the Corporate University. Chicago: University of Chicago Press.

Twigg, Carol. 1996. Academic Productivity: The Case for Instructional Software. A Report from the Broadmoor Roundtable, Colorado Springs, Colorado, July 24-25. Accessed February 27,2017 . https://net.educause.edu/ir/library/html/nli0002.html

\section{About the Author}

Jan Fernback

Jan Fernback is Associate Professor of Media Studies in the Klein College of Media and Communication at Temple University. Her current work examines issues of privacy and surveillance online and in mobile technologies, the impact of information/communication technologies on urban revitalization efforts, institutional uses of ICTs, and the meaning of virtual community in contemporary culture. She is the author of Teaching Communication and Media Studies: Pedagogy and Practice, published by Routledge. 


\title{
Manual Labour, Intellectual Labour and Digital (Academic) Labour
}

\section{A Critical Enquiry of the Practice/Theory Debate in the Digital Humanities}

\section{Christophe Magis}

Université Paris 8-Cemti, Paris, France, christophe.magis@univ-paris8.fr, https://cemticritic.eu/christophe-magis

\begin{abstract}
Although it has not been much considered as such, the digital humanities movement (or at least the most theoretically informed parts of it) offers a critique "from within" the recent mutation of the higher education and research systems. This paper offers an analysis, from a Critical Theory perspective, of a key element of this critique: the theory vs. practice debate, which, in the digital humanities, is translated into the famous "hack" vs. "yack" motto, where DHers usually call for the pre-eminence of the former over the latter. I show how this debate aims to criticise the social situation of employment in academia in the digital age and can further be interpreted with the culture industry theoretical concept, as a continuance of the domination of the intellectual labour (i.e. yack in this case) over manual labour (hack). I argue that, pushing this debate to its very dialectical limit, one realises that the two terms are not in opposition anymore: the actual theory as well as the actual practice are below their very critical concepts in the current situation of academic labour. Therefore, I call for a reconfiguration of this debate, aiming at the rediscovering of an actual theory in the academic production, as well as a rediscovering of a praxis, the latter being outside of the scientific realm and rules: it is political.
\end{abstract}

Keywords: Critical Theory, Digital Humanities, Culture Industry, Theory/Praxis, Digital Labour

Acknowledgement: An earlier version of this article has been presented at the "Théorie critique et humanités numériques" conference, held at the University of Liège (Belgium), in November 2016. The author would like to express his gratitude to the participants and organisers of this conference as well as to his colleagues Fabien Granjon and Benoît Lelong at the Université Paris 8, France.

"Theory is already practice. And practice presupposes theory. Today, everything is supposed to be practice and at the same time, there is no concept of practice."

Theodor W. Adorno and Max Horkheimer, Towards a New Manifesto.

The last fifteen years have seen the rise of a new category within the humanities: that of digital humanities (DH) (Schreibman, Siemens and Unsworth 2004). Stemming from previous categories such as humanities computing - which described a new movement of reflexivity about the increasingly prevalent use of computer-based techniques and tools within the humanities - this new formula intended to question the new ways of practicing and producing knowledge in the contemporary social and human sciences and accompanied the creation of new departments, laboratories, conferences, books, 
and so on (Granjon and Magis 2015). ${ }^{1}$ Several writers, such as Richard Grusin (2013), have rightly stated how this proliferation could also be (and has been) used to intensify the marketisation of knowledge in academia (speeding up the movement of dissemination of the information and communication technologies [ICT] within the universities, or giving some new phony appeal to older departments by the magic of renaming them "digital"). Nevertheless, and in spite of the fact that the notion of digital humanities can hardly be seen as forming a coherent and homogeneous epistemological movement (Alvarado 2012; Terras 2011), it can though be assessed that a growing part of the "digital humanists" engage in some critical considerations of the preeminent role that the digital has come to take in the processes of forming, validating and using knowledge in the contemporary societies (Berry 2012; Jones 2014; Svensson 2016) as well as the subsequent mutations of the academic labour's conditions. ${ }^{2}$ Thus, in a systematic analysis of the corpus, Fabien Granjon and I recently pointed out how some theories and practices within the field of digital humanities could be considered as reinterpreting some key features of the critique in social sciences, from the perspective of questioning technology in academia (Granjon and Magis 2016). Even if most DHers (i.e. self-identified practitioners of the digital humanities) usually do not claim it this way - sometimes even using traditional Marxist critique, or critical theories as repellent (Hayles 2012; Pannapacker 2012) - it can however be affirmed that, from their general technology-related framework, a growing part of these approaches (self-)labelled "digital humanities" critically and reflexively analyse the mutations of the educational systems and sectors from within.

In the present article, which stems from this analysis of the DH corpus, I will focus on a specific feature of the digital humanities' reflexion, namely that of the theory vs. practice debate. Analysing the specific features of this debate in the field, and especially the emphasis put on practice (through the experience of "hacking"), I will point out how it can in fact be reflexively related to a critique of division of labour in academia in the digital age, should one consider it seriously (1). Thus, I shall outline a critical reading of the terms of this debate susceptible to bringing new light on their broken dialectical relationship under the current conditions and mutations of the culture industry, considered as an unidimensional drive within academic thought (2). We will thus see how, under these conditions, the "hacking", has become what its very practice aims to criticise (3). Therefore, I will call for a radicalisation of both the concepts of theory and practice in the $\mathrm{DH}$ field and, from that, in the entirety of critical humanities in the digital age. From this perspective, academic labour should aim at an academic concept of theory and a political concept of practice (4).

\section{1. "Hack" vs. "Yack": Towards a (Techno-)Pragmatic Critique of the Traditional Division of Labour in Academia}

One of the most important trends in digital humanities can be grasped through the "hack" vs. "yack" debate. Of course, whether in the DH field or not, and be it from a critical perspective or not, every "reasonable" scholar would easily argue that theory

${ }^{1}$ Even if the instability of the notion makes it difficult to quantify, the $\mathrm{DH}$ field has been quantitatively investigated in a 2011 study produced by the UCL center for Digital Humanities. It revealed the existence of 114 centres for digital humanities at this date, spread out in 24 countries (especially of the North). More figures: http://www.ucl.ac.uk/infostudies/melissa-terras/DigitalHumanities/nfographic.pdf

2 Especially since the "critical" turn in the DH corpus, around 2015 onwards, that has been given much attention by French scholars (see Citton 2015; Bigot, Gruson-Daniel and Valluy 2016). 
and digital praxis "should inform each other" (Schmidt 2011). I shall deal with this "reasonable" rhetoric in the last section of this article, but in the most epistemologically informed developments of the digital humanities the balance between theory and praxis has generally been in favour of the latter. Immersed in a "hacker ethic" (Himanen 2001) or "hacker imagination" (Broca 2016), the digital humanities have called for a pre-eminence of the making (coding, pirating, data-mining) over the theoretical spiel; a call crystallised in the famous motto of the THATCamp conference: "more hack; less yack!" (Murray-John 2011).

In the digital humanities, the programme such a slogan sketches is that of a pragmatic reflexion that must not be limited to the sole risk of a "great divide" between positivist empiricism and idealist theoricism - against which some digital humanists have warned (Fitzpatrick 2011). Rather, the promoted "hack" invites to pay attention to two major facts:

- Firstly, that the digital is a set of practices which computer-based technologies contributed to form. Put otherwise, that the digital does not exist outside of what people do with it, and especially in their professional and academic practices;

- Secondly, that in the whole field of social sciences and humanities research, most digital-related tasks are often assumed by under-considered technical staff or by technically inclined and qualified individuals working outside the realm of the university or at its peripheries.

On the one hand, the recent history of the humanities as well as of social sciences shows how, until the last decade, "the labour-intensive and profoundly human domains of teaching and research have been notoriously absent from the technological makeovers that have characterized the private sector and even government" (Alvarado $2011,47)$. And although "things are different now" (47), this situation has led to specific hierarchies amongst departments, between the traditional scholars and what Milad Doueihi (2011) calls the "accidental digiticians", some colleagues that, being just a little more inclined to use the computational technologies at work, finally had to get more and more specialised as the others left them to deal with the necessary everyday management of mundane technical issues. Indeed, the imagination upon which the traditional figure of the humanities researcher is built is that of a "pure" and solitary spirit (McCarty 2005, 12), necessarily kept away from most of the down-to-earth trivial duties, and so it seems to be a mandatory position amongst distinguished scholars to appear almost completely technically unskilled. And alongside these duties, most of the digital realisations carried out by digital humanists usually simply "do not count" for tenures or promotions (Scheinfeldt 2008; Schreibman, Mandell and Olsen 2011). As Anne Burdick, Johanna Drucker, Peter Lunenfeld, Todd Presner and Jeffrey Schnapp put it in their famous book Digital Humanities: In the History of Institutionalisation of Knowledge Production, "the process of 'how' became separated from the content of "what"' and commitment to the latter "characterized by criticism, hermeneutics, and close reading, almost exclusively undertaken by a single author who works to articulate a highly defined problem in a specific discipline" (Burdick et al. 2012, 76), has become the only seriously recognised academic value.

On the other hand, this "more hack" appeal is also related to the "alternative academics" ("\#alt-ac") movement, which is very active within the field of digital humanities and promotes these professions which "often demand doctoral-level training in the hu- 
manities but generally do not offer tenure-track positions" (Nowviskie 2011, 180). Although, again not really being a formalised and coherent movement within the DH field, the "alt-acs" have come to join and resonate with other struggling movements within international academia. ${ }^{3}$ Therefore, it embraces the latter's main lines of action: critique of the worldwide downsizing of tenure-track faculty positions and, above all, of the disdain with which most precarious researchers are considered in the universities, in terms of recognition of their work, low level of pay, massive delays in payment - all caused by the recurrent use of casual short-term contracts or even zero-hour contracts to employ the majority of the academic working force. ${ }^{4}$ Here again, most complaints reveal how this contractisation has led to a double-class university employment: on the one side, tenured faculties see their teaching hours paid, as well as their teaching preparation and correction times, their research work and their administrative duties (that they try to limit); on the other side, the non-tenured "young" doctors, PhD students and "adjunct professors" are paid on the teaching hour, and must use their "leisure time" to conduct research projects. And, most of the time, they cannot, busy as they are using this "leisure time" to try and find another contract to simply survive, never knowing if they are going to still be part of any university faculty the next semester. ${ }^{5}$ Thus, a despicable class struggle is also starting to exist between the two sides, as most of the former end up being the formal recruiters of the latter, sometimes asking them for help with tasks that are not due in their contracts (especially administrative or technical duties) or to continue working even after a contract has ended. As many newspaper articles that have come to address this issue have revealed, interviewing some of those precarious academics, they most of the time have no real choice to refuse as it would simply lead to the end of any academic career they could hope for. ${ }^{6}$ Consequently, at a time when most of the teaching or researching workers in the universities are not granted a tenured position, and amongst those who do, a hierarchy still exist between the "pure thinkers" and the others whose thinking is seen as flecked

${ }^{3}$ Movements such as the \#NationalAdjunctWalkoutDay in the United States in Feb. 2015, the \#precariousPSA within the Ontario Confederation of University Faculty Association that held conferences on the theme of precariousness within academia, cf. http://ocufa.on.ca/conferences/confronting-precarious-academic-work/, or the Collectif des Travailleur•e•s Précaires de l'Enseignement Supérieur et de la Recherche, in France http://precairesesr.fr/ In the United Kingdom, the University and College Union has organised a lecturer's strike in May 2016 to draw attention on the casual contracts and pay gaps within the university workers, cf. https://www.theguardian.com/education/2016/may/25/uk-university-lecturers-strike-overpay

${ }^{4}$ See for instance https://www.theguardian.com/higher-education-network/2016/may/26/students-your-lecturers-are-on-strike-because-they-are-struggling-to-survive ; https://www.theguardian.com/us-news/2017/sep/28/adjunct-professors-homeless-sex-workacademia-poverty ; http://www.lemonde.fr/idees/article/2016/06/16/la-precarisation-de-l-enseignement-superieur-et-de-la-recherche-nous-asphyxie $4952106 \quad 3232 . \mathrm{html}$; http://www.lemonde.fr/education/article/2014/12/11/nouvelle-obilisation-dans-l-enseignement-superieur-et-la-recherche 4538800 1473685.html and http://www.lemonde.fr/enseignement-superieur/article/2012/11/26/a-I-universite-50000-precaires-bon-marche-etcorveables-a-merci 1795940 1473692.html (the latter in French).

5 "You don't know from one semester to the next whether you're going to be hired for the next semester, and if the courses don't fill, then it could be cut at the last minute" (interview extract with an "adjunct professor at various times over the last 30 years"), http://gothamist.com/2015/04/16/fight for 15 march nyc.php

6 See for example: http://www.lemonde.fr/idees/article/2016/06/16/la-precarisation-de-l-enseignement-superieur-et-de-la-recherche-nous-asphyxie 4952106 3232.html (in French). 
by their own technical skills, the "hack vs. yack" debate actually draws attention to the fact that the "computational" societies (Berry 2014) are still societies where the domination is distributed according to the recognition in one's work of his abilities of theoretical or conceptual elaboration. Hence, it should primarily be considered as a triple call for recognition:

- Firstly, recognition that the technical practice, especially within one's academic profession but also that of so-called "technical" staffs, is also informed by theory as the digital has come to reshape the ways humanities and social sciences are done;

- Secondly, recognition that the scientific theory in these domains should seriously consider this very fact and inform its reflection with practical digital knowledge;

- Therefore, recognition that "developing a form of digital literacy can be seen as a process that goes hand in hand with developing critical literacy" (Adema 2012).

Indeed, for many DHers, the historical character of many works and productions in the humanities must be criticised, and scholars as well as students should be aware of its current position in the "power structures and relations that shape knowledge" (Adema 2012). In this respect, some critical digital humanities' specialists have argued that new uses of the digital technologies in the processes of producing academic work can help create new forms of resistance to address the problems of power relations that are also embodied in the usual academic practices. Hence their call for a general change in the rules that govern what is considered valid work, usually under the "hacking academy" watchword (Cohen and Scheinfeldt 2011); a change that could also renew the place and role academia should take within societies and the ways of disseminating knowledge $^{7}$ (Burdick et al. 2012; McPherson 2009). Through this "hacking" practice within academia, it is therefore even said that "the spread of $\mathrm{DH}$ is 'remaking the power dynamics of faculty, students, and alternative academics"' (Pannapacker 2013). DHers have thus built their theoretical frameworks on many critical references stemming from American pragmatism - see Gold 2012; Reber and Brossaud 2013 - as well as "French theory" or cultural studies authors - see Berry 2012; Hayles 2012; Jones 2014; McCarty 2005 - whose aim is to exacerbate these individual powers of acting. Some $\mathrm{DH}$ scholars even compare, in this regard, the rise of digital humanities with earlier rises in critical thought and institutions such as the Birmingham School or the Yale Deconstruction (Kirschenbaum 2012; 2014), even though others, drawing on the same critical references, have stated that the question of race (Cong-Huyen 2013; McPherson 2012) or gender relations still needs to be addressed in the field.

These post-Marxist or post-structuralist references usually tend towards a theoretical pragmatism that also lies in both the famous "more hack; less yack!" and "hacking academy" catchphrases: this is where these mottos enter the debate between theory and practice. The digital being merely a set of practices, it is through practical experimentations that the theories should arise: even though the definitions of the concept of "hacking" may vary throughout the DH corpus, this seems to be at least the general point of agreement. Not unlike other movements that emerged with and around the

${ }^{7}$ On this very matter, the debates concerning Open Science and Open Access are regularly treated within the digital humanities corpus (cf. Granjon \& Magis 2015; McGrail 2017) as well as the necessity of switching to free or Open source software (cf. Kulawik 2016; Lane 2016). 
digital tools (Wikipedia, Pirate parties, etc.), the digital humanities encourage a specific kind of "bottom-up" pragmatism, "largely 'inspired' by the technological scripts which they draw upon" (Granjon 2015, 219-20 [trans. CM]). Thus "experimentation", alongside other ethical values such as "collaboration" and "openness", becomes a key element of the DH curriculum (Spiro 2012; Scheinfeldt 2010). And practices facilitated by the digital, such as "remix" (Kuhn and Callahan 2012; Adema 2012) and data-mining (Manovich 2012; Hayles 2012), are celebrated in a concomitant general call for understanding coding as a literacy (Vee 2013; Berry 2012; Digital Humanities Manifesto 2009; Galloway 2004). Finally, this technological pragmatism transfers most of the digital values of its ethos, such as experimentation and collaboration, to the digital tools from which it draws them. Thus, it highlights the necessity of a certain virtuosity in the manipulation of these tools ${ }^{8}$ emphasising especially the novelty of certain practices they permit, such as working on colossal corpuses: "the greatest hope for renewing our shared theoretical traditions in humanities research, and perhaps the only possible route, is to use massive stores of data digitally" (Schmidt 2011). Therefore, one can sometimes in the $\mathrm{DH}$ field perceive an "obsession with quantification" that resembles other parts of digital media research (Fuchs 2017) with an penchant for digital "big data" analyses. This "hands on" pragmatic philosophy is seen as producing knowledge through practice, no matter who is engaged in these production processes, compared to the sometimes-mystifying blathering that has brought some authorised intellectuals to dominant positions within academia. "Hacking" is simultaneously a metaphor for a change within the institution and a pragmatic bottom-up tool for starting to work towards this change.

Taken seriously (which is rarely done, even sometimes amongst DHers), this critique calls for a primacy of the act of making within its broader critique of a division of labour that has brought a domination of the "yack"-workers in universities. I would like to read this call within the philosophical history of theory and practice. Here, the Critical Theory approach can be of great use, especially in relation to the concept of culture industry. Hence we will then see that shifting the critical point of view in the current social conditions, "hack" and "yack" can in fact be considered two sides of the same medal.

\section{Culture Industry and the Division of Manual and Intellectual Labour}

In media, culture or communication studies, the famous work Dialectic of Enlightenment by Theodor Adorno and Max Horkheimer (2002) is usually considered mainly for its central chapter on "Culture Industry: Enlightenment as Mass Deception". The chapter is generally read separately and mistaken for a (consequently imprecise) general socio-economic study of the cultural production of the 1940s (Magis 2016). Although of major relevance concerning the political economy of communications, it seems that most of these socio-economic attempts of understanding tend to reduce one of the book's most important theses. What is at stake here is precisely that the history of domination can be read as a history of the division of manual and intellectual labour, but that, in the name of equality, the intellectual labour (containing the arts as well as philosophy) has lost most of its critical drive. These two correlated propositions can help in analysing the current situation of academia that is outlined by the "hack vs. yack" debate in the digital humanities.

Following in this regard the critical epistemological propositions of their colleague Alfred Sohn-Rethel (1978), Adorno and Horkheimer point out that the modern subject

\footnotetext{
${ }^{8}$ Virtuosity sometimes seen as an aesthetics (see Coleman 2013; Berry 2014).
} 
has been constituted through a separation of the dominant's hands from the most difficult manual tasks. The myth of Odysseus is founding in this respect; especially when sailing past the Sirens' habitat. By means of his cunning trick, Odysseus establishes himself as subject and master and, consequently, as passive recipient of contemplative pleasures:

He knows only two possibilities of escape. One he prescribes to his comrades. He plugs their ears with wax and orders them to row with all their might. Anyone who wishes to survive must not listen to the temptation of the irrecoverable, and is unable to listen only if he is unable to hear. Society has always made sure that this was the case. Workers must look ahead with alert concentration and ignore anything which lies to one side. The urge toward distraction must be grimly sublimated in redoubled exertions. Thus the workers are made practical. The other possibility Odysseus chooses for himself, the landowner, who has others to work for him. He listens, but does so while bound helplessly to the mast, and the stronger the allurement grows the more tightly he has himself bound, just as later the bourgeois denied themselves happiness the closer it drew to them with the increase in their own power. (Horkheimer and Adorno 2002, 26)

This historical scission between aesthetical pleasure and manual labour is then correlated to the domination of the master over the slave or the servant, and goes on for the rest of the history of domination. As well as artistic contemplation, philosophy as an activity is also rooted in this original separation and bears the domination in its very gesture. Thus, the intellectual abilities of the theoretician have been hypostatised within theory itself, as Horkheimer puts it in an essay written around the same time as the Dialectic of Enlightenment:

The human intellect, which has biological and social origins, is not an absolute entity, isolated and independent. It has been declared to be so only as a result of the social division of labor, in order to justify the latter on the basis of man's natural constitution. The leading functions of production-commanding, planning, organizing-were contrasted as pure intellect to the manual functions of production as lower, impurer form of work, the labor of slaves. It is not by accident that the so-called Platonic psychology, in which the intellect was for the first time contrasted with other human 'faculties,' particularly with the instinctual life, was conceived on the pattern of the division of powers in a rigidly hierarchic state. (Horkheimer 1947, 54)

Marx and Engels already had this division of labour in mind when theorising about the German Ideology. Criticising their Young Hegelian colleagues that had come to philosophically assume a definitive separation of forms of consciousness from the social 
being of individuals, Marx and Engels link this separation as it appears to the philosophers with their own social situation in the division of labour, and especially of manual and intellectual labour. As "[f]rom this moment onwards consciousness can really flatter itself that it is something other than consciousness of existing practice, that it really represents something without representing something real; from now on consciousness is in a position to emancipate itself from the world and to proceed to the formation of 'pure' theory, theology, philosophy, morality, etc." (Marx and Engels 1998, 50).

All things considered, we could here compare the Marxian critique with the critique of the "yack" within the digital humanities. And Adorno and Horkheimer draw on these conclusions as well, although they also dialectically consider the fact that this domination is what allowed a constitution of the transcendental mind. In fact, the very gesture of philosophy, though being the privilege of those who mustn't work for their own subsistence, should be a privilege aiming at its own abolition as a privilege. In the intent to conceptualise in abstraction, intellectual labour negates the arduousness of the concrete manual labour and brings about the urge for a reconciliation, by pushing over its very contradiction with manual labour, while it can also plan the conditions of this reconciliation. The transcendental meditation of the "pure" spirit is nothing else than the individual's intellectual attempt to escape the most alienating heaviness of manual labour, therefore considering the latter as its contradictory alien in an intellectual synthesis (Adorno 1998, 22). Adorno finds traces of this thought in the mature Marx: "In the moment of planning - the result of which, he hoped, would be production for use by the living rather than for profit, and thus, in a sense, a restitution of immediacy - in that planning he preserved the alien thing; in his design for a realization of what philosophy had only thought, at first, he preserved its mediation" (Adorno 1973, 192). Through dialectical thinking, that especially considered the category of negation, the intellectual labour should criticise its own existence, thus bearing within itself the whole possible collective emancipation through a synthesis of its contradiction with manual labour. Then, although it never fully reached its own aim, this gesture could never be called "yack", or be compared to what the digital humanities criticise with the "yacking" term.

This is where the central chapter of the Dialectic of Enlightenment proves useful. At an industrial age where the commodity logic has taken over most activities of the social life, the concept of culture industry should be understood as the movement which reduces the mind's ambitions to the triviality of the always-identical. Offered (in exchange of hard cash) as "cultural leisure" in the media as well as "cultural training" in universities, it never escapes the individuality of manual labour, rendering its pretention to be something else futile and ridiculous. It is in fact through the culture industry movement that the theoretical thinking can become this rhetoric flannel that the very term "yack" aims to criticize. And this movement is carried on by positivism and its "pragmatic intelligence" that has come to replace "meditation" within the intellectual labour.

[Freedom for contemplation] was always a privilege of certain groups, which automatically built up an ideology hypostatizing their privilege as a human virtue; thus it served actual ideological purposes, glorifying those exempt from manual labor. Hence the distrust aroused by the group. In our era the intellectual is, indeed, not exempt from the pressure that the economy exerts upon him to satisfy the everchanging demands of reality. Consequently, meditation, which looked to eternity, is superseded by pragmatic intelligence, which looks to the next moment. Instead of losing 
its character as a privilege, speculative thought is altogether liquidated - and this can hardly be called progress.

(Horkheimer 1947, 103)

One could easily notice this paradox: industrial capitalist societies are intellectualknowledge-based. The individuals of these societies are generally well-educated: be it in the European Union, United States, Canada or Japan, the large majority of a generation has attended higher education and almost half of a generation graduated. The data produced by the OECD for 2014 show how 41,6 \% of the 25-34-year-olds of the OECD countries have completed tertiary education and the figures climb up to $44,7 \%$ for France, 45,7 \% for the United Stated, 49, 2 \% for the United Kingdom and even $57,7 \%$ for Canada and 58,8 \% for Japan. ${ }^{9}$ How come, in this case, does a more rational organisation of society still seem utopian? The Critical theorists' answer would be that the intellectual gesture has been shifted: while the intellectual sectors were taken over by industry - and education became a strategic source of profit and control within the entire cultural production - the very act of thinking has been limited to identifying and applying procedures, transforming it into a mere reflection of the industrial machinery. "[l]deas have been radically functionalized" (Horkheimer 1947, 22). The work of Herbert Marcuse on the One-Dimensional Man also criticises this shift, analysing it for instance through Wittgenstein's concepts: "Thinking (or at least its expression) is not only pressed into the straitjacket of common usage, but also enjoined not to ask and seek solutions beyond those that are already there. 'The problems are solved, not by giving new information, but by arranging what we have always known'10" (Marcuse 1991, 182).

Through this shift, in philosophical thinking, in social sciences as well as in others intellectual and cultural sectors, one sees "the growth of the industrial apparatus and of its all-embracing control over all spheres of life" (Marcuse 2004) that rendered thought powerless. Intellectual labour, personified in the professions of managers, experts or consultants, has been emptied of the original social interest of a thought liberated from physical labour. Its new goal is to positively record what is already there, most of the time through the application of mathematical logics which permits an "intellectual economy" (Horkheimer 1947, 23) - and dispense a true act of thinking: "Complicated logical operations are carried out without actual performance of all the intellectual acts upon which the mathematical and logical symbols are based" (23). Then, through this culture industry process, intellectual labour can become true "yack", where the "intellectual" is merely located in the social positions of its practitioners. Culture industry limits the possibility of genuine intellectual labour, but does not stop the social domination the latter operates. In this perspective, it can be said that theory has historically become "yack" with the pregnancy and penetration of the economic and instrumental logics within academia that has turned thought into a mere sector of the culture industry. Is it then possible, on the other hand, to engage in a true act of "hack"?

\section{What Concept for a Practice within the Digital Kulturindustrie?}

Following the main works of the Frankfurt School, one realises how the western societies have reached a point where the division of manual and intellectual labour has no raison d'être outside of domination. And if, on the one side, the need for hard physical

\footnotetext{
${ }^{9}$ See https://data.oecd.org/eduatt/population-with-tertiary-education.htm

${ }^{10}$ Wittgenstein, Philosophical Investigations, 47. (Reference in the cited extract).
} 
labour is now prescribed by the needs of social control rather than by scarcity (Marcuse 1998), also on the other side the "intellectual" planning tasks have increased but merely deal with the application of procedures that are external to the production process instead of aiming at their own liberated self-production. This last shift forms what can be called "bureaucracy": the reduction of intellectual actions to a complex body of tasks offering simplified standardised procedures, which is not at all at odds with the movement of capitalism - although it has been used to mock the soviet countries during the 1960s and 1970s (Graeber 2015). Indeed, Max Weber (1968) has shown the link between the bureaucratic organisation and the complete realisation of the logic of capitalism. As we have seen, bureaucracy is transposed in the social sciences and philosophy by positivism, and the latter draws on the mathematical reasoning and abstract formalisation of reason itself. Through this reasoning, capitalist society reproduces itself in science: "mathematical formalism, whose medium, number, is the most abstract form of the immediate, arrests thought at mere immediacy. The actual is validated, knowledge confines itself to repeating it, thought makes itself mere tautology. The more completely the machinery of thought subjugates existence, the more blindly it is satisfied with reproducing it" (Horkheimer and Adorno 2002, 20).

Yet the digital exacerbates this penetration of the mathematical reasoning over society as well as consequent bureaucratisation. As some representatives of the critical current in digital humanities state, the "computational" rationality of the digital is of the same kind than the abstract instrumental rationality that culminates in positivism after having dominated the whole bourgeois sciences and philosophy. "Digitalisation is abstractisation: it extracts a small amount of 'relevant' characteristics from something concrete and continuous in order to (reductively) summarise it in calculation, while neglecting myriad other characteristics just as real but considered 'irrelevant'" (Citton 2015, 49 [trans. CM]). The mathematical rationality, the aim of which is the final equivalence of any qualitative data, is the very basis of digital form: "the use of computational systems creates a highly computationally mediated lifeworld which raises challenging questions that Horkheimer envisioned already in 1947 when he talked about the prevalence of science as the arbiter of knowledge and truth" (Berry 2014, 47). Indeed, the digital systems "are also built of computational logics which are themselves materializations of assumptions, values and norms, often taken for granted, by the designers and programmers of the systems (e.g. gender, race, class, etc.)" (40). Those unquestioned computational logics draw on the mathematical reasoning in pursuit of the same "intellectual economy" as in positive scientific thought. It even renews a myth of universal logical understanding as "the history of computation is imbued with grand visions of a unified theory on the basis of mathematics" (Rieder and Röhle 2012, 78).

Then, beyond its mere slogan aspect, the fact that DHers call for "more hack!" aims to address this matter and question the unquestioned, by the means of what is unquestioned:

[W]e need to develop methods, metaphors, concepts and theories in relation to this software and code to enable us to think through and about these systems, as they will increasingly have important critical and political consequences. That is why being able to read these code-based protocols is an important starting point (Berry 2014, 40). 
It is necessary indeed to encourage such practices. But more understanding of the rules of the computational languages does not equal their subversion. Also, this invitation sometimes reveals a strange nostalgia for a simpler artisan life that would however take place in the digital age. Many works in digital humanities exhort their readers to develop "code craftsmanship" following in this regard the pleas of many digital celebrating events such as "Maker Faires" and "Hackatons" (Svensson 2016). This at times techno-romanticism does not assure a final reflexivity on the protocols themselves. Quite the opposite: although learning code can lead to "protocol teardowns [...] for seeing the limits of reading code by breaking code" (Berry 2014, 40), it is also a learning of the mathematical logic embedded in the scripts. Hence, it finally leads to an incorporation of the latter's instrumental reason as it hopes that a certain virtuosity in it is the starting point of a wider critique. But should the optimism of the more enthusiastic hackers-DHers be tempered or not on this last point, the whole argument appears stuck in quite a utilitarian vision, so much so that "the distinctive methodologies of digital humanities are typically represented in comfortingly industrial terms" (Cecire 2011). It may not be a renewed critical practice that could count as a contradiction for the rhetoric flannel that "theory" has become, as much as the learning of the core script of society's instrumental reason. Yet was this not industrial instrumental reason, its implacable positivist logic, its inexorable dissemination and its bureaucratic consequences that nipped the possibility of a critical thought in the first place? In the computational societies, the possible "hack" has merely become what the term "yack" aims to criticise: in each case, it is a learning and an application of external procedures, a restriction of the possibilities of both the thought and the making to manipulating logics that have been conceptualised elsewhere, for reasons of intellectual economy. Thus the difference between the two finally resides in the theoretical or practical consciousness as well again as the recognised social position of the subject as for both, the manipulation of the mathematical reasoning is a manipulation of an abstract-form that "owes no debt to manual labour" (Sohn-Rethel 1978, 36): be it "hacking" or "yacking", both are privileged actions that are kept away from the hardest physical productive tasks.

Furthermore, one should consider that these computational logics have accompanied the expansion of the service sector in the economies of the North, along with their own technological imaginations that the general techno-pragmatic call of the digital humanities aims to critique as well, especially since 2015 through a workshop called "Minimal Computing", within the field. ${ }^{11}$ Some notions such as "cyberspace" (Jones 2014; Mosco, 2005), "information society", "post-industrial society" (Fuchs 2014) or "creative industries" stem from these imaginations and have proliferated with the reorientations of the production base of the countries of the North towards the culture, information and knowledge economies after the oil shocks from the end of the 1970s onwards that resulted in the growth of computerisation and the rise of ICTs as well as of the massive development of the higher education and research sectors.

As many works in political economy of communications have shown, these reorientations and the increasing development of the digital technologies have been at the centre of a global redistribution of the division of labour. The unskilled or low-skilled labour is located in the developing countries whereas the skilled management, research and development tasks are located in the "First World" (Mosco 2009; Sussman and Lent 1998). And this international division of labour is also still shaped as a general division between head and hand: the unskilled or low-skilled tasks been essentially

${ }^{11}$ http://go-dh.github.io/mincomp/about/ 
extraction of minerals (the raw materials in the production of ICTs) or assembling (Fuchs and Sandoval 2014). In its so-called "post-industrial" era, capitalism is still based on the high exploitation of different kinds of labour, the most physical manual types being concentrated in the countries at the peripheries, in the form of "the highly exploited bloody Taylorist work and slave work [...] producing hardware and extracting "conflict minerals"' (Fuchs 2014, 130). This also means that, in the current culture industry, "hack" and "yack" which are merely the same both count as parts of the skilled management and R\&D tasks whose very existence rests upon the fact that the hardest physical productive tasks of the global economy are carried out elsewhere. ${ }^{12}$ Furthermore, they are both based on the same instrumental logic that renders them critically powerless while it increases exploitation and control upon the enslaved work of individuals in the Third World. In fact, in its current state, capitalism needs intellectual debates about "hack" and "yack" concerning ICTs, as mediated by ICTs, and as the blood of the African mine workers to produce these ICTs. Genuine intellectual labour should be aiming towards the ending of this situation.

\section{Aiming Below the "Theory vs. Practice" Debate: The Political Role of Aca- demic Labour}

As we see, the "hack vs. yack" debate in the digital humanities reveals genuine critical questions about the field of academic critical thought in general, should one take it seriously - what any reader ought to do given the widely documented critical turn in the field around 2015 onwards. This debate cannot be limited to the sole technical matter: it is an actual critique of the situation of academia embodied in a more general question of the relations between academic theory and practice. And finally, as the situation of theory itself proves that it merely is an abstract tool of domination, while the prevalence to give to the "hack" technical practice over the theory also shows limits, a synthesis appears necessary. However, explored through a critical-theoretical framework, a resolution might not be this debate's most interesting stake. And it may be the biggest trap in which some thinkers tend to fall, when calling for the constitution of a "critical praxis" (Adema 2012) that would articulate digital literacy and theoretical knowledge (Fitzpatrick 2011; Schmidt 2011), beyond what appears to be an outmoded debate of "hack" over "yack": "[t]he dichotomy between the manual realm of making and the mental realm of thinking was always misleading. Today, the old theory/praxis debates no longer resonate" (Digital Humanities Manifesto, 2009). Because, here as for the rest of the critical academic field, the plea for this articulation should analyse the situation of both theory and practice to see what can be expected from their reunion. If the digital enables a technical articulation of informatics, of audio-visual media as well as of the telecommunications with the equivalent treatment of data, it does not facilitate a "convergence" of theory and praxis outside of a mere capitulation to the general instrumental logic that the critical theoretical work of the humanities aims to hold back. And when the Digital Humanities Manifesto (2009) states that "[k]nowledge assumes multiple forms; it inhabits the interstices and criss-crossings between words, sounds, smells, maps, diagrams, installations, environments, data repositories, tables, and objects. Physical fabrication, digital design, the styling of elegant, effective prose; the juxtaposing of images; the montage of movements; the orchestration of sound: they are all making", it assumes that the categories of theory and practice have both

12 It is therefore not insignificant that most of the growth of the $\mathrm{DH}$ field has taken place in the countries of the North, as we have seen. (See http://www.ucl.ac.uk/infostudies/melissa-terras/DigitalHumanities/nfographic.pdf) 
merely lost their very concept in the current society of globalised culture industry. Notably, here, although this "making" opens an enthusiastic world of cultural-technical possibilities in which lettered technicians can engage to renew the practices of the humanities, it doesn't mean a synthesis of theory and practice - and besides, of manual and intellectual labour - but rather a continuation of the culture industry domination logic through technical virtuosity.

Therefore, it may be below the debate rather than beyond it that a critique in the $\mathrm{DH}$ field should aim, in a two-fold movement:

- Keeping the possibility for a true theoretical critical work which tries to reflexively criticise itself as "intellectual labour" as well as criticising the digital practices that inform its own critique. This counts for theory;

- Drawing the practical consequences of this academic critique on a political level. This only can be considered praxis.

If another radical experience can be, it is located in the voluntarily maintained tension between theory and practice. It is this assumed tension which never forgets that the labour of theory is wrested from the hardest productive tasks and that, as a privilege, it negates the actual social logic and its most subjugating tendencies - even though academics are not the ones who suffer these the most. This maintained tension should render obvious that the current bureaucratised "intellectual labour" produced in the universities is way below its own concept in the humanities. Hence, "[t]echnological engagement and critical work need to be brought together, and doing so requires allowing digitally inflected exploration and experimentation. We also need a conceptual foundation for humanities infrastructure that is not just built on science and engineering models but makes deep sense from the point of view of humanities-based questions and activities" (Svensson 2016). But it should not be forgotten that this whole part can only aim towards a theory that deserves to be called so.

From then on, it should invite tenured academics as well as precarious faculties to politically engage in social movements for a change in working conditions. These political movements should identify the bureaucratic logic of the "yack" with the movement of capitalism that also exploits and kills manual labour, be it extracting labour in Western Africa, assembling labour in South-Eastern Asia as well as the low-skilled work in the societies of the North - in short, experience that "everything if false as long as the world is as it is" (Adorno and Horkheimer 2011, 69). I finally agree with Benjamin Schmidt that the "[w]ork in digital humanities should always begin with a grounding in a theory from humanistic traditions" to avoid reproducing "a problematic social world" (Schmidt 2011). Yet it must be added that trying to avoid this problematic reproduction can't stop at this grounding in a theory: it must inform and be followed by a political praxis, as the critique of the problematic social world and of its socialised economy is always political, although the political critique can be facilitated by an adequate use of the current digital techniques. The critical DHers should consider that the "hack vs. yack" debate is in fact only one side of the tension between theory and praxis: the one that calls for a true theory - be it in tension with other areas of social life that have historically been dominated by the intellectual workers. And this tension shouldn't aim towards a synthesis - as "syntheses" has for long been the word used to acclaim the victory of capital in the theoretical field - but rather towards its own implosion, by political means. 
In the highly consensus-seeking times that we currently live in the universities (as in many other areas of social life), it seems that every debate must end with the emergence of a "reasonable" posture which caricatures the two debating positions to highlight the necessity of a "middle way" that rhetorically appears as the only tenable position. Consequently, when confronted to a position rhetorically materialised in a sentence starting with the word "beyond", one should keep oneself on his toes! For this is usually where the sought consensus is going to come from. And a rapid glimpse at most of the epistemological debates in media and communication studies will reveal how our theoretical epoch is a time of "beyonds". ${ }^{13}$ But most of the time, these positions that are self-proclaimedly "beyond" any debate rarely draw on an actual integration of the debate in question: there's generally no dialectical aufhebung to be found there, but a rather postmodernist parody of it that leads thoughts nowhere else than to this urge for consensus. And finally, to the idea that fundamental antagonisms are inexistent within contemporary societies. Therefore, it might sometimes be useful to "come back from the beyond" to realise that a dialectical integration cannot be operated; that a debate should exist with its own specific tension, following in this respect the famous phrase of Adorno, according to which "the whole is the untrue" (Adorno 2005, 50). And it is certainly the case with the eternal debate of theory vs. practice, especially considering its formulation within digital humanities. In fact, the specific form this debate takes in the digital humanities does quite reveal the situation and the possibilities of the theoretical as well as the practical elaborations in the current northern societies - particularly within the academic field. There is no middle way to find between "hack" and "yack" because, under the current social conditions, there is no real tension between these two. Put otherwise, the middle way already exists and that is the actual logic of capitalism in the global culture industry - the same neoliberal middle way that once predicted that digital capitalism should be the reunion of "both the Marxist and the neoliberal utopias" (Levy 2002, 172 [trans. CM]). Thus, in a general academic ethos that has incorporated this very logic and urges scholars never to seek truth outside the borders of their scholarly field, the apparent necessary reunion of theory and practice may not be anything else than the mixing of a mere parody of both. Humanists or social scientists, should they call themselves "digital" or not, must then never forget that their engagement in intellectual labour should be aimed at the production of a (critical) theory. And they should not be ashamed to push this concept of theory beyond the limits of what the current academic rules would admit. The scientific injunction to be theoretic-practical can be a mere consensual ploy, whose link with the logic of culture industrialisation is traceable, aimed at reducing the most critical consequences of a genuine theoretical work. For the latter, the actual theory is one that is not afraid of speculative thought, even if it must be informed by the current digital practice. It is an act of intellectual labour that one must never forget is, as such, a privilege that should thus be at least directed at fulfilling its very concept of theory. But under the current conditions, the actual praxis to engage this intellectual labour with is out of the academic realm and out of the technical realm: it should be political.

${ }^{13}$ Indeed, the examples are numerous: beyond political economy vs. cultural studies; beyond philosophy vs. social sciences approaches; beyond culture vs. commerce, etc. 


\section{References}

Adema, Janneke. 2012. Practice What You Preach. Engaging in Humanities Research through Critical Praxis. Accessed February 20, 2017. https://openreflections.wordpress.com/2012/01/30/practice-what-you-preach-engaging-in-humanities-researchthrough-critical-praxis/

Adorno, Theodor W. 2005. Minima Moralia. London: Verso.

Adorno, Theodor W. 1998. Hegel: Three Studies. Cambridge, MA: MIT Press.

Adorno, Theodor W. 1973. Negative Dialectics. New York, NY: Continuum.

Adorno, Theodor W., and Max Horkheimer. 2011. Towards a New Manifesto. London: Verso.

Alvarado, Rafael C. 2012. 'The Digital Humanities Situation'. In Debates in the Digital Humanities, edited by Matthew K. Gold, 50-55. Minneapolis, MN: University of Minnesota Press.

Alvarado, Rafael C. 2011. The Effective Humanist: On Not Misrecognizing the Work of Digital Scholars. In \#Alt-Academy: 01. Alternative Academic Careers for Humanities Scholars. Media Commons.

Berry, David M. 2014. Critical Theory and the Digital. New-York, NY: Bloomsbury.

Berry, David M., ed. 2012. Understanding Digital Humanities. London: Palgrave MacMillian.

Broca, Sébastien. 2016. Épistémologie du code et imaginaire des «SHS 2.0 ». Variations. Revue internationale de théorie critique, no. 19. Accessed 24 January 2018. http://variations. revues.org/701

Burdick, Anne, Johanna Drucker, Peter Lunenfeld, Todd Presner, and Jeffrey Schnapp. 2012. Digital Humanities. Mit Press.

Cecire, Natalia. 2011. Introduction: Theory and the Virtues of Digital Humanities Journal of Digital Humanities. Journal of Digital Humanities 1 (1). Accessed February 20, 2017. http://journalofdigitalhumanities.org/1-1/introduction-theory-and-the-virtues-of-digital-humanities-by-natalia-cecire/

Citton, Yves. 2015. Subjectivations computationnelles à l'erre numérique. Multitudes 62 (1): 45-64.

Cohen, Dan, and Tom Scheinfeldt, eds. 2011. Hacking The Academy. A Book Crowdsourced in One Week. Ann Arbor, MI: University of Michigan.

Coleman, E. Gabriella. 2013. Coding Freedom. The Ethics and Aesthetics of Hacking. Princeton, NJ: Princeton University Press.

Cong-Huyen, Anne. 2013. Race in DH - Transformative Asian/American Digital Humanities. Accessed February 20, $2017 . \quad$ https://anitaconchita.wordpress.com/2013/09/24/cesa2013-race-in-dh-transformative-asianamerican-digital-humanities/

Doueihi, Milad. 2011. Digital Cultures. Cambridge, MA: Harvard University Press.

Fitzpatrick, Kathleen. 2011. 'The Humanities, Done Digitally'. The Chronicle of Higher Education. Accessed February 20, 2017. http://www.chronicle.com/article/The-HumanitiesDone-Digitally/127382/

Fuchs, Christian. 2017. From Digital Positivism and Administrative Big Data Analytics Towards Critical Digital and Social Media Research! European Journal of Communication 32 (1): 37-49.

Fuchs, Christian. 2014. Digital Labour and Karl Marx. London: Routledge.

Fuchs, Christian, and Marisol Sandoval. 2014. Digital Workers of the World Unite! A Framework for Critically Theorising and Analysing Digital Labour. tripleC: Communication, Capitalism \& Critique 12 (2): 486-563.

Galloway, Alexander. 2004. Protocol: How Control Exists After Decentralization. Cambridge, MA: MIT Press.

Gold, Matthew K., ed. 2012. Debates in the Digital Humanities. Minneapolis, MN: University of Minnesota Press.

Graeber, David. 2015. The Utopia of Rules. Brooklyn, NY: Melville House Publishing. 
Granjon, Fabien. 2015. Du pragmatisme et des technologies numériques. Hermès, La Revue $n^{\circ} 73$ (3): 219-24.

Granjon, Fabien, and Christophe Magis. 2016. Critique et Humanités Numériques. Pour Une Approche Matérialiste de l'Immatériel. Variations, no. 19. Accessed 24 January 2018. https://variations.revues.org/pdf/748

Granjon, Fabien, and Christophe Magis. 2015. Vers Une "Nouvelle Anthropologie" Critique? Jalons Pour Une Épistémologie Matérialiste Des Humanités Numériques. Journal Des Anthropologues, no. 142-143: 281-303.

Grusin, Richard. 2013. 'The Dark Side of the Digital Humanities - Part 2'. Thinking C21.

Hayles, N. Katherine. 2012. 'How We Think: Transforming Power and Digital Technologies'. In Understanding Digital Humanities, edited by David M. Berry, 42-66. London: Palgrave MacMillian.

Hesmondhalgh, David. 2007. The Cultural Industries. London: Sage.

Himanen, Pekka. 2001. The Hacker Ethic and the Spirit of the Information Age. New-York, NY: Ransom House.

Horkheimer, Max. 1947. Eclipse of Reason. New York, NY: Oxford University Press.

Horkheimer, Max, and Theodor W. Adorno. 2002/1944. Dialectic of Enlightenment. Stanford, CA: Stanford University Press.

Jones, Steve E. 2014. The Emergence of the Digital Humanities. New-York, NY: Routledge.

Kuhn, Virginia, and Vicki Callahan. 2012. Nomadic Archives: Remix and the Drift to Praxis. In Digital Humanities Pedagogy. Practices, Principles and Politics, edited by Brett D. Hirsch. Cambridge: OpenBook Publishers.

Kulawik, Bernd. 2016. Why and how to avoid complex non-free software in Digital Humanities projects. Information Services and Use 36: 203-210.

Lane, Richard J. 2016. Revisiting Open Source Software Development Models for Community-Based Digital Humanities Research Generation. Scholarly and Research Communication, 7 (2).

Levy, Pierre. 2002. Cyberdémocratie. Paris: Odile Jacob.

Magis, Christophe. 2016. Économie Politique de la Communication et Théorie Critique des Médias. Épistémologie d'un Héritage Théorique Critique.' Réseaux 34 (199): 43-70.

Manovich, Lev. 2012. Trending: The Promise and the Challenges of Big Social Data. In Debates in the Digital Humanities, edited by Matthew K. Gold. Minneapolis, MN: University of Minnesota Press.

Marcuse, Herbert. 2004. Collected Papers of Herbert Marcuse, Vol. 1: Technology, War and Fascism. Edited by Douglas Kellner. London: Routledge.

Marcuse, Herbert. 1998/1955. Eros and Civilization. A Philosophical Inquiry into Freud. New York, NY: Routledge.

Marcuse, Herbert. 1991/1964. One-Dimensional Man. London: Routledge.

Marx, Karl, and Friedrich Engels. 1998/1845. The German Ideology. Amherst, NY: Prometheus.

McCarty, Willard. 2005. Humanities Computing. Basingstoke, Hampshire: Palgrave MacMillian.

McGrail, Anne B. 2017. Open Source in Open Access Environments: Choices and Necessities, Minimal Computing. Accessed 24 January 2018. http://go-dh.github.io/mincomp/thoughts/2017/02/17/mcgrail-choices/

McPherson, Tara. 2012. 'Why Are the Digital Humanities so White? Or Thinking the Histories of Race and Computation'. In Debates in the Digital Humanities, edited by Matthew K. Gold, 139-60. Minneapolis, MN: University of Minnesota Press.

McPherson, Tara. 2009. 'Introduction: Media Studies and the Digital Humanities'. Cinema Journal 48 (2): 119-23.

Mosco, Vincent. 2009. The Political Economy of Communication. Thousand Oaks, CA: Sage. 
Murray-John, Patrick. 2011. Theory, Digital Humanities, and Noticing. Journal of Digital Humanities 1 (1). Accessed 24 January 2018. http://journalofdigitalhumanities.org/1-1/theorydigital-humanities-and-noticing-by-patrick-murray-john/

Nowviskie, Bethany. 2011. Where Credit Is Due: Preconditions for the Evaluation of Collaborative Digital Scholarship. Profession 13: 169-81.

Pannapacker, William. 2012. "No DH, No Interview". Chronicles of Higher Education, http://www.chronicle.com/article/No-DH-No-Interview/132959

Pannapacker, William. 2013. "Hacking" and "Yacking" About the Digital Humanities. Chronicles of Higher Education 60 (1). Accessed 24 January 2018. http://www.chronicle.com/article/HackingYacking-About/141311

Reber, Bernard, and Claire Brossaud. 2013. Conclusion. In Digital Cognitive Technologies: Epistemology and the Knowledge Economy, 389-96. Hoboken, NJ: John Wiley \& Sons.

Rieder, Bernhard, and Theo Röhle. 2012. Digital Methods: Five Challenges. In Understanding Digital Humanities, edited by David M. Berry. London: Palgrave MacMillian.

Scheinfeldt, Tom. 2010. Why Digital Humanities Is "Nice". Found History. Accessed February 20, 2017. http://foundhistory.org/2010/05/why-digital-humanities-is-nice/

Scheinfeldt, Tom. 2008. Making It Count: Toward a Third Way. Found History. Accessed February 20, 2017. https://foundhistory.org/2008/10/making-it-count-toward-a-third-way/

Schmidt, Benjamin M. 2011. 'Theory First'. Journal of Digital Humanities 1 (1). Accessed February 20, 2017. http://journalofdigitalhumanities.org/1-1/theory-first-by-ben-schmidt/

Schreibman, Susan, Laura Mandell, and Stephen Olsen. 2011. Evaluating Digital Scholarship. Introduction. Profession 79: 123-201.

Schreibman, Susan, Ray Siemens, and John Unsworth, eds. 2004. A Companion to Digital Humanities. Oxford: Blackwell.

Sohn-Rethel, Alfred. 1978. Intellectual and Manual Labour. A Critique of Epistemology. Atlantic Highlands, NJ: Humanities Press.

Spiro, Lisa. 2012. Opening up Digital Humanities Education. In Digital Humanities Pedagogy. Practices, Principles and Politics, edited by Brett D. Hirsch. Cambridge: OpenBook Publishers.

Sussman, Gerald, and John A. Lent, eds. 1998. Global Productions: Labor in the Making of the 'Information Society'. Thousand Oaks, CA: Sage.

Svensson, Patrik. 2016. Big Digital Humanities: Imagining a Meeting Place for the Humanities and the Digital. Ann Arbor, Ml: University of Michigan Press.

Terras, Melissa. 2011. Peering Inside the Big Tent: Digital Humanities and the Crisis of Inclusion. Melissa Terras' Blog. Accessed February 20, 2017. http://melissaterras.blogspot.com/2011/07/peering-inside-big-tent-digital.html

Vee, Annette. 2013. Understanding Computer Programming as a Literacy. Literacy in Composition Studies 1 (2): 42-64.

Weber, Max. 1968. Economy and Society: An Outline of Interpretive Sociology. Berkeley, $\mathrm{CA}$ : University of California Press.

\section{About the Author}

\section{Christophe Magis}

Christophe Magis is Lecturer (Maître de conferences) of Communication and Media Studies at Université Paris 8 (France) and a member of the Cemti Laboratory. His research focuses on the critical political economy of the cultural and communication industries and the epistemology of critical theories in communication studies. 


\title{
Anger in Academic Twitter: Sharing, Caring, and Getting Mad Online
}

\author{
Karen Gregory* and sava saheli singh** \\ *University of Edinburgh, Edinburgh, UK, k.gregory@ed.ac.uk \\ **Queen’s University, Kingston, Canada, sss7@queensu.ca
}

\begin{abstract}
This article examines two different cases or "events" in Twitter to understand the role that negative emotions play in online discussions of academic labour. As academic labour conditions deteriorate and academics take to online spaces, they do so to critique, connect, and organize. We suggest that negative emotions may play a productive role in raising awareness of labour issues, as well as serving as a site for organizing across academic hierarchies and beyond the university. Additionally, negative emotions may fuel the production of new networks, personal, and professional connections. However, as we show, anger online can also provoke substantive repercussions, both personally and institutionally. We suggest that paying attention to the role that negative emotions play on Twitter can help academics gain a better sense of how to use their digital labour for collective action.
\end{abstract}

Keywords: Academic Labour, Twitter, Emotion, Emotional Labour, Affective Labour, Academic Freedom, Adjunct Labour, Anger

\section{Introduction}

Digital media and digital technologies shape the working conditions of academia, informing research, teaching, and administrative practices and scholars have begun to document the ways in which digital technologies are changing the nature of labour in the University (Poritz and Rees 2016; Newfield 2016; Watters 2016; Flanders 2012). Increasingly, social media platforms play a role in that digital landscape, as academics across university hierarchies are encouraged to develop public digital media presences through the use of blogs, websites, and/or social networking platforms (Weller 2011; Carrigan 2016; Daniels and Thistlethwaite 2016). Despite the role that such media play in academic life and the ways in which social media can shape individual academic identity, reputation, and career opportunities (singh 2017), less attention has been paid to social media explicitly as a site of work and labour and as a site of value to the larger institution of higher education. In addition to reshaping academic time and attention, social media also establishes what Willinsky (2010) has called "reputational economies," in which increased academic reputation online affects the types of academic work that are produced, published, and distributed. While such economies can raise questions about the nature of scholarship (Moorish 2016), they also raise questions about ownership and value creation. As Hearn $(2010,435)$ has documented, "reputation seekers" do not own or control "the means of our own distribution." For Hearn, online reputation serves as fodder for data aggregators and measurement systems, which are used to increase market value for corporations.

While studies have begun to explore the mundane, emotional, ongoing experiences of academic social media usage (Mewburn and Thomson 2013; Lupton 2014; Veletsianos 2016; Pausé and Russell 2016), research is required to understand pre- 
cisely how social media platforms shape the broader terrain of academic labour and labour debates in higher education, particularly as work in the university is intensified and extended beyond the confines of the office, classroom, and staff meeting. As scholars draw links between accelerated working conditions and poor mental health and well-being (Hall 2014; Bowles and Hall 2014; Mountz et al. 2016), it is imperative that we understand how digital media may be exacerbating or ameliorating those linkages and demonstrate how the "free labor" (Terranova 2000) such platforms demand add to current pressures facing academics. However, as such social media platforms are also specifically designed to give rise to "branded" content, we must question not only how social media may be commodifying academic pressures, but also note how it has given rise to new spaces for discussion, debate, and even organizing.

This article is drawn from ongoing research into the labour of digital scholarship (Gregory 2017) and into the formation of academic identity in the digital age (Singh $2015 ; 2017)$. We analyse two Twitter "cases" to study the role that negative emotions, with a particular focus on anger, played in the unfolding of the event. The first case is an event denoted by the hashtag \#iammargaretmary, which emerged in response to the death of the Duquesne University adjunct professor Margaret Mary Votjko and became an emblem of ongoing debates and discussions of adjunct labour and exploitation. The second case looks at a series of events involving academics on Twitter whose tweets about race and racism were taken out of context and used to put pressure on their institutions to take action against them. These events generated an ongoing debate online about the nature of academic freedom, as well as about the role of Twitter and the inherent risks of being an academic in public. In each event, we saw a groundswell of emotion, much of it inspired by anger at academic labour conditions and at the state of academic governance. In addition to platformbased sharing, "favoriting," and commenting, both events also generated writing beyond the Twitter platform, in the form of blog posts, and garnered media attention beyond Twitter and beyond the academic community.

While the word "brand" is often used as a pejorative in academic circles, this article takes seriously the notion that academic digital presences and social media platforms "do work," which is to say they generate, circulate, and monetize individual academics, research projects, publications, and university reputations more broadly. Such media presences increasingly play a role in the production of what has been called "academic capitalism" (Slaughter and Rhoades 2004), which denotes the increasing marketization and commodification of knowledge production, as well as play a role in the ongoing "neoliberalization" of the University (Darder 2012; McCarthy 2011; Apple 2009). While not all academic media presences are brands, they are often cultivated, curated, and maintained via platforms that are themselves brands and that intentionally give rise to branded content through their design (Papacharissi 2013, 146). Academic social network sites like Academia.edu and ResearchGate provide further opportunity for academics to establish their academic reputations. However, as Jordan $(2014 ; 2016)$ found, these spaces privilege those academics with already established reputations and networks over those who are starting anew.

As online spaces, particularly social media, come to be seen as "affective publics" (Papacharissi 2015) that rely heavily on personal "content" generation, personal experience, and emotion, it is essential to pay attention to the risks and ramifications of this work - both for academics themselves and for institutions more generally. To suggest that institutional policies adequately address these issues is an understatement. However, in this article we argue that observations from contemporary Twitter 
"events" can serve as a starting point and can help us understand the role that negative emotions may play in the circulation of the event, as well as serve as a case study for interrogating university responses. In the absence of clear labor protections for academic workers such analyses can be used to advocate for policy and help academics navigate online spaces.

While elements of these events can be subject to critiques of hashtag activism or "clicktivism," we suggest the emotional labour they mobilized is productive. It is not simply "captured" by the platform, nor does it go to waste. Rather, we suggest that Twitter is able to raise awareness of academic labour issues across academic hierarchies, as well as beyond the university. Furthermore, these events gave rise to opportunities for organizing and, as these events can "tarnish" university brands, there is potential there for faculty to gain some leverage. However, such tarnishing can also backfire. While nonetheless raising awareness of important issues, online negative emotions can "stick" to an individual more readily than they can to an institution, causing distress, anxiety, physical harm, or job loss, and here we must ask: "Can negative emotions be mobilized online in a way that does not contribute to the already hostile spaces that academics find themselves in?"

\section{Feeling Like "Shit" in the University}

Numerous scholars have now documented long-standing shifts in higher education that have brought about what is often referred to as the "corporate" university (Washburn 2003; Ross 2010) or the "neoliberal" university (Slaughter and Rhoades 2000). As Beetham $(2016,48)$ writes,

these changes can be characterised as: insecurity; rapid cycling or shortened timescales; blurring of boundaries between personal and work time/space; disaggregation of the 'functions' of academic work; continual monitoring and assessment of 'performance'; entrepreneurialism; and the transfer of academic management/organisation to digital systems.

As Gregory and Winn (2016) note, these shifts in labour conditions are often broadly spoken of in the language of "crisis" or as the university in "ruins" (Readings 1996). However, as Winn (2016) suggests, despite the identification of crisis and calls for greater unionization among academics, academic labour conditions continue to decline. As Gill $(2009,46)$ documents, not only has precariousness become a defining feature of academia (particularly for graduate students and junior scholars), but so has "a punishing intensification of work has become an endemic feature of academic life." Kate Bowles and Richard Hall (2014) have labelled the university "an anxiety machine" and, as Hall writes in a 2016 blog post, as the university is restructured to maximize value, "academics and students are separated and exploited through their abstract labour", or what can be thought of as the time and energy and the capacities require to work. Such separation is as much physical and material as it is an emotional experience of exploitation. Bousquet $(2008,27)$ has even suggested that those who bear the brunt of the crisis - graduate students and contingent faculty - understand that 
they are not merely treated like waste but, in fact, are the actual shit of the system - being churned inexorably toward the outside: not merely 'disposable' labor, but labor that must be disposed of for the system to work.

Given that such conditions are structural and endemic - and lived out by individuals it is perhaps no surprise that new spaces for academic discussion and academic life are being carved out in and through digital media and platforms and that those spaces both modify academic anger as well as give voice to it.

As Mewburn and Thomson $(2013,1106)$ found in their study of academic blogs, academics online "most commonly write about academic work conditions and policy contexts, share information, and provide advice." Such bloggers combine research and teaching posts with broader discussions of work practices. In contradiction to the notion that academic blogging is driven solely by self-interest or the desire to market one's work, such blogs are written for other academics, functioning as both part of the "gift economy" and as a "virtual staff room" (Ibid.). As they suggest, there is no explicit guide or handbook encouraging academics to use online spaces for "speaking back to power" (Ibid., 1111); however, as their study finds, this is precisely how academics are using their blogs (at least some of the time). Blog writing "appears to offer some academics an alternative to resistance, compliance or pragmatism in the face of managerialism in higher education" (Ibid.).

As Mewburn $(2011,321)$ found, such "troubles talk" online can help PhD students "negotiate and manage the precarious process of 'becoming academic.'" As PhD student Lisa Kalayji (2017) recently wrote on her academic blog:

Doing a PhD comes with many pleasures and pitfalls. Under the yoke of the neoliberal university, a lot of those pitfalls have been exacerbated, and their costs heightened. The magnification of academic cultures of competition and self-marketing, the desperate shortage of academic jobs, and increasing casualisation of academic workforces bear down on our shoulders, squeezing and structuring the way that we think and feel in daily academic life. There's a lot to be angry and grieved about.

Kalayji's words echo Gill's claim that managing the contradictions of academic labour conditions has become a defining feature of academic life, particularly for those attempting to enter the profession. In this regard, blogs and other social media can offer the necessary (and often otherwise unavailable) space to be angry and to express negative emotions as well as to do the work of personal and institutional grieving, particularly in relation to shifts in the configuration of academic labour.

As such, social media can operate as both crowd-sourced career counselling as well as a bit of therapy, opening up a unique space where academics across hierarchies and spaces in the university can meet one another, relate to one another's experiences, and find some comfort. As Deborah Lupton $(2014,13)$ found in her survey of academic social media use, academics report using social media not only to develop such networks but also because of "feeling better connected to other academics." In the academic Twitter community, crowdsourcing functions as a form of connective tissue. From sharing references and tips for academic success to solidarity 
during the hard times, Twitter becomes an important source for support. Veletsianos (2016) refers to this as networks of disclosure in which individuals disclose personal information, which elicits support from the community. This also speaks to the feelings of care and belonging that Stewart (2016) deems a central feature to the cohesiveness of academic Twitter. The crowdsourcing, care, and feelings of belonging become what Papacharissi $(2015,23)$ identified as "affective feedback loops that generate and reproduce affective patterns of relating to others that are further reproduced as affect", thus creating a space that is shot through with meaning, personal and social value, and a range of emotions.

\section{3. "Academic Twitter"}

"Academic Twitter" is an informal term that refers to the loose community of academics and scholars who use Twitter as part of their academic identities, and recent scholarship (Veletsianos 2012; McMillan Cottom 2015a; Fransman 2013; Stewart 2015; Rambukkana et al. 2015; Daniels and Thistlewaite 2016; singh 2017) has begun to explore this community. Like Mewburn and Thomson, Stewart $(2015,11)$ found that scholars cultivate a type of reputation and influence on Twitter that is different from traditional academia and that they are "engaged in curating and contributing resources to a broader 'conversation' in their field or area of interest rather than merely promoting themselves or their work." Stewart $(2016,61)$ suggests that "academic Twitter" should be best thought of as a "phenomenon in which oral and literate traditions - and audience expectations - are collapsed, creating a public that operates on very different terms from those of academia."

As singh $(2017,6)$ suggests, academics have taken to Twitter because they have found it "fertile for creating and nourishing both ideas and community." Such "fertility" has to do in part with the type of conversation that the platform encourages and the way that academics have adapted this platform. Singh writes: "Despite, or maybe because of, the 140- character limit for each tweet and the ever-changing nature of the platform, people have managed to use and work around the affordances of Twitter in ways that have allowed for many levels of interaction, collaboration, and production of work" (singh 2017, 7). As Stewart $(2016,73)$ found, it is not simply that the platform affords interaction or collaboration but that Twitter "enables a performative register that academia does not; a personal/professional voice that is distinct from more formal, depersonalized scholarly communications."

Stewart calls this a "hyperpersonal" $(2016,75)$ form of communication. On Twitter, such hyperpersonal communication, marked by informal, playful, or humorous speech, is rewarded with more engagement - often in the form of "favorites" and "retweets." Such favorites and retweets are themselves a form of affective communication. Additionally, the platform allows for the creation of "hashtags," which, as Stewart $(2016,80)$ writes, "can be a way to galvanize widely-distributed communities around issues of shared advocacy." As such, hashtags can also be deeply imbued with emotion, which is then activated and circulated through the mechanisms of the platform.

In addition to facilitating new types and tenors of conversation among academics, McPherson, Budge, and Lemon (2015) emphasize how Twitter affords informal learning, highlighting some of the ways in which academic development takes place within the informal conversations on Twitter, which also help bypass the more traditional academic hierarchies. Thereby, Twitter is actively challenging academic norms, and as singh $(2017,66)$ writes, "Scholars seem to take to social media because it pushes against the very rigidity and constraints of traditional scholarly practices." 
However, inasmuch as Twitter may be challenging scholarly norms and drawing the personal, informal, and emotional into the professional, Twitter is also a platform that mimics and capitalizes on a set of larger broader logics that are reshaping the University. As Gregory (2017) has suggested, academics are "increasingly working in and through a set of logics of the digital - and these are logics that privilege connectivity, speed, on-demand access, convenience, choice, personal and personalized 'experience,' affectivity, as well as privilege the capacity for metrics and measurement." In many ways, academic Twitter can be seen as a creature of these entangled logics, giving rise to a set of complicated "digital labour" issues for academics, which in turn muddy the emotional waters of the platform.

Such digital labour issues are directly related to casualization, deprofessionalization, and precarity in higher education. Beyond the desire and need to locate and cultivate community, academics are drawn to online spaces in order to try to contribute to ongoing discussions and distinguish themselves among the crowd. This work entails demands to be "always on," to be perceived as continually "productive," and to be ready to "pivot" in order to embrace opportunity. In the digital factory of social media, this demand can begin to feel like a 24/7 need to be connected, and it can reshape "disconnection" as "FOMO" or the "fear of missing out." This fear can become self-justifying when digital connection is necessary to pay the bills or generate the possibility of future employment.

Such "hope labor" (Kuehn and Corrigan 2013, 9), where one works for experience or exposure rather than compensation, "in the hope that future employment opportunities may follow," informs the background of much of the production of community on Twitter. This is not to suggest that such community is not meaningful, but to make the point that as scholars take to "academic Twitter," issues of career trajectory and future employment are plainly present. For many graduate students, adjuncts, and contingent faculty, social media presences are created in the hopes of joining the academic community - something not guaranteed by a degree or even by the securing of work in the university.

Furthermore, the rise of "academic Twitter" cannot be separated out from the rise of the power of metrics, as well as increased surveillance of workers, in higher education. Twitter is fundamentally a metrics-based platform, tracking tweets, tweet engagement, followers, favorites, and lists, and it offers a whole suite of analytics to individual users. These metrics inform a larger audit culture in academia, whereas Carrigan (2016) has suggested, "we rely on these metrics as cyphers for quality: ways of assessing in lieu of evaluation, assessing others and assessing ourselves." As Moorish (2016) has written, such metrics may even give rise to a new form of "Trump academic," whose motivations "coalesce around work which pleases governments, university managers and students. Now, even a permanent contract cannot guarantee the indulgence of ethical behaviour and academic freedom."

Even when Twitter is used in good faith by academics to participate in conversation, offer support and advice, and to share knowledge and resources, such metrics are nonetheless accrued. In this vein, we see that some academic users of Twitter become what Terri Senft (2008) and Alice Marwick (2013) call "microcelebrities." Microcelebrity refers to a "self-presentation technique in which people view themselves as a public persona to be consumed by others, use strategic intimacy to appeal to followers, and regard their audience as fans" (Marwick 2015, 332). Microcelebrity trades in "affective capital engendered and commodified by various social and new media platforms where identity and brand are merged and measured in likes, shares, follows, comments and so on" (McMillan Cottom 2015a). Such microcelebrity can be 
both a blessing and a curse for academics: as audiences grow, publicity can bring opportunity as well as negative attention, harassment, and trolling. If digital media presences, brands, and microcelebrity contribute to the development of academic capitalism, it does so on the backs of individuals who must now individually negotiate the online crowd. Such negotiations are, of course, not evenly distributed. Racism and sexism are daily experiences online, taking the form of comments, aggressions, and threats. Hate messages and death threats are also targeted at academics who express controversial ideas or who take up explicitly political positions. The very experience of building a media presence is shot through with the politics of race and gender (McMillan Cottom 2015a).

The embrace of social media also brings with it the possibilities for surveilling and monitoring individuals. Such surveillance can take overt forms, as University public relations teams monitor faculty and student accounts, as well as less overt forms of "self-surveillance." Social media users can find themselves engaged in what Andrejevic (2002) called "lateral surveillance" or a type of peer monitoring: surveillance that has moved from the realm of law enforcement to everyday life. Twitter, in particular, allows for a "social surveillance" (Tokunaga 2011; Marwick 2012) in which we can monitor what our friends, peers, and connections are doing through social media and in "real time." Twitter's ephemeral nature can create a false sense of security where we imagine what is posted is quickly swept away in the Twitter stream. Such ephemeralness can mask the very real "publicness" and permanence of Tweets, as well as mask the range of actors (such as institutional administrators, institutional benefactors, colleagues, and students) who may encounter this writing. Furthermore, the issue of surveillance brings with it long histories of racism, racial formation (Browne 2015), and gender discrimination and social media continues to exacerbate the question of who is surveilled and whose speech or actions are scrutinized and why.

\section{Anger and Twitter}

As Bloch $(2012,127)$ writes, "Academia is an organization that generates strong feelings of shame, bitterness, and anger," but the display of anger within academia is relatively taboo or, as Bloch suggests, a "breach of feeling rules." Despite the prevalence of negative emotions in academic work, the narrative of the university as a space of rational and objective pursuit of knowledge structures those "feeling rules." However, as we can see from the discussion of Twitter, online platforms can be marked and defined by a different set of rules and norms. Twitter, in particular, is a space where not only do professional and personal roles and identities blur but where the platform encourages and rewards personal, informal, and emotional contributions and interactions. As academics come to work in and through the platform, professional "feeling rules" are being redefined in relation to the platform's affordances.

While Twitter can facilitate long-term, sustained relationships and ongoing debates and discussions, the platform is designed for short (140 characters) bursts of communication and for instantaneous and rapid response from both "followers" and those outside one's "follower" network. Communication on Twitter can also move very quickly, as a single tweet can not only be responded to but also "favorited" and/or "retweeted," or shared by others, into their timeline. The brevity, informality, speed, and reach of discussions can make Twitter an interesting, exciting, and diverse space. However, it can also be a recipe for almost immediate (and public) miscommunication, with the speed of the platform potentially collapsing any chance for clari- 
fication, dialogue, or debate. The limitations and immediacy of the platform can stymie what Bady (2015) has called "generous readers" and Twitter conversations can easily spiral into large-scale "crises" of communication, without much hope of recuperation of mutual ground among participants.

Furthermore, Twitter has gained a reputation for being particularly "toxic" (Rosenbaum 2016; Carrigan 2017). The platform has given safe haven to trolls, abusers, and white supremacists. For example, the platform now operates as a megaphone for the current U.S. president, Donald Trump, who has used it to berate fellow politicians and target private citizens of the United States (Paquette 2016). The language of "toxicity" has also been taken up to castigate women of colour online. Here debates about the "righteousness of other feminists" (Goldberg 2014) have blurred in larger condemnations about the ways in which diverse groups of activists have used Twitter as a platform to debate, organize, or theorize. We suggest that while Twitter as a platform has several design issues that can and do facilitate abuse, the language of "toxicity" can mask a racialized critique of the diversity of the platform.

But Twitter also provides a space for academics to channel that anger towards finding strength in community. For example, when writing about race and tenure in the academy, Matthew notes that, "when faculty of color rightly fear that their experience with institutional racism is singular rather than part of a broader pattern, social media provide a space to find affirmation and solidarity" $(2016,242)$. So, despite its pitfalls, a key strength of "academic Twitter" is its diversity, its plurality of voices across academic hierarchies, and its ability to bring to light otherwise untenable conversations, particularly about race, gender, discrimination and labour issues in the university. "Academic Twitter" forms, in many ways, a backchannel to academic conversations that are not often welcomed or given a home in the brick-and-mortar university.

Given the platform's affordances and the ways in which academics are taking to Twitter, it is reasonable to expect that anger will emerge in and through interactions. As Stewart $(2016,78)$ suggests, Twitter is increasingly being used as a "tactical platform": individuals and groups take advantage of the reach of the platform, particularly through the use of hashtags, "which enable widely-distributed individuals to organize and galvanize around issues of common interest, political advocacy, or defense of what may be culturally perceived as threatened territory." Stewart goes on to suggest that a form of "call-out culture" has also grown up alongside of this tactical use of the platform. "Calling-out" refers to the process by which tweets are shared and retweeted on a mass scale, specifically to draw negative attention to those tweets. Stewart $(2016,82)$ writes: "The rise of call-out culture thrusts academic Twitter into the messy business of being truly open to multiple publics at once, and forces scholars to navigate the cognitive dissonance between orality-based expectations of sociality and print-based interpretations of speech." Conversely, calling-out can also draw attention to important social justice issues and to amplify the voices of marginalized or vulnerable populations.

However, not all anger engendered by Twitter takes the same trajectories, and below we examine two different cases of where anger and other negative emotions have erupted on Twitter, to examine how these emotions function and to explore their social effects. As the sociologist Mary Holmes (2004) has shown in her work on anger and political life, anger plays a complex role in the unfolding of sociopolitical life, both motivating activity and fuelling conflict. In the case of Twitter, we also see that negative emotions play a vital, often fundamental, role in determining how ongoing 
events in higher education are discussed, engaged, and experienced at both a personal and institutional level.

\section{Passionate Tweeting}

As Marwick and boyd $(2010,129)$ suggest, Twitter can inspire a need to tweet "passionately" to a networked audience, yet Twitter, as well as other social media platforms, suffer from what is known as context collapse, or "the flattening of multiple audiences into one." As Marwick and boyd (2010) suggest, context collapse can create tension for social media users who must attempt to strike a balance between perceived "authenticity" and "inauthenticity" while successfully addressing the ideal networked public. In the context of academic Twitter, additional tensions are added as individuals attempt to strike a balance between disseminating research, writing, and new ideas and being seen as engaging in "self-promotion" (Stewart 2016, 77). Additionally, as academics gain additional followers or become "microcelebrities", their profiles are subject to increasing public awareness and public scrutiny. While Twitter users may feel they are tweeting to a limited audience of peers, such publicness brings with it the possibility of backlash from both the user's audience, as well as from those who take tweets, as a form of public writing, out of context. In this case, "passionate" Tweeting, which may be emotionally charged, hyper-personal, and even controversial, can spiral beyond the confines of Twitter, fuelling an increase in negative emotions, hostility, and substantive repercussions. To highlight how this can play out on Twitter, we look to three cases where academics have suffered a "backlash" from public audiences.

In July 2014, Israel launched a military attack on Gaza and Steven Salaita, who is of part-Palestinian descent, tweeted passionately and angrily against Israel's offensive. At the time of his tweets, Salaita was between jobs, having resigned from Virginia Tech in preparation for a job at the University of Illinois at Urbana Champaign (UIUC). Salaita's tweets garnered the attention of University donors, whose objections, combined with the fact that Salaita's position at UIUC had not yet passed board approval (a routine process that is usually considered a formality), made the university decide to rescind their job offer. This was an unprecedented step and caused public outcry amongst Salaita's supporters who called for his reinstatement and for strong consideration of academic freedom. This was displayed on Twitter using a number of hashtags including \#supportsalaita, \#uistudents4salaita, \#ReinstateSalaita, \#Salaita, \#UIStudents4Salaita, \#BoycottUIUC and \#RestoreAcademicFreedom. Hashtags like these provide a way to organize content and networked publics around particular topics or occurrences (Papacharissi 2015).

While the Salaita case shocked a number of faculty, both tenured and untenured, the larger implications of this case suggested that the protections of tenure may be limited online, while clearly sending the message to non-tenured and adjunct faculty to toe the line. Salaita's tweets were evaluated on the basis of a lack of "civility", both by media outlets (Mackey 2014) and by Phyllis Wise (Des Garennes 2014) then Chancellor of UIUC, to validate the decision to dismiss him. This reduction of anger, passion, or outrage to a measure of "civility" allows institutions to control what is deemed appropriate academic speech based on an expectation of civil discourse, the definition of which is set by the institution rather than the context (Cloud 2015, 15).

Salaita subsequently sued and then settled with the University, stating "this settlement is a vindication for me, but more importantly, it is a victory for academic freedom and the First Amendment" (Svoboda 2015). However, this case has had lasting impact on the academy in terms of starting and continuing the conversation about 
boundaries of academic freedom in the context of social media (e.g.: McNeill and Zuern 2015; Cloud 2015; Greenhow and Gleason 2015; Moshman and Edler 2015; Macek 2015). Overall, the case has shown up the governance structure within some institutions and has suggested that institutional responses to social media "crises" are highly context dependent.

Saida Grundy and Zandria Robinson, both sociologists, found themselves in similar situations because of tweets that were critical of the structural racism that creates obstacles for African Americans in the US. In both cases there was angry backlash, led mostly by conservative groups and media outlets, claiming bigotry and calling for their respective institutions to take action. Grundy's tweets came just as she was about to start a new job at Boston University, which, at first, claimed she was within her rights to make these comments on her personal Twitter account. However, after pressure from alumni and others, Boston University released a statement saying that while they did not condone racism or bigotry, they still supported Grundy's freedom of speech (Brown 2015). Grundy (2015) also released a statement regretting the way she addressed the issue. Ultimately, this incident did not affect her position at the university. When the backlash started, other academics rushed to support Grundy through hashtags like \#SaidaGrundy, \#ISupportSaida, and \#IStandWithSaida, and like the Salaita case, spawned blog posts and articles discussing academic freedom.

In Salaita's case, public outcry worked towards pressuring the institution to de-hire him, and the support - both on Twitter and otherwise - did not help to reinstate him. While the attention the case garnered made it possible for Salaita to embark on a fairly successful public speaking stint, it was at the cost of a tenure track academic career. In Grundy's case, public outcry forced her institution to make a statement criticizing her tweets, but they still supported her position and did not fire her. In both these cases, hashtags formed a node of anger and activism, bringing disparate groups of people together in their support of Salaita and Grundy, and academic freedom. Not only did the use of the hashtags on Twitter signify support to the people involved, it also encouraged others to participate, affording an "always-on, ambient" network that can be quickly mobilized, especially through prominent network nodes (Papacharissi 2015, 37).

In the case of Zandria Robinson, whose tweets also addressed race, the University of Memphis itself took to Twitter to respond. The university tweeted that Robinson was no longer employed by the university, leading people to believe that Robinson had lost her job because of her tweets. This brought on a fresh wave of angry tweets in her support, before she let it be known that she had resigned prior to those tweets to pursue another job. Again, Twitter played a role in both the call for action against and in support of Robinson. In their statement, her institution (Rhodes College) showed a surprising level of understanding of how social media limits the transmission of particular ideas and how that did not, for them, reflect negatively on Robinson. Interestingly, there didn't seem to be specific hashtags in support of (or against) Robinson aside from \#ZandriaRobinson, although there was certainly support for her on Twitter.

Recently, there was controversy around some of George Ciccariello-Maher's tweets, who also tweeted about race, at one point calling for "white genocide" - a term propagated by white nationalists to instil fear about an unfounded conspiracy to destroy the white race. His intention to mock the white nationalist term was taken out of context, again by conservative groups, to the point that his university is now investigating the matter (Flaherty 2017). Drexel released statements that condemned Ciccariello-Maher's tweet while supporting his freedom of speech, but asserting that his 
tweets "do not represent the values of inclusion and understanding espoused by Drexel University." (Drexel University 2016.) In a longer statement, they assert that Ciccariello-Maher's tweets constitute "protected speech", but at the same time denounce them while attempting to explain that social media like Twitter "are limited in their ability to communicate satire, irony and context" (Fry and Blake 2016). At the time of this writing, Ciccariello-Maher's case is ongoing. There are still people tweeting about this case, many directly at Drexel University calling for Ciccariello-Maher to be fired. As with Robinson's case, there seem to be no specific hashtags associated with Ciccariello-Maher's case.

While the tweets we highlight are not overtly "angry" they come from a place of frustration towards racism and structural violence. Each of these academics used their platform to voice opinions based in their own research, and experiences - as a way to express their opinions while performing their role as academics and public intellectuals online. Such "passionate" tweets, however, mingle with already affectfilled environment of Twitter. This affect fuels both the backlash and the support the platform can offer. As Papacharissi $(2015,56)$ suggests affect can be "sticky", especially as online conversations swirl and can "blend emotion with opinion and drama with fact." As conservative groups rallied and mobilized their outrage and anger, media outlets took advantage of the viral nature of social media posts. Simultaneously, there was a surge of support from fellow academics coming together to protest the unfair treatment of their colleagues, bringing more attention to the issue of academic freedom and institutional responsibility towards faculty.

These events had both personal and professional repercussions and raise interesting and troubling questions about the state of academic freedom with regards to social media and academic Twitter. Veletsianos $(2016,56)$ points to a key tension, which is highlighted by cases like these: while academics may be expected to create and maintain a public presence on seemingly ephemeral spaces such as Twitter, tweets and words written online are from fleeting. They can be searched, gathered, and used out of context. In the flurry of online conversation, such words can also "stick" to an individual, who must then personally account for their use of language. These cases point to the conflicted state of public, digital, and networked academic work, which both encourages participation in communities such as Twitter, but affords little institutional protection. As Wingfield (2015) has suggested we should understand these cases as "canaries in the coalmine" of the weakening protections for academic labour.

\section{Collectivising the Anger: \#iammargaretmary}

Passionate tweeting, however, does not always result in backlash and in line with Stewart's (2016) observation that Twitter is being taken up as a tactical platform we can analyse the hashtag \#iammargaretmary as an example of collective anger that was able to bring wider attention to academic labour issues. In September of 2013, adjunct professor Margaret Mary Vojtko passed away from complications resulting from cancer treatment and a heart attack. Margaret was eighty-three years old and had taught at Duquesne University for twenty-five years, but when she passed away she had no health benefits or retirement benefits (Rhoades 2013). Vojtko had been earning adjunct wages at Duquesne (between $\$ 3,000$ and $\$ 3,500$ per course, a wage set after an effort by United Steelworkers to organize adjunct faculty), working from contract to contract and with little job security. Just prior to her death, Duquesne had failed to renew her contract. 
When details of Vojtko's death were made public in the Pittsburgh Post Gazette (Kovalik 2013), the story was quickly taken up on social media, where the news struck a nerve, particularly among academics. Currently, seventy-five percent of faculty in American universities are adjunct or contingent faculty, with an average pay of between $\$ 20,000$ and $\$ 25,000$ a year (Sanchez 2013). Seeing themselves in the story of Vojtko, the hashtag \#iammargaretmary quickly formed across Twitter and Facebook. Individuals took to the hashtag to tweet directly at the University, to call for solidarity among faculty, to call for adjunct unionization at Duquesne and other universities, and to share their personal stories. Some suggested they would never work at Duquesne, while others demanded that the Catholic University be held to moral standards. Many used to the hashtag to tweet directly to mainstream news outlet to demand they cover the story. Some suggested the hashtag was a "thread" to be read by any person considering a career in academics. Others used the hashtag along with images of themselves holding signs that read "We Are All Mary". This hashtag came to represent an outpouring of grief and anger, particularly anger at the growing disparity within administrative salaries at the University, and faculty labour conditions (Saul 2015).

While the hashtag drew clear attention to labour conditions within the contemporary university, it also touched a nerve as it kicked off a conversation about education and mobility in the United States. As Rhoades (2013) wrote, when a caseworker learned of Vojtko's death she asked, "She was a professor?" Higher education, and particularly the attainment of a PhD, has long been linked with notions of status, as well as stable employment. Vojtko's death highlighted the disjunction here, bringing to light the reality that adjunct professors are not only a part of the working class, but increasingly, part of the working poor.

While \#iammargaretmary and its subsequent discussions were full of anger, frustration, and demands for justice, the hashtag worked to mobilize individuals across university hierarchies, across universities, and outside of the University. Mainstream media outlets such as NPR, CNN, and The New York Times featured stories about Votkjo and the plight of academics. The New York Times (Kilgannon 2014) ran a subsequent story about Mary-Faith Cerasoli, an adjunct professor at Mercy College in New York, who was currently homeless. Beyond media attention, the hashtag also helped to foment support for a unionization drive at Duquesne, a move the administration opposed despite a vote in favour by faculty.

As suggested earlier, given the structural conditions of labour in the University, it is perhaps not surprising that academics are taking to new platforms to connect and mobilize. As Papacharissi $(2015,4)$ has suggested, social media can help to "activate and sustain latent ties", which in turn may give rise to a "networked public". Yet, the success of such a public is often coupled with offline work. The anger surrounding \#iammargaretmary helped fuel feelings of solidarity and encouraged offline mobilization. Furthermore, the impact of that collective anger continues as the hashtag is revisited and shared, forming an online archive that can be linked to current and future labour struggles.

\section{Conclusion}

Passionate tweets can act as catalysts for action, conversation, or censure. For individual academics tweeting in a professional capacity, there is a distinct lack of institutional support - both in terms of preparing and training academics for social media interactions and in terms of assuring support if and when anything untoward occurs. McMillan Cottom (2015b; 2017) and Grollman (2015) provide some guidelines but 
urge scholars and institutions to at least start the conversation around what academic freedom means and how institutions can protect and support their faculty, staff, and students if things go awry. On Twitter, there seems to be strength and solidarity available to academics when they participate in collective hashtags such as \#iammargaretmary, where there is access to support from the community. However, race and gender are fundamental to who is targeted or disciplined, and for what reasons. As Lê Espiritu, Puar, and Salaita $(2015,64)$ point out in their critique of the Salaita case, "it is not just that political and social speech and actions can be understood within a civil/uncivil binary but that certain bodies are constructed to simply be, a priori, uncivil."

Being academics on Twitter is deeply fraught. The already complex nature of anger and outrage online can mean that one is cultivating a personal academic "identity", but they are also participating in a broader "affective public" (Papacharissi 2015) with its own emerging rules, norms, and codes of behaviour, as well as structural racisms and biases. Online spaces are not removed from everyday politics, but rather deeply entangled and forged by them. Understanding that negative emotions play a key role here is not to suggest that academics grow wary of public participation, but rather to suggest the extent to which these spaces are political, social, and cultural lived realities. Rather than see social media as a personal project of self-marketing, we suggest that academics learn to talk about and participate in social media as a fully social endeavour, one fundamentally about social relations, their emotionality, and their possibilities - both for destruction, as well as for the creation of new worlds.

\section{References}

Andrejevic, Mark. 2002. The Work of Watching One Another: Lateral Surveillance, Risk, and Governance. Surveillance \& Society 2 (4): 479-497. Accessed September 27, 2017. https://ojs.library.queensu.ca/index.php/surveillance-and-society/article/view/3359

Apple, Michael. 2009. Understanding and Interrupting Neoliberalism and Neo-Conservatism in Education. Pedagogies: An International Journal 1 (1): 21-26.

Bady, Aaron. 2015. You Are Totally Unreliable Twitter. The New Inquiry. Accessed April 28, 2017. https://thenewinquiry.com/blog/you-are-totally-unreliable-twitter

Beetham, Helen. 2016. Employability and the Digital Future of Work. In Proceedings of the 10th International Conference on Networked Learning, edited by Susan Jane Cranmer, Nina Bonderup-Dohn, Maarten De Laat, Thomas Ryberg and Julie-Ann Sime. Accessed September 27, 2017.

http://www.networkedlearningconference.org.uk/abstracts/pdf/S2 Paper3.pdf

Bloch, Charlotte. 2012. Passion and Paranoia: Emotions and the Culture of Emotion in Academia. New York: Routledge.

Bousquet, Marc. 2008. How the University Works: Higher Education and the Low-Wage Nation. New York: New York University Press.

Bowles, Kate and Richard Hall. 2014. Wider Lessons. Music for Deckchairs. Accessed April 29, 2017. https://musicfordeckchairs.com/blog/2014/12/02/wider-lessons

Brown, Robert, A. 2015. Letter from President Brown. Boston University Office of the President. Accessed April 29, 2017. https://www.bu.edu/president/letterswritings/letters/2015/5-12

Browne, Simone. 2015. Dark Matters: On the Surveillance of Blackness. Duke University Press.

Carrigan, Mark. 2017. Social Media for Academics and the Increasing Toxicity of the Online Ecology. Accessed April 29, 2017. https://markcarrigan.net/2017/01/23/social-media-foracademics-and-the-increasing-toxicity-of-the-online-ecology

Carrigan, Mark. 2016. Social Media for Academics. London: Sage. 
Cloud, Dana L. 2015. "Civility" as a Threat to Academic Freedom. First Amendment Studies 49 (1): 13-17.

Daniels, Jessie and Polly Thistlethwaite. 2016. Being a Scholar in the Digital Era: Transforming Scholarly Practice for the Public Good. Bristol: Policy Press.

Darder, Antonia. 2012. Neoliberalism in the Academic Borderlands: An On-going Struggle for Equality and Human Rights. Educational Studies 48 (5): 412-426.

Des Garennes, Christine. 2014. Updated: Wise Explains Salaita Decision, Gets Support From Trustees. The News Gazette. Accessed April 29, 2017. http://www.newsgazette.com/news/local/2014-08-23/updated-wise-explains-salaita-decision-gets-supporttrustees.html

Drexel University. 2016. Response to Professor George Ciccariello-Maher's Tweet. Drexel Now. Accessed April 29, 2017. http://drexel.edu/now/archive/2016/December/Drexelresponse-Ciccariello-Maher

Flaherty, Colleen. 2017. Looking into Tweets. Inside Higher Ed. Accessed April 29, 2017. https://www.insidehighered.com/news/2017/04/18/documents-show-drexel-investigatingprofessors-tweets-its-unclear-whether-faculty

Flanders, Julia. 2012. Time, Labor, and 'Alternate Careers' in Digital Humanities Knowledge Work. In Debates in the Digital Humanities, edited by Matthew K. Gold, 292-308. Minneapolis: University of Minnesota Press.

Fransman, Jude. 2013. Researching Academic Literacy Practices Around Twitter: Performative Methods and Their Onto-Ethical Implications. In Literacy in the Digital University: Critical Perspectives on Learning, Scholarship and Technology, edited by Robin Goodfellow and Mary R. Lea, 27-41. Abingdon: Routledge.

Fry, John A. and M. Brian Blake. 2016. Message Regarding Academic Freedom, Freedom of Speech and the Need for Inclusivity and Respect. Drexel Now. Accessed April 29, 2017. http://drexel.edu/now/archive/2016/December/Message-to-community-on-academicfreedom-inclusivity

Gill, Rosalind. 2009. Breaking the Silence: The Hidden Injuries of Neo-Liberal Academia. In Secrecy and Silence in the Research Process: Feminist Reflections, edited by Róisín Ryan-Flood and Rosalind Gill, 228-244. Abingdon: Routledge.

Greenhow, Christine and Benjamin Gleason. 2015. The Social Scholar: Re-Interpreting Scholarship in the Shifting University. On the Horizon 23 (4): 277-284.

Gregory, Karen. 2017. The Labor of Digital Scholarship. Talk Given at University of Edinburgh. Accessed April 28, 2017.

https://ed.hosted.panopto.com/Panopto/Pages/Viewer.aspx?id=41552549-5650-4cdfbf62-05999534c270

Gregory, Karen and Joss Winn. 2016. Marx, Engels and the Critique of Academic Labor. Workplace: A Journal for Academic Labor 28: 1-8. Accessed September 27, 2017. http://ices.library.ubc.ca/index.php/workplace/article/view/186209

Grollman, Eric A. 2015. How to Support a Scholar Who Has Come Under Attack. Conditionally Accepted. Accessed April 29, 2017. https://conditionallyaccepted.com/2015/07/09/attack

Grundy, Saida. 2015. Letter to the Editor: Openness, Nuance Needed in Conversations on Race. The Daily Free Press. Accessed April 29, 2017. http://dailyfreepress.com/2015/05/12/letter-to-the-editor-openness-nuance-needed-inconversations-on-race

Hall, Richard. 2016. Writing About Academic Labour. Richard Hall's Space. Accessed April 28, 2017. http://www.richard-hall.org/2016/10/03/writing-about-academic-labour

Hall, Richard. 2014. On the University as Anxiety Machine. Richard Hall's Space. Accessed April 28, 2017. http://www.richard-hall.org/2014/03/19/on-the-university-as-anxietymachine

Hearn, Alison. 2010. Structuring Feeling: Web 2.0, Online Ranking and Rating, and the Digital 'Reputation' Economy. ephemera: theory \& politics in organization 10 (3/4): 421-438. 
Holmes, Mary. 2004. Feeling Beyond Rules: Politicizing the Sociology of Emotion and Anger in Feminist Politics. European Journal of Social Theory 7 (2): 209-227.

Jordan, Katy. 2016. Digital Scholarship and the Social Networking Site: How Academics Conceptualise Their Networks on Academic Social Networking Sites and Twitter. Selected Papers in Internet Research, Association of Internet Researchers. Accessed September 27, 2017. http://oro.open.ac.uk/46730

Jordan, Katy. 2014. Academics and Their Online Networks: Exploring the Role of Academic Social Networking Sites. First Monday 19 (11). Accessed September 27, 2017. http://firstmonday.org/ojs/index.php/fm/article/view/4937/4159

Kalayji, Lisa. 2017. On Authenticity in Academic Communities, or, Why I Don't Talk to Professors at Conferences. Accessed April 28, 2017. https://lisakalayji.wordpress.com/2017/04/15/on-authenticity-in-academic-communities-orwhy-i-dont-talk-to-professors-at-conferences

Kilgannon, Corey. 2014. Without Tenure or a Home. The New York Times. Accessed April 29, 2017. https://www.nytimes.com/2014/03/30/nyregion/without-tenure-or-ahome.html?smid=tw-share\& $r=0$

Kuehn, Kathleen and Thomas F. Corrigan. 2013. Hope Labor: The Role of Employment Prospects in Online Social Production. The Political Economy of Communication 1 (1): 9-25.

Lê Espiritu, Evyn, Jasbir K. Puar and Steven Salaita. 2015. Civility, Academic Freedom, and the Project of Decolonization: A Conversation with Steven Salaita. Qui Parle: Critical Humanities and Social Sciences 24 (1): 63-88.

Lupton, Deborah. 2014. 'Feeling Better Connected': Academics' Use of Social Media. University of Canberra News and Media Research Center. Accessed April 27, 2017. http://apo.org.au/node/53908

Macek, Steve. 2015. The Perilous State of Academic Freedom in the Twenty-First Century. First Amendment Studies 49 (1): 1-4.

Mackey, Robert. 2014. Professor's Angry Tweets on Gaza Cost Him a Job. The New York Times. Accessed April 29, 2017.

https://www.nytimes.com/2014/09/13/world/middleeast/professors-angry-tweets-on-gazacost-him-a-job.html

Marwick, Alice E. 2015. You May Know Me From YouTube: (Micro)-Celebrity in Social Media. In A Companion to Celebrity, edited by Sean Redmond and P. David Marshall, 333349. Chichester: Wiley Blackwell.

Marwick, Alice E. 2013. Status Update: Celebrity, Publicity, and Branding in the Social Media Age. Yale: Yale University Press.

Marwick, Alice E. 2012. The Public Domain: Surveillance in Everyday Life. Surveillance \& Society 9 (4): 378-393. Accessed September 27, 2017. https://ojs.library.queensu.ca/index.php/surveillance-and-society/article/view/pub dom

Marwick, Alice E. and danah boyd. 2010. I Tweet Honestly, I Tweet Passionately: Twitter Users, Context Collapse, and the Imagined Audience. New Media \& Society 13 (1): 114133.

Matthew, Patricia A. 2016. Written/Unwritten: Diversity and the Hidden Truths of Tenure. Chapel Hill: University of North Carolina Press.

McCarthy, Cameron. 2011. Afterword: The Unmaking of Education in the Age of Globalization, Neoliberalism, and Information. In Cognitive Capitalism, Education and Digital Labor, edited by Michael A. Peters and Ergin Bulut, 301-321. New York: Peter Lang.

McMillan Cottom, Tressie. 2015a. "Who Do You Think You Are?": When Marginality Meets Academic Microcelebrity. Ada: A Journal of Gender, New Media, and Technology 7. Accessed April 28, 2017. http://dx.doi.org/10.7264/N3319T5T

McMillan Cottom, Tressie. 2015b. Everything but the Burden: Publics, Public Scholarship, and Institutions. Accessed April 29, 2017. https://tressiemc.com/uncategorized/everythingbut-the-burden-publics-public-scholarship-and-institutions 
McMillan Cottom, Tressie. 2017. Academic Outrage: When the Culture Wars Go Digital. Accessed July 10, 2017. https://tressiemc.com/essays-2/academic-outrage-when-theculture-wars-go-digital

McNeill, Laurie and John David Zuern. 2015. Online Lives 2.0: Introduction. Biography 38 (2): v-xlvi. Accessed April 30, 2017. https://muse.jhu.edu/article/589981

McPherson, Megan, Kylie Budge and Narelle Lemon. 2015. New Practices in Doing Academic Development: Twitter as an Informal Learning Space. International Journal for Academic Development 20 (2): 126-136.

Mewburn, Inger. 2011. Troubling Talk: Assembling the PhD Candidate. Studies in Continuing Education 33 (3): 321-332.

Mewburn, Inger and Pat Thomson. 2013. Why Do Academics Blog? An Analysis of Audiences, Purposes and Challenges. Studies in Higher Education 38 (8): 1105-1119.

Moorish, Liz. 2016. The Rise of the Trump Academic. The Sociological Review. Accessed April 29, 2017. https://www.thesociologicalreview.com/blog/the-rise-of-the-trumpacademic.html

Moshman, David and Frank Edler. 2015. Civility and Academic Freedom After Salaita. AAUP Journal of Academic Freedom 6: 1-13.

Mountz, Alison, Anne Bonds, Becky Mansfield, Jenna Loyd, Jennifer Hyndman, Margaret Walton-Roberts, Ranu Basu, Risa Whitson, Roberta Hawkins, Trina Hamilton and Winifred Curran. 2015. For Slow Scholarship: A Feminist Politics of Resistance Through Collective Action in the Neoliberal University. ACME: An International Journal for Critical Geographies 14 (4): 1235-1259. Accessed April 28, 2017. https://ojs.unbc.ca/index.php/acme/article/view/1058

Newfield, Christopher. 2016. The Great Mistake: How We Wretched Public Universities and How We Can Fix Them. Baltimore: Johns Hopkins University Press.

Papacharissi, Zizi. 2015. Affective Publics: Sentiment, Technology, and Politics. New York: Oxford University Press.

Papacharissi, Zizi. 2013. On Networked Publics and Private Spheres in Social Media. In The Social Media Handbook, edited by Jeremy Hunsinger and Theresa Senft, 144-158. New York: Routledge.

Paquette, Danielle. 2016. Donald Trump Insulted a Union Leader on Twitter. Then the Phone Started to Ring. Washington Post. Accessed April 28, 2017.

https://www.washingtonpost.com/news/wonk/wp/2016/12/07/donald-trump-retaliatedagainst-a-union-leader-on-twitter-then-his-phone-started-to-ring/?utm term=.ab4af09ff27f

Pausé, Cat and Deborah Russell. 2016. Sociable Scholarship: The Use of Social Media in the 21st Century Academy. Journal of Applied Social Theory 1 (1): 5-25.

Poritz, Jonathan and Jonathan Rees. 2016. Education Is Not an App: The Future of University Teaching in the Internet Age. New York: Routledge.

Rambukkana, Nathan. 2015. Introduction. In Hashtag Publics: The Power and Politics of Discursive Networks, edited by Nathan Rambukkana, 1-10. New York: Peter Lang.

Readings, Bill. 1996. The University in Ruins. Cambridge: Harvard University Press.

Rhoades, Gary. 2013. Adjunct Professors Are the New Working Poor. CNN. Accessed April 28, 2017. http://edition.cnn.com/2013/09/24/opinion/rhoades-adjunct-faculty

Rosenbaum, Steven. 2016. Is Twitter Toxic? Can Social Media Be Tamed? Forbes. Accessed April 27, 2017. https://www.forbes.com/sites/stevenrosenbaum/2016/09/09/istwitter-toxic-can-social-media-be-tamed/\#65bb115215a6

Ross, Andrew. 2010. The Corporate Analogy Unravels. The Chronicle of Higher Education. Accessed April 27, 2017. http://www.chronicle.com/article/Farewell-to-theCorporate/124919

Sanchez, Claudio. 2013. The Sad Death of an Adjunct Professor Sparks a Labor Debate. NPR. Accessed April 27, 2017. http://www.npr.org/2013/09/22/224946206/adjunctprofessor-dies-destitute-then-sparks-debate 
Saul, Stephanie. 2015. Salaries of Private College Presidents Continue to Rise, Chronicle Survey Finds. New York Times. Accessed September 27, 2017. https://www.nytimes.com/2015/12/07/us/salaries-of-private-college-presidents-continueto-rise-survey-finds.html

Senft, Theresa. 2008. Camgirls, Community and Celebrity in the Age of Social Networks. New York: Peter Lang.

Singh, Sava Saheli. 2015. Hashtagging \#HigherEd. In Hashtag Publics: The Power and Politics of Discursive Networks, edited by Nathan Rambukkana, 267-277. New York: Peter Lang.

singh, sava saheli. 2017. Academic Twitter: Pushing the Boundaries of Traditional Scholarship. PhD Dissertation. New York: New York University.

Slaughter, Sheila and Gary Rhoades. 2004. Academic Capitalism and the New Economy: Markets, State, and Higher Education. Baltimore: John Hopkins University Press.

Slaughter, Sheila and Gary Rhoades. 2000. The Neo-Liberal University. New Labor Forum 6: 73-79.

Stewart, Bonnie. 2016. Collapsed Publics: Orality, Literacy, and Vulnerability in Academic Twitter. Journal of Applied Social Theory 1 (1). Accessed April 27, 2017. http://socialtheoryapplied.com/journal/jast/article/view/33/9

Stewart, Bonnie. 2015. Open to Influence: What Counts as Academic Influence in Scholarly Networked Twitter Participation. Learning, Media and Technology. Special Issue: Critical Approaches to Open Education 40 (3): 1-23.

Svoboda, Abigale. 2015. UI Settles with Salaita. The Daily Illini. Accessed April 29, 2017. http://dailyillini.com/news/2015/12/09/ui-settles-with-salaita

Terranova, Tiziana. 2000. Free Labor: Producing Culture for the Digital Economy. Social Text 18 (2): 33-58.

Tokunaga, Robert S. 2011. Social Networking Site or Social Surveillance Site? Understanding the Use of Interpersonal Electronic Surveillance in Romantic Relationships. Computers in Human Behavior 27 (2): 705-713.

Veletsianos, George. 2016. Social Media in Academia: Networked Scholars. New York: Routledge.

Veletsianos, George. 2012. Higher Education Scholars' Participation and Practices on Twitter. Journal of Computer Assisted Learning 28 (4): 336-349.

Washburn, Jennifer. 2003. University, Inc.: The Corporate Corruption of Higher Education. New York: Basic Books.

Watters, Audrey. 2016. Education Technology and the Promise of "Open" and "Free." Accessed June 29, 2017. http://hackeducation.com/2016/12/07/top-ed-tech-trends-free-open

Weller, Martin. 2011. The Digital Scholar: How Technology Is Transforming Scholarly Practice. London: Bloomsbury.

Willinsky, John. 2010. Open Access and Academic Reputation. Annals of Library and Information Studies 57 (3): 296-302.

Wingfield, Adia H. 2015. Canaries in the Coal Mine? Saida Grundy, Zandria Robinson, and Why Calls for Their Firing Are a Problem for Everyone. Work in Progress. Accessed April 30, 2017. https://workinprogress.oowsection.org/2015/07/08/canaries-in-the-coal-minesaida-grundy-zandria-robinson-and-why-calls-for-their-firing-are-a-problem-for-everyone

Winn, Joss. 2016. Against Academic Identity. Accessed April 27, 2017. http://josswinn.org/2016/03/17/against-academic-identity

\section{About the Authors}

Karen Gregory

Karen Gregory is a Lecturer in Digital Sociology at the University of Edinburgh. She is the coeditor of the book Digital Sociologies (Policy Press, 2017). 
sava saheli singh

sava saheli singh is a Postdoctoral Fellow with the Surveillance Studies Center at Queen's University in Ontario, Canada. Her dissertation is titled "Academic Twitter: Pushing the Boundaries of Traditional Scholarship". 


\title{
Higher Education as a Gift and as a Commons
}

\author{
Andreas Wittel \\ Nottingham Trent University, Nottingham, UK, andreas.wittel@gmail.com, \\ https://www.ntu.ac.uk/staff-profiles/arts-humanities/andreas-wittel
}

\begin{abstract}
This paper takes as a starting point Lewis Hyde's $(2007, x v i)$ assertion that art is a gift and not a commodity: 'Works of art exist simultaneously in two 'economies', a market economy and a gift economy. Only one of these is essential, however: a work of art can survive without a market, but where there is no gift there is no art." I want to argue that the same claim should be made for those aspects of academic labour that refer to teaching and education. Education can survive without a market, but where there is no gift there is no education. However the gift that is part of all educational processes gets rather obscured in regimes where higher education is either a public good or a private good. In regimes of higher education as public good the gift gets obscured by the provision of a service by the state. In regimes of higher education as a private good (e.g. higher education in the UK) the gift gets even more obscured, obviously so. It is only in a third educational regime, where education is a common good (e.g. the recent rise of the free universities), that the gift character of education can properly shine. Whilst this should be celebrated, the notion of a higher education commons poses some severe challenges. The paper ends with an examination of possibilities of academic activists to rescue or even strengthen the gift-like character of education.
\end{abstract}

Keywords: Academic Labour, Higher Education, Political Economy, Gift, Commons, Labour, Alienation

\section{Introduction}

The world of work has lost its magic. It has become an increasingly dystopian place, causing unhappiness, stress, anxieties and mental illnesses among workers. Prominent sociologists such as Pierre Bourdieu (1999), Richard Sennett (1998) and André Gorz (1999) provide early accounts for such a development. Sennett is interested in the new work regimes of neoliberal capitalism and their social consequences. He describes how workers find it increasingly hard to generate meaning and identity under the conditions of a work ethic that worships change and risk and condemns routine, that equates resistance to change with failure. Lasting and trustful relationships at work and outside work are increasingly hard to maintain, loyalty to the organisation loses its value. Skill, craft, and the accumulation of experience count less than a flexible mindset that knows how to react to change and walk away from disaster. "The trick is, let nothing stick to you" (Sennett 1998, 79). The social results of these developments are fragmentation and the weakening of bonds. Trust becomes replaced with quality control and various forms of bureaucratic protocols that are supposed to secure good practice.

André Gorz describes a similar change. While work in Fordism, with all its obvious faults, had at least contributed to social cohesion and social integration, while it had given all workers a sense of usefulness and entitlement, work in post-Fordism is far more destructive for both, society at large and the individual worker.

"Fear and tremble [...] Never mind what you are paid, so long as you have a job [...] Be prepared to make any and every concession, to suffer humiliation or subjugation, 
to face competition and betrayal to get or keep a job, since those who lose their jobs lose everything" (Gorz 1999, 56).

More recently Carl Cederström and Peter Fleming (2012) confirm Gorz's account. "Dead man working" is a bleak analysis of work in a period where capitalism has failed as a political economy but succeeded to colonise life itself. Very much in line with concepts of the Italian post-operaismo school, Cederström and Fleming describe the contemporary struggles not as a battle between capital and labour, but as a struggle between capital and life. The attack of capital on life creates among workers in a wide range of occupations and hierarchical levels a feeling of non-living which affects even our dreams and destroys our sleep.

"Whether in the office, the call center, the service counter, in the creative industries, the retail show-floor or the backroom warehouse, life seems to be far away. We have always known that capitalism accumulates numerical value by subtracting social value, experienced as alienation, disenchantment, and dehumanisation. But what has now become evident is the sheer pointlessness of our daily endeavours" (Cederström and Fleming 2012, 2).

Contemporary accounts of work are very dark indeed. David Graeber (2015) observes a stark rise of "bullshit jobs" and hyper-destructive levels of bureaucratic managerialism. Barbara Czarniawska (2008) conceptualises humiliation as a "standard organizational product". Yiannis Gabriel (2012) develops a concept of organisational miasma which describes a contagious state of material, psychological and spiritual pollution in organisations that undergo sudden and traumatic transformations, a state that has dehumanising effects on all those who are part of the organisation.

While the work of academics has always been commodified as wage labour, for a long time it had not been normal work in capitalist societies in the sense that it was not perceived to be alienated work as defined by Marx (1959). In contrast to other areas of wage-based labour academics had significant control of both, the products of their labour power (education and research) and the organisation of their work routines. It was work that was highly autonomous and academics had a sense of ownership of the products of their labour. ${ }^{1}$ With the marketization of higher education and the consequent restructuring of the public university to a corporate entity the work of academics has turned into academic labour and academics became exposed to the same experiences of alienation and dehumanisation as the rest of the workforce in capitalist societies. They also became exposed to a lethal combination of digital technologies and managerial forms of bureaucratisation that not only turned values into economic value, but worse than that, turned many qualities of academic work into measureable quantities, into endless segments of de-contextualised data. ${ }^{2}$

What was once academic work is now academic labour. I do not know the origins and the history of the term, but it is obvious that it became prominent with the transformation

\footnotetext{
${ }^{1}$ Alienation is both an objective and a subjective condition. It is difficult to come up with irrefutable empirical evidence for the subjective aspects of this claim. I have not found any relevant literature from, say, the 1950 s to the 1980 s, confirming that academic work at that time was largely non-alienated. But I have also not found literature in this period claiming the opposite. Therefore, I see the lack of academic literature in this period writing about academic work and alienation as an indication, that alienation in academia was not a great concern. It has only become a concern over the last two decades.

${ }^{2}$ My observation that academic labour is now as alienated as all other labour is not meant to be understood as a defence or a romanticisation of the public university. In fact the whole point of this article is an attempt to look beyond higher education in the regime of the public university.
} 
of the public university into a corporate institution. It is no coincidence that 'Workplace: A Journal for Academic Labor', which has critically analysed and documented this transformation, published its first issue in the year 2000. Academic labour describes academic work in the capitalist university.

There is little disagreement in the literature that the transformation of the public university into a corporate institution and the transformation of academic work into academic labour is not a development to be applauded - neither for academics nor for students. The many downsides of this process are all too clear, starting with the obvious fact that students begin their adult life with the burden of a huge amount of debt which they will have to repay for years and decades to come. They have to indebt themselves so they are able to compete in a job market that is shrinking enormously due to digital technologies and automation (Brynjolfsson and McAfee 2011; Ford 2016). Perhaps the most problematic effect is the integration of education into consumer culture and transformation of an educational interaction into a service industry where students are turned into customers and teachers into facilitators. While it is impossible here to go into great detail reviewing literature that critically explores this transformation I would like to recommend in particular the books by Sheila Slaughter and Gary Rhoades (2004), Chris Newfield (2008), Andrew McGettigan (2013) and Ruth Barcan (2016) on the commodification of higher education. Marilyn Strathern (2000), David Harvie (2006), Massimo De Angelis (2007), Silvia Federici and George Caffentzis (2007), Massimo De Angelis and David Harvie (2009), Mark Fisher (2009), Morgan Adamson (2009), the edufactory collective (2009), Ros Gill (2009), Nick Couldry and Angela McRobbie (2010), and Richard Hall (2013) explore the rise of measurements and quantification, the loss of autonomy, the intensification of work and its implications for academic labourers and the educational process. Contributions in Karen Gregory's and Joss Winn's (2016) special issue study the notion of academic labour from a Marxian political economy. Last, but not least, I recommend two articles of my friends and former colleagues Eeva Berglund (2008) and Liz Morrish (2017) who have explained their decision to turn their back on academia in sad but highly insightful accounts on the objective conditions and their subjective implications of academic labourers.

This article is not a critique of academic labour. If anything it could be read as a response to this debate. It is a response that firstly ignores all aspects of academic labour that are about research and about administrative work. It focuses merely on the educational aspects of academic labour. Secondly, it does not engage with the alienating and dehumanising aspects of labour in the corporate university. Instead it looks in the opposite direction, in what I call the gift in higher education. Even in the most alienating conditions of academic labour, higher education, if it still wants to be meaningful in any way, has to be an interaction that is about gift-giving. The purpose of this contribution is to highlight an aspect of academic labour that is easy to be overlooked in the age of the capitalist university: the gift in higher education. Clearly the gift in higher education is fading. It is under attack. At the same time it is the most essential part in the interaction between teacher and student. This is one of the contradictions of the neoliberal university. We teachers are trying to defend and rescue something against all odds. Even worse, we are trying to rescue something that is being captured by capital. I am rather doubtful that the gift can be protected or even strengthened in a political economy that turns education into a commodity. Then again, what is the alternative? In my view as an academic activist a search for alternatives is the order of the day. 
This contribution explores higher education as both, a gift and a commons. The part of the gift is largely conceptual. While this part touches on some pedagogical issues, the main focus is on the political economy of gift-giving in the educational process. I have no intention to contrast the rather dystopian accounts of academic labour with a story of hope. As already indicated, the gift in higher education is in danger of being obscured in the corporate university. But a gift there is nevertheless, a gift there has to be. This raises the question: which political economy of higher education can protect or even foster the gift in higher education? While higher education as a public good clearly provides a more fertile ground for the gift than its form as a commodity, I will argue that it is the political economy of the commons that brings out the gift most clearly. However, it is not clear what higher education as a commons would look like. After all, we do not have an elaborated history of a higher education commons. Therefore, the part on higher education as a commons is largely an exercise in utopian thinking. I will analyse recent initiatives in higher education that neither belong to the public university nor to the corporate university and inspect whether they could be conceptualised as a higher education commons.

\section{The Gift}

Lewis Hyde (2007) develops an interesting and innovative approach to gift theory. He explores the gift from the perspective of art. Hyde understands art as a gift. He explains the connection between gift and art through a comparison of art with non-art.

Using the example of Silhouette Romances, a specific line of romantic novels that are mass-produced "according to a formula developed through market research" (Hyde 2007 , xv), Hyde explains their form of mass production. An agency uses surveys to decide on things such as the name of the heroine, her marital status, and the appropriate time for the hero and the heroine to get together sexually. Each book in this series has exactly the same amount of pages. Six new titles appear every month and are then sold at drugstores and various other locations. This series of romantic novels, so Hyde argues, is not perceived as art as it has been written with one intention only: for it to be sold on the market.

"It is the assumption of this book that a work of art is a gift, not a commodity. Or, to state the modern case with more precision, that works of art exist simultaneously in two 'economies', a market economy and a gift economy. Only one of these is essential, however: a work of art can survive without a market, but where there is no gift there is no art" (lbid., xvi).

For Hyde the notion of the gift refers on the one hand to the creation of the art work, to the gift or talent of the artist. But it also refers to an audience, to those who get challenged, touched, moved, inspired, or transformed by a work of art.

"A gift that cannot be given away ceases to be a gift. The spirit of a gift is kept alive by its constant donation. If this is the case, then the gift of the inner world must be accepted as gifts in the outer world if they are to obtain their vitality. Where gifts have no public currency, therefore, where the gift as a form of property is neither recognised nor honored, our inner gifts will find themselves excluded from the very commerce which is their nourishment. Or, to say the same thing from a different angle, where commerce is exclusively a traffic in merchandise, the gifted cannot enter into the giveand-take that ensures the livelihood of their spirit" (Ibid., xix).

The inner world of the gift is the inner world of the artist, the creator of the gift. The outer world refers to the recipients of the gift. While most anthropologists, starting with Marcel Mauss (1954), explore the gift from the perspective of social relations, Hyde has his starting point with the gift as an object. From this perspective of the gift as 
object he then explores its social dimensions. These social dimensions, Hyde insists, are not just the bond between the gift giver and its receiver. Ultimately they are about a community of people who circulate gifts.

The literature on the gift is long and rich. Particularly important is the work of Mauss (1954), Marshall Sahlins (1974), Annette Weiner (1992), Jacques Derrida (1994), Pierre Bourdieu (1997), Maurice Godelier (1999), Charles Eisenstein (2011) and David Graeber (2011). Concepts of the gift have been developed most of all in anthropology but also in other disciplines. I will ignore much of this huge body of work here as Hyde's approach to the gift is sufficient for the argument I am going to make later in this article.

There is much to praise about Hyde's work. In particular, I appreciate his interest in the immaterial aspects of the gift. A painting in a gallery exists obviously in a very material form, often with a frame that marks its physical space. However the gift of this painting does not travel in its material form, as the painting does not leave the gallery. The gift that the visitor of this gallery receives by being drawn to the painting is completely immaterial: a thought, a feeling, an experience, an understanding, a memory, a connection, or a vision. What the visitor of the gallery takes away will be in her body and her mind.

For Hyde the cardinal difference between gift exchange and commodity exchange is the fact that a gift establishes a bond between two people, whereas the commodity does not. The commodity might have value (in the sense of exchange value), but the gift has worth. "We do not deal in commodities when we wish to initiate or preserve ties of affection" (Hyde 2007, 85). For this reason we associate the gift with community and with obligation, whereas we associate commodities with alienation and freedom. The bond creating nature of the gift is also the reason why some gifts must be refused.

Perhaps the most important point Hyde makes about gifts is their tendency to circulate. He uses various examples to illustrate their circulation in gift communities. Scientific knowledge blossoms much more in a gift environment compared to a market environment that treats scientific knowledge as a commodity. This is also true for material gifts. They are often passed on to others. They leave the binary of give and take and travel from one person to the next. The gift increases its worth as it moves from the second to the third person. "While gifts are marked by motion and momentum at the level of the individual, gift exchange at the level of the group offers equilibrium and coherence, a kind of anarchist stability" (Hyde 2007, 97). Indeed, Hyde sees strong connections between anarchist theory and practices of gift exchange. Ultimately he understands gifts as an "anarchist property" (Ibid., 120) in that both, gift exchange and anarchism share the assumption that community appears at its best, when part of the self is not restrained but given away.

While Hyde agrees much with Mauss, the godfather of gift theory, that every gift calls for a return of the gift, his concept of "gift circulation" and the "gift community" opens up a narrow reading of reciprocity, a form of generalised reciprocity, to use a concept by Mauss. Someone in an art gallery who receives a gift will find it hard to return this gift to the artist. Instead he or she will pass on the gift in his/her community. The gift of scientific knowledge works in a similar non-binary way. The gift is returned in that it is spread or even enriched.

It is obvious where I am going with this. I want to ask if (higher) education is also a gift, similar to art. Before exploring this question in more detail, I want to share a personal experience that can be considered as an example of an educational gift. 


\section{Mayerhöfle}

I received the most important part of my academic education in a pub. I received this education in a non-university location, outside formal teaching times, and outside formal university structures. I received it in a location that is commonly associated with leisure and pleasure. I studied Empirische Kulturwissenschaft (cultural studies) in Tübingen, South-West Germany, in the 1980s and early 1990s. Having completed the BA degree, it took me four years to hand in my MA thesis and another four years to finish the doctoral dissertation. Long before I enrolled as a student, the academic staff at Cultural Studies in Tübingen had created something (a practice, a routine, a ritual, an institution) that is still ongoing. In fact these practices still exist, across cities, universities, faculties, and departments. Every Thursday late afternoon they organised a two-hour colloquium for all postgraduate students (MA students and PhD students). After the colloquium we went to the 'Mayerhöfle', a pub in the city centre not far from the School, where Mrs. Mayer kept a back room reserved for us. We always arrived at $8 \mathrm{pm}$, right after the colloquium and we were often the last ones to leave. Usually we were kicked out by Mrs. Mayer around 1am.

I had eight years of education in this pub. While I don't want to minimise the significance of the more formal education structures at the School, the informal education in the 'Mayerhöfle' on Thursday nights stands out as it was here that we postgrad students learned to properly work through the topics and ideas that were introduced to us in the colloquium. Thematically the pub visit was an extension of the colloquium, yet it had its own rules and conventions. It generated a very specific learning experience. In terms of debate and contributions the colloquium was very much dominated by our teachers. We students were often too inhibited to join the discussion. This changed in the pub. Here we students found our voice, challenging each other and our teachers. The hierarchies between teachers and students, so visible in the colloquium, became more clouded in the smoke of cigarettes and heated debates. Alcohol surely helped and so did the physical proximity in the back room. While the colloquium was interesting it was still considered to be work and duty. Learning in the colloquium was social, learning in the pub was sociable. It was joy and lust and play and life.

However, this should not be read as an idyllic portrayal of this space. It was not always joyful of course. At times it was dark and sad. Often it was overly competitive and argumentative. We students were fighting for status and for the attention of our teachers. It should also be emphasised that our teacher's out-of-contract time was not evenly distributed across all faculty. Gender played a stratifying role here. Furthermore the risks involved in developing these bonds were not evenly shared across race and gender lines. Clearly it was not paradise. But it was always meaningful. It was always connected to our desires.

Taking into account all our fears, our critical recognition of struggles for status, our awareness when we humiliated and embarrassed ourselves, we kept participating. We did not perceive this interaction as learning or being taught. This is what I did not understand at the time: our learning just happened anyway. It happened nearly unintentionally. We learned without being much aware that this was education too, just a different one.

Our teachers gave us a gift. We were given their time - their out-of-contract time. Obviously they did not get paid to spend every Thursday night with us students in the pub. Furthermore, we were given another space for learning and educational interaction. We were given a more joyful way to understand the themes of the curriculum, Freud, Marx, the Frankfurt School and French post-structuralism. We were given an appreciation for detail, thought, abstraction, and critique. 
All this is amazing in itself, but we received even more. We were given the opportunity to bond with our teachers and to take this bonding beyond the level of ideas. We bonded in various ways, not just intellectually but also emotionally. We were welcomed into the academic community of our School. In the 'Mayerhöfle' we postgrad students also bonded with each other. Many of these ties, both between us students and between us and our teachers have turned into ties for life. Without this gift from our teachers our bonds would not have been as deep and intense, they would not have lasted the way they did over time. With their time, their attention, their availability and their interaction, our teachers provided care. They created a gift-community which talked about values, ethics and politics, and which exchanged information, ideas, reflections and emotions. I doubt that I would have become an academic had I not received this gift. My teachers' gift had a profound impact on who I have become.

\section{Higher Education as a Gift}

The above example is perhaps a bit unusual in the British context and rather extreme in the context of the corporate university. What makes it unusual is the fact that the gift comes in the form of a change of the environment for education. This might obscure the more mundane aspects of the gift that are about education itself - not about the settings in which education takes place but about the content of teaching. It is these mundane aspects of education that are crucial for an understanding of its gift-like character.

This is the key argument I want to make: Higher education is a gift and not a commodity, just as art is a gift and not a commodity in Hyde's concept. Or, to be more specific and situate higher education in the edu-factories of digital capitalism: Education can exist in two economies, in a market economy and in a gift economy. However, only one of these is essential. Education can survive without a market, but where there is no gift there is no education. The gift in education is something that lies beyond economic rationality: it refers to a specific form of pedagogy. Similar to art, the gift in education refers to a gifted teacher and to a student who becomes enriched, inspired, challenged, moved, or transformed. The gift in education lies in the experience of the interaction between teacher and student. This gift can only emerge if the interaction is dialogical and mutual, if there is resonance.

Indeed, Hyde briefly refers to "teachings" as a gift, using the example of Alcoholics Anonymous (AA) rather than schoolbook lessons. These teachings are transformational gifts and they need time. The transformation is slow. It may take years before an insight has sunk in so deeply that its recipient can pass it along. Hyde writes:

The program itself is free. AA probably wouldn't be as effective $[\ldots]$ if the program was delivered through $[\ldots]$ the market [...] because the spirit behind them would be different (the voluntary aspect of getting sober would be obscured, there would be more opportunity for manipulation, and $[\ldots]$ the charging of fees for service tends to cut off the motivating force of gratitude (Hyde 2007, 57-58).

Let's inspect closer the educational gift that emerges in the interaction between student and teacher. For this I will introduce Hartmut Rosa's concept of resonance. German sociologist Rosa (2013) analyses contemporary social transformations mainly through the lens of acceleration. Rosa identifies three forms of acceleration that have changed 
the speed of modern life. The first one, technological acceleration, refers to transport technologies, communication technologies, and technologies of production. The second form is acceleration of social change, which refers to things such as cultural knowledge, social institutions, and personal relationships. The third form is the acceleration in the pace of life and a chronic lack of time: even though technological change should free up time for individuals (as we can travel, communicate and produce at ever increasing speed), our pace of life is still accelerating. These three forms and their internal connection is what Rosa calls "social acceleration". The discrepancy between technological acceleration and organisation efficiency and the acceleration of our pace of life is what Rosa defines as growth: "the average rate of growth (defined as increase of the total quantity of things produced, communicated, distances covered, etc.) exceeds the average rate of acceleration" (Ibid., 68-69). Or, a bit simplified: The more we try to save time via technological means the less time we have. However this does not mean that technological innovations are the culprit. These innovations do not make our life faster. They are rather a consequence of an experience of scarcity of time. The real culprit is capitalism, a system that turns time into money and acceleration into profit. In the logic of capital, social acceleration turns into an unavoidable compulsion.

From this perspective Rosa develops a new critique of alienation. If changes in the pace of our life occur at an ever faster rate, it becomes difficult to maintain strong feelings, convictions, and connections, social, institutional, personal, and intimate connections. What is required instead is flexibility and adaptability to change. There is no need for depth and authenticity any more. All attempts to intimately familiarise ourselves with the status quo, all attempts to create stability stand in direct contrast to the need to keep up with change. Rosa understands alienation as a loss of autonomy and self-determination, as an experience of life under the condition of frenetic acceleration. Such a concept of alienation is not based on Marx, on exploitation and injustice. It relates more to concepts of alienation developed by Frankfurt School theorists, to an instrumentalist approach towards nature (e.g. Horkheimer and Adorno in Dialectics of Enlightenment), or to a consumerist ideology (e.g. Marcuse in One-Dimensional Man). It is about a certain mode of being, about our relationships with the world, with nature, and with each other.

For Rosa (2016) the opposite of alienation is resonance. We are non-alienated when we manage to build non-instrumental, responsive, and transformative relationships. These are relationships with people, but also with nature and with art. They are not about domination, manipulation and control. Instead they are about a form of interaction that is based on mutuality, on the dialogical nature of listening and answering. Relationships resonate, when our interactions are important and meaningful, when we are touched and affected by them. We travel to the sea because the sea can speak to us, because we become transformed by our interaction with the sea. We listen to a live concert because we want to be affected and transformed by this experience. Resonance, Rosa insists, does not mean a harmonious relationship. Complete harmony does not generate dialogue and resonance. Resonance is as much about dissonance, about discerning difference. Thus disagreement, even conflict, is one important ingredient of resonance. But resonance also needs convergence and the building of bridges. Otherwise, transformation would be impossible.

It is fascinating how well it resonates with Hyde's take of the gift. So how can we understand higher education through the lenses of resonance and gift giving? Obviously higher education depends on the principles of interaction, dialogue, mutuality, and reciprocity. It cannot be a one-way street. Concepts of the "pure gift" (Derrida 1994), a gift that is based on altruism, do not apply here. The pure or altruistic gift does 
not create social obligations, thus does not produce any bonds. It does not produce resonance. In this respect the pure or altruistic gift is ironically rather close to monetary transactions. I am not arguing against the notion of a pure gift per se (we can see it for example in anonymous donations such as money, objects, blood, organs etc.), but in the context of higher education the notion of the pure gift does not make any sense. For this reason the pure altruistic gift is not so much about everyday life, but confined to acts of emergency, e.g. donations (blood, organs, money). The concept of education as a gift is deeply embedded in anthropological perspectives, it is about mutuality and the social. For higher education to work as a gift it has to generate feedback. No response, no resonance, no gift.

It is this insistence on resonance and the social or mutual character of gift-giving which helps to avoid a romantic portrait of higher education as gift, to avoid the rather naïve misperception that higher education always is a gift, period. It is only a gift if it is successful, if it creates resonance. A visitor of an art gallery who remains unaffected by a work of art in front of her will hardly perceive this work as a gift. The same is true in education. Students who remain unaffected by the interaction with their teacher do not receive a gift. This simple observation invites further reflections on three things, (1) on the affective nature of academic labour, (2) on the scope of non-resonance in educational relationships between teachers and students, and (3) on the political-economic understanding for such unsuccessful or non-resonant gifts.

The first point to make is that academic labour - both as research labour and educational labour - is always what Hardt and Negri (2000; 2004) define as affective labour. For them affective labour is one dimension of immaterial labour. Immaterial labour is labour that produces immaterial outcomes such ideas, concepts, knowledge, emotions and affects. Affective labour is labour that produces or modifies emotional or affective experiences in people.

"Unlike emotions, which are mental phenomena, affects refer equally to body and mind. In fact, affects, such as joy and sadness, reveal the present state of life in the entire organism, expressing a certain state of the body along with a certain mode of thinking. Affective labor, then, is labor that produces or manipulates affects [...] One can recognise affective labor, for example, in the work of legal assistants, flight attendants, and fast food workers (service with a smile). One indication of the rising importance of affective labor, at least in the dominant countries, is the tendency for employers to highlight education, attitude, character, and 'prosocial' behaviour as the primary skills employees need" (Hardt and Negri 2004, 108).

While Hardt and Negri argue convincingly that affective labour has become increasingly important for post-industrial societies in cognitive capitalism, the affective labour of the teacher is not a recent phenomenon. Teaching is never merely about the dissemination of content, but as much about pedagogy and didactics, about methods to deliver the taught content in a way that creates resonance. The relationship between a teacher and a student is as much an affective relationship as it is an intellectual relationship. The teacher fails with the delivery of the content if the student does not become affected. Something about teaching and affective labour has changed nonetheless. The last phrase in the quote by Hardt and Negri highlights the fact that affective labour is being exploited by capital. The more education ceases to be a public good and gets transformed into a commodity, the more the exploitation of affective labour matters, as its implications are devastating for the survival of the gift.

This brings us to the second point, to the scope of failed forms of gift-giving in higher education. It goes without saying that not every interaction between teachers and stu- 
dent produces resonance. In fact a large part of educational interactions could be described as non-resonant, as either teachers to not succeed in their attempts to hand a gift to students (e.g. they don't get the attention of students) or as students do not get affected, no matter how hard the teachers tries.

It is obviously impossible to find any empirical evidence for these unsuccessful forms of gift-giving in higher education. It is impossible to measure them in any meaningful way. As often, qualities of interactional processes resist quantification. Nonetheless, hardly anybody who teaches in higher education would dispute that often, in fact way too often, the attempt to resonate falls short of expectations. To put it bluntly, in the corporate university of "communicative capitalism" (Dean 2014) the notion of resonance in student-teacher-interactions might more often be the exception than the rule.

The third and last point raised by the observation that resonance in (higher) education is an objective and not something that can be taken for granted refers to the political economy. How can we think about the gift as a specific form of exchange with different forms of property regimes and different forms of governance? This is a point about the dual nature of education in the marketplace, about education that is simultaneously a gift and a commodity. With respect to resonance and gift-giving, can we compare education as a public good with education as a commodity? Is there overall less resonance when higher education has to be paid for? Does the gift get more obscured in a political economy where higher education has joined the market?

Indeed, the status and the nature of the gift in education changes according to the political-economic regime, in which higher education is provided. To be more precise, these political-economic regimes refer to different forms of property, to public property and private property. In both regimes, the public university and the commodified university the gift is obscured. In regimes of education as a public good (the public university) the gift gets obscured by the provision of a service by the state, a provision that is free for students and paid for by taxes.

In regimes of education as a private good (the commodified university) the gift gets even more obscured, obviously so. We usually don't perceive something to be a gift that we pay for. Considering that fees in higher education are not small change but lifechanging investments (and debts) it is no wonder that students demand and expect a good return for their investment. What happens when students are turned into consumers of education? Media theorist Bernard Stiegler (2010) has originated a radical critique of the ideology of consumerism. For Stiegler consumerism produces impoverished and passive subjects, it leads to a destruction of "savoir vivre with the aim of creating available purchasing power" $(2010,27)$. He describes consumerism as a form of proletarianisation. While he does not connect his critique of consumerism to the field of education, such a link is rather illuminating. Students who define themselves as consumers of education, become impoverished, as all positive aspects of learning (and the work, dedication, commitment and energy that is required to learn) are being overshadowed by an ideology that equates the purchase of education with the ownership of knowledge. After all, consumption is the opposite of production and work. The implications for teachers in the regime of commodified education have already been outlined in the first part of this article. It is safe to say that the market intensifies experiences of alienation for both, the teacher and the student. Ultimately the market will suffocate the gift-giving nature of education.

However, this does not mean that a return to the public university is the most desirable option. Nostalgia for education as a public good tends to ignore the severe critique that this regime has generated. Nearly half a century ago Pierre Bourdieu (1986) argued convincingly that class and social distinctions are predominantly upheld through 
education and higher education. Paul Willis (1977) and Randall Collins (1979) have developed similar arguments about university education as a space of privilege. For this reason, I have sympathy with the position of the edu-factory collective, which states the following:

The state university is in ruins, the mass university is in ruins, and the university as a privileged place of national culture - just like the concept of national culture itself - is in ruins. We're not suffering from nostalgia. Quite the contrary, we vindicate the university's destruction $(2009,1)$.

It is only in a third regime, in the political economy of the commons that the gift in higher education could truly shine. Obviously this does not mean that every higher education commons is per se an idyllic site. Issue of power and domination will not go away. But the common ownership of higher education does provide the most fertile ground for the gift to unfold. The last part of this article is concerned with a review of recent initiatives which might belong to a commons-based regime of higher education. It is also an exercise in utopian thinking.

\section{Higher Education as a Commons?}

A commons is usually described in political economy as a set of natural or cultural resources that can be used by all those members who are part of a commons. The members of a commons are stakeholders with an equal interest in the resources that are being shared. These resources are not privately-owned, they are owned and shared by the community of commoners. The resources are either created or administered by the commoners. They can be such different things such as land, air, water, language, knowledge, music or software. The big enemy of the commons is the market, and indeed capital. Processes of privatisation, marketization, and commodification of common property is called the enclosure of the commons.

Every commons consists of three elements: (1) people who share the commons (the commoners), (2) resources that are being shared, and (3) a form of self-organisation and normative framework that sets out how the common resources should be created, shared, maintained and developed further.

Underestimating this normative framework and the possibilities of establishing rules that are accepted by all commoners might have been the crucial weakness in Garrett Hardin's (1968) analysis of the tragedy of the commons. His arguments, which have been highly influential over several decades and which were used by neoliberal politicians to transform various commons into private property, are rooted in an assumedly unsolvable conflict between the individual interests of the commoners on the one hand and the interests of the commoning community on the other hand. For Hardin, the individual interests of the commoners tend to destroy the common good eventually. However, Hardin did not take into account that the commoners are able to communicate, establish normative frameworks and to manage possible conflicts over individual interests in a productive way.

Much of the political economy of Elinor Ostrom is dedicated to this issue. Her work, which received the Nobel prize for economics in 2009, inspects the governance of a great number of commons in the material world (land, air, water, etc.) that achieve sustainability and avoid destruction. Without getting into too much detail, Ostrom (1990) argues that a range of principles need to be in place for the commons to function 
properly. I want to mention two of these principles. Firstly, any commons in the material (natural) world has to establish a set of rules. Secondly, those who do not obey these rules have to be sanctioned by the community of commoners.

Over the last couple of decades, the commons has had an enormous revival. Surely this is a consequence of Ostrom's work, but it has also a lot do to do with the astonishing rise of the digital commons (Wittel 2013). The digital commons refers to "results of social production that are necessary for social interaction and further production, such as knowledges, languages, codes, information, affects, and so forth" (Hardt and Negri 2009, xiii). It refers to those areas of the Internet that are not built for the market. This is a new form of production, which Yochai Benkler (2006) calls variably "nonmarket production" or "social production" or "commons-based peer production". He has coined these terms to describe a new model of socio-economic production, in which large numbers of people work towards common goals without any financial compensation for those who contribute to the common good.

Massimo De Angelis (2017) makes an important distinction between endogenous and exogenous dimensions of the commons. While Ostrom is mostly concerned with the internal aspects of the commons, with the social system between commoners Marxian theorists are more interested how the social system of a commons is influenced by external factors, by capital. As will be shown this is an important distinction for an understanding of the higher education commons.

In order to explore the idea and the possibility of a higher education commons we need to start on a more basic level with the relation between education and a commons. The notion of an education commons is in itself rather problematic. If we stick to the definition above, the shared resources in an education commons would be a combination of knowledge and a form of pedagogy to gain more knowledge. However, contrary to the definition, these resources are not equally shared in a community of education commoners. In fact, they cannot be equally shared as the very process of education is fundamentally hierarchical with teachers more likely to be on the giving end (delivering knowledge and deciding on the form of pedagogy) and students more likely to be on the receiving end of the educational process. A similar problem arises with the self-organisation and the governance of an education commons. It is difficult to imagine a setting that gives students the same influence as teachers in the organisation and the normative framework in educational processes.

Still, there are numerous examples of education commons. For this we have to turn to anarchist and libertarian theories and practices of education (Suissa 2010). Most anarchist educators see an anarchist school as an embryo of a future anarchist society. Therefore, anarchist education has to embrace and reflect core anarchist values and principles such as equality, autonomy, brotherhood, solidarity, mutualism, non-coercion, generosity, and collective forms of decision-making. One of the key challenges for anarchist education is to translate these values and principles into the practicalities of the relationship between teachers and pupils. The challenge is to make this relationship as equal and non-hierarchical as possible. Therefore, famous anarchist schools such as the Escuela Moderna in Barcelona, the Ferrer School in New York, and the Walden Center in Berkeley have put their emphasis on a more spontaneous, childcentred and anti-authoritarian pedagogy, on learning-by-doing, on communal and cooperative learning. Pupils were included in decision-making processes about the curriculum and encouraged to organise their own work schedule. Rigid timetables were to be avoided, and pupils were allowed to come and go as they wished. Last, but not least, these schools insisted on a form of teaching that does not make use of grades, awards, and punishments. 
Having [...] started from the principle of solidarity and equality we are not prepared to create a new inequality. Hence in the Modern School there will be no rewards and no punishments; there will be no examinations to puff up some children with the flattering title of 'excellent', to give others the vulgar title of 'good', and to make others unhappy with a consciousness of incapacity and failure (Francisco Ferrer 1913; quoted in Suissa 2010, 79).

Another example for an education commons is the much younger tradition of homeschooling or home education communities. While homeschooling is as old as mankind, the modern homeschooling movement started in the 1960s as a reaction to state education. It is not an anarchist invention, but has received much support from anarchist educational philosophers such as Ivan Illich (1971) and John Holt (1976). More recently, however, it has been embraced by wealthy, conservative and sometimes farright groups, which is a good example to demonstrate that not every commons is per se inspired by egalitarian or even communist values. Homeschooling initiatives are a commons as they are neither organised by the market nor by the state. They are run by parent-commoners and function according to the time and labour they invest. All parents who are part of a homeschooling network (or community) invest more or less equally in such a project and have more or less equal influence in the governance of the network.

So far we can conclude that an education commons is generally a rather problematic concept due to the hierarchical relationships between teachers and students (pupils). Nevertheless we can find historical and contemporary examples of educational institutions that come very close to the political economy of a commons. What does this mean for higher education? Due to the highly specialised nature of higher education an arrangement similar to homeschooling is nearly impossible to set up.

In the last part of this article I will review two developments in higher education that are neither organised by the state nor by the market. Both developments are a response to the commodification of higher education and to the failure of the state to secure higher education as a public good. One of these developments are massive open online courses (MOOCs), or more precisely, free (as in free beer) MOOCs. The other development is the rise of Free Universities (here free stands for both, freedom and free beer).

\section{Free $M O O C s^{3}$}

Massive open online courses (MOOCs) are a child of developments in digital technologies and the social web. The first MOOCs emerged from the open-educational resources (OER) movement. They provide unlimited participation and open access via the internet. They usually consist of a mix of educational material (texts, videos, problem sets, filmed lectures) and interactive user forums. Some MOOCs, for example the University of the People (UoP), the Open Educational Resources University (OERu),

${ }^{3}$ As this article is about the gift and the commons, I will ignore those many MOOCs that are for profit and that have been built with venture capital. I will also avoid a more general discussion of MOOCs and focus specifically on issues related to the commons and the gift. For a more general critical discussion I refer to the work of James Grimmelmann (2014) and Jonathan Poritz and Jonathan Rees (2016). 
and more recently edX are non-profit organisations which provide a free education for students.

The reasons and motivations for the building of free MOOCs are complex. Most early MOOCs that came out of the Open Education movement such as the UoP were developed with the aim to widen university education with a clear focus on disadvantaged geographical areas. While this aim needs to applauded there is also legitimate criticism of a rather (post)colonial approach to bring education to Africa. But not all free MOOCs originate from a concern to fight inequality and foster development in disadvantaged areas. Some MOOCs, particularly those who are an extension of traditional universities, are ultimately promotional products for prestigious higher education institutions (Winn 2012).

Each of these institutions have slightly different arrangements and different business models, but there is also much common ground. They are all based on a fundamental distinction between learning and assessment. While the courses are free, a fee is required if students want certification.

This distinction between gratis learning and fees for assessments and certification is reflected in the educational labour that is necessary to provide for learning and for assessments. In non-profit MOOCs the educational labour that refers to teaching can be reduced to a minimum as students interact either with peers (in forums) or engage with educational resources. Thus educational labour is only needed to prepare the course and to assess students' coursework. Depending on the taught content and the design for feedback and assessment, educational labour can further be reduced through peer-reviewing and group collaboration on the one hand and automated feedback and machine grading on the other hand.

The advantages of MOOCs are undeniable. They provide an affordable alternative to university education. They also improve access to higher education, particularly in geographical regions where access to universities is difficult. For futurist Jeremy Rifkin (2014) MOOCs are the product of a radical overhaul of higher education. They deliver higher education at marginal costs. Therefore, MOOCs, so Rifkin's rather euphoric prognosis suggests, represent a transformation of higher education away from capitalist markets and toward a collaborative commons.

"The capitalist era enshrined a model of teaching designed to prepare students to be skilled industrial workers. The classroom was transformed into a microcosm of the factory. Students [...] were conditioned to follow commands, learn by repetition, and perform efficiently. The teacher was akin to a factory foreman, handing out standardized assignments that required set answers in a given time frame [...] The transition from the capitalist era to the Collaborative Age is altering the pedagogy of the classroom. The authoritarian, top-down model of instruction is beginning to give way to a more collaborative learning experience" (Rifkin 2014, 109-110).

Let's ignore for a moment the rather simplistic portrait of the traditional brick-andmortar university as a form of authoritarian and factory-like education and focus instead on his equation of MOOCs with the collaborative commons. While he is correct to point out that MOOCs have the potential to foster peer learning between students, this is not the full story. Rifkin neglects that a large part of learning in MOOCs is not collaborative but a rather lonely engagement with educational resources in the form of course material. Average completion rates for MOOC degree programmes are lower than $10 \%$, with most students dropping out in the first few weeks. The reasons for not finishing the degree vary, but a general unhappiness with traditional forms of content delivery through video lectures features rather high (Colman 2013). It is not the collaborative aspects of learning that causes students to drop out, but the lonely engagement with 
course material. Similarly the commons in MOOCs is a rather reduced commons, a commons between peer learners who can interact. It is not a commons that includes teachers, as their role is not very interactive. It lies mostly in the preparation of the course material and in the assessment of coursework.

This reduction of educational labour to pre-teaching (preparation of course material) and post-teaching (assessment of coursework) has profound implications for the notion of the gift. In these arrangements that rely on minimising interaction between students and teacher to achieve a near zero marginal cost education the gift is also minimal. After all, the whole point of MOOCs is self-directed learning. In this respect Rifkin's celebration of MOOCs' pedagogy as a stimulating, creative, collaborative and commons-based learning experience seems a bit naïve.

\section{Free and Autonomous Universities}

The second development in higher education is a rise in free and autonomous universities. This is unrelated to developments in digital technologies, it has a clear local and geographical set up. While free and autonomous universities have a long historical tradition, their recent surge is very much a response to the commodification of higher education. Free and autonomous universities are an activist approach to higher education that aims to create a non-alienated framework for teaching and learning. These institutions usually don't have formal recognition. Therefore, they are not in a position to offer certification comparable to public or private universities. Not that this is seen as a problem. On the contrary, it gives them a great amount of freedom with respect to both organisation structures and pedagogical approaches.

While organisational structures and pedagogical approaches vary between these institutions, there is a good deal of common ground. Most of them avoid or aim to reduce hierarchical structures between teachers and students. Most of them operate on the basis of collective decision-making processes. They also share much common ground with respect to pedagogy and the meaning of education. They reject a vision of university education that prepares students for work in capitalist economies. Instead they aim to transform higher education. They see education as a social and political project, as a crucial stepping stone for the creation of another society. Indeed, free and autonomous universities share most of the values of anarchist theories of education.

Over the last ten years free and autonomous universities have emerged in many geographical locations all over the world. An 'alternative education counter-cartography' lists more than 100 initiatives. ${ }^{4}$ Some of these initiatives are discussed in a reader on open education, edited by van Mourik Broekman et al. (2015).

It is hardly surprising that most of these initiatives are located in the strongholds of neoliberal capitalism, namely in the UK and the US. It is important to note that these initiatives are in different stages of development - some of them don't have a working IP address, some web sites have not been updated for a few years, some web sites are mere manifestations of protest against the corporate university, and some organise irregular public events. Indeed very few of these initiatives offer modules for students. In the UK, these are the Social Science Centre in Lincoln and the Manchester Social Science Centre. The Free University of Liverpool ran a module in 2011/12 but not since then.

${ }^{4}$ https://www.google.com/maps/d/viewer?mid=1 NqScqpNo2fAa2AEAZ3cwaK7fuXw\& II=52.06 2623365637364\%2C-1.8951416953125317\&z=8 
To understand why it is so difficult to develop sustainable institutions of autonomous higher education we need to turn our attention to labour. In stark contrast to the educational labour in MOOCs the labour of teachers who are involved in free and autonomous universities does not get reduced to assessing students work. In fact, as there is a lack of formal recognition and certification the emphasis on assessment is rather low. Educational labour here takes place predominantly in the interaction between teacher and student. While this educational labour clearly is voluntary and free labour, therefore a non-alienated form of labour, it is nonetheless intense and time-consuming. It requires a significant and sustainable enthusiasm from those who provide the educational labour. It is in these settings that the gift of higher education can shine especially bright and clear. However as this is a gift that does not generate an obligation to return the gift - similar as in art - it is fragile and vulnerable.

These free and autonomous universities are a higher education commons in the best sense. Unfortunately, they also reflect an aspect of the tragedy of the commons. However, this is a very different tragedy than the one outlined by Hardin. This is not about individuals who are part of an higher education commons and who are destroying it due to selfish behaviour. The tragedy of the higher education commons in the form of free and autonomous universities lies in the fact that these political economies are little islands that are surrounded by huge capitalist oceans. They are not destroyed from within. Tragically, they are difficult to sustain by voluntary educational labour in a capitalist world that produces an increasingly exhausted workforce. To argue with De Angelis (2017), it is not the internal social system between commoners that makes free universities so hard to sustain, but external forces such as capital. No matter how well free universities are organised as a common social system, they always have to deal with powerful forces of the external capitalist environment.

\section{Conclusion}

This article is an attempt to analyse higher education from a political economy perspective. It is a response to the academic labour debate, arguing with the work of Hyde and Rosa that higher education does not need the market economy, but does depend on a gift economy. If there is no gift there is no (higher) education, understood as a somehow transformative interaction. However, in the corporate university the gift is in danger of being obscured as the turn toward an educational consumer culture and the transformation of education as a service with student-customers and teacher-facilitators produces an environment that is dominated by a political economy of the market, where bonds between teachers and students become increasingly replaced by technologies of quality control, where qualities become replaced by measurement and quantification, where values become replaced by (economic) value. Needless to say, this is not a fertile ground for a gift economy.

To make matters worse, academic labourers who attempt to rescue the gift in higher education are confronted with the dilemma that the gift-giving interaction does not just benefit students - it takes place in an environment where all aspects of academic work (and life), including the affective relationships between teachers and students, are captured by capital. Ultimately the attempts by academic labourers to rescue the gift in education, which is what fundamentally defines our work, create an even higher level of exploitation. This is a story that is unlikely to have a good ending. For this reason I have explored the possibility of the gift in higher education in another political economy where education is neither a public good nor a commodity, but a common good. 
The result of this exploration does not provide much reason to be hopeful. While it is possible to organise education for pupils as a commons, for example via a homeschooling community of parent-commoners, such a model is impossible to replicate in the highly specialised area of higher education. Then again, new developments in higher education have recently emerged as a response to the corporate university. These initiatives are neither controlled by the state nor by the market, namely MOOCs and free and autonomous universities. Could they be conceptualised as a higher education commons?

MOOCs have an ambivalent relationship with a higher education commons. They are all about digital technologies and new forms of automation that reduce the amount of academic labour to a minimum. Therefore, there is not much of a gift in the educational process between teachers and students. However, they have the potential to create a higher education commons with respect to the community of students. They could be conceptualised as a form of commons-based peer learning. Whether this is a model of higher education that deserves to be taken seriously is beyond my judgement. However, the low percentage of completion rates does not suggest that this model will become hugely popular with students.

Free and autonomous universities are a much better fit for a higher education commons. In fact they are a perfect fit and they create a context where the gift in higher education can truly shine. This is a form of non-alienated academic work, as it is built on voluntary and non-paid labour. However, it requires a great deal of enthusiasm and a serious and time-intensive commitment from teachers. Herein lies the tragedy of the higher education commons. Free universities are sites for resistance and class struggle. They play an important role within social movements to educate for change. But they are little islands of true commoning in capitalist societies. They are unlikely to grow and pose a challenge to the model of the corporate university as it is difficult to turn them into a state of self-sustainability. For free universities to grow on a significant scale, a political economy of the commons has to emerge that goes well beyond the realm of higher education.

\section{References}

Adamson, Morgan. 2009. The Human Capital Strategy. ephemera: theory \& politics in organization 9 (4): 271-284. 19 January 2018. http://www.ephemerajournal.org/sites/default/files/9-4adamson.pdf

Barcan, Ruth. 2016. Academic Life and Labour in the New University: Hope and Other Choices. London: Routledge.

Benkler, Yochai. 2006. The Wealth of Networks. How Social Production Transforms Markets and Freedom. New Haven: Yale University Press.

Berglund, Eeva. 2008. I Wanted to Be an Academic, Not a 'Creative': Notes on Universities and the New Capitalism. ephemera: theory \& politics in organization 8 (3): 322-330. Accessed 19 January 2018. http://www.ephemerajournal.org/contribution/i-wanted-be-academic-not-creative-notes-universities-and-new-capitalism

Bourdieu, Pierre, ed. 1999. The Weight of the World: Social Suffering in Contemporary Society. Oxford: Polity Press.

Bourdieu, Pierre. 1997. Marginalia-Some Additional Notes on the Gift. In The Logic of the Gift: Toward an Ethic of Generosity, edited by Alan D. Schrift, 231-241. New York: Routledge.

Bourdieu, Pierre. 1986. Distinction: A Social Critique of the Judgement of Taste. London: Routledge. 
Brynjolfsson, Eric and Andre McAfee. 2011. Race Against the Machine: How the Digital Revolution is Accelerating Innovation, Driving Productivity, and Irreversibly Transforming Employment and the Economy. Lexington: Digital Frontier Press.

Cederström, Carl and Peter Fleming. 2012. Dead Man Working. Winchester: Zero Books.

Collins, Randall. 1979. The Credential Society: An Historical Sociology of Education and Stratification. New York: Academic Press.

Colman, Dan. 2013. MOOC Interrupted: Top 10 Reasons Our Readers Didn't Finish a Massive Open Online Course. Accessed November 22, 2017. http://www.openculture.com/2013/04/10 reasons you didnt complete a mooc.html

Couldry, Nick and Angela McRobbie. 2010. The Death of the University, English Style. Culture Machine. Accessed November 22, 2017. https://www.culturemachine.net/index.php/cm/article/view/417/429

Czarniawska, Barbara. 2008. Humiliation: A Standard Organizational Product? Critical Perspectives on Accounting 19 (7): 1034-1053.

De Angelis, Massimo. 2017. Omnia Sunt Communia: On the Commons and the Transformation to Postcapitalism. London: Zed Books.

De Angelis, Massimo. 2007. Measure, Excess and Translation: Some Notes on Cognitive Capitalism. The Commoner 12: 71-78. Accessed 19 January 2018. http://www.commoner.org.uk/12deangelis.pdf

De Angelis, Massimo and David Harvie. 2009. "Cognitive Capitalism" and the Rat Race: How Capital Measures Immaterial Labour in British Universities. Historical Materialism 17 (1): 30-33.

Dean, Jodi. 2014. Communicative Capitalism and Class Struggle. spheres: Journal for Digital Cultures 1: 1-16. Accessed 19 January 2018. http://spheres-journal.org/communicativecapitalism-and-class-struggle

Derrida, Jacques. 1994. Given Time: I. Counterfeit Money. Chicago: University of Chicago Press.

edu-factory collective, ed. 2009. Toward a Global Autonomous University. New York: Autonomedia.

Eisenstein, Charles. 2011. Sacred Economics: Money, Gift, and Society in the Age of Transition. Berkeley: North Altantic Books.

Federici, Silvia and George Caffentzis. 2007. Notes on the Edu-Factory and Cognitive Capitalism. The Commoner 12: 63-70. Accessed 19 January 2018. http://www.commoner.org.uk/12federicicaffentz.pdf

Fisher, Mark. 2009. Capitalist Realism: Is There No Alternative? Winchester: Zero Books.

Ford, Martin. 2016. The Rise of the Robots: Technology and the Threat of Mass Unemployment. London: Oneworld Publications.

Gabriel, Yiannis. 2012. Organizations in a State of Darkness: Towards a Theory of Organizational Miasma. Organization Studies 33 (9): 1137-1152.

Gill, Rosalind. 2010. Breaking the Silence: The Hidden Injuries of the Neoliberal University. In Secrecy and Silence in the Research Process: Feminist Reflections, edited by Róisín Ryan-Flood and Rosalind Gill, 228-244. London: Routledge.

Godelier, Maurice. 1999. The Enigma of the Gift. Chicago: University of Chicago Press.

Gorz, André. 1999. Reclaiming Work: Beyond the Wage-Based Society. Cambridge: Polity.

Graeber, David. 2015. The Utopia of Rules. On Technology, Stupidity, and the Secret Joys of Bureaucracy. London: Melville House.

Graeber, David. 2011. Debt: The First 5,000 Years. London: Melville House.

Gregory, Karen and Joss Winn, eds. 2016. Marx, Engels and the Critique of Academic Labor. Special Issue of Workplace: A Journal for Academic Labor 28.

Grimmelmann, James. 2014. The Merchants of MOOCs. Seton Hall Law Review 44 (4): 1035-1049.

Hall, Richard. 2013. Educational Technology and the Enclosure of Academic Labour Inside Public Higher Education. Journal for Critical Education Policy Studies 11 (3): 52-82. 
Hardin, Garrett. 1968. The Tragedy of the Commons. Science 162: 1243-1248.

Hardt, Michael. 2004. Multitude: War and Democracy in the Age of Empire. London: Penguin Books.

Hardt, Michael. 2000. Empire. Cambridge: Harvard University Press.

Hardt, Michael and Antonio Negri. 2009. Commonwealth. Harvard: Harvard University Press.

Harvie, David. 2006. Value Production and Struggle in the Classroom: Teachers within, against and Beyond Capital. Capital \& Class 30 (1): 1-32.

Holt, John. 1976. Instead of Education: Ways to Help People Do Things Better. New York: Dutton.

Hyde, Lewis. 2007. The Gift: How the Creative Spirit Transforms the World. Edinburgh: Canongate Books.

Illich, Ivan. 1971. Deschooling Society. New York: Harper \& Row.

Marx, Karl. 1959. Economic and Philosophic Manuscripts of 1844. Moscow: Progress Publishers.

Mauss, Marcel. 1954. The Gift: Forms and Functions of Exchange in Archaic Societies. Cohen \& West.

McGettigan, Andrew. 2013. The Great University Gamble: Money, Markets and the Future of Higher Education. London: Pluto Press.

Morrish, Liz. 2017. Why the Audit Culture Made Me Quit. Times Higher Education. Accessed March 2, 2017. https://www.timeshighereducation.com/features/why-audit-culture-mademe-quit

Newfield, Chris. 2008. Unmaking the Public University: The Forty-Year Assault on the Middle Class. Cambridge: Harvard University Press.

Ostrom, Elinor. 1990. Governing the Commons: The Evolution of Institutions for Collective Action. New York: Cambridge University Press.

Poritz, Jonathan and Jonathan Rees. 2016. Education Is Not an App: The Future of University Teaching in the Internet Age. London: Routledge.

Rifkin, Jeremy. 2014. The Zero Marginal Cost Society: The Internet of Things, the Collaborative Commons, and the Eclipse of Capitalism. New York: Palgrave Macmillan.

Rosa, Hartmut. 2016. Resonanz: Eine Soziologie der Weltbeziehung. Frankfurt am Main: Suhrkamp.

Rosa, Hartmut. 2013. Social Acceleration: A New Theory of Modernity. New York: Columbia University Press.

Sahlins, Marshall. 1974. Stone Age Economics. London: Tavistock Publications.

Sennett, Richard. 1998. The Corrosion of Character: The Personal Consequences of Work in the New Capitalism. New York: W. W. Norton \& Company.

Slaughter, Sheila and Gary Rhoades. 2004. Academic Capitalism and the New Economy: Markets, State, and Higher Education. Baltimore: The John Hopkins University Press.

Stiegler, Bernard. 2010. For a New Critique of Political Economy. Cambridge: Polity Press.

Strathern, Marilyn, ed. 2000. Audit Cultures: Anthropological Studies in Accountability, Ethics and the Academy. London: New York.

Suissa, Judith. 2010. Anarchism and Education: A Philosophical Perspective. Oakland: PM Press.

van Mourik Broekman, Pauline, Gary Hall, Ted Byfield, Shaun Hides and Simon Worthington. 2015. Open Education: A Study in Disruption. London: Rowman \& Littlefield.

Weiner, Annette. 1992. Inalienable Possessions: The Paradox of Keeping-While-Giving. Berkeley: University of California Press.

Willis, Paul. 1977. Learning to Labour: How Working Class Kids Get Working Class Jobs. Aldershot: Ashgate.

Winn, Joss. 2012. Open Education: From the Freedom of Things to the Freedom of People. In Towards Teaching in Public: Reshaping the Modern University, edited by Mike Neary, Howard Stevenson and Les Bell, 133-147. London: Continuum. 
Wittel, Andreas. 2013. Counter-Commodification: The Economy of Contribution in the Digital Commons. Culture and Organization 19 (4): 314-331.

\section{About the Author}

Andreas Wittel

Andreas Wittel is a Senior Lecturer at the School of Arts and Humanities, Nottingham Trent University. He is interested in the political economy of digital media, in the intersection of capitalism and the internet, and in the search for alternatives to capital. Recent book: Digital Transitions (2016, Lambert Academic Publishing). 


\title{
Metric Power and the Academic Self: Neoliberalism, Knowledge and Resistance in the British University
}

\author{
Zeena Feldman* and Marisol Sandoval** \\ *King's College London, London, UK, zeena.feldman@kcl.ac.uk \\ ${ }^{* *}$ City, University of London, London, UK, marisol.sandoval.1@city.ac.uk
}

\begin{abstract}
This article discusses the experience of being an academic in the UK in the contemporary climate of neoliberal capitalism and 'metric power' (Beer 2016). Drawing on existing literature and our own practice, the first portion of the paper explores the relationship between neoliberalism, metrics and knowledge. We then examine how neoliberal mantras and instruments impact the university's structures and processes, and reflect on consequences for the academic self. We take as a starting point the context of increasing workloads and the pressure on academics to excel in multiple roles, from 'world-leading' researchers to 'excellent' teachers and 'service providers' to professional administrators performing recruitment and (self)marketing tasks. Neoliberal academia, we suggest, promotes a meritocratic ideology of individual achievement that frames success and failure as purely personal 'achievements', which encourages a competitive ethos and chronic self-criticism. This article insists that these problems need to be understood in the context of neoliberal policy-making and the corporatisation of knowledge, including funding cuts and grant imperatives, the low status of teaching, the cynical instrumentation of university league tables, and increased institutional reliance on precarious academic labour. The article goes on to focus on responses that resist, challenge or, in some cases, compound, the problems identified in part one. Responses by dissatisfied academics range in style and approach - some decide against an academic career; others adopt a strategy of individual withdrawal within the system by trying to create and protect spaces of independence - for example, by refusing to engage beyond officially required minimums. This article argues that opportunities for positive systemic change can be found in collective efforts to oppose the status quo and to create alternatives for how academic labour is organised. Therein, solidarity can act as an instrument of opposition to the individualisation of the neoliberal academic self.
\end{abstract}

Keywords: Academic Labour, UK Academia, Metrics, Metric Culture, Higher Education Policy, Neoliberalism, Resistance, Co-operative University, Trade Unions

What does it mean to be an academic in the UK today? While the modern university has always been enmeshed in capitalist structures (see Allmer, this issue), higher education in the UK has, since the late 1970s, been thoroughly recalibrated by the 'logic' of the market (De Angelis and Harvie 2009, 6). In that time, government and university policymakers have worked to steadily align the university's legitimacy with the skills needs of industry, the competitive ethos of business and the organisational principles of managerialism. Much has been written analysing this 'neoliberal turn' in higher education, offering either systemic critiques of the modern university (e.g. De Angelis and Harvie 2009; Peters and Bulut 2011; Bulut 2011; Toscano 2011; DyerWitheford 2011) or focusing on the experiences of the individual beleaguered academic (Gornall and Salisbury 2012; Gill 2016; Ryan 2012). Yet both scales are, we believe, important to understand the state of contemporary academia. Thus, we hope to contribute to the broader project of locating the dialogue between the university, 
the academic and neoliberalism by making cogent the links between macro and micro in contemporary higher education.

To that end, this article argues that one of the factors connecting the systemic and individual conditions of academia today is the operative hegemony of metric culture (Ajana 2017; Lupton 2016; Moore and Robinson 2015) - what David Beer (2016) calls 'metric power'. Beer's analysis compellingly demonstrates that "metrics are now an embedded, multi-scalar, and active component of our everyday lives - they are central to how those lives are ordered, governed, crafted, and defined" (Beer 2016, 4). To be clear, this is not to say that the existence and use of metrics is a new phenomenon or unique to the digital age; measurement has long been a staple in, for instance, population control, commercial production and labour management efforts (e.g. Braverman 1998; Noble 1997; Foucault 2007). But what is novel, as Beer suggests, is the extent to which "systems of measurement have escalated and intensified over recent years, especially with the rise of new data assemblages and their integration into the very fabric of our lives" (Beer 2016, 4). In this article, we aim to examine how metric power - as a derivative structure of neoliberal capitalism - operates in the British university, and how it acts as the conceptual sinew that binds the macro and micro scales of academic practice.

To begin, and as context, we examine how neoliberal capitalism has impacted upon the societal reputation of knowledge and the public role of the university. From there, we offer a systemic analysis of the British university as a structure of neoliberal capitalist values and mechanisms. Indeed, as Gigi Roggero (2011) and Rosalind Gill (2014) show, "the University has emerged as a cypher or barometer of broader transformations within the economy, and thus a privileged space for 'reading' the contours of contemporary capitalism" (Gill 2014, 17-18). The university thus functions as a productive metaphor for the (mis)workings and (il)logics of a particular economic dogma. As such, we home in on how this economic ideology translates into specific metrics of performance, whether departmentally, institutionally, nationally or internationally.

Following our institutional analysis, the article shifts focus to the ways in which metric power affects the individual academic or 'service provider', in market parlance. We find that these experiences are routinely shaped by the imperative for 'compulsory individuality' (Cronin 2000, in Gill 2016), whereby “individuals are now increasingly required to tell the story of their lives as if they were the outcome of deliberative planning and choice" (Gill 2016, 42). These practices of 'intentional autobiography' consolidated and coherent narratives of the self-coincide with the processes of individualisation (Bauman 2001; Beck and Beck-Gernsheim 2002) by which the individual is held ultimately responsible for the outcome of his/her life. Success as an academic is thus converted into a purely personal accomplishment (or failure) disconnected from the wider social, political and economic contexts that circumscribe knowledge, action and possibility. In focusing on this individualisation (Skelton 2005), we identify some of the choices academics face and their emotional consequences.

After taking account of systemic and individual expressions of metric power in the British university, we focus on strategies of response and resistance. As academics and as workers, we believe firmly in the power of critique. But we also believe that an essential function of critique is its ability to inspire change. To that end, we conclude with thoughts on how we might reimagine the modern university. 


\section{Why Metrics and Why Now?}

As an ideology, neoliberal capitalism reveres competition, promotes social Darwinism and valorises profit (Wigger and Buch-Hansen 2013). It decries regulation and discourages solidarity outside short-term instrumentalism (Giroux 2011). Neoliberal capitalism has been making inroads in British higher education for decades, and as a conceptual framework it substantially informs the context within which the British university must now be thought.

Contributing to this context is a more recent development: widespread rhetorical (and mediatised) disdain for experts and expertise (Nichols 2017). With the rise of global populisms (for a discussion of the Turkish case see, for example: Bakırezer, Demirer and Yeşilyurt in this issue) we see sustained, public attacks on knowledge so extreme that being labelled an intellectual can now be considered pejorative. This sentiment was captured in a recent New Yorker illustration of a man standing in the aisle of a plane insisting, "These smug pilots have lost touch with regular passengers like us. Who thinks I should fly the plane?" (McPhail 2017). In a socio-political climate so hostile to the exercise of knowledge and reason, is it any wonder that figures like the Donald Trump and Nigel Farage are lauded? Or that 'expert' no longer suggests information authority and qualifications but instead signals disconnect from, and scorn for, the masses?

Such discursive attacks on knowledge and expertise sit neatly alongside neoliberal capitalism's reverence for profit-oriented individualism. While knowledge is decried, the tenets of economic competition are encouraged and reproduced. This situation bodes poorly for universities - especially publicly-funded universities - and the academics working in them. This is largely because cultural disregard for knowledge means that universities and academic staff are now required to defend their existence through an alternate language: one of cost-benefit accounting. In other words, knowledge for knowledge's sake is no longer sufficient justification for why we need universities.

With the university effectively forced to articulate itself through the lexicon of neoliberal capitalism, education is recast as a service and educators as service providers. Universities and academics have been reconstituted as extensions of the market (and not only in the UK, e.g. Roggero 2011; Thornton 2013). From this perspective, educating in support of curiosity and criticality is deemed anachronistic, elitist and impractical. With the university thus reconfigured as a business, this narrows both the legitimacy and availability of spaces for thought not aimed at quantifiable forms of understanding (e.g. innovation and commercialisation, grant capture, graduation rates and so on). Ultimately, as Wendy Brown $(2015,176)$ argues, when "education [is seen] as primarily valuable to human capital development, where human capital is what the individual, the business world, and the state seek to enhance in order to maximize competitiveness", the victim is democracy itself. After all, when knowledge is no longer considered a public good or a universal need, then what use is an informed citizenry?

This shift toward knowledge as a private (and thus individual) good is captured by two converging trends: the previously discussed demonisation of expertise on the one hand, and the celebration of the entrepreneur-cum-celebrity on the other (e.g. Steve Jobs, Mark Zuckerberg). This paradox demonstrates that "neoliberalism [...] is best understood not simply as economic policy, but as a governing rationality that disseminates market values and metrics to every sphere of life and construes the human itself exclusively as homo oeconomicus" (Brown 2015, 175). It is precisely in the circulation of this 'governing rationality' that metrics prove so powerful for under- 
standing how higher education is currently organised. Below, we locate and unpack expressions of this power.

\section{Making the University: Institutional Neoliberalism and Metric Power}

Metric power facilitates "focus on the relations between measurement, circulation, and possibility" (Beer 2016, 8). It is a framework that allows insight into the mechanisms and uses of quantification, and one that "contribute[s] towards expanding our understanding of the role of metrics in the performance of contemporary society" (Ibid.). Within the university, the role of metrics is extensive and wide-ranging. Indeed, a 2015 report by the Higher Education Funding Council for England (HEFCE) reflected on the 'metric tide' that has washed over higher education in Britain (Wilsdon et al. 2015). The report hints that this dominance of metrics is, in large part, a consequence of how the university is currently conceived by government: namely, as an economic entity which must demonstrate 'value for money' and represent itself through the discourses of competitiveness, efficiency and accountability. From this position, knowledge is transformed into a product and commodity no longer isolated from the marketplace or its rationalisation processes. In other words, government sees higher education as an industry like any other. This is consistent with William Davies's $(2014,38$, in Beer 2016, 134) observation that "reconfiguring institutions to resemble markets is a hallmark of neoliberal government". The provision of knowledge, it would seem, no longer deserves protection from market forces.

This view is confirmed by examination of HEFCE's own governance structures. The agency that is "responsible for distributing public funds for higher education in England"1 and for quality assessment reviews ${ }^{2}$ was, until mid-2016, sponsored by the Department for Business, Innovation \& Skills (now the Department for Business, Energy and Industrial Strategy). ${ }^{3}$ Higher education, in other words, is conceived by policymakers as just one industry among a portfolio of others. Given this overt commercial framing, the prominence of metrics in the university should come as no surprise. To that end, the previously mentioned HEFCE report links the metric tide in academia to:

growing pressures for [...] evaluation of public spending on higher education and research; demands by policymakers for more strategic intelligence on research quality and impact; [...] competition within and between institutions for prestige, students, staff and resources; and increases in the availability of real-time 'big data' on research uptake, and the capacity of tools for analysing them (Wilsdon et al. 2015, viii).

\footnotetext{
${ }^{1}$ HEFCE (2017), TEF National contextual statement for England. Available at: http://www.hefce.ac.uk/media/HEFCE,2014/Content/Learning,and,teaching/TEF/Guidance/ England-TEF-statement.pdf, accessed May 22, 2017.

2 http://www.hefce.ac.uk/reg/assuring/HEFCEs, statutory, duty, accessed 22 May 2017.

${ }_{3}^{3}$ HEFCE, http://www.hefce.ac.uk/about/unicoll/government, and Department of Business, Innovation \& Skills homepage, https://www.gov.uk/government/organisations/departmentfor-business-innovation-skills, accessed May 22, 2017. In July 2016, HEFCE's sponsor department became the Department for Education, but it continues to work with the Department for Business, Energy and Industrial Strategy.
} 
These pressures reflect the extent to which metrics now dominate the university, while actively contributing to the audit culture that saturates British academia (Gill 2014; Shore 2008; Power 1994). Audit culture takes myriad institutional forms, of which the Teaching Excellence Framework (TEF), the Research Excellent Framework (REF) and various League Tables are perhaps the most visible. As such, we focus on these below.

The Teaching Excellence Framework was announced in a May 2016 Government White Paper, Success as a Knowledge Economy: Teaching Excellence, Social Mobility and Student Choice. The TEF was pitched as a sector-wide accountability exercise aimed at recognising, quantifying and promoting high-quality university teaching. Here, top TEF performers would be rewarded with the power to increase student fees. In "incentivising excellent teaching and giving all students better information on where the best provision is found" (Department for Business, Innovation \& Skills 2016, 9-10), the exercise will also necessarily identify underperforming teaching units. The Minister of State for Universities and Science, Jo Johnson, announced in his foreword to the White Paper that "through the TEF [...] we will ensure there are clear incentives for higher education institutions to deliver value to students and taxpayers" (Ibid.). This policy aim succinctly encapsulates the neoliberal capitalist project, where what is valuable is that which is measurable, cost-effective, incomegenerating and conducive to consumer choice. In addition, as the authors of the Alternative White Paper for Higher Education $(2016,28)$ argue, the metrics used for the TEF - for example, student satisfaction statistics - risk undermining teaching quality instead of improving it.

The White Paper's title links knowledge to the economy, not to learning. This further demonstrates that UK policymakers appreciate knowledge cultivation primarily through the narrow lens of economic development. According to the government, "teaching excellence matters, not only for students and taxpayers, but also for those who care about social mobility, since we will not truly begin to reduce inequality unless more students fulfil their aspirations and progress on into their chosen careers" (Department for Business, Innovation \& Skills 2016, 13). This justification for the TEF hinges exclusively on metrics of economic success: value-for-taxpayer-money, 'social' mobility and employment rates. The task of educating, in other words, is a means to a (purely fiscal) end where knowledge acquisition is a modality for economic reproduction and advancement.

As much as we would like to take seriously the TEF's stated aim of reducing inequality, the attendant logic is flimsy, at best. The TEF is a competitive exercise and the data it generates will be used to construct a league table. The process of ranking universities - in this case, by alleged teaching quality - results in performance indicators that range from high to low. The very task of ranking institutions necessarily foregrounds inequalities: some universities will do well, others will do less well. It is difficult to understand, then, how a competitive exercise that quantifies relative excellence (and failure) will be able to reduce inequality when the very point of the exercise is to highlight performance differences between institutions. In other words, how can measuring inequality and promoting competition lead to greater equality? It is useful to consider this question vis-à-vis William Davies's argument that "a society that celebrates and encourages 'competitiveness' as an ethos, be it in sport, business, politics or education, cannot then be surprised if outcomes are then highly unequal" (Davies 2014, 41; see also Beer 2016, 133-134). Inequality here is a key product of neoliberal systems of production, and it is a product with utility. Davies notes that "critical denunciations of inequality as 'illegitimate' may miss the ways in 
which inequality is 'legitimate' because it is publicly and enthusiastically legitimated" (2014, 41, emphasis original). As such, we suggest that the TEF ought to be regarded as a public, state-sanctioned legitimation, if not acceleration, of inequality.

Moreover, we can consider the Research Excellence Framework (REF) - the much-maligned, sector-wide audit of university research - in the same light. Rising from the ashes of the Research Assessment Exercise (RAE), the REF aims to measure and rank universities by the quality of their research activities (see Jump 2013). The RAE was initially conceived in the 1980s as an exercise by which to determine distribution of central government research funding in a climate of decreased state investment in higher education (Evans 2004). The universities that performed best would effectively get the most research funding.

Today's REF performs a similar function. Through a variety of metrics and data sources (see Stelmach and Von Wolff 2011, 71), the REF foregrounds and reifies inequalities within UK higher education. The REF relies on expert sub-panels to quantify research quality by subject area (Ibid.). These panels are a means of harmonising disciplines across universities; they facilitate systemic standardisation of, say, sociology or philosophy, that allows for easy comparison between different academic departments offering the same degree. The REF also evaluates research quality at the institutional level, measuring factors like impact and research environment. ${ }^{4}$ Coordinated every five years (or so) by HEFCE, the REF produces a powerful league table by which British universities' fiscal and reputational health is (re)produced.

The resulting hierarchy informs other indices of academic competitiveness because it contributes to other university league tables - for instance, the Complete University Guide, The Times and Sunday Times University Guide and the QS World University Rankings. League tables, Thornton $(2013,131)$ observes, are a "manifestation of the way competition policy is retained at the forefront of the institutional academic agenda. They entail universities competing with one another for rankings at the national and international level, based on a range of reputational factors". Through league tables we see the vagaries of reputation named and quantified, and wrought through the hegemony of metric power.

In the higher education industry, universities are concerned with market share visà-vis their competitors. After all, HE is big business and for the UK, a big export product. The lobbying organisation Universities UK, for example, reported that in 2014-2015, "on- and off-campus spending by international students and their visitors generated $£ 25.8$ billion in gross output". ${ }^{5}$ Such large financial stakes make academic measurement all the more appealing. The REF, TEF and university league tables can thus be understood as industry-specific performance indicators. They are the frameworks by which university quality - understood in the neoliberal context through descriptors like 'entrepreneurial' and 'competitive' - is quantified. Moreover, they establish concrete metrics that double as benchmarks against which future performance can be measured, and rewarded (or punished) accordingly. Indeed, as HEFCE's metric tide report indicates, "across the higher education sector, quantitative data is now used far more widely as a management aid, reflecting developments in the private sector over recent decades" (Wilsdon et al. 2015, 179). Metrics, then, are

\footnotetext{
${ }^{4}$ http://www.ref.ac.uk/panels/assessmentcriteriaandleveldefinitions, accessed May 23, 2017.

5 Universities UK, 2017, http://www.universitiesuk.ac.uk/policy-andanalysis/reports/Pages/briefing-economic-impact-of-international-students.aspx, accessed
} May 23, 2017. 
not about measurement for measurement's sake. Rather, they are a means of disciplining universities and academics by laying bare what is valued (and not) in the HE marketplace. In the following section, we focus in greater depth on the experiences of individual academics to consider how metric power works at the micro level.

\section{Making the Academic: Measurements of Self}

Having explored institutional expressions of metric power in the university, we now wish to consider how these systems impact individual academics. How does today's metric culture and the neoliberal conception of knowledge production affect the academic practitioner?

To answer this question, it is essential to return to the currently dominant societal understanding of knowledge as industry. As Margaret Thornton $(2013,131)$ notes, "instead of being regarded as a public good, higher education has become a commodity. Within the new 'industry', students have become customers who purchase a product from service providers". This move away from knowledge as a public good has consequences for the subjectivities available to academic staff. One finds that these 'new' subjectivities have little in common with the ideals of passionate vocation so often invoked in the popular imaginary (Gill 2016). Indeed, Thornton suggests that today's ideal academic is the "technopreneur" (Thornton 2013, 130) who is "expected to be economically productive [...] [This] new culture exerts pressure on academics to create knowledge - not for its own sake [...] but for its use value in the market" (Ibid., 131). This ideal is encouraged through imperatives for knowledge transfer or third mission activity (e.g. Gaze and Stevens 2011).

With the educator-researcher recast as a service provider and an economically productive unit, a new lexicon narrates the academic self. That lexicon is shaped by the values of neoliberal capitalism. Herein, "'good investment' is the way departments speak of new hires, and 'entrepreneurial' has become a favored term for describing exceptionally promising young researchers" (Brown 2015, 195). Brown goes on to argue that this mechanistic commercialisation of knowledge production creates two tiers of scholarship. The first is research that is institutionally recognised and therefore good for one's career. The second is research that delinks knowledge from corporate-ladder calculation and is aligned instead with thinking as an ethical doing. In other words, the professionalisation of higher education - with incentives around grant capture and knowledge transfer, among others - "widen[s] the breach between research valued and rewarded by the disciplines and research that is profound, useful, exciting, or relevant to making better worlds or better citizens" (Ibid., 196; see also: Gaze and Stevens 2011). It would thus seem that inside the neoliberal university, economics trumps civic responsibility.

Unpacking this prioritisation reveals an interesting perversion of how the academic - and her societal function - is understood. Consider the reputational and structural position of teaching activity in the university. In the UK (though not only), university budgets rely heavily on tuition fees. Data collated by the Higher Education Statistics Agency (HESA 2017, Table 16) shows that in 2015-2016, UK universities received 48 per cent of their income from tuition fees and education contracts. By contrast, those same universities received only 17 per cent of their total income from research grants and contracts (Ibid., Table 16). ${ }^{6}$ Structurally, these figures suggest that teach-

${ }^{6}$ These figures represent averages across the UK higher education sector; the numbers can vary widely between individual universities. These figures also do not take account of other 
ing represents a far more vital (i.e. lucrative) activity than research. In neoliberal accounting parlance, it 'outperforms' research as an income stream by nearly three to one. As such, one would be forgiven for taking this thinking to its logical (capitalist) conclusion: if teaching earns so much more money than research, the ideal academic is one who does more teaching and less research. And yet...

This is where illogic comes into play. For students and staff alike, the desirability of a university is driven in large part by its reputation - its cultural capital. And that derives heavily from the research profile of an institution, measured by the REF, and variously by grant capture, knowledge transfer, research outputs and perhaps soon, citation counts (Gruber 2014, 166). So while teaching earns universities money, it does not garner prestige. Yet prestige is what enables universities to attract 'the best' people. Thus, academics are incentivised to focus on our research, because that is what benefits individual careers and institutional reputations. It is through our research activities that we distinguish ourselves in a highly competitive marketplace. Unfortunately, such rational prioritisation drives academics away from the task of educating students (never mind pastoral care). As Brown $(2015,196)$ laments:

neoliberalization has dramatically depressed the status of undergraduate teaching within the academic profession as a whole and at public research universities, in particular. Since research is all that enhances scholarly value, all savvy young faculty learn to allocate most of their human capital portfolio to it. Teaching steals precious time from research, and too much care for undergraduate teaching also stigmatizes academics.

The TEF was introduced, in part, to address the disincentive to teach. Yet because the TEF is simply another set of metrics and rankings - in other words, because it employs the same instrumentalist logic that is under critique here - we expect the exercise will do precious little to improve teaching's reputation or salvage it from the neoliberal values of individualism, efficiency and profit. Instead, it will likely contribute to the academic's (already heavy) load of performance pressures.

Metric power, as an outgrowth of neoliberal ideology, holds sway over academic livelihoods in other ways. Perhaps most pernicious are the pressures and attendant metrics of publication. In the UK, the familiar 'publish or perish' motto has been rewritten. It is no longer enough just to publish; one must publish in the 'right' formats, with the 'right' presses, in the 'right' journals and in the 'right' timeframes. While it is not official guidance, book chapters are undesirable REF submissions. Likewise, for monographs, university presses are preferable to commercial publishers. For articles, one should target journals with high impact ratings. And above all, one must produce

important income sources. Specifically, they do not include funding body grants, which represent a further 17 per cent of university income (HESA 2017, Table 16). These grants consist of research and teaching grants, but we do not include these details because the precise split between research and teaching grants varies by institution. Another 17 per cent of university income in 2015-2016 came from what the financial report terms 'other income'. This consists, in part, of 'other services rendered' to 'BEIS Research Councils, UK central government/local authorities, health and hospital authorities, [and] EU government bodies'; income from 'residences and catering operations'; grants from local authorities; and 'income from intellectual property rights' (HESA 2017, Table 16). 
a requisite number of publications per REF cycle ${ }^{7}$ that will be dubbed 3-star ('internationally excellent') or 4-star ('world-leading') by subject area sub-panels.

Quality in research matters. But so does quantity. As shown above, the REF consolidates both imperatives by expecting each academic to submit an average of 2.5 publications of 3-, or ideally, 4-star quality in the upcoming assessment cycle. This pushes for an acceleration of output, where one is compelled to publish as much as possible in order to meet that REF target. The most efficient way to achieve this is by getting as many publications out of a single research project as one can, regardless of whether one has anything new to say. At a recent conference, a speaker wryly described this strategy as 'slicing the salami really thin'. The successful academic, in other words, is one who is concerned with maximum value extraction and resource efficiency. This model might be applicable for management of limited natural resources like petroleum or silicon, but for us, its application to knowledge production is deeply troubling. Such quantitative reductionism is also seen in the growing emphasis on citation counts (Hicks et al. 2015). As Thomas Gruber $(2014,166)$ notes, "accumulating as many citations as possible [is an] important 'means' for academics to improve their own and their institution's reputation and to advance their career ('ends')".

Metric power affects academic priorities in other ways. Among these is the imperative for grant capture. In a neoliberal economy with ever-decreasing state support for higher education, it is increasingly important that individual academics acquire external grants to support their research. Such grants contribute to universities' balance sheets but their import far transcends profit-loss accounting. First and foremost, bigenough grants enable academics to be 'bought out' of their teaching obligations. Because, and as previously discussed, teaching is a reputationally undesirable activity, it is in academics' interest to avoid it. Grants provide a key mechanism by which to do so.

Where buyout occurs, universities generally use a portion of the grant to hire temporary staff to cover the permanent employee's teaching load. This mechanisation of grant income fuels an ongoing labour crisis in British (but not only) universities. At its simplest, the crisis can be understood as an academic class system. The bottom of the hierarchy is populated by those on short-term, usually part-time contracts. These colleagues are paid hourly for teaching and marking, and receive no institutional research support. Meanwhile, at the top of the hierarchy are academics on permanent full-time contracts that can go after research grants, with access to university resources, and then use grant income to get teaching buyout and secure more time to produce more research outputs (i.e. what advances careers).

This structural arrangement can result in a toxic emotional cocktail at both ends of the academic class system. Precarious and permanent staff alike feel severe pressure to perform in industry-approved, quantifiable ways and this routinely leads to working far more hours than contractually obligated (e.g. Gill 2016, 45-46). Evenings and weekends become extensions of the workday, providing much-needed opportunities to catch up or, at least, keep oneself from drowning. In Rosalind Gill's taboobusting Breaking the Silence, she collates stories from the working lives of academ-

\footnotetext{
7 The 'REF 2021: Decisions on staff and outputs' document specifies that 'the average number of outputs required per FTE will be $2.5^{\prime}(2017,6)$. This translates into a minimum of one output per individual to a maximum of five outputs,

http://www.ref.ac.uk/media/ref,2021/downloads/REF\%202017 04\%20Decisions.pdf, accessed November 21, 2017.
} 
ics and notes "the palpable anxiety that pulsates through these accounts: anxiety about falling behind, missing something important, going under" (Ibid., 47). There are only so many hours in a day. Will you spend them working on a journal article or answering student emails? Either response suggests the production of guilt. If you choose to work on the article, you are aware you are ignoring students. If you choose the emails, you feel guilty that you're shirking your responsibilities as a researcher. This guilt and anxiety is an intimately familiar, perhaps even normalised, feature of contemporary academic life. But its persistence ought to be denaturalised and understood within the context of increasing workloads and pressures on academics to excel in multiple roles, from 'world-leading' researchers to 'excellent' teachers and 'service providers' to professional administrators performing recruitment and (self)marketing tasks. In other words, today's academics are expected to do much more than they were in previous generations (see Gill 2016, 46). Is it any wonder, then, that anxiety, stress and depression feature so prominently in contemporary accounts of what it is to be an academic?

As professionalised subjects disciplined by neoliberalism, many of us have internalised the competitive ethos and metrics of success articulated by the modern university. This internalisation impacts the choices we make; it guides the priorities we (don't) follow through on. It also impacts our individual and collective strategies for response and resistance to our working conditions. We examine these strategies below.

\section{Making the Resistance: Beyond the Neoliberal University}

While increased precarity and the rise of neoliberal audit culture have had significant impacts on academic lives, we have seen surprisingly little collective action from academic workers to resist and challenge these developments (Willmott 1995; Davis and Bansel 2005; Gill 2016). Reasons cited for the lack of resistance range from the passion for academic work as vocation (Ross 2000,22 ), "the seductions of relatively autonomous working lives" (Gill 2016, 53) and the relative privilege of being in a permanent academic position, to not knowing what to resist and how, to simply being exhausted (Gill 2016). At a structural level, neoliberal reforms have diminished spaces for democratic decision-making within the university and thus reduced the ability of academics to shape the university in meaningful ways (Parker and Jary 1995). Divisions between permanent academic staff and contingent workers have further complicated the prospects of taking collective action. Over two decades ago, Hugh Willmott $(1995,1003)$ warned that the expansion of short-term and hourly teaching contracts cushions the deterioration of working conditions for permanent academic staff and thus stalls resistance. Today, his warning reads prophetic.

The neoliberal university has impacted academic selves in ways that serve to ensure compliance. Parker and Jary, for example, suggest that "many academics may begin to construct a fetishism of rankings as a measure of the worth of self and other" $(1995,331)$. David and Bansel $(2005,55)$ argue that academics have internalised metrics of publications, teaching loads and research funds as measures of success. Their "research suggests that external pressures are immediately translated by academic workers into internal pressures for which one must accept responsibility" (David and Bansel 2005, 51). Similarly, Gill $(2016,52)$ argues that academics are particularly susceptible to act as responsibilised subjects: "Neoliberalism found fertile ground in academics whose predispositions to 'work hard' and 'do well' meshed perfectly with its demands for autonomous, self motivating, responsibilised subjects".

Within the neoliberal narrative of individual achievement and responsibility, struc- 
tural problems are often perceived as personal failures. In such a deeply individualised climate, the struggles to meet externally defined standards and to effectively manage growing workloads tend to lead to self-blame rather than collective action. When something goes wrong - when, say, one receives a hostile peer-review or has a grant application rejected - there is no one to blame but oneself. Accordingly, success and failure "are understood to reflect on the value and worth of the individual, rather than the values of the institutions that make intolerable demands" (Gill 2016, 48). As a consequence, as Willmott stresses, performance monitoring and the erosion of pay and conditions have led to "simmering resentment and individual withdrawal [...] rather than organized resistance" $(1995,1002)$. Drawing analogies to the extensive body of research on cultural workers, Gill $(2016,51)$ highlights that the tendency to frame the pressures and stresses of academic life as individual failures often produce feelings of guilt and shame and thus "is profoundly silencing and isolating".

Upholding potentials for structural critique and collective resistance as alternatives to individual self-blame seems crucial not only for the sake of improving the conditions of academic labour, but also for the prospects of a critical academia. As Mary Heath and Peter Burdan argue, academics "have a unique social responsibility to critically examine social institutions, including the university" $(2013,381)$. Any exploration of resistance within and against the neoliberal university needs to take the above limitations seriously but without overlooking a growing array of ideas, proposals and practices to contest neoliberal academic life and imagine alternatives. Contrary to the above accounts, Gina Anderson $(2008,252)$ argues that "resistance is a likely response to managerialism" within the university since academics are inured to critique rather than acceptance. Resistance can take many shapes and forms. While David and Bansel $(2005,57)$ argue that it requires acts of collegiality, collaboration and collectivity, many of the micro-resistances Anderson (2008) identifies in her research on Australian academics seem to rely on individual resistance rather than collective action. These individual tactics include minimal compliance with managerial demands or refusing to participate in student evaluations, staff surveys, workload interviews and other managerial exercises (Ibid.).

To further explore the various starting points for resistance, we identify four different responses that can be used to express discontent with neoliberal academia: abstention, attack, adaptation and alternatives. This framework is based on a typology Dieter Rucht $(2004,31 \mathrm{f})$ introduced to describe different ways that social movements engage with mass media. Abstention refers to a strategy of withdrawal and retreat: a refusal to engage with mass media. Attack describes "an explicit critique of, and sometimes even violent action against, the mass media" (Rucht 2004, 31). The strategy of adaptation accepts the mass media's rules and tries to exploit them to further the movement's goals. The final strategy describes the attempt to build independent movement media as alternatives to established mass media. In the following, we will apply these four strategies to how academics are dealing with the injuries and challenges of neoliberal academia.

\subsection{Abstention}

For many, abstaining from an academic career is not a choice. The increased prevalence of contingent employment and precarious work in academia often forces early career scholars to look for career paths outside the university. However, even for those with more permanent positions, sometimes the only way to escape the problems of academic labour is withdraw from it. 
There are many reasons to take the conscious decision to abandon the pursuit of an academic career, and the decision to quit academia is not always just a personal one. Often it is an active gesture of resistance against university power structures and working conditions. For example, in 2016, Sara Ahmed resigned from her position as director of the Centre for Feminist Research at Goldsmiths, University of London in protest against the university's response to alleged sexual harassment of students (Ahmed 2016). Liz Morrish left her university job after facing disciplinary procedures for speaking out about the stresses and pressures of academic labour in front of students and in public. Her decision to leave was an attempt, in Morrish's (2017) words, to "reclaim my academic freedom - outside the academy". For Tamura A. Lomax, the decision to quit academia was a form of resistance that allowed her to publicly condemn the racism and sexism black women often face within university environments. She left because "the growing precariat within academe impacts those who are racialized and gendered in the most harmful ways and divides the academic master/servant class even further" (Lomax 2015).

Rather than framing abstention from academic life solely as a matter of personal choice, it is important to acknowledge that who gets in and who doesn't, who quits and who stays, tends to reflect existing inequalities of race, class and gender. Women, for instance, are more likely to leave academia. According to a 2006 study of chemistry PhD students in the UK, only $12 \%$ of women in the third year of their PhD studies wanted to remain in academia, compared to $21 \%$ of their male counterparts (Royal Society of Chemistry 2008). Qualitative follow-up research showed that it was particular "experiences of the structures, cultures, environment and norms of practice" during their PhD studies that deterred women from wanting to pursue an academic career. Among other factors, women pointed out that they "would prefer if academic chemistry was more cooperative in nature" (Ibid.).

As a resistance strategy abstention is inward-oriented, i.e. directed towards changing individual behaviour (Rucht 2004, 32). However, taking the difficult personal decision to leave academia behind can itself highlight the need for change and inspire others to act.

\subsection{Attack}

While abstention is directed inward, the strategy of attack is outward-focused (Rucht $2004,32)$. Attack can be both individual and collective. Individual attacks against the neoliberal university may include deciding to confront managers or Vice-Chancellors at staff meetings, speaking out to students about managerialism in the university or opting for minimal compliance with managerial demands (Anderson 2008). Collective forms of attack have traditionally been organised through labour unions. In the UK, the University and College Union (UCU) is making important efforts to make visible and improve working conditions in academia, making the fight, for example, against casualisation and the gender pay gap campaigning priorities. However, thus far unions have not been very successful in fending off wage declines, increasing workloads or institutional reliance on temporary (and often part-time) contracts. Gill (2016, 45) suggests that the "idea of scholarship as a 'noble' calling or vocation" might have contributed to the "failure over many decades to secure pay deals that even keep pace with inflation". She also stresses that the educational and cultural capital that comes with the academic profession risks masking financial hardship (Gill 2016, 45). But, as one of our academic friends put it, 'I can't eat cultural capital'.

A recent UK example of the limited success of union activism is the pay deal UCU agreed in May 2014. After six days of strike action and months of campaigning, the 
deal merely reaffirmed a $1 \%$ pay rise that had already been on offer for the academic year 2013-2014 and included a promise for a $2 \%$ rise the following year. ${ }^{8}$ This deal came after real wages had fallen by $13 \%$ since 2008 , and as such, it was criticised as being not a "pay deal" but in fact a "pay cut" (Freedman 2014). However, organised resistance in universities is not only coming from academic staff. A more successful campaign was, for example, started in 2012 by outsourced cleaning staff at the University of London. The 3 Cosas Campaign demanded improvements for contract workers employed by the University, focusing primarily on paid sick leave, paid holidays and pensions. After over a year of strikes and protests the campaign achieved significant improvement in terms of pay, including holiday and sick pay entitlements. ${ }^{9}$

Collective resistance in the form of union activism faces significant challenges within the contemporary context. In universities, the rise in student fees and the redefinition of students as customers has intensified divisions between academics and students and thus threatens the potentials for solidarities between them. Furthermore, considering growing workload demands, strike action is less effective if it means that work is not in fact stopped but merely postponed to the next day, the evening or the weekend. And yet, the union as an institutionalised means for collective mobilisation and solidarity remains a unique tool for resistance and giving up on it would mean a historic defeat.

\subsection{Adaptation}

A third possible response to the stresses of academic life is to develop practical strategies for buffering periods of intense pressures and excessive work demands. This can be an important survival tactic for maintaining sanity and avoiding burnout. However, in the long-run such a strategy contributes little to efforts aimed at contesting and changing the conditions of academic labour. For example, in an article entitled 'How to live less anxiously in academe', Cederström and Marinetti (2016) argue that hopes for sudden resolution to the problems of academic life are futile. Instead, they suggest four strategies for academics "who have grown tired of this futile moaning and wish to do something about it". These strategies include giving up institutional aspirations, embracing the fact that academics are amateur writers and amateur teachers, stopping to write badly and starting to teach well.

On the one hand, this advice to finally start writing and teaching well seems to add to, rather than reduce, the pressure and anxiety of academic life. On the other hand, the suggested strategies offer a deeply individualised outlook. Cederström and Marinetti (2016), for instance, advise "to keep a low profile, and just live up to the basic expectations. Smile and nod, but don't overdo it". Such a strategy only deals with the effects of managerialism and excessive workloads rather than the causes. It does not demand or create systemic change. As Davies and Bansel $(2005,55)$ argue, "drawing boundaries around work might help academics manage their workloads but it has little impact on the systemic causes of their distress". As a consequence of such efforts of "work deflection", workloads are likely to simply be shifted to other members of staff. If some individuals, for example, refuse to take on additional admin or committee work, others will be burdened with these tasks. One's colleagues, in other words, will have to pick up the slack. This further exacerbates workload inequalities between academics, in this case between those who are comfortable saying no to

${ }^{8} \mathrm{https://www.ucu.org.uk/hepay13,} \mathrm{accessed} \mathrm{May} \mathrm{12,} 2017$.

9 https://3cosascampaign.wordpress.com/about, accessed May 12, 2017. 
taking on additional work tasks and those who are not (or those who cannot - e.g. those on temporary contracts or junior academics on probation). Moreover, this inequality is likely to evolve along gendered lines. Finally, a strategy that only tackles symptoms will ultimately exacerbate frustrations and fuel feelings of inadequacy. As Ryan explains, focusing solely on avoiding symptoms "allows us to survive as zombies rather than escape the plague" $(2012,10)$.

\subsection{Alternatives}

A way to address the tension between passion for academic work and the realities of academic labour is to reclaim higher education and create alternatives to the neoliberal university. The drive to build alternatives is based on a conscious conceptualisation of "the university as a set of practices that are historically contingent and capable of transformation" (Heath and Burdan 2013, 398). Unlike the previous three strategies, alternatives are necessarily collective. Alternatives cannot be built by isolated individuals but require a group of people to work together to create systemic change. Alternatives can be envisioned both within and outside established universities.

Ideas for creating alternatives within established academic institutions focus on actively resisting individualisation and competition, and instead creating work cultures based on care, co-operation and solidarity. As the SIGJ2 Writing Collective (2012, 1055) puts it, this is an attempt to "find ways to be the change we want to see in academia". To that end, the Collective suggests focusing on collective instead of individual publishing, making research outputs freely available online, being generous when assessing each other's work and placing value on activities such as community engagement or activism when evaluating academic CVs. The Collective also proposes strengthening links between scholarship and activism in order to more directly challenge the structures of neoliberal capitalism (The SIGJ2 Writing Collective 2012, 257f). A similar proposal comes from a group of feminist writers who suggest slow scholarship as an "alternatives to the fast-paced metric-oriented neoliberal university" (Mountz et al. 2015, 1236). Starting from a feminist ethics of care they frame slow scholarship as an explicitly collective strategy of resistance where the goal is to cultivate "caring academic cultures and processes" (Mountz et al. 2015, 1238) and reclaim time for collaborative and care-full scholarship.

Unlike strategies of adaptation discussed earlier, the call for slow scholarship does not just explore ways to improve individual resilience and well-being, but seeks to develop alternative cultures within the university through collective action. The group highlights that "slow scholarship cannot just be about making individual lives better, but must also be about re-making the university" (Ibid.). They propose a set of strategies and actions that can be taken collectively to shift individualised, competitive, fast-paced and metrics-oriented academic cultures. These include supporting colleagues and students to develop slow strategies, counting as legitimate and valuable a wider range of work such as collaboration and advocacy when discussing promotion, tenure or hiring, organising spaces for collaboration and sharing of ideas such as reading and writing groups, coffee breaks or joint conference panels, taking care of and supporting colleagues, writing fewer emails, turning off email at evenings and weekends, prioritising time to think, making time for careful writing, sharing strategies of saying no when overburdened with work as well as saying yes to opportunities to support slow scholarship, reaching for the minimum and being satisfied with good enough. Similarly, the Res-Sisters, a feminist collective of early career academics, stress that collectivity is needed in order to resist neoliberal individualisation, "providing support networks and helping us to organise against institutional and societal in- 
justices" (2016)..$^{10}$

These suggestions focus on reclaiming agency for academic workers and challenging feelings of powerlessness. They highlight that, despite incentives to do so, academics do not need to act in competitive ways but can instead join together and behave differently to actively re-imagine academic work cultures in a way that prioritises care, critical thinking and activism over metrics like citation counts and publication numbers.

While the above proposals focus on transforming universities from within, others highlight the need for building a completely new model of the university. Some attempts to create organisational alternatives focus on proposals to build a cooperative university (Ridley-Duff 2011; Cook 2013; Neary and Winn 2016; Winn 2015). This model offers a vision of a university that is owned and controlled by its workers, including not only academics but also support staff and students. Ideas for creating a co-operative university range from converting existing universities into cooperatives to creating co-operatives at the level of department, research group and curriculum to setting up new co-operative universities (Winn 2015, 41).

A well-established example of a co-operative university is Mondragon University in Spain, which is part of the Mondragon Federation of Co-operatives. It, however, has been criticised for its overly functional approach and goal of directly benefitting the business activities of the Mondragon Corporation (Kasmir 1996; Winn 2015, 44). In the UK, the Social Science Centre in Lincoln, which is organised as a not-for-profit co-operative, is actively trying to develop alternative structures of higher education. ${ }^{11}$

The co-operative university suggests a complete reconceptualisation of academic labour and re-imagines the role of higher education in society (Winn 2015, 51; Neary and Hagyard 2010). This model challenges established divisions of labour, power inequalities and hierarchies within the university. Joss Winn $(2015,47)$ explains:

In a worker co-operative university as conceived here, there is a singular role of 'scholar', but a greater diversity of work and significantly less division of labour. According to the individual's capacity, the teacher is also a student, an administrator, a cleaner, etc., and a co-operative university need not do everything that a conventional university aims to do.

In addition to placing control and decision-making power in the hands of university workers the co-operative university furthermore proposes to radically alter the relationship between students and teachers. It conceptualises the student not as a consumer but a producer of knowledge (Neary and Winn 2016) and an "active contributor" (Winn 2015, 50). This reconfigured relation between students and teachers also calls into question the purpose of higher education (Neary and Hagyard 2010), which, as Winn suggests, "is not the production of students for wage labour, but rather the production of knowledge appropriate to the needs of humanity" (Winn 2015, 49; see also Brown 2015). Proposing co-operative alternatives to established univer-

10 The Res-Sister Manifesta, 2016, https://ressisters.wordpress.com/manifesta, accessed November 15, 2017.

${ }^{11}$ The Social Science Centre, Lincoln, http://socialsciencecentre.org.uk, accessed November 15, 2017. 
sities is thus an opportunity not just to rethink the conditions of academic labour but also the societal role of higher education. As Perez Ruiz (2015) argues, "a cooperative education would be an emancipatory education, focused in developing agency among workers (students or otherwise)".

The attempts discussed here to create alternatives to the neoliberal university whether from inside or outside established institutions - are not mutually exclusive but complement each other. Together they offer a set of starting points for envisioning higher education differently and for building a university in accordance with a different set of structures, values and practices than those imposed by today's neoliberal context.

\section{Conclusion}

This article has been concerned with the state of higher education in the UK. We have argued that the experience of the individual academic needs to be understood in the wider context of neoliberal capitalism, its institutions and its imperatives. This context is shaped by, and supports, the hegemony of metric power in today's universities - a hegemony that actively transforms knowledge from a public good to a private resource (Brown 2015).

In examining responses that resist, challenge or in some cases, compound, the problems identified, we see that responses by dissatisfied academics range in style and approach to the mantras of neoliberalism. Some decide against an academic career; others adopt a strategy of individual withdrawal within the system by trying to create and protect spaces of independence. These responses are not without problems: some offer immediate but limited relief from the pressures of academic life, while others suggest radical alternatives that require systemic change. Despite their relative (dis)advantages, all of these responses offer much-needed alternatives to self-blame, individualisation and competition.

Contra the prevailing tide of individualisation, we suggest that opportunities for positive systemic change can be found in collective efforts to disrupt the status quo and to create alternatives for how academic labour is organised. Therein, solidarity can act as an instrument of opposition to the privatisation of both knowledge and the neoliberal academic self. Considering such a strategy involves discussing the viability of union activism within the British university as well as exploring the prospect of a politics of the everyday that resists interpellation by the myth of meritocracy (Littler 2018).

Neoliberal academia frames achievement as purely personal 'accomplishments' (or failures). But as we have suggested, the individualisation of results needs to be approached as part of a much wider system of (re)production. That system has rendered the university little more than a series of numeric measures, benchmarks and accounting exercises. It is therefore urgent that we work together, through networks of solidarity, to rehabilitate the university as an institution of and for public knowledge. This cannot happen in isolation - as we have argued in this paper, the university as we know it is embedded within and shaped by the structures of capitalism in general and neoliberalism in particular. Any effort to create a different university must be part of broader alliances and movements for social change.

\section{References}

Ahmed, Sara. 2016. Resignation is a Feminist Issue. feministkilljoys. Accessed May 5, 2017. https://feministkilljoys.com/2016/08/27/resignation-is-a-feminist-issue 
Ajana, Btihaj. 2017. Metric Culture: The Quantified Self and Beyond Conference. Accessed January 12, 2017. http://metriclife.net/whats-on/international-conference -metric-culturethe-quantified-self-and-beyond

Anderson, Gina. 2008. Mapping Academic Resistance in the Managerial University. Organization 15 (2): 251-270.

Bauman, Zygmunt. 2001. The Individualized Society. Cambridge: Polity Press.

Beck, Ulrich and Elisabeth Beck-Gernsheim. 2002. Individualization: Institutionalized Individualism and Its Social and Political Consequences. London: Sage.

Beer, David. 2016. Metric Power. London: Palgrave Macmillan.

Braverman, Harry. 1998. Labour and Monopoly Capitalism: The Degradation of Work in the Twentieth Century. New York: Monthly Review Press.

Brown, Wendy. 2015. Undoing the Demos: Neoliberalism's Stealth Revolution. New York: Zone Books.

Bulut, Ergin. 2011. Creative Economy: Seeds of Social Collaboration or Capital's Hunt for General Intellect and Imagination? In Cognitive Capitalism, Education and Digital Labour, edited by Michael A. Peters and Ergin Bulut, 151-168. New York: Peter Lang.

Cederström, Carl and Michael Marinetti. 2016. How to Live Less Anxiously in Academe. The Chronicle of Higher Education. Accessed May 13, 2017. http://www.chronicle.com/article/How-to-Live-Less-Anxiously-in/237920

Convention for Higher Education. 2016. In Defence of Public Higher Education: Knowledge for a Successful Society: The Alternative White Paper for Higher Education. Convention for Higher Education. Accessed November 14, 2017. https://heconvention2.files.wordpress.com/2016/06/awp1.pdf

Cook, Dan. 2013. Realising the Co-operative University. A Consultancy Report for the Cooperative College. Accessed April 25, 2017. http://josswinn.org/wpcontent/uploads/2013/12/realising-the-co-operative-university-for-disemmination.pdf

Davies, William. 2014. The Limits of Neoliberalism. London: Sage.

Davies, Bronwyn and Peter Bansel. 2005. The Time of Their Lives? Academic Workers in Neoliberal Time(s). Health Sociology Review 14 (1): 47-58.

De Angelis, Massimo and David Harvie. 2009. 'Cognitive Capitalism' and the Rat-Race: How Capital Measures Immaterial Labour in British Universities. Historical Materialism 17 (3): 3-30.

Department for Business, Innovation \& Skills. 2016. Success as a Knowledge Economy: Teaching Excellence, Social Mobility and Student Choice: Government White Paper. Accessed May 5, 2017.

https://www.gov.uk/government/uploads/system/uploads/attachment data/file/523396/bis16-265-success-as-a-knowledge-economy.pdf

Dyer-Witheford, Nick. 2011. In the Ruined Laboratory of Futuristic Accumulation: Immaterial Labour and the University Crisis. In Cognitive Capitalism, Education and Digital Labour, edited by Michael A. Peters and Ergin Bulut, 275-286. New York: Peter Lang.

Evans, Mary. 2005. Killing Thinking: The Death of the Universities. London: Continuum.

Foucault, Michel. 2007. Security, Territory, Population: Lectures at the Collège de France 1977-1978. Basingstoke: Palgrave Macmillan.

Freedman, Des. 2014. Universities in Dispute: Pay Deal is a Pay Cut. Counterfire. Accessed April 12, 2017. http://www.counterfire.org/articles/analysis/17180-universities-in-disputepay-deal-is-a-pay-cut

Gaze, Beth and Carolyn Stevens. 2011. Running Risks of Gender Inequity: Knowledge Transfer Policy in Australian Higher Education. Journal of Education Policy 26 (5): 621639.

Gill, Rosalind. 2016. Breaking the Silence: The Hidden Injuries of Neo-Liberal Academia. Feministische Studien 34 (1): 39-55.

Gill, Rosalind. 2014. Academics, Cultural Workers and Critical Labour Studies. Journal of Cultural Economy 7 (1): 12-30. 
Giroux, Henry A. 2011. Neoliberalism and the Death of the Social State: Remembering Walter Benjamin's Angel of History. Social Identities 17 (4): 587-601.

Gornall, Lynne and Jane Salisbury. 2012. Compulsive Working, 'Hyperprofessionality' and the Unseen Pleasures of Academic Work. Higher Education Quarterly 66 (2): 135-154.

Gruber, Thorsten. 2014. Academic Sell-Out: How an Obsession with Metrics and Rankings is Damaging Academia. Journal of Marketing for Higher Education 24 (2): 165177.

Heath, Mary and Peter D. Burdon. 2013. Academic Resistance to the Neoliberal University. Legal Education Review 23 (2): 379-401.

HESA. 2017. Income and Expenditure of Higher Education Providers in 2015/2016. Accessed May 22, 2017. https://www.hesa.ac.uk/news/02-03-2017/income-and-expenditure. A detailed accounting can be accessed at: https://www.hesa.ac.uk/files/prerelease/heuk finances 1516 all tables.xlsx (especially Table 16 and Table 17).

Hicks, Diana, Paul Wouters, Ludo Waltman, Sarah de Rijcke and Ismael Rafols. 2015. The Leiden Manifesto for Research Metrics. Nature 520: 429-431.

Jump, Paul. 2013. Evolution of the REF. Times Higher Education. Accessed May 3, 2017. https://www.timeshighereducation.com/features/evolution-of-the-ref/2008100.article

Kasmir, Sharryn. 1996. The Myth of Mondragon: Cooperatives, Politics and Working-Class Life in a Basque Town. Albany: State University of New York Press.

Littler, Jo. 2018. Against Meritocracy: Culture, Power and Myths of Mobility. Oxon: Routledge.

Lomax, Tamura A. 2015. Black Women's Lives Don't Matter in Academia Either, or Why I Quit Academic Spaces That Don't Value Black Women's Life and Labor. The Feminist Wire. Accessed May 10, 2017. http://www.thefeministwire.com/2015/05/black-womenslives-dont-matter-in-academia-either-or-why-i-quit-academic-spaces-that-dont-valueblack-womens-life

Lupton, Deborah. 2016. The Quantified Self. Cambridge: Polity.

McPhail, Will. 2017. These Smug Pilots Have Lost Touch with Regular Passengers Like Us. Who thinks I should fly the plane? New Yorker. Accessed December 15, 2017. https://www.newyorker.com/cartoon/a20630

Moore, Phoebe and Andrew Robinson. 2015. The Quantified Self: What Counts in the Neoliberal Workplace. New Media \& Society 18 (1): 2774-2792.

Morrish, Liz. 2017. Why the Audit Culture Made Me Quit. Times Higher Education. Accessed April 29, 2017. https://www.timeshighereducation.com/features/why-audit-culture-mademe-quit\#survey-answer

Mountz, Allison, Anne Bonds, Becky Mansfield, Jenna Loyd, Jennifer Hyndman, Margaret Walton-Roberts, Ranu Basu, Rita Whitson, Roberta Hawkins, Trina Hamilton and Winifred Curran. 2015. For Slow Scholarship: A Feminist Politics of Resistance Through Collective Action in the Neoliberal University. ACME: An International E-Journal for Critical Geographies 14 (4): 1235-1259.

Neary, Mike and Andy Hagyard. 2010. Pedagogy of Excess: An Alternative Political Economy of Student Life. In The Marketisation of Higher Education and the Student as Consumer, edited by Mike Molesworth, Richard Scullion and Elizabeth Nixon, 209-223. London: Routledge.

Neary, Mike and Joss Winn. 2016. Beyond Public and Private: A Framework for Co-operative Higher Education. Conference Paper Presented at the Co-operative Education Conference 2016. Accessed April 29, 2017. http://eprints.lincoln.ac.uk/23051/1/CoopHEconferencepaper2016.pdf

Neeman, Yael. 2016. We Were the Future. New York: Overlook Duckworth.

Nichols, Tom. 2017. The Death of Expertise: The Campaign Against Established Knowledge and Why It Matters. New York: Oxford University Press.

Noble, David. 1997. The Religion of Technology: The Divinity of Man and the Spirit of Invention. New York: Knopf. 
Parker, Martin and David Jary. 1995. The McUniversity: Organization, Management and Academic Subjectivity 2 (2): 319-338.

Pells, Rachael. 2017. Students 'Boycotting' NUS National Student Survey Boycott, Independent. Accessed March 30, 2017. http://www.independent.co.uk/student/news/students-boycotting-nus-national-studentsurvey-oxford-university-warwickcambridge-tef-tuition-fees-a7598216.html

Perez Ruiz, Pablo. 2015. What is University For? The Columnist. Accessed May 3, 2017. http://www.columnistmagazine.co.uk/post/130265331865/what-is-university-for

Peters, Michael A. and Ergin Bulut, eds. 2011. Cognitive Capitalism, Education and Digital Labour. New York: Peter Lang.

Power, Michael. 1994. The Audit Explosion. London: Demos.

Ridley-Duff, Rory. 2011. Co-operative University and Business School: Developing an Institutional and Educational Offer. UK Society for Co-operative Studies. Accessed December 15, 2017: http://josswinn.org/wp-content/uploads/2013/11/Co-operative-UniversityInstitutional-and-Educational-Offer-Draft-3.pdf

Roggero, Gigi. 2011. The Production of Living Knowledge: The Crisis of the University and the Transformation of Labor in Europe and North America. Philadelphia: Temple University Press.

Ross, Andrew. 2000. The Mental Labour Problem. Social Text 18 (2): 1-31.

Royal Society of Chemistry. 2008. The Chemistry PhD: The Impact on Women's Retention. London. Accessed December 15, 2017.

https://www.wisecampaign.org.uk/uploads/wise/files/archive/the chemistry phdwomensre tention tcm18-139215.pdf

Rucht, Dieter. 2004. The Quadruple 'A': Media Strategies of Protest Movements Since the 1960s. In Cyberprotest: New Media, Citizens and Social Movements, edited by Wim van de Donk, Brian D. Loader, Paul G. Nixon and Dieter Rucht, 25-48. London: Routledge.

Ryan, Suzanne. 2012. Academic Zombies. A Failure of Resistance or a Means of Survival? Australian Universities Review 54 (2): 3-11.

Shore, Cris. 2008. Audit Culture and Illiberal Governance: Universities and the Culture of Accountability. Anthropological Theory 8 (3): 278-298.

SIGJ2 Writing Collective. 2012. What Can We Do? The Challenge of Being New Academics in Neoliberal Universities. Antipode 44 (4): 1055-1058.

Skelton, Christine. 2005. The 'Self-Interested' Woman Academic: A Consideration of Beck's Model of the 'Individualised Individual'. British Journal of Sociology of Education 26 (1): 516.

Stelmach, Bonnie L. and Stuart D. Von Wolff. 2011. A Challenge to Metrics as Evidence of Scholarity. European Educational Research Journal 10 (1): 64-82.

The Res-Sisters. 2016. 'I'm an Early Career Feminist Academic: Get Me Out of Here?' Encountering and Resisting the Neoliberal Academy. In Being an Early Career Feminist Academic: Global Perspectives, Experiences, and Challenges, edited by Rachel Thwaites and Amy Pressland, 267-284. London: Palgrave.

Thornton, Margaret. 2013. The Mirage of Merit. Australian Feminist Studies 28 (76): 127-143.

Toscano, Alberto. 2011. The Limits of Autonomy: Cognitive Capitalism and University Struggles. In Cognitive Capitalism, Education and Digital Labour, edited by Michael A. Peters and Ergin Bulut, 259-274. New York: Peter Lang.

Wigger, Angela and Hubert Buch-Hansen. 2013. Competition, the Global Crisis, and Alternatives to Neoliberal Capitalism: A Critical Engagement with Anarchism. New Political Science 35 (4): 604-626.

Willmott, Hugh. 1995. Managing the Academics. Commodification and Control in the Development of University Education in the UK. Human Relations 48 (9): 993-1027.

Wilsdon, James, Liz Allen, Eleonora Belfiore, Philip Campbell, Stephen Curry, Steven Hill, Richard Jones, Roger Kain, Simon Kerridge, Mike Thelwall, Jane Tinkler, Ian Viney, Paul Wouters, Jude Hill and Ben Johnson. 2015. The Metric Tide: Report of the Independent 
Review of the Role of Metrics in Research Assessment and Management. HEFCE. Accessed December 15, 2017. http://www.hefce.ac.uk/media/HEFCE,2014/Content/Pubs/Independentresearch/2015/The Metric,Tide/2015 metric tide.pdf

Winn, Joss. 2015. The Co-operative University: Labour, Property and Pedagogy. Power \& Education 7 (1): 29-55.

\section{About the Authors}

Zeena Feldman

Zeena Feldman is Lecturer in Digital Culture in the Department of Digital Humanities, King's College London.

Marisol Sandoval

Marisol Sandoval is Senior Lecturer at the Centre for Culture and Creative Industries, Department of Sociology, City, University of London. 


\title{
In Pursuit of an Alternative Academy: The Case of Kocaeli Academy for Solidarity. Non-peer-reviewed.
}

\author{
Güven Bakırezer*, Derya Keskin Demirer** and Adem Yeșilyurt*** \\ *Kocaeli Academy for Solidarity, Kocaeli, Turkey, guvenbakirezer@gmail.com, \\ www. kocaelidayanisma.org
}

${ }^{* * K o c a e l i}$ Academy for Solidarity, Kocaeli, Turkey, ddkeskin@yahoo.com,
www.kocaelidayanisma.org

***Kocaeli Academy for Solidarity, Kocaeli, Turkey, ademyesilyurt@yahoo.com, www. kocaelidayanisma.org (corresponding author)

\begin{abstract}
After declaring a state of emergency on 20 July, 2016 as a response to the failed coup attempt of 15 July, 2016, the Turkish government launched a nation-wide academic purge, especially targeting the Academics for Peace. This group of academics signed a peace petition in January 2016 to address civilian deaths in the South-Eastern part of the country and to urge the government to take responsibility and restart the peace process. Having the largest number of peace petitioners among Turkey's provincial universities, Kocaeli University was the first to dismiss all 19 of the peace academics from their positions on 1 September, 2016. Already active in defending the universal values of academia in other venues, these dismissed peace academics founded the Kocaeli Academy of Solidarity in pursuit of an alternative academy that aims to bring together university students, NGO members and ordinary citizens in the city in a cooperative understanding of education and research. After weekly seminars over eight months, a summer school of five days, and with applications in for funding its projects, particularly amongst others the School of Life, Kocaeli Academy for Solidarity has a strong determination to demonstrate a new democratic model of education and research.
\end{abstract}

Keywords: Academic Purge, Turkey, Academics for Peace, Alternative Academy, Academic Labour, International Academic Solidarity

\section{Academia in Turkey}

The academic world is globally structured in quite hierarchical ways. Research knowledge is predominantly created in developed countries and transferred to, and implemented in, developing countries. While there are a number of elite institutions that are reasonably well-connected with global research production in the developing countries, unevenness prevails with respect to the majority of provincial universities located in the developing parts of the world. Specifically, research is not always a priority in these provincial universities since these universities, despite constituting the larger chunk of the university population, are primarily expected to provide teaching for the masses.

There have been very painful consequences arising from the publishing pressure in academia that have accelerated in the neoliberal phase of capitalism, particularly in the provincial areas of developing countries. Academics in most Turkish universities are overwhelmed by the heavy teaching load resulting from the excessive numbers of students due to the large young population yet insufficient funds for educa- 
tion. Nonetheless, universities and scholars are forced to publish because of the ever-increasing competition arising from the marketization of metrics-driven higher education. Academics find themselves in a conflicting position in having to choose between spending all of their time in maintaining the quality of their teaching or allocating time for publication and, as a consequence, not putting enough time into teaching, leading to decreased teaching quality. Differences in sizes and resources, as well as traditions, divide academia in Turkey into various types, thus creating disparities both at the national and university level in terms of student-faculty ratio, research opportunities, and promotion practices. In this context, this commentary will concentrate on the case of the Academics for Peace signatories at Kocaeli University and their following struggle in establishing the Kocaeli Academy for Solidarity.

\section{Kocaeli University}

Kocaeli University was founded in 1992 in Izmit, Kocaeli, about 100 kilometres east of Istanbul, the largest city in the country. The student population is over 81,000, with 74,000 at undergraduate and 7,000 at graduate level. At the same time, it is one of the worst with respect to the scholar-student ratio. The university's educational program has mostly focused on the training of a qualified labour force for industry since the university is located in Turkey's largest industrial area. While the School of Engineering accommodates about 11,000 students, nearly half of the undergraduate students (about 36,000) are enrolled in two-year vocational schools in order to find intermediary positions in the industrial sector. The School of Medicine has a dominant position at the university expressed by the fact that the rectors, except the first one, have been traditionally elected from among the medical faculty members. The Medical School's primary concern is to provide health services at the regional scale rather than high quality medical education and research. While the School of Theology was established in 2015, despite the arguable need for it, the long-awaited Sociology Department is yet to be founded, although academics with PhDs in sociology are already offering sociology courses in various departments of the university. Being one of the provincial universities, Kocaeli bears all the negative characteristics of the Turkish academia, while inappropriately being open to illiberal interventions by the political power.

These examples with respect to inequalities and unevenness underpin the mindset of the university administration and the broader mentality towards higher education institutions from the perspective of those in power. It can hardly be claimed that universities in Turkey have ever enjoyed academic autonomy, but this situation has worsened since 2002 under the regime of the Justice and Development Party (AKP). With the changes introduced in the administration of universities under the state of emergency, the President of the country is now able to directly appoint university rectors, who in turn appoint the deans, who in turn appoint department heads. These changes reflect the shift towards a higher education system in which universities appoint academics who are ideologically affiliated with the government rather than choosing people based on merit. 


\section{3. "Nasıl Bir Üniversite? (NBU)" Initiative at Kocaeli University1}

Although Kocaeli University was founded mostly with somewhat left-oriented scholars, this component has depreciated in the last 15 years. NBU initiative was founded by about 50 social democratic and socialist academics working at Kocaeli University to work against the marketization of higher education and the deterioration of scholarly autonomy at universities. In their manifesto, NBU members defended academic freedom, research, democratic participation, merit-based promotion and the financing of universities through the national budget as opposed to private sector involvement. This initiative has been effective particularly in the presidential elections at the University, as well as organizing national and local actions. Its candidate for University President succeeded in getting one quarter of the votes in the last election in 2014, though losing against the current rector who had been openly supported by the country's President. ${ }^{2}$ On several occasions, both the university and the city administration have been hostile to the members of the group because of their critical views and political stance against university policies as well as AKP politics. For example, one of the NBU members was sued by the AKP-affiliated mayor of Kocaeli, mainly because this member's academic research revealed the severe environmental and social costs of industrial air pollution in the region. Another member was nominated as the oppositional Peoples' Democratic Party (HDP) candidate for the mayorship of the metropolitan municipality at the 2014 local elections, demonstrating the group's dissident position and their work for the common good.

\section{Education and Science Workers Union at Kocaeli University}

The Education and Science Workers Union (Eğitim-Sen) became the representative of all staff with the largest number of members at the university in 2015. In addition, it maintained the necessary number of members to become a separate branch at the university mostly due to the efforts of the NBU members. However, this picture changed dramatically after the peace petition became public in January 2016. EğitimSen members were forced to resign from the union or gradually chose to leave it, because of the detainment of the peace petitioners and the dismissal of 19 peace academics from Kocaeli University in September 2016, most of whom were EğitimSen members, while the rest belonged to the Health and Social Care Workers Union (SES). Both Eğitim-Sen and SES belong to the Confederation of Public Workers Union (KESK), known for its social-democratic/socialist politics with regard to labour as distinct from other pro-government unions.

\section{The Peace Petition and Academics for Peace}

In January 2016, 2,212 scholars from Turkey and around the world signed a petition titled "We will not be a party to this crime," also known as the peace petition ${ }^{3}$. The peace petition, initially signed by 1,128 academics calling for an end to the civil

${ }^{1}$ It roughly means "What kind of university?" in Turkish and NBU is its abbreviation. This initiative was based on a desire for a different type of university that defends the autonomy of universities against the marketization of higher education.

${ }^{2}$ It was literally the last election as the elections for university rectors were abolished by a governmental decree no. 676 on October 29, 2016 under conditions of the state of emergency. According to the new regulation, the President of the Country will appoint the new rectors for universities.

${ }^{3}$ For the full text of the peace petition in English and other languages, see:

https://barisicinakademisyenler.net/node/63 
deaths in the South-Eastern part of the country, drew a severe reaction from President Erdoğan, because it put the onus on the State as responsible for restarting the peace process in the country. The President vehemently criticized the peace academics after the peace petition had become public on 11 January, 2016. In a public statement following the petition, Erdoğan stated; "These [academics] are tyrants, despicable people, because those who are with tyrants are also tyrants themselves [...] I call on all judicial authorities and university administrations as their duty to punish these acts against our Constitution and laws [...]"4 Since then the signatories ("Academics for Peace") have been subject to heavy pressure and persecution. Hundreds of them have faced criminal and disciplinary investigations, custody, imprisonment, or violent threats. ${ }^{5}$

\section{The 15 July Coup Attempt and the State of Emergency}

The Turkish government declared a state of emergency on 20 July, 2016 in the aftermath of the 15 July coup attempt, in the course of which the democratic opposition, though having nothing to do with the coup, was suppressed. The co-presidents and some other parliamentary members of the HDP and hundreds of journalists were arrested, many radio and TV channels were closed down, and the activities of many NGOs were suspended. Since then the cabinet has passed successive decrees and dismissed almost 150,000 public servants as of July 2017 , claiming that they were affiliated with, or connected to "terrorist" organizations. The list included faculty members of public universities who signed the peace petition. The number of peace academics dismissed from public service reached about 400 between September 2016 and April 2017. Many others were forced to resign or leave the country. In addition, the passports of the dismissed academics were revoked. The state of emergency provided the government with the pretext to launch an academic purge based on a political cleansing of critical thinkers at universities. The size of the academic purge has frequently caused references analogous to the academic purge of the 1930's in Nazi Germany. ${ }^{6}$

Among the provincial universities, Kocaeli University had the largest number of peace petitioners, and was the first to dismiss all 19 of the peace academics ance as a result of the first emergency decree on 1 September, 2016, decree no. 672. In fact, the signatories at Kocaeli University were the first to be detained by the counterterror police on 15 January, 2016 just a few days after the peace petition had become public and president Erdoğan had targeted the peace petitioners in his speech. The reaction from the Kocaeli University administration was so rapid, mainly because such an opposition could not be tolerated in the provincial areas and it was easier to intervene in provincial universities. Almost all the signatories were members of the NBU and therefore were already "notorious" for their critical views, thereby accelerating the investigation process and the final dismissal from their positions. However, for the very same reason, their supporters at the university, and in the city of Kocaeli in

${ }^{4}$ http://www.hurriyet.com.tr/erdogandan-akademisyenler-bildirisine-sert-sozler-40040876

${ }^{5}$ For an updated list of the rights violations against Academics for Peace, see: https://barisicinakademisyenler.net/node/314

${ }^{6}$ For two different examples of such a reference respectively from a foreign minister and from a scholar, see:

a. https://apnews.com/7e47b81fa2db4eeca77bf6de91cfd148/luxembourg-fm-turkishcrackdown-reminiscent-nazi-methods

b. http://www.birgun.net/haber-detay/nazilerden-kacan-akademisyenleri-arastiran-vialonturkiye-deki-ihraclari-degerlendirdi-147458.html 
general, played a significant role in organizing against their detainment on 15 January, 2016 and in obtaining their release in the late hours of the same day.

\section{Kocaeli Academy for Solidarity}

The academics who were dismissed from their positions at Kocaeli University left the university with the slogan: "We will return! We are not leaving our students and the city". This declaration had paved the way for the foundation of the "Kocaeli Academy for Solidarity" (KODA) ${ }^{7}$ which was launched on 28 September, 2016 with a big crowd including academics from other universities from around the country as well as from abroad.

Kocaeli Academy for Solidarity was established on three bases; legal struggle against the related investigations and dismissals from academic positions; political struggle against the Council for Higher Education of Turkey (YÖK) and the political power; and finally, academic struggle to establish an alternative venue for education and academic research.

In terms of our legal battle, we have made applications to every possible court within the domestic law, while also applying to the European Court of Human Rights. We have been pursuing our political struggle in different forms. Members of the Academy in Kocaeli are also active members of the Kocaeli Democracy Initiative. In addition, one of the members is co-chair of the Peoples' Democratic Congress (HDK), whilst another is the general coordinator for the Confederation of Progressive Trade Unions of Turkey (DiSK). One of the members of KODA, who is a medical doctor, is also a board member of the Human Rights Foundation of Turkey (TiHV), while another takes part in the activities of Doctors Without Borders Turkey Branch.

Yet, our academic labour has become more important as it appears that we shall not be able to return quickly to academia. We have been trying to put into practice our ideals as academics within the Kocaeli Academy for Solidarity, something that we could not have done in the established academy. We have offered weekly seminars that are free and open to the public since October 2016. These continued until the end of the semester at the Eğitim-Sen conference hall in the city centre with an audience of around 100. In these seminars, scholars and students from various disciplines and members of the public initiated interdisciplinary discussions that removed the boundaries between artificially separated disciplines as well as between academics and the public.

The KODA activities seem to have encouraged students at Kocaeli University to establish their own venue for education which they have named the Young Academy. The students have been in contact with the KODA members from the beginning of this process asking their advice. Once established, the Young Academy attracted more students from all walks of life in addition to those who had been following KODA seminars. Since the weekly seminars were presented by only one academic every week, the students demanded classes from dismissed academics on a more regular basis in the form of reading groups which, in turn, gave way to the organization of several reading groups such as Gender, LGBTI and Queer Readings; Symbolic Politics; Philosophy of Liberty; Right to the City; and Labor History; all this within a few months of the Young Academy's start. The reading groups used several coffee shops for their class gatherings near to the Eğitim-Sen Kocaeli Branch where KODA carried out its weekly seminars and other meetings.

\footnotetext{
${ }^{7}$ For more information, see: $\underline{w w w . k o c a e l i d a y a n i s m a . o r g}$
} 
Following the end of the seminar program and the semester for the Kocaeli University students, we organized a summer school between 10 and 15 June, 2017, thanks to the financial resources provided by a few supporters. The school had more than 40 participants consisting mainly of Kocaeli University students both at undergraduate and graduate level, as well as some others from the Kocaeli public. One of the most important outcomes of the summer school was the ability to have students from different backgrounds and political stands working together in an academic and democratic setting. The students expressed their appreciation of this atmosphere since they could discuss any topics without pressure.

We have already applied for research grants in order to fund our research projects in the fields of democracy, human rights, urban studies and environmental protection, equal citizenship, and gender equality. Moreover, we have planned a two-year educational project under the title "The School of Life" for which we have applied for funding that has passed the first stage. This "alternative school" plans to be free and open to the public. Although it only consists of elective courses in conjunction with different disciplines, it is still based on meeting certain requirements for completion. One of the main aims of the program is to break down the hierarchical structure of the established academy and the problematic character of faculty-student relations. The general aim is to sustain education and research not only by KODA academics, but also with students, researchers, and other academics in the city and across the country.

Because of the administrative obstacles existing under the state of emergency, KODA has not been legally established yet, but it has continued its de facto institutionalization. KODA aims to continue its activities and survive independently of the near and far future, even if the members will win their legal battle and return to their positions at the university. In addition, KODA members aim to continue their struggle against the established academy under an umbrella organization both in and outside of the country, together with other alternative academy initiatives and solidarities. Mainly because they are aware of the fact that their imagined academy could only be achieved through coordination and solidarity with a nationwide/global network.

Can KODA succeed? It seems that the overall success of KODA depends on its ability to become a local part of a more general organization for an alternative academy. A number of objective conditions for the realization of this end exist: in particular, local and national connections, public support, the state of affairs within the established academia, as well as the awareness of the fact that nothing will ever be the same at these universities even if all dismissed academics were to return to their positions one way or another. Such an alternative academy can become a locus of power to transform society but can only succeed if it is capable of creating a realistic alternative against the marketized educational system.

Maintaining the quality of educational and research activities is important and can only be achieved through equality in obtaining resources and eliminating academic inequalities at the national and international level. It is essential that research activities provide ways to find solutions to the vital problems of the majority and poor segments of society. Certification of educational activities is also a necessity within existing market conditions in order to provide legitimacy when students require such certification. Still, the question of finance remains as the elephant in the room. In this respect, an alternative academic organization can only exist with the support of civil and democratic mass organizations at the national and international level. KODA members are determined to overcome these challenges and are committed to set an 
example with the support of those around the world who share the same ideals related to education, research and academic labor.

\section{About the Authors}

\section{Güven Bakırezer}

received his $\mathrm{PhD}$ from Boğaziçi University, Turkey, in 2001 with a dissertation entitled "The Turkish Liberalism and the Social Question, 1908-1945". He is the co-editor of Trabzon'u Anlamak (Understanding Trabzon) (2009). He worked in the department of Political Science and Public Administration at Kocaeli University, Turkey, between 2003 and 2016. He was dismissed by a governmental decree for his signature on the so-called "peace petition". He is now a member of the Kocaeli Academy for Solidarity. His current project is an inquiry into the moral and political conditions of living together with differences, with a special interest in Turkish modernist Islamism.

\section{Derya Keskin Demirer}

received her PhD in Development Studies from Marmara University in Istanbul, Turkey, and an MA from the Ohio State University in Columbus, USA. She worked as an assistant professor of Labor Sociology in the Department of Labor Economics and Industrial Relations at Kocaeli University, Turkey, from January 2012 to September 2016. She was dismissed from her position through a governmental decree issued under the state of emergency for signing a petition titled "We will not be a party to this crime," also known as the peace petition which was a call directed to the State to end the civil deaths in the South-Eastern part of the country and to restart the peace process. Her work has been published in journals related to education, labour and the Middle East. Her research interests include migration, women's labour, gender and social policy, religion and women, in addition to education. She continues her work within the Kocaeli Academy for Solidarity as the founding member of the academy with the other eace academics also dismissed from Kocaeli University for the same reason.

\section{Adem Yeşilyurt}

is a PhD Candidate in the Department of Political Science and Public Administration, Middle East Technical University (METU), Ankara, Turkey. He received his MS degree in 2014 from the same department with his thesis "The Role of Reporters in Corporate Media: An Inquiry into the Labor Process of Reporters in Turkey". His research interests include digital labour, political economy of the media, cinema, and social theory. His $\mathrm{PhD}$ research concerns the question of "free-time" in modern capitalism with respect to technology, organizations and working relations. He worked as a research assistant at METU between 2011 and 2014 and then at Kocaeli University until he was dismissed by a governmental decree of September 2016, because of the "peace petition" that he signed. Since then he has been working as the coordinator of the Kocaeli Academy for Solidarity. 